\title{
Bandgap Engineering in $\pi$-Extended Pyrroles. A Modular Approach to Electron-Deficient Chromophores with Multi-Redox Activity
}

\author{
Supporting Information \\ by Halina Zhylitskaya, ${ }^{\dagger}$ Joanna Cybińska, ${ }^{\ddagger \ddagger}$ Piotr Chmielewski, ${ }^{+}$Tadeusz Lis, ${ }^{\dagger}$ \\ and Marcin Stępien ${ }^{+*}$ \\ ${ }^{+}$Wydział Chemii, Uniwersytet Wrocławski, ul. F. Joliot-Curie 14, 50-383 Wrocław, Poland \\ ${ }^{\ddagger}$ Wrocławskie Centrum Badań EIT+, ul. Stabłowicka 147, 54-066 Wrocław, Poland \\ *marcin.stepien@chem.uni.wroc.pl
}

\section{Table of Contents}

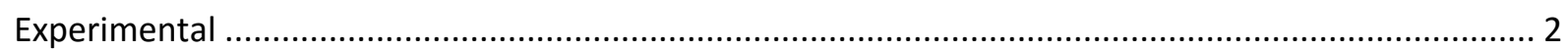

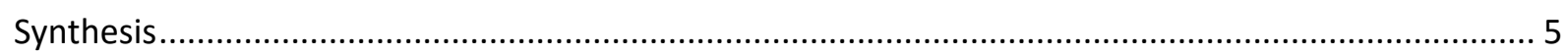

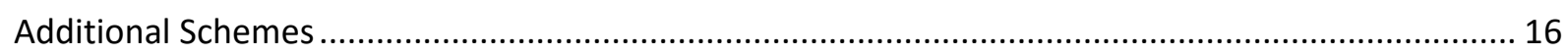

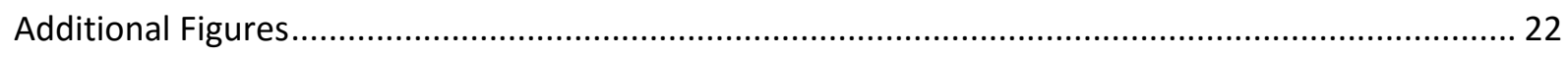

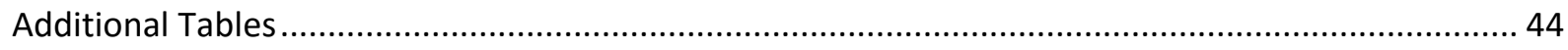

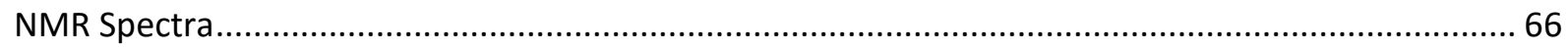

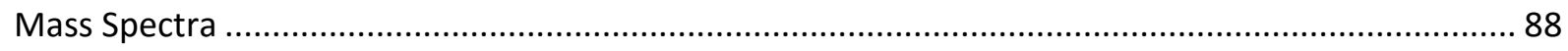

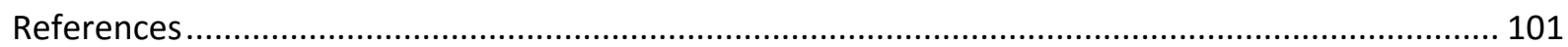


Experimental 
General. Tetrahydrofuran and $\mathrm{N}, \mathrm{N}$-dimethylformamide were dried using a commercial solvent purification system. Dichloromethane and chlorobenzene were distilled from calcium hydride when used as reaction solvents. All other solvents and reagents were used as received. Compound S1 is commercially available and was used as received. ${ }^{1} \mathrm{H}$ NMR spectra were recorded on high-field spectrometers $\left({ }^{1} \mathrm{H}\right.$ frequency 500.13 or $\left.600.13 \mathrm{MHz}\right)$, equipped with broadband inverse or conventional gradient probeheads. Spectra were referenced to the residual solvent signals (chloroform- $d, 7.24 \mathrm{ppm}, \mathrm{N}, \mathrm{N}$-dimethylformamide- $d_{6}, 2.49 \mathrm{ppm}$ ). Two-dimensional NMR spectra were recorded with 2048 data points in the $t_{2}$ domain and up to 2048 points in the $t_{1}$ domain, with a $1 \mathrm{~s}$ recovery delay. All 2D spectra were recorded with gradient selection, with the exception of NOESY and ROESY. NOESY mixing time and ROESY spinlock time were $500 \mathrm{~ms}$ and $300 \mathrm{~ms}$, respectively. ${ }^{13} \mathrm{C}$ NMR spectra were recorded with ${ }^{1} \mathrm{H}$ broadband decoupling and referenced to solvent signals $\left({ }^{13} \mathrm{CDCl}_{3}, 77.0 \mathrm{ppm},\left({ }^{13} \mathrm{CD}_{3}\right)_{2} \mathrm{SO}, 49.5 \mathrm{ppm}\right)$. High resolution mass spectra were recorded using electrospray or MALDI ionization in the positive mode. Electrochemical measurements (THF, $0.1 \mathrm{M}\left[\mathrm{NBu}_{4}\right]\left[\mathrm{BF}_{4}\right], 293 \mathrm{~K}$ ) were performed on an EA9C Multifunctional Electrochemical Analyzer using a glassy-carbon working electrode, platinum wire as the auxiliary electrode, and silver wire as a reference electrode. The voltammograms were referenced against the half-wave potential of $\mathrm{Fc}^{+} / \mathrm{Fc}$.

Reduction of compound 11-Zn. Tetrahydrofuran was deoxygenated by freeze-pump-thaw cycles and stored for $24 \mathrm{~h}$ in an inert-atmosphere glove box over fresh sodium pieces before use. All manupulations were performed in the glove box. Sodium anthracenide (10 mM in THF) was prepared by stirring of anthracene dried under high vacuum $(35.6 \mathrm{mg}, 0.2 \mathrm{mmol})$ with excess sodium metal in tetrahydrofuran $(20 \mathrm{~mL})$ for $24 \mathrm{~h}$. The solution was dark blue. Before use, the spectrophotometer cell was filled with the dry tetrahydrofuran and left with a fresh piece of sodium for $30 \mathrm{~min}$. The cell was then emptied and a solution of compound 11- $\mathrm{Zn}(0.025 \mathrm{mM})$ in tetrahydrofuran was added. The cell was tightly closed with a screw cap fitted with a PTFE-lined septum. The sodium anthracenide solution was taken into a $1 \mathrm{~mL}$ syringe via a needle, and the needle was was pierced through the septum withot adding the reagent. The entire assembly was removed from the glove box. Sodium anthracenide was then titrated into the solution without removing the needle, and the progress of the reaction was monitored spectrophotometrically. The reduction-reoxidation sequence was performed entirely in the glove box. To the solution of 11- $\mathrm{nn}$ placed in the cell was added in one portion sodium anthracenide ( $300 \mu \mathrm{L}, 10 \mathrm{mM}$ ) and the resulting mixture was shaken for $5 \mathrm{~min}$, then diiodine $(4 \mathrm{mg}, 0.015 \mathrm{mmol})$ in in tetrahydrofuran $(0.4 \mathrm{~mL})$ was added in one portion and the mixture was shaken for $10 \mathrm{~min}$. The cell was closed thightly and removed from the glove box, to record the absorption spectrum.

Photoluminescence excitation (PLE) and emission (PL) spectra were taken with the FSL980-sm Fluorescence Spectrometer from Edinburgh Instruments Ltd. A $450 \mathrm{~W}$ Xenon arc lamp (PL and PLE) was used as excitation sources. Emission spectra were corrected for the recording system efficiency and excitation spectra were corrected for the incident light intensity. PLE and PL spectra and QY were measured using a cooled extended-red Hamamatsu photomultiplier operating in a $200-1050 \mathrm{~nm}$ range. Quantum yield measurements were performed by using an Edinburgh Instruments integrating sphere equipped with a small elliptical mirror and a baffle plate for beam steering and shielding against directly detected light. For the measurement, the integrating sphere replaced the standard sample holder inside the sample chamber. Calculations of quantum yields were made using the software provided by Edinburgh Instruments. 
Computational methods. Density functional theory (DFT) calculations were performed using Gaussian 09. ${ }^{1}$ DFT geometry optimizations were carried out in unconstrained $C_{1}$ symmetry, using molecular mechanics or semiempirical models as starting geometries. DFT geometries were refined to meet standard convergence criteria, and the existence of a local minimum was verified by a normal mode frequency calculation. Geometry optimizations, frequency calculations, and thermochemistry calculations were performed using the hybrid functional B3LYP, ${ }^{2-4}$ the $6-31 G(d, p)$ basis set. The PCM solvation ${ }^{5}$ (standard DMSO parameters) was included in the calculations performed for pyrroles. For each pyrrole, 50 electronic transitions were calculated by means of timedependent DFT (TD-DFT), using the above level of theory and the Tamm-Dancoff approximation (TDA). ${ }^{6}$ The same approach was also used for optimizing the S1 excited-state geometries of $\mathbf{2}$ and $\mathbf{3}$. NICS(1) values were calculated using the GIAO formalism. ${ }^{7,8}$

Neutral and charged forms of 10-Zn and 11-Zn were optimized in vacuo at the B3LYP/6-31G(d,p) level of theory. The energies used for computational chemistry calculations consisted of M06- $2 \mathrm{X}^{9} / \mathrm{cc}-$ $\mathrm{VTZ}^{10-12}$ electronic energies obtained in single-point calculations, SMD solvation energies ${ }^{13}$ (THF parameterization) calculated with the $B 3 \operatorname{LYP} / 6-31 \mathrm{G}(\mathrm{d}, \mathrm{p})$ wavefunctions, and $B 3 \operatorname{LYP} / 6-31 \mathrm{G}(\mathrm{d}, \mathrm{p})$ thermal corrections. Absolute redox potentials were then calculated using the standard approach. ${ }^{14}$ Quantitative accuracy could not be achieved in these calculations, apparently because of the limited basis sets used for the description of highly charged species.

Fragment charges in pyrroles and porphyrins were calculated by summing atomic charges obtained using the natural population analysis ${ }^{15}$ (NPA). PCM(DMSO)/B3LYP/6-31G(d,p) was used for pyrroles, and M06-2X/cc-VTZ was used for $[10-Z n]^{n}$ and $[11-Z n]^{n}$.

X-ray crystallography. X-ray quality crystals were grown by slow diffusion of $n$-hexane into a dichloromethane solutions of $11-\mathrm{Zn}$ and $\mathbf{1 1}-\mathrm{H}_{2}$, chloroform solutions of $11-\mathrm{H}_{2}$, by slow evaporation of dichloromethane solution of $\mathbf{2}$ or by slow diffusion of water (from air) into a saturated dimethylsulfoxide solution of $\mathbf{5}$. Diffraction measurements were performed on a k-geometry Ruby PX diffractometer ( $\omega$ scans) with graphite-monochromatized Mo $K_{\alpha}$ radiation. The data were collected at $100 \mathrm{~K}$ and $80 \mathrm{~K}$ respectively, corrected for Lorenz and polarization effects. Data collection, cell refinement, data reduction and analysis were carried out with the Xcalibur PX software, CRYSALIS CCD and CRYSALIS RED, respectively (Oxford Diffraction Ltd., Abignon, England, 2009). An analytical absorption correction was applied with the use of CRYSALIS RED. All structures were solved by direct methods with the SHELXS-97 program and refined using SHELXL- $97^{16}$ with anisotropic thermal parameters for non-H atoms. In the final refinement cycles, all $\mathrm{H}$ atoms were treated as riding atoms in geometrically optimized positions. CCDC Mercury and CrystalExplorer ${ }^{17,18}$ were used for visualization of solvent-accessible surfaces. 
Synthesis 


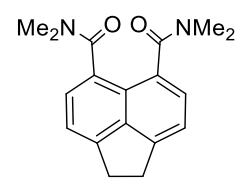

$N^{5}, N^{5}, N^{6}, N^{6}$-Tetramethyl-1,2-dihydroacenaphthylene-5,6-dicarboxamide (S2). Compound S2 was prepared following a literature procedure. ${ }^{19}$ Yield $43 \% .{ }^{1} \mathbf{H}$ NMR $(500 \mathrm{MHz}$, chloroform-d, $300 \mathrm{~K}): \delta$ $7.51\left(2 \mathrm{H}, \mathrm{d}^{3} \mathrm{~J}=7.0 \mathrm{~Hz}\right), 7.44\left(2 \mathrm{H}, \mathrm{d}^{3}{ }^{3} \mathrm{~J}=7.0 \mathrm{~Hz}\right), 3.54(4 \mathrm{H}, \mathrm{s}), 3.22(6 \mathrm{H}, \mathrm{s}), 3.00(6 \mathrm{H}, \mathrm{s}) .{ }^{13} \mathrm{C}$ NMR $(151$ $\mathrm{MHz}$, chloroform-d, $300 \mathrm{~K})$ : $\delta 171.24,147.43,139.64,129.90,127.53,124.81,119.26,39.19,34.82$, 30.13 .

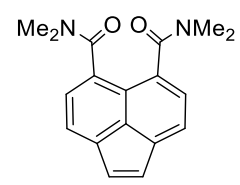

$\boldsymbol{N}^{5}, \boldsymbol{N}^{5}, \boldsymbol{N}^{6}, \boldsymbol{N}^{6}$-Tetramethylacenaphthylene-5,6-dicarboxamide (S3). ${ }^{20}$ Compound $\mathbf{S 2}$ (13.32 g, 44.95 mmol), $N$-bromosuccinimide $(17.60 \mathrm{~g}, 98.88 \mathrm{mmol})$, benzoyl peroxide $(2.17 \mathrm{~g}, 8.99 \mathrm{mmol})$ and chloroform $(300 \mathrm{~mL})$ were placed in a $500 \mathrm{~mL}$ round-bottom flask equipped with magnetic stirring and a reflux condenser and the resulting mixture was refluxed for $2 \mathrm{~h}$. Then the mixture was cooled down to room temperature, washed with saturated aqueous sodium bicarbonate, dried over anhydrous sodium sulfate and evaporated to dryness in vacuum. The resulting yellow solid, zinc powder $(20.60 \mathrm{~g}, 315 \mathrm{mmol})$, and ethanol $(250 \mathrm{~mL})$ were placed in a $500 \mathrm{~mL}$ round-bottom flask equipped with magnetic stirring and a reflux condenser and the suspension was refluxed for $1 \mathrm{~h}$. Then the unreacted zinc was filtered off. The ethanol was evaporated in vacuum and the resulting yellow oil was dissolved in dichloromethane. Water was added to the solution and the resulting white precipitate was filtrated off. The organic phase was washed with brine, dried over anhydrous sodium sulfate and evaporated to dryness in vacuum to give product as yellow solid $(13.10 \mathrm{~g}, 99 \%)$. ${ }^{1} \mathrm{H}$ NMR $(500 \mathrm{MHz}$, chloroform- $d, 300 \mathrm{~K}): \delta 7.76\left(2 \mathrm{H}, \mathrm{d},{ }^{3} \mathrm{~J}=7.0 \mathrm{~Hz}\right), 7.53\left(2 \mathrm{H}, \mathrm{d},{ }^{3} \mathrm{~J}=7.0 \mathrm{~Hz}\right), 7.17(2 \mathrm{H}$, s), $3.24(6 \mathrm{H}, \mathrm{s}), 3.01(6 \mathrm{H}, \mathrm{s}) .{ }^{13} \mathrm{C}$ NMR $(125 \mathrm{MHz}$, chloroform-d, $300 \mathrm{~K}): \delta 170.55,140.56,134.78$, 130.07, 128.89, 126.90, 123.99, 122.14, 39.38, 34.76. HRMS (ESI-TOF): $\mathrm{m} / \mathrm{z}:[\mathrm{M}+\mathrm{Na}]+$ Calcd for $\mathrm{C}_{18} \mathrm{H}_{18} \mathrm{~N}_{2} \mathrm{O}_{2} \mathrm{Na:}$ 317.1260; Found 317.1254.

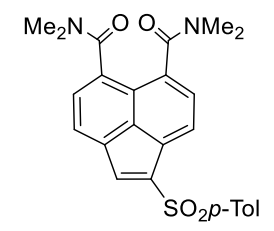

$N^{5}, N^{5}, N^{6}, N^{6}$-Tetramethyl-1-tosylacenaphthylene-5,6-dicarboxamide (S4). Prepared according to a literature procedure. ${ }^{21}$ Finely crushed iodine $(11.39 \mathrm{~g}, 44.87 \mathrm{mmol})$ was added to a biphasic solution of compound S3 (12.75 g, $43.32 \mathrm{mmol})$ and sodium $p$-toluenesulfinate $(12.97 \mathrm{~g}, 72.76 \mathrm{mmol})$ in dichloromethane/water ( $136 \mathrm{~mL}, 1: 1 \mathrm{v} / \mathrm{v}$ ) and then the reaction mixture was stirred vigorously for 17 $\mathrm{h}$ at room temperature. The reaction mixture was diluted with dichloromethane, washed with saturated sodium bicarbonate, an aqueous sodium bisulfate solution (4 wt\%), and finally with brine, dried over anhydrous sodium sulfate and concentrated in vacuum. The resulting foamy yellow residue was dissolved in toluene, treated with 1,8-diazabicyclo[5.4.0]undec-7-ene (DBU, $7.38 \mathrm{~mL}$, $49.38 \mathrm{mmol}$ ) and stirred at room temperature for $1 \mathrm{~h}$. The reaction mixture was filtered; the filtrate was washed with $1 \mathrm{M}$ hydrochloric acid, saturated aqueous sodium bicarbonate and brine, and dried 
over anhydrous sodium sulfate. The solution was concentrated in vacuum and the residue was purified by column chromatography on silica with dichloromethane/methanol (100:2 v/v) as the eluent to give the product as a yellow foam (14.80 g, 76\%). ${ }^{1} \mathrm{H}$ NMR $(500 \mathrm{MHz}$, chloroform-d, $300 \mathrm{~K})$ : $\delta 8.03\left(1 \mathrm{H}, \mathrm{d}^{3} \mathrm{~J}=7.0 \mathrm{~Hz}\right), 7.93(2 \mathrm{H}, \mathrm{m}), 7.85\left(1 \mathrm{H}, \mathrm{d}^{3}{ }^{3} \mathrm{~J}=7.0 \mathrm{~Hz}\right), 7.76(1 \mathrm{H}, \mathrm{s}), 7.44\left(1 \mathrm{H}, \mathrm{d},{ }^{3} J=7.0 \mathrm{~Hz}\right)$, $7.43\left(1 \mathrm{H}, \mathrm{d},{ }^{3} J=7.3 \mathrm{~Hz}\right), 7.29\left(2 \mathrm{H}, \mathrm{d},{ }^{3} J=8.1 \mathrm{~Hz}\right), 3.058(3 \mathrm{H}, \mathrm{s}), 3.056(3 \mathrm{H}, \mathrm{s}), 2.82(3 \mathrm{H}, \mathrm{s}), 2.81(3 \mathrm{H}, \mathrm{s})$, 2.37 (3H, s). ${ }^{13} \mathrm{C}$ NMR (125 MHz, chloroform-d, $300 \mathrm{~K}$ ): $\delta$ 169.60, 169.52, 144.40, 142.06, 138.64, $138.45,136.51,136.03,135.82,134.20,129.96,129.00,128.47,127.57,127.12,125.86,122.70$, 39.28, 39.20, 34.68, 21.56. HRMS (ESI-TOF): $m / z:[\mathrm{M}+\mathrm{H}]+$ Calcd for $\mathrm{C}_{25} \mathrm{H}_{25} \mathrm{~N}_{2} \mathrm{O}_{4} \mathrm{~S}: 440.1530$; Found 449.1542 .

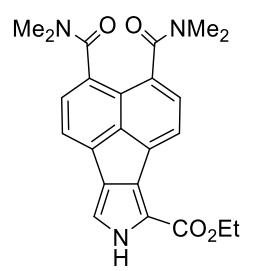

Ethyl 3,4-bis(dimethylcarbamoyl)-8H-acenaphtho[1,2-c]pyrrole-7-carboxylate (S5). A 2 M solution of potassium tert-butoxide in 2-methyltetrahydrofuran $(23.74 \mathrm{~mL}, 47.48 \mathrm{mmol}$ ) was added to a stirred solution of $\mathbf{S 4}(14.20 \mathrm{~g}, 31.66 \mathrm{mmol})$ and ethyl isocyanoacetate $(4.69 \mathrm{~mL}, 40.81 \mathrm{mmol})$ in tetrahydrofuran $(218 \mathrm{~mL})$ at $0{ }^{\circ} \mathrm{C}$ under an argon atmosphere. The resulting mixture was stirred at $0{ }^{\circ} \mathrm{C}$ for $4 \mathrm{~h}$. Then the mixture was diluted with water and extracted with dichloromethane. Organic phases were washed with water and brine and dried over anhydrous sodium sulfate; the solvent was evaporated under reduced pressure to dryness. Ethyl acetate was added to the resulting solid and the resulting mixture was stirred at $80^{\circ} \mathrm{C}$ for $20 \mathrm{~min}$. The mixture was cooled down to room temperature and the insoluble solid was filtered and dried to give the product as a pale yellow solid (9.70 g, 76\%). ${ }^{1} \mathbf{H}$ NMR (500 MHz, chloroform-d, $300 \mathrm{~K}$ ): $\delta 8.96(1 \mathrm{H}, \mathrm{b}), 8.06\left(1 \mathrm{H}, \mathrm{d},{ }^{3} \mathrm{~J}=7.3 \mathrm{~Hz}\right), 7.57$ $\left(1 \mathrm{H}, \mathrm{d},{ }^{3} \mathrm{~J}=7.0 \mathrm{~Hz}\right), 7.45\left(1 \mathrm{H}, \mathrm{d},{ }^{3} \mathrm{~J}=7.3 \mathrm{~Hz}\right), 7.38\left(1 \mathrm{H}, \mathrm{d},{ }^{3} \mathrm{~J}=7.0 \mathrm{~Hz}\right), 7.14\left(1 \mathrm{H},{ }^{3} \mathrm{~J}=2.8 \mathrm{~Hz}\right), 4.48(2 \mathrm{H}, \mathrm{q}$, $\left.{ }^{3} \mathrm{~J}=2.8 \mathrm{~Hz}\right), 3.083(3 \mathrm{H}, \mathrm{s}), 3.080(3 \mathrm{H}, \mathrm{s}), 2.882(3 \mathrm{H}, \mathrm{s}), 2.878(3 \mathrm{H}, \mathrm{s}), 1.50\left(3 \mathrm{H}, \mathrm{t},{ }^{3} \mathrm{~J}=2.8 \mathrm{~Hz}\right) .{ }^{13} \mathrm{C} \mathrm{NMR}$ (151 MHz, chloroform- $d, 300 \mathrm{~K}): \delta$ 170.86, 170.80, 160.92, 137.63, 133.67, 133.38, 133.30, 132.41, 132.25, 129.54, 127.44, 127.08, 124.37, 122.55, 119.20, 116.21, 115.26, 60.88, 39.35, 39.30, 34.81, 34.79, 14.66. HRMS (ESI-TOF): $\mathrm{m} / \mathrm{z}$ : [M + Na]+ Calcd for $\mathrm{C}_{23} \mathrm{H}_{23} \mathrm{~N}_{3} \mathrm{O}_{4} \mathrm{Na}$ : 428.1581; Found 428.1584 .

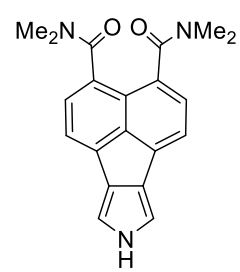

$N^{3}, N^{3}, N^{4}, N^{4}$-Tetramethyl-8H-acenaphtho[1,2-c]pyrrole-3,4-dicarboxamide (2). The mixture of compound S5 (4.00 g, $9.87 \mathrm{mmol})$ and potassium hydroxide $(8.30 \mathrm{~g}, 147.98 \mathrm{mmol})$ in ethylene glycol $\left(100 \mathrm{~mL}\right.$ ) was purged with nitrogen for $10 \mathrm{~min}$, and then stirred on a preheated oil bath at $196{ }^{\circ} \mathrm{C}$ for further $2 \mathrm{~h}$. The mixture was cooled to room temperature, poured into water and extracted with dichloromethane. The organic phase was washed with water and brine, dried over anhydrous sodium sulfate and evaporated under reduced pressure. The residue was purified by column chromatography on silica with dichloromethane/methanol/ $\mathrm{Et}_{3} \mathrm{~N}(100: 2: 0.1 \mathrm{v} / \mathrm{v})$ as the eluent to give the product as a pale yellow solid (3.20 g, 97\%). ${ }^{1} \mathrm{H}$ NMR (600 MHz, DMSO- $\left.d_{6}, 300 \mathrm{~K}\right): \delta 10.98(1 \mathrm{H}, \mathrm{b})$, 
$7.50\left(2 \mathrm{H}, \mathrm{d},{ }^{3} \mathrm{~J}=7.0 \mathrm{~Hz}\right), 7.27\left(2 \mathrm{H}, \mathrm{d},{ }^{3} J=7.0 \mathrm{~Hz}\right), 7.11\left(2 \mathrm{H}, \mathrm{d},{ }^{3} \mathrm{~J}=2.4 \mathrm{~Hz}\right), 2.91(6 \mathrm{H}, \mathrm{s}), 2.78(6 \mathrm{H}, \mathrm{s}) .{ }^{13} \mathrm{C}$ NMR $\left(151 \mathrm{MHz}\right.$, DMSO- $\left.d_{6}, 300 \mathrm{~K}\right): \delta 170.10,137.08,134.78,130.75,126.80,124.54,117.55,112.35$, 38.75, 34.26. HRMS (ESI-TOF): $m / z$ : [M + Na]+ Calcd for $\mathrm{C}_{20} \mathrm{H}_{19} \mathrm{~N}_{3} \mathrm{O}_{2} \mathrm{Na}$ : 356.1369; Found 356.1374. UV-vis (DMSO, $293 \mathrm{~K}) \lambda[\mathrm{nm}]\left(\varepsilon\right.$ in $\left.\mathrm{M}^{-1} \mathrm{~cm}^{-1}\right): 377$ (11 400).

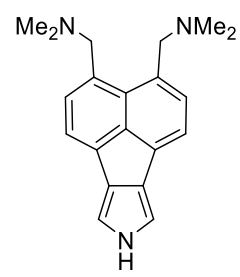

1,1'-(8H-Acenaphtho[1,2-c]pyrrole-3,4-diyl)bis( $N, N$-dimethylmethanamine) (1). Lithium aluminum hydride $(79.09 \mathrm{mg}, 1.98 \mathrm{mmol})$ was added to the stirred solution of compound $2(66.00 \mathrm{mg}, 0.20$ mmol) in tetrahydrofuran $(5 \mathrm{~mL})$ at $0{ }^{\circ} \mathrm{C}$ under an argon atmosphere and the resulting mixture was refluxed for $6 \mathrm{~h}$. The mixture was cooled down to $0{ }^{\circ} \mathrm{C}$ and water $(360 \mu \mathrm{L})$ and $40 \%$ aqueous sodium hydroxide $(360 \mu \mathrm{L})$ were added subsequently. The white precipitate was filtered off, the filtrate was evaporated and the residue was purified by column chromatography on alumina (grade III) with dichloromethane/methanol (100:0.3 v/v) to give the product as a colorless solid (43 mg, $71 \%) .{ }^{1} \mathbf{H}$ NMR $(500 \mathrm{MHz}$, chloroform- $d, 300 \mathrm{~K}): \delta 8.30(1 \mathrm{H}, \mathrm{b}), 7.42\left(2 \mathrm{H}, \mathrm{d},{ }^{3} \mathrm{~J}=7.1 \mathrm{~Hz}\right), 7.32\left(2 \mathrm{H}, \mathrm{d},{ }^{3} \mathrm{~J}=7.1 \mathrm{~Hz}\right)$, $6.88(2 \mathrm{H}, \mathrm{b}), 3.99(4 \mathrm{H}, \mathrm{s}), 2.22(12 \mathrm{H}, \mathrm{s}) .{ }^{13} \mathrm{C}$ NMR $(151 \mathrm{MHz}$, chloroform-d, $300 \mathrm{~K}): \delta 139.78,134.15$, 133.34, 132.57, 130.25, 128.29, 117.77, 110.30, 64.34, 45.38. HRMS (ESI-TOF): $\mathrm{m} / \mathrm{z}:[\mathrm{M}+\mathrm{H}]+$ Calcd for $\mathrm{C}_{20} \mathrm{H}_{24} \mathrm{~N}_{3}$ : 306.1965; Found 306.1968. UV-vis (DMSO, $\left.293 \mathrm{~K}\right) \lambda[\mathrm{nm}]\left(\varepsilon\right.$ in $\left.\mathrm{M}^{-1} \mathrm{~cm}^{-1}\right): 367(10500)$.

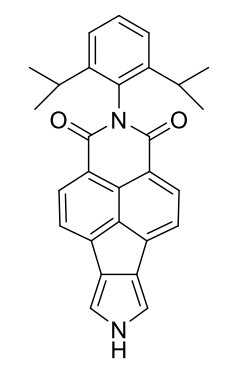

2-(2,6-Diisopropylphenyl)pyrrolo[3',4':2,3]indeno[6,7,1-def]isoquinoline-1,3(2H,7H)-dione (4). The mixture of compound $2(0.70 \mathrm{~g}, 2.10 \mathrm{mmol})$ and 2,6-diisopropylaniline $(1.22 \mathrm{~mL}, 6.30 \mathrm{mmol})$ in glacial acetic acid $(6 \mathrm{~mL})$ was placed in a pressure tube, purged with nitrogen for $10 \mathrm{~min}$, sealed, and then heated for $17 \mathrm{~h}$ at $160^{\circ} \mathrm{C}$. Then the mixture was cooled down to room temperature and diluted with water. The precipitate was filtered, washed with water and dried. Methanol was added to the resulting solid and the mixture was stirred at $60^{\circ} \mathrm{C}$ for $10 \mathrm{~min}$ and then cooled down to room temperature. The insoluble material was filtered off and dried in vacuum to give the product as an orange powder (590 mg, 67\%). ${ }^{1} \mathrm{H}$ NMR $\left(600 \mathrm{MHz}, \mathrm{DMSO}-\mathrm{d}_{6}, 300 \mathrm{~K}\right): \delta 11.23(1 \mathrm{H}, \mathrm{b}), 8.29\left(2 \mathrm{H}, \mathrm{d},{ }^{3} \mathrm{~J}=\right.$ $7.3 \mathrm{~Hz}), 7.69\left(2 \mathrm{H}, \mathrm{d},{ }^{3} \mathrm{~J}=7.4 \mathrm{~Hz}\right), 7.40\left(1 \mathrm{H}, \mathrm{t},{ }^{3} \mathrm{~J}=7.8 \mathrm{~Hz}\right), 7.29\left(2 \mathrm{H}, \mathrm{d},{ }^{3} J=7.8 \mathrm{~Hz}\right), 7.27\left(2 \mathrm{H}, \mathrm{d},{ }^{3} J=2.5\right.$ $\mathrm{Hz}), 2.68\left(2 \mathrm{H}\right.$, sept, $\left.{ }^{3} \mathrm{~J}=6.8 \mathrm{~Hz}\right), 1.04\left(12 \mathrm{H}, \mathrm{d},{ }^{3} \mathrm{~J}=6.8 \mathrm{~Hz}\right) .{ }^{13} \mathrm{C}$ NMR $\left(151 \mathrm{MHz}\right.$, DMSO- $\left.d_{6}, 300 \mathrm{~K}\right): \delta$ $163.56,145.52,140.40,135.88,132.88,131.55,128.71,127.44,125.96,123.41,119.19,118.15$, 116.59, 28.39, 23.56. HRMS (ESI-TOF): $\mathrm{m} / \mathrm{z}$ : $[\mathrm{M}+\mathrm{H}]+$ Calcd for $\mathrm{C}_{28} \mathrm{H}_{25} \mathrm{~N}_{2} \mathrm{O}_{2}$ : 421.1911; Found 421.1908. UV-vis (DMSO, $293 \mathrm{~K}) \lambda[\mathrm{nm}]\left(\varepsilon\right.$ in $\left.\mathrm{M}^{-1} \mathrm{~cm}^{-1}\right): 445$ (16 300). 


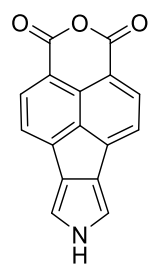

1H-Pyrano[3',4',5':5,6]acenaphtho[1,2-c]pyrrole-1,3(7H)-dione (5). A suspension of compound 2 $(1.00 \mathrm{~g}, 3.00 \mathrm{mmol})$ in glacial acetic acid $(10 \mathrm{~mL})$ was placed in a pressure tube, purged with nitrogen for $10 \mathrm{~min}$, sealed, and then heated for $17 \mathrm{~h}$ at $170{ }^{\circ} \mathrm{C}$. Then the mixture was cooled down to room temperature and diluted with water. The precipitate was filtered, washed with water and dichloromethane, and dried in vacuum to give the product as a pale yellow powder (640 $\mathrm{mg}, 82 \%) .{ }^{1} \mathbf{H}$ NMR $\left(600 \mathrm{MHz}, \mathrm{DMSO}-d_{6}, 300 \mathrm{~K}\right): \delta 11.30(1 \mathrm{H}, \mathrm{b}), 8.30\left(2 \mathrm{H}, \mathrm{d},{ }^{3} \mathrm{~J}=7.3 \mathrm{~Hz}\right), 7.70\left(2 \mathrm{H}, \mathrm{d},{ }^{3} \mathrm{~J}=7.3 \mathrm{~Hz}\right)$, $7.29\left(2 \mathrm{H}, \mathrm{d},{ }^{3} \mathrm{~J}=2.6 \mathrm{~Hz}\right) .{ }^{13} \mathrm{C}$ NMR $\left(151 \mathrm{MHz}\right.$, DMSO-d $\left.d_{6}, 300 \mathrm{~K}\right): \delta 160.47,140.92,135.56,134.31$, $127.74,127.31,119.29,117.03,114.95$. HRMS (ESI-TOF): $\mathrm{m} / \mathrm{z}:[\mathrm{M}+\mathrm{Na}]+$ Calcd for $\mathrm{C}_{16} \mathrm{H}_{7} \mathrm{NO}_{3} \mathrm{Na}$ : 284.0318; Found 284.0316. UV-vis (DMSO, $293 \mathrm{~K}) \lambda[\mathrm{nm}]\left(\varepsilon\right.$ in $\left.\mathrm{M}^{-1} \mathrm{~cm}^{-1}\right): 445$ (15 900).

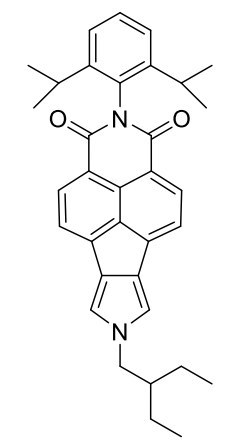

2-(2,6-Diisopropylphenyl)-7-(2-ethylbutyl)pyrrolo[3',4':2,3]indeno[6,7,1-def]isoquinoline-

$\mathbf{1 , 3}(\mathbf{2 H}, \mathbf{7 H})$-dione $\left(\mathbf{4}^{\prime}\right)$. Sodium hydride (60\% suspension in mineral oil) $(5.71 \mathrm{mg}, 0.14 \mathrm{mmol})$ was added to the solution of compound 4 (30 mg, $0.07 \mathrm{mmol})$ in $N, N$-dimethylformamide $(0.5 \mathrm{~mL})$ at $0{ }^{\circ} \mathrm{C}$ and stirred for $20 \mathrm{~min}$. Then 3-(bromomethyl)pentane $(20.59 \mu \mathrm{L}, 0.143 \mathrm{mmol}$ ) was added and the resulting mixture was stirred at room temperature for $2 \mathrm{~h}$. The mixture was then diluted with water and extracted with diethyl ether; the organic phase was washed with brine and dried over anhydrous sodium sulfate. The solvent was evaporated and the residue was purified by column chromatography on silica with dichloromethane/hexane $(1: 1 \mathrm{v} / \mathrm{v})$ as the eluant to give the product as an orange powder (36 mg, 86\%). ${ }^{1} \mathrm{H}$ NMR (500 MHz, chloroform-d, $\left.300 \mathrm{~K}\right): \delta 8.37\left(2 \mathrm{H}, \mathrm{d},{ }^{3} \mathrm{~J}=7.3 \mathrm{~Hz}\right), 7.54(2 \mathrm{H}, \mathrm{d}$, $\left.{ }^{3} J=7.3 \mathrm{~Hz}\right), 7.42\left(1 \mathrm{H}, \mathrm{t}^{3} \mathrm{~J}=7.6 \mathrm{~Hz}\right), 7.29\left(2 \mathrm{H}, \mathrm{d}^{3}{ }^{3}=7.6 \mathrm{~Hz}\right), 6.85(2 \mathrm{H}, \mathrm{s}), 3.78\left(2 \mathrm{H}, \mathrm{d}^{3}{ }^{3} J=7.1 \mathrm{~Hz}\right), 2.79$ $\left(2 \mathrm{H}, \operatorname{sept}^{3} \mathrm{~J}=6.8 \mathrm{~Hz}\right), 1.72\left(1 \mathrm{H}, \operatorname{sept}^{3} \mathrm{~J}=6.4 \mathrm{~Hz}\right), 1.38(4 \mathrm{H}, \mathrm{m}), 1.14\left(12 \mathrm{H}, \mathrm{d},{ }^{3} \mathrm{~J}=6.8 \mathrm{~Hz}\right), 0.94\left(6 \mathrm{H}, \mathrm{t},{ }^{3} \mathrm{~J}\right.$ $=7.4 \mathrm{~Hz}$ ). ${ }^{13} \mathrm{C}$ NMR $(125 \mathrm{MHz}$, chloroform-d, $300 \mathrm{~K}): \delta$ 164.32, 145.89, 140.34, 136.22, 133.00, 131.50, 129.16, 128.52, 126.72, 123.79, 119.55, 118.94, 118.10, 53.70, 42.64, 29.01, 23.99, 23.31, 10.72. HRMS (ESI-TOF): $m / z:[M+\mathrm{H}]+$ Calcd for $\mathrm{C}_{34} \mathrm{H}_{37} \mathrm{~N}_{2} \mathrm{O}_{2}$ : 505.2850; Found 505.2851. UV-vis (DMSO, 293 K) $\lambda[\mathrm{nm}]\left(\varepsilon\right.$ in $\left.\mathrm{M}^{-1} \mathrm{~cm}^{-1}\right): 439$ (14 800). 


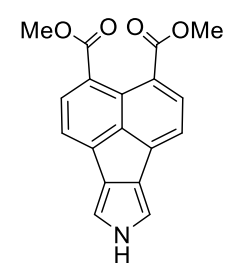

Dimethyl $8 \mathrm{H}$-acenaphtho[1,2-c]pyrrole-3,4-dicarboxylate (3). 1,8-Diazabicyclo[5.4.0]undec-7-ene (119.07 $\mu \mathrm{L}, 0.80 \mathrm{mmol}$ ) was added to the degassed solution of compound 5 (104 $\mathrm{mg}, 0.40 \mathrm{mmol}$ ) and methyl iodide $(148.70 \mu \mathrm{L}, 2.39 \mathrm{mmol})$ in methanol $(1 \mathrm{~mL})$, and the resulting solution was heated under nitrogen atmosphere at $70^{\circ} \mathrm{C}$ for $4 \mathrm{~h}$. The mixture was cooled down, diluted with dichloromethane, washed subsequently with $3 \%$ aqueous hydrochloric acid, a saturated solution of sodium bicarbonate and brine, and dried over anhydrous sodium sulfate. The solvent was evaporated and the residue was purified by column chromatography on silica with dichloromethane/methanol/triethylamine $(100: 1: 0.1 \mathrm{v} / \mathrm{v} / \mathrm{v})$ to give the product as yellow solid (122 $\mathrm{mg}, 82 \%) .{ }^{1} \mathrm{H}$ NMR $\left(600 \mathrm{MHz}, \mathrm{DMSO}-\mathrm{d}_{6}, 300 \mathrm{~K}\right): \delta 11.13(1 \mathrm{H}, \mathrm{b}), 7.85\left(2 \mathrm{H}, \mathrm{d},{ }^{3} \mathrm{~J}=7.3 \mathrm{~Hz}\right), 7.56\left(2 \mathrm{H}, \mathrm{d},{ }^{3} \mathrm{~J}\right.$ $=7.3 \mathrm{~Hz}), 7.17\left(2 \mathrm{H}, \mathrm{d},{ }^{3} \mathrm{~J}=2.5 \mathrm{~Hz}\right), 3.78(6 \mathrm{H}, \mathrm{s}) .{ }^{13} \mathrm{C}$ NMR $\left(151 \mathrm{MHz}\right.$, DMSO-d $\left.d_{6}, 300 \mathrm{~K}\right): \delta 168.25$, $137.79,137.63,131.95,126.70,125.69,125.21,117.49,113.95,51.77$. HRMS (ESI-TOF): $\mathrm{m} / \mathrm{z}:[\mathrm{M}+$ $\mathrm{Na}$ ]+ Calcd for $\mathrm{C}_{18} \mathrm{H}_{13} \mathrm{NO}_{4} \mathrm{Na:}$ 330.0737; Found 330.0741. UV-vis (DMSO, $\left.293 \mathrm{~K}\right) \lambda[\mathrm{nm}]\left(\varepsilon\right.$ in $\left.\mathrm{M}^{-1} \mathrm{~cm}^{-1}\right)$ : 393 (11 100).

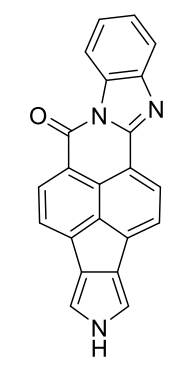

Benzo[4,5]imidazo[2,1-a]pyrrolo[3',4':2,3]indeno[6,7,1-def]isoquinolin-6(2H)-one (6). A suspension of compound 5 (50 mg, $0.191 \mathrm{mmol}$ ), o-phenylenediamine $(64.68 \mathrm{mg}, 0.598 \mathrm{mmol}$ ) and anhydrous zinc(II) chloride ( $19.57 \mathrm{mg}, 0.144 \mathrm{mmol}$ ) in quinoline $(0.5 \mathrm{~mL})$ was purged with nitrogen for $5 \mathrm{~min}$ and then heated at $230^{\circ} \mathrm{C}$ for $3 \mathrm{~h}$. The reaction mixture was cooled down and poured to aqueous $1 \mathrm{~N}$ hydrochloric acid; the precipitate was centrifuged, washed with water until neutral, washed with methanol and dried, to give product as dark brown powder (55 mg, 86\%). ${ }^{1} \mathrm{H}$ NMR (600 MHz, DMSO$\left.d_{6}, 300 \mathrm{~K}\right): \delta 11.11(1 \mathrm{H}, \mathrm{b}), 8.38(3 \mathrm{H}, \mathrm{m}), 7.77(1 \mathrm{H}, \mathrm{m}), 7.68\left(1 \mathrm{H}, \mathrm{d},{ }^{3} \mathrm{~J}=7.3 \mathrm{~Hz}\right), 7.63\left(1 \mathrm{H}, \mathrm{d},{ }^{3} \mathrm{~J}=7.3 \mathrm{~Hz}\right)$, $7.41(2 \mathrm{H}, \mathrm{m}), 7.20\left(1 \mathrm{H}, \mathrm{d},{ }^{3} \mathrm{~J}=2.5 \mathrm{~Hz}\right), 7.15\left(1 \mathrm{H}, \mathrm{d},{ }^{3} \mathrm{~J}=2.5 \mathrm{~Hz}\right) .{ }^{13} \mathrm{C} \mathrm{NMR}\left(151 \mathrm{MHz}, \mathrm{DMSO}-d_{6}, 300 \mathrm{~K}\right): \delta$ $160.29,149.48,143.58,141.33,137.75,136.39,132.86,132.03,127.98,127.84,127.16,125.25$, $125.11,124.87,119.58,119.11,118.97,117.14,116.54,115.72,115.15$. HRMS (ESI-TOF): $m / z:$ : $\mathrm{M}+$ $\mathrm{H}]+$ Calcd for $\mathrm{C}_{22} \mathrm{H}_{12} \mathrm{~N}_{3} \mathrm{O}$ : 334.0975; Found 334.0980. UV-vis (DMSO, $\left.293 \mathrm{~K}\right) \lambda[\mathrm{nm}]\left(\varepsilon\right.$ in $\left.\mathrm{M}^{-1} \mathrm{~cm}^{-1}\right): 462$ (17 700). 


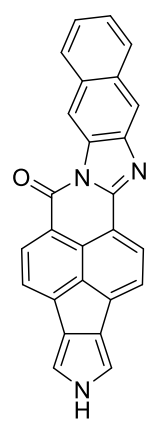

Naphtho[2',3':4,5]imidazo[2,1-a]pyrrolo[3',4':2,3]indeno[6,7,1-def]isoquinolin-6(2H)-one (7). A suspension of compound 5 ( $26 \mathrm{mg}, 0.100 \mathrm{mmol}$ ), 2,3-diaminonaphthalene (31.49 mg, $0.20 \mathrm{mmol}$ ) and anhydrous zinc(II) chloride $(13.57 \mathrm{mg}, 0.100 \mathrm{mmol})$ in quinoline $(0.5 \mathrm{~mL})$ was purged with nitrogen for $5 \mathrm{~min}$ and then heated at $180^{\circ} \mathrm{C}$ for $4 \mathrm{~h}$. The reaction mixture was cooled down and poured into aqueous $5 \%$ hydrochloric acid $(25 \mathrm{~mL})$; the precipitate was centrifuged, washed with water until neutral, washed with methanol/dichloromethane $(1: 1 \mathrm{v} / \mathrm{v})$ and dried, to give product as a dark orange powder $(20 \mathrm{mg}, 52 \%) .{ }^{1} \mathrm{H}$ NMR $\left(600 \mathrm{MHz}, \mathrm{DMSO}-d_{6}, 300 \mathrm{~K}\right): \delta 11.15(1 \mathrm{H}, \mathrm{b}), 8.89(1 \mathrm{H}, \mathrm{s})$, $8.49\left(1 \mathrm{H}, \mathrm{d},{ }^{3} \mathrm{~J}=7.3 \mathrm{~Hz}\right), 8.43\left(1 \mathrm{H}, \mathrm{d},{ }^{3} \mathrm{~J}=7.3 \mathrm{~Hz}\right), 8.29(1 \mathrm{H}, \mathrm{s}), 8.12(1 \mathrm{H}, \mathrm{m}), 8.07(1 \mathrm{H}, \mathrm{m}), 7.72\left(1 \mathrm{H}, \mathrm{d},{ }^{3} \mathrm{~J}\right.$ $=7.3 \mathrm{~Hz}), 7.70\left(1 \mathrm{H}, \mathrm{d},{ }^{3} J=7.3 \mathrm{~Hz}\right), 7.50(2 \mathrm{H}, \mathrm{m}), 7.23\left(1 \mathrm{H}, \mathrm{dd},{ }^{3} J=2.4 \mathrm{~Hz},{ }^{4} J=1.0 \mathrm{~Hz}\right), 7.19\left(1 \mathrm{H}, \mathrm{dd},{ }^{3} J=\right.$ $\left.2.4 \mathrm{~Hz},{ }^{4} \mathrm{~J}=1.0 \mathrm{~Hz}\right) .{ }^{13} \mathrm{C}$ NMR $\left(151 \mathrm{MHz}\right.$, DMSO- $\left.d_{6}, 300 \mathrm{~K}\right): \delta 160.61,152.79,143.72,141.48,138.85$, $136.88,133.06,132.33,131.86,131.74,129.08,128.87,128.71,128.44,127.74,126.21,125.75$, 125.54, 120.16, 119.92, 119.65, 117.43, 117.13, 117.04, 116.46, 112.73. HRMS (ESI-TOF): $m / z:$ [M + $\mathrm{H}]+$ Calcd for $\mathrm{C}_{26} \mathrm{H}_{14} \mathrm{~N}_{3} \mathrm{O}$ : 384.1131; Found 384.1136. UV-vis (DMSO, $\left.293 \mathrm{~K}\right) \lambda[\mathrm{nm}]\left(\varepsilon\right.$ in $\left.\mathrm{M}^{-1} \mathrm{~cm}^{-1}\right): 486$ (23 600).

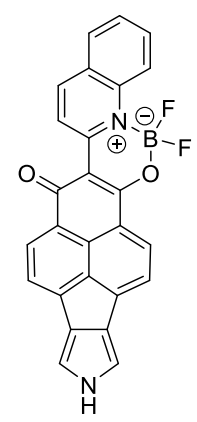

6,6-Difluoro-6,11-dihydro-15H-5 $\lambda^{4}, 6 \lambda^{4}$-pyrrolo[3"',4'":4",5"]cyclopenta[1",2",3":6',7']phenaleno$\left[2^{\prime}, 1^{\prime}: 5,6\right][1,3,2]$ oxazaborinino[3,4-a]quinolin-15-one (8). ${ }^{22}$ A suspension of compound 5 (52 mg, $0.191 \mathrm{mmol})$, and anhydrous zinc(II) chloride $(40.70 \mathrm{mg}, 0.30 \mathrm{mmol})$ in 2-methylquinoline $(0.363 \mathrm{~mL})$ was purged with nitrogen for $5 \mathrm{~min}$ and then heated at $200^{\circ} \mathrm{C}$ for $3 \mathrm{~h}$. The reaction mixture was cooled down and poured into aqueous $5 \%$ hydrochloric acid; the precipitate was centrifuged, washed with water until neutral and dried, to give a dark brown powder. This powder was suspended in toluene $(12 \mathrm{~mL})$ and $N$-ethyldiisopropylamine $(156 \mu \mathrm{L}, 0.89 \mathrm{mmol})$ and boron trifluoride diethyl etherate $(319 \mu \mathrm{L}, 2.59 \mathrm{mmol})$ were added and the mixture was heated at $60^{\circ} \mathrm{C}$ for $2.5 \mathrm{~h}$. The reaction mixture was cooled down, the precipitate was filtrated, dried and purified by column chromatography on silica with dichloromethane/methanol $(100: 0.5 \mathrm{v} / \mathrm{v})$ as the eluent to give the product as a dark brown powder (36 mg, 42\%). ${ }^{1} \mathrm{H}$ NMR (600 MHz, DMSO- $\left.d_{6}, 300 \mathrm{~K}\right): \delta 11.07(1 \mathrm{H}, \mathrm{b})$, $9.31\left(1 \mathrm{H}, \mathrm{d},{ }^{3} \mathrm{~J}=9.2 \mathrm{~Hz}\right), 8.86\left(1 \mathrm{H}, \mathrm{d},{ }^{3} J=9.2 \mathrm{~Hz}\right), 8.62(1 \mathrm{H}, \mathrm{m}), 8.30\left(1 \mathrm{H}, \mathrm{d},{ }^{3} J=7.4 \mathrm{~Hz}\right), 8.23\left(1 \mathrm{H}, \mathrm{d},{ }^{3} J=\right.$ $7.4 \mathrm{~Hz}), 8.18\left(1 \mathrm{H}, \mathrm{dd},{ }^{3} J=8.0 \mathrm{~Hz},{ }^{4} J=1.4 \mathrm{~Hz}\right), 8.01\left(1 \mathrm{H}, \mathrm{ddd},{ }^{3} J=8.7 \mathrm{~Hz},{ }^{3} J=7.0 \mathrm{~Hz},{ }^{4} J=1.6 \mathrm{~Hz}\right), 7.80$ $(1 \mathrm{H}, \mathrm{m}), 7.58\left(2 \mathrm{H}, \mathrm{d},{ }^{3} \mathrm{~J}=7.4 \mathrm{~Hz}\right), 7.17\left(1 \mathrm{H}, \mathrm{d},{ }^{3} \mathrm{~J}=2.4 \mathrm{~Hz}\right), 7.12\left(1 \mathrm{H}, \mathrm{d},{ }^{3} \mathrm{~J}=2.4 \mathrm{~Hz}\right) .{ }^{13} \mathrm{C}$ NMR $(151 \mathrm{MHz}$, 
DMSO- $\left.d_{6}, 300 \mathrm{~K}\right): \delta 181.40,167.55,152.94,143.24,141.73,141.18,139.19,137.09,132.99,132.38$, $131.98,129.48,128.39,128.32,128.10,127.51,126.11,125.46,122.98,121.94,120.25,119.93$, 119.66, 118.03, 117.34, 107.95. HRMS (ESI-TOF): $\mathrm{m} / \mathrm{z}:[\mathrm{M}+\mathrm{H}]+$ Calcd for $\mathrm{C}_{26} \mathrm{H}_{14} \mathrm{BF}_{2} \mathrm{~N}_{2} \mathrm{O}_{2}: 435.1115$;

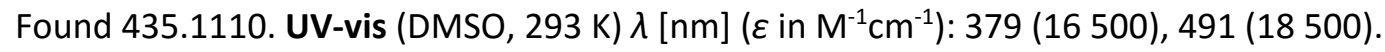

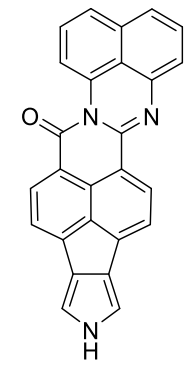

Pyrrolo[3", 4":2',3']indeno[6',7',1':4,5,6]isoquinolino[2,1-a]perimidin-6(2H)-one (9). A suspension of compound 5 (50 mg, $0.20 \mathrm{mmol}), 1,8$-diaminonaphthalene (157.33 $\mathrm{mg}, 0.10 \mathrm{mmol}$ ) and anhydrous zinc(II) chloride $(20.35 \mathrm{mg}, 0.15 \mathrm{mmol})$ in quinoline $(0.5 \mathrm{~mL})$ was purged with nitrogen for $5 \mathrm{~min}$ and then heated at $180^{\circ} \mathrm{C}$ for $5 \mathrm{~h}$. The reaction mixture was cooled down and poured into aqueous $5 \%$ hydrochloric acid, the precipitate was centrifuged, washed with water until neutral, washed with methanol/dichloromethane $(1: 1 \mathrm{v} / \mathrm{v})$ and dried, to give the product as a dark red powder $(60 \mathrm{mg}$, 79\%). ${ }^{1}$ H NMR (600 MHz, DMSO- $\left.d_{6}, 300 \mathrm{~K}\right): \delta 11.21(1 \mathrm{H}, \mathrm{b}), 8.53\left(1 \mathrm{H}, \mathrm{d},{ }^{3} J=7.4 \mathrm{~Hz}\right), 8.51\left(1 \mathrm{H}, \mathrm{d},{ }^{3} J=\right.$ $8.1 \mathrm{~Hz}), 8.33\left(1 \mathrm{H}, \mathrm{d},{ }^{3} \mathrm{~J}=7.4 \mathrm{~Hz}\right), 7.75(2 \mathrm{H}, \mathrm{m}), 7.62\left(1 \mathrm{H}, \mathrm{d}^{3}{ }^{3} \mathrm{~J}=8.1 \mathrm{~Hz}\right), 7.56\left(1 \mathrm{H}, \mathrm{d}^{3}{ }^{3} \mathrm{~J}=8.1 \mathrm{~Hz}\right), 7.52-$ $7.45(2 \mathrm{H}, \mathrm{m}), 7.29(1 \mathrm{H}, \mathrm{b}), 7.26(1 \mathrm{H}, \mathrm{b}), 7.24\left(1 \mathrm{H}, \mathrm{d},{ }^{3} \mathrm{~J}=7.4 \mathrm{~Hz}\right) .{ }^{13} \mathrm{C}$ NMR (151 MHz, DMSO-d, $\left.300 \mathrm{~K}\right)$ : $\delta 161.89,146.98,139.33,138.44,137.16,135.15,133.65,133.34,131.14,128.79,127.86,127.69$, $127.23,127.22,124.66,123.63,122.81,120.90,120.53,119.62,119.52,119.14,118.87,115.67$, 115.60, 115.17. HRMS (ESI-TOF): $\mathrm{m} / \mathrm{z}$ : [M + Na]+ Calcd for $\mathrm{C}_{26} \mathrm{H}_{13} \mathrm{~N}_{3} \mathrm{O}: 406.0951$; Found 406.0954 . UV-vis (DMSO, $293 \mathrm{~K}) \lambda[\mathrm{nm}]\left(\varepsilon\right.$ in $\left.\mathrm{M}^{-1} \mathrm{~cm}^{-1}\right): 512$ (17 100).

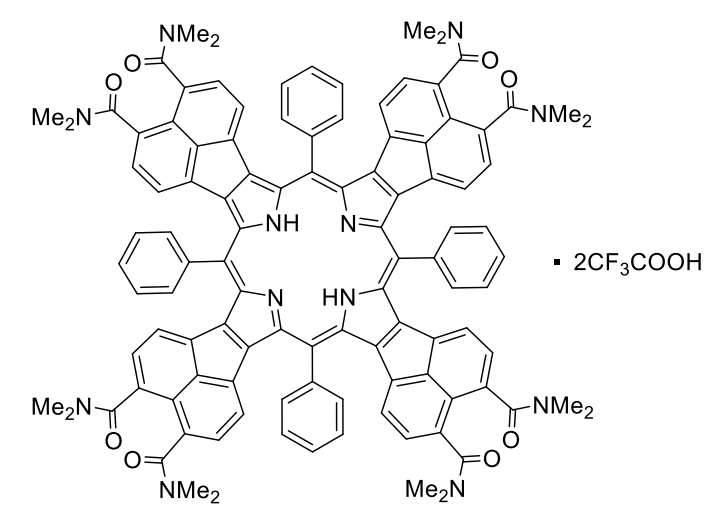

NDA-fused porphyrin diacid ([10- $\left.\left.\mathrm{H}_{4}\right][\mathrm{TFA}]_{2}\right)$. Solution of compound $3(600 \mathrm{mg}, 1.80 \mathrm{mmol})$ and benzaldehyde (201.23 $\mathrm{LL}, 1.98 \mathrm{mmol})$ in chloroform/methanol (181.8 mL, 100:1 v/v) was protected from light and purged with nitrogen for $10 \mathrm{~min}$. $p$-Toluenesulfonic acid monohydrate $(222.52 \mathrm{mg}$, $1.17 \mathrm{mmol}$ ) was added to the solution and the resulting mixture was stirred for $1 \mathrm{~h}$. Then 2,3dichloro-5,6-dicyano-1,4-benzoquinone ( $D D Q, 612.8 \mathrm{mg}, 2.70 \mathrm{mmol}$ ) was added and the mixture was stirred for additional $2 \mathrm{~h}$. The solvent was evaporated and the residue was purified by column chromatography on alumina (grade $\mathrm{V}$ ) with dichloromethane/methanol $(100: 0.8 \mathrm{v} / \mathrm{v}$ ) to give the product as violet solid. For additional purification, trifluoroacetic acid (TFAH, $50 \mu \mathrm{L}$ ) was added to the solution of the product in dichloromethane, and the compound was precipitated with $n$-hexane. The 
precipitate was filtered and dried in vacuum, to give the product as a dark-purple powder (350 mg, 42\%). When applied to pyrrole $2(900 \mathrm{mg}, 2.70 \mathrm{mmol})$ in dichloromethane $(270 \mathrm{~mL})$, the above procedure gave a significantly lower yield of $\left[10-\mathrm{H}_{4}\right][\mathrm{TFA}]_{2}$ (306 mg, 25\%). ${ }^{1} \mathbf{H} \mathbf{N M R}(600 \mathrm{MHz}$, chloroform- $d, 300 \mathrm{~K}): \delta$ (mixture of atropisomers) $8.93(8 \mathrm{H}, \mathrm{m}), 8.15-7.94(12 \mathrm{H}, \mathrm{m}), 7.08(8 \mathrm{H}, \mathrm{m}), 5.91$ $\left(8 \mathrm{H}, \mathrm{m}\right.$, overlapping with acid signal), $3.04(12 \mathrm{H}, \mathrm{s}), 2.99(12 \mathrm{H}, \mathrm{s}), 2.96(12 \mathrm{H}, \mathrm{s}), 2.60(12 \mathrm{H}, \mathrm{s}) .{ }^{13} \mathrm{C} \mathrm{NMR}$ (151 MHz, chloroform- $d, 300 \mathrm{~K}$ ): $\delta$ (mixture of atropisomers) 170.36, 169.85, 157.49 (q, ${ }^{2} J_{\mathrm{CF}}=38.4$ $\mathrm{Hz}), 140.83,140.27,139.52,138.17,136.11,135.97,135.64,132.25,131.85,130.94,130.73,127.65$, $127.43,125.94,123.52,121.20,114.28$ (q, ${ }^{1} J_{C F}=289.3 \mathrm{~Hz}$ ), 39.45, 34.90. UV-vis (dichloromethane, $293 \mathrm{~K}) \lambda[\mathrm{nm}]\left(\varepsilon\right.$ in $\left.\mathrm{M}^{-1} \mathrm{~cm}^{-1}\right): 577$ (285 100), 642 (9 700), 705 (21 400), 778 (17 200).

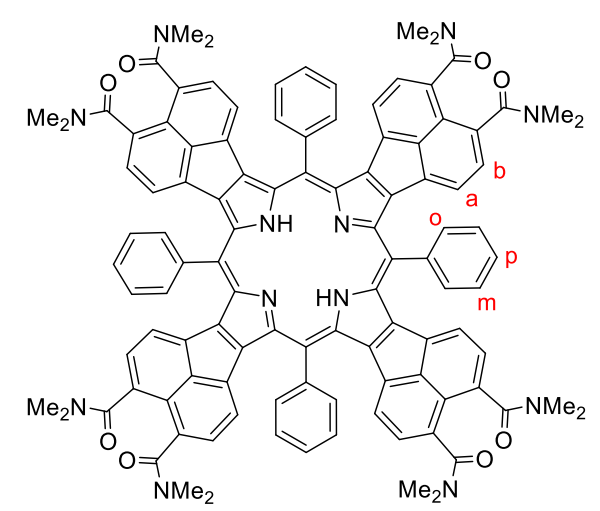

NDA-fused porphyrin free base $\left(\mathbf{1 0}-\mathbf{H}_{2}\right)$. A solution of compound [10- $\left.\mathrm{H}_{2}\right][T F A]_{2}(104 \mathrm{mg}, 0.055 \mathrm{mmol}$ ) in dichloromethane $(30 \mathrm{~mL}$ ) was shaken with a saturated aqueous solution of sodium bicarbonate (30 $\mathrm{mL}$ ), washed with water and brine and dried over anhydrous sodium sulfate to give the free base as a dark-violet solid (85 mg, 94\%). ${ }^{1} \mathrm{H}$ NMR (600 MHz, chloroform-d, $300 \mathrm{~K}$ ): $\delta 8.77(8 \mathrm{H}, \mathrm{b}), 8.08-7.84$ $(12 \mathrm{H}, \mathrm{m}), 7.01(8 \mathrm{H}, \mathrm{b}), 5.59(8 \mathrm{H}, \mathrm{b}), 3.05(12 \mathrm{H}, \mathrm{s}), 3.02(12 \mathrm{H}, \mathrm{s}), 3.01(12 \mathrm{H}, \mathrm{s}), 2.70(12 \mathrm{H}, \mathrm{s}) .{ }^{13} \mathrm{C}$ NMR (151 MHz, chloroform- $d, 300 \mathrm{~K}$ ): $\delta$ (mixture of atropisomers, partial assignment on the basis of 2D spectra) 170.68 (2, $\underline{\text { cONMe }} 2), 170.62$ (2, $\underline{\text { CONMe }} 2), 150.47,147.98,142.07$ (4, Ph-C), 140.94, 137.38

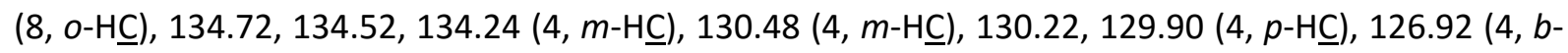
$\mathrm{H} \underline{\mathrm{C}}), 126.73(4, b-\mathrm{HC}), 124.75$ (8, $a-\mathrm{HC}), 123.58,120.98,39.53$ (4, CONMe 2 ), 39.34 (4, CONMe $\left.\underline{\mathrm{N}}_{2}\right), 34.82$ (4, CONMe 2 ), 34.70 (4, CONMe 2 ). HRMS (MALDI-TOF): $\mathrm{m} / \mathrm{z}$ : $[\mathrm{M}+\mathrm{H}]+$ Calcd for $\mathrm{C}_{108} \mathrm{H}_{87} \mathrm{~N}_{12} \mathrm{O}_{8}$ : 1679.6764; Found 1679.6666. UV-vis (dichloromethane, $293 \mathrm{~K}) \lambda[\mathrm{nm}]\left(\varepsilon\right.$ in $\left.\mathrm{M}^{-1} \mathrm{~cm}^{-1}\right): 409$ (53 100), 567 (195 600), 648 (23 100), 714 (14 400), 808 (2 900). 


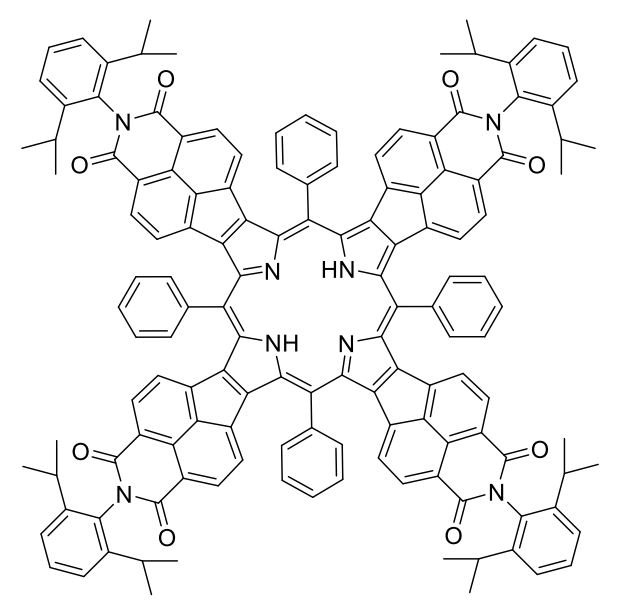

NMI-fused porphyrin free base $\left(\mathbf{1 1}-\mathrm{H}_{\mathbf{2}}\right)$. Obtained as described for [10- $\left.\mathrm{H}_{4}\right][T F A]$ (without conversion to dication), using pyrrole 4 ( $270 \mathrm{mg}, 0.642 \mathrm{mmol})$, and dichloromethane solvent (64 $\mathrm{mL}$ ). Dark green powder $(58 \mathrm{mg}, 18 \%)$. When a chloroform/methanol mixture $(20.2 \mathrm{~mL}, 100: 1 \mathrm{v} / \mathrm{v})$ was used as the solvent, the product (12 mg, 12\%) was obtained from pyrrole 4 (84 mg, $0.2 \mathrm{mmol}) .{ }^{1} \mathbf{H}$ NMR (500 $\mathrm{MHz}$, chloroform-d, $300 \mathrm{~K}): \delta 8.73\left(8 \mathrm{H}, \mathrm{d},{ }^{3} \mathrm{~J}=7.2 \mathrm{~Hz}\right), 8.16\left(4 \mathrm{H}, \mathrm{t},{ }^{3} \mathrm{~J}=7.5 \mathrm{~Hz}\right), 8.09(8 \mathrm{H}, \mathrm{m}), 8.01(8 \mathrm{H}$, $\left.\mathrm{t},{ }^{3} \mathrm{~J}=7.6 \mathrm{~Hz}\right), 7.44\left(4 \mathrm{H}, \mathrm{t},{ }^{3} \mathrm{~J}=7.9 \mathrm{~Hz}\right), 7.32\left(4 \mathrm{H}, \mathrm{d},{ }^{3} \mathrm{~J}=8.0 \mathrm{~Hz}\right), 7.25(4 \mathrm{H}$, overlapping with solvent signal), $5.66(8 \mathrm{H}, b), 2.80\left(4 \mathrm{H}, \operatorname{sept}^{3} \mathrm{~J}=6.7 \mathrm{~Hz}\right), 2.62\left(4 \mathrm{H}, \operatorname{sept}^{3} \mathrm{~J}=6.7 \mathrm{~Hz}\right), 1.21\left(24 \mathrm{H}, \mathrm{d},{ }^{3} \mathrm{~J}=6.7 \mathrm{~Hz}\right)$, $1.01\left(24 \mathrm{H}, \mathrm{d},{ }^{3} \mathrm{~J}=6.7 \mathrm{~Hz}\right) .{ }^{13} \mathrm{C}$ NMR $(125 \mathrm{MHz}$, chloroform- $d, 300 \mathrm{~K}): \delta 163.71,149.93,145.87,145.75$, $142.51,141.51,138.38,137.12,134.21,132.24,131.18,130.80,129.56,125.82,125.48,123.99$, 123.95, 122.70, 122.25, 29.24, 28.99, 24.09, 23.89. HRMS (MALDI-TOF): $\mathrm{m} / \mathrm{z}:[\mathrm{M}+\mathrm{H}$ ]+ Calcd for $\mathrm{C}_{140} \mathrm{H}_{107} \mathrm{~N}_{8} \mathrm{O}_{8}$ : 2027.8206; Found 2017.8199. UV-vis (dichloromethane, $\left.293 \mathrm{~K}\right) \lambda[\mathrm{nm}]\left(\varepsilon\right.$ in $\left.\mathrm{M}^{-1} \mathrm{~cm}^{-1}\right)$ : 458 (76 100), 615 (130 200), 717 (15 800), 776 (14 000), 875 (2 400).

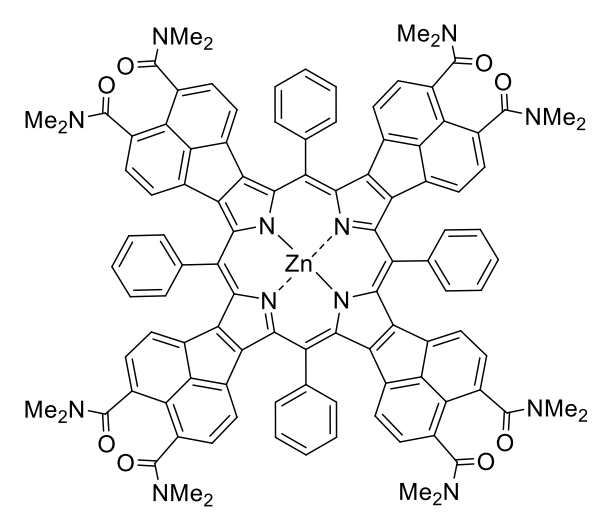

NDA-fused porphyrin zinc(II) complex (10-Zn). A saturated solution of zinc(II) acetate in methanol (5 $\mathrm{mL}$ ) was added to the solution of compound $\left[10-\mathrm{H}_{4}\right][\mathrm{TFA}]_{2}(50 \mathrm{mg}, 0.026 \mathrm{mmol})$ in chloroform and the resulting mixture was refluxed for $1 \mathrm{~h}$. The reaction mixture was cooled down, diluted with chloroform, washed with water and brine, and dried over anhydrous sodium sulfate. The solvent was evaporated, the residue was dissolved in dichloromethane and the compound was precipitated with $n$-hexane. The precipitate was filtered and dried in vacuum, to give the product as a blue-violet powder (41 mg, 90\%). HRMS (MALDI-TOF): $\mathrm{m} / \mathrm{z}$ : [M + Na]+ Calcd for $\mathrm{C}_{108} \mathrm{H}_{84} \mathrm{~N}_{12} \mathrm{O}_{8} \mathrm{ZnNa}$ : 1763.5718 ; Found 1763.5660. UV-vis (toluene $+1 \%$ pyridine, $293 \mathrm{~K}) \lambda[\mathrm{nm}]\left(\varepsilon\right.$ in $\left.\mathrm{M}^{-1} \mathrm{~cm}^{-1}\right): 353(16700), 417$ (31 900), 583 (139 000), 705 (14 400), 775 (4 500). 


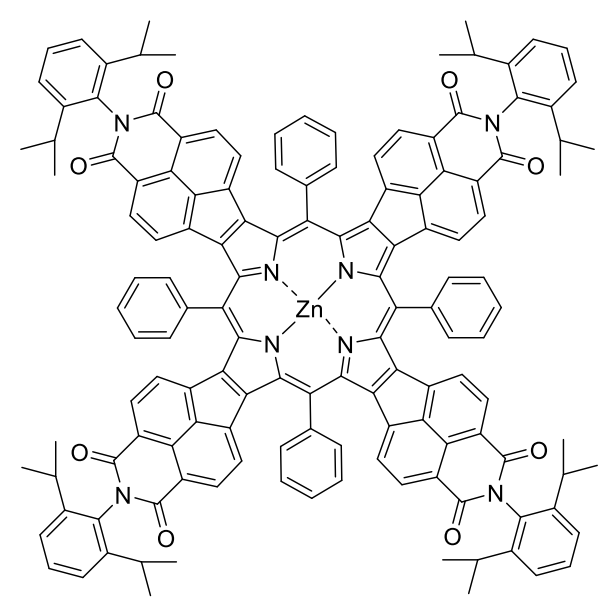

NMI-fused porphyrin zinc(II) complex (11-Zn). A solution of compound $10-\mathrm{H}_{\mathbf{2}}(130 \mathrm{mg}, 0.077 \mathrm{mmol})$ in concentrated hydrochloric acid $(30 \mathrm{~mL})$ was refluxed for $20 \mathrm{~h}$. The resulting dark-blue precipitate was filtered, washed with water and diethyl ether, and dried in vacuum to give product $\mathbf{S 6}$ as a dark blue powder (104 mg). The solid was suspended in glacial acetic acid $(0.8 \mathrm{~mL})$, and 2,6diisopropylaniline $(353 \mu \mathrm{L}, 1.87 \mathrm{mmol}$ ) was added. The mixture was purged with nitrogen for $5 \mathrm{~min}$ and refluxed in a pressure tube at $160{ }^{\circ} \mathrm{C}$ for $20 \mathrm{~h}$. The reaction mixture was cooled down, diluted with water, and extracted with dichloromethane. The organic phase was washed with water and brine, dried over anhydrous sodium sulfate, and concentrated in vacuum. A saturated solution of zinc(II) acetate in methanol $(10 \mathrm{~mL})$ was added to the solution of the resulting dark green solid in chloroform $(10 \mathrm{~mL})$ and the solution was refluxed for $1 \mathrm{~h}$. The reaction mixture was cooled down, diluted with chloroform, washed with water and brine, and dried over anhydrous sodium sulfate. The solvent was evaporated in vacuum and the residue was washed several times with methanol. The remaining dark green solid was dissolved in dichloromethane and precipitated with $n$-hexane; the precipitate was dried in vacuum to give the product as dark-green powder ( $143 \mathrm{mg}, 87 \%$ for 3 steps). ${ }^{1} \mathbf{H}$ NMR (600 MHz, chloroform- $\left.d, 300 \mathrm{~K}\right): \delta 8.70\left(8 \mathrm{H}, \mathrm{dd},{ }^{3} \mathrm{~J}=7.9 \mathrm{~Hz},{ }^{4} \mathrm{~J}=1.1 \mathrm{~Hz}\right), 8.18(4 \mathrm{H}, \mathrm{m}), 8.09$ $\left(8 \mathrm{H}, \mathrm{d},{ }^{3} \mathrm{~J}=7.9 \mathrm{~Hz}\right), 8.03\left(8 \mathrm{H}, \mathrm{t},{ }^{3} \mathrm{~J}=7.7 \mathrm{~Hz}\right), 7.43\left(4 \mathrm{H}, \mathrm{t},{ }^{3} \mathrm{~J}=7.9 \mathrm{~Hz}\right), 7.31\left(4 \mathrm{H}, \mathrm{dd},{ }^{3} \mathrm{~J}=8.3 \mathrm{~Hz},{ }^{4} \mathrm{~J}=1.2\right.$ $\mathrm{Hz}), 7.24\left(4 \mathrm{H}\right.$, overlapping with solvent signal), $5.57\left(8 \mathrm{H}, \mathrm{d},{ }^{3} \mathrm{~J}=7.6 \mathrm{~Hz}\right), 2.82\left(4 \mathrm{H}\right.$, sept, $\left.{ }^{3} \mathrm{~J}=6.7 \mathrm{~Hz}\right)$, $2.61\left(4 \mathrm{H}\right.$, sept, $\left.^{3} \mathrm{~J}=6.7 \mathrm{~Hz}\right), 1.21\left(24 \mathrm{H}, \mathrm{d},{ }^{3} \mathrm{~J}=6.7 \mathrm{~Hz}\right), 1.00\left(24 \mathrm{H}, \mathrm{d},{ }^{3} \mathrm{~J}=6.7 \mathrm{~Hz}\right) .{ }^{13} \mathrm{C}$ NMR $(151 \mathrm{MHz}$, chloroform-d, $300 \mathrm{~K}$ ): $\delta 163.78,148.37,146.13,145.80,145.78,142.54,138.90,136.98,134.20$, $132.18,130.87,130.83,129.52,125.67,125.49,123.94,123.31,122.42,29.22,28.99,24.07,23.85$. HRMS (MALDI-TOF): $m / z$ : [M + H]+ Calcd for $\mathrm{C}_{140} \mathrm{H}_{105} \mathrm{~N}_{8} \mathrm{O}_{8} \mathrm{Zn}$ : 2089.7341; Found 2089.7991. UV-vis (toluene $+1 \%$ pyridine, $293 \mathrm{~K}$ ) $\lambda[\mathrm{nm}]\left(\varepsilon\right.$ in $\left.\mathrm{M}^{-1} \mathrm{~cm}^{-1}\right): 387$ (40 900), 464 (91 000), 632 (196 700), 758 (23 900), 838 (10 500).

Compound 11- $\mathrm{Zn}\left(29 \mathrm{mg}, 93 \%\right.$ ) was also prepared from $11-\mathrm{H}_{2}$ (30 mg, $0.015 \mathrm{mmol}$ ) in the same manner as described for $\mathbf{1 0 - Z n}$. 
Additional Schemes 


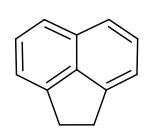

$\underset{43 \%}{\stackrel{1)}{\longrightarrow}}$

s1

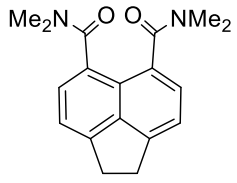

S2
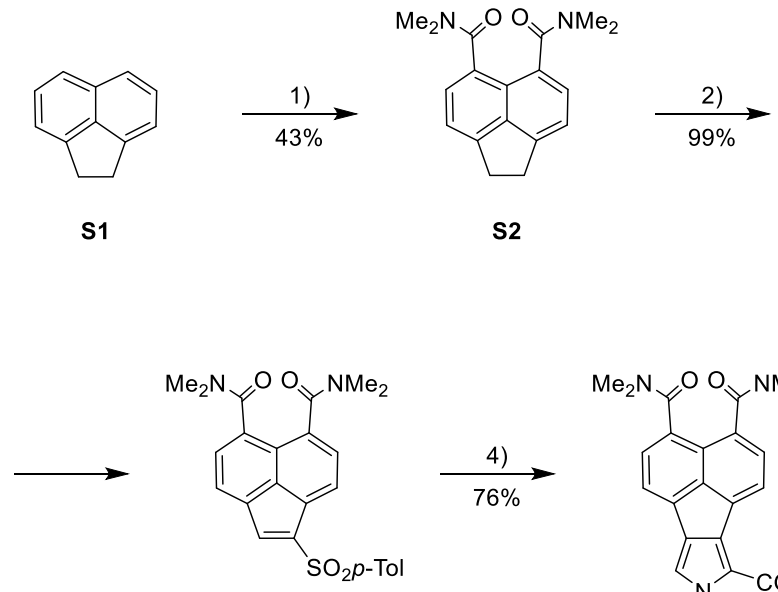

S4

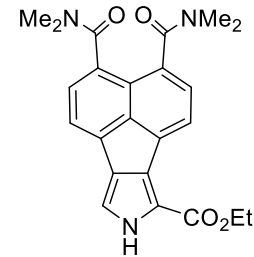

S5

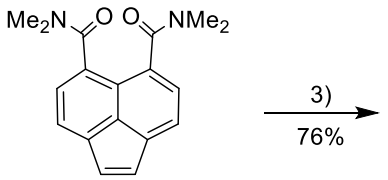

S3

Scheme S1. Synthesis of pyrrole 2. Reagents and conditions: 1) $\mathrm{Me}_{2} \mathrm{NCOCl}, \mathrm{AlCl}_{3}, \mathrm{PhCl}, 80^{\circ} \mathrm{C}$ to reflux; 2) (i) NBS, (PhCOO) ${ }_{2}, \mathrm{CHCl}_{3}$, reflux; (ii) $\mathrm{Zn}$, EtOH, reflux; 4) (i) $p$ - $\mathrm{TolSO}_{2} \mathrm{Na}, \mathrm{I}_{2}, \mathrm{DCM}-\mathrm{H}_{2} \mathrm{O}$ (1:1), RT; (ii) DBU, toluene, $\mathrm{RT}$; 5) $\mathrm{KOH},\left(\mathrm{CH}_{2} \mathrm{OH}\right)_{2}, 196{ }^{\circ} \mathrm{C}$. 


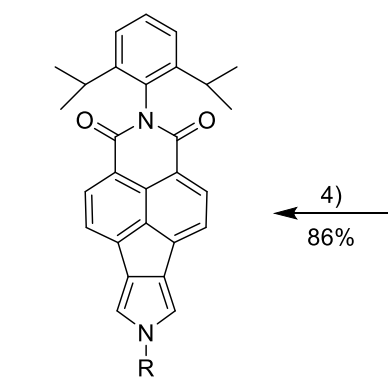

4' $\mathrm{R}=\mathrm{CH}_{2} \mathrm{CH}\left(\mathrm{CH}_{2} \mathrm{CH}_{3}\right)_{2}$<smiles></smiles>

4

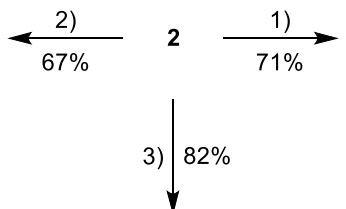

$\checkmark$

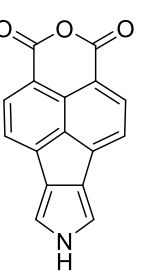

5

Scheme S2. Synthesis of pyrroles 1, 4 and 5. Reagents and conditions: 1) $\mathrm{LiAlH}_{4}, \mathrm{THF}, 0{ }^{\circ} \mathrm{C}$ to reflux; 2) 2,6-diisopropylaniline, $\left.\mathrm{AcOH}, 160^{\circ} \mathrm{C} ; 3\right) \mathrm{AcOH}, 170^{\circ} \mathrm{C}$; 4) 3-(bromomethyl)pentane, $\mathrm{NaH}, \mathrm{DMF}, 0^{\circ} \mathrm{C}$ to RT. 


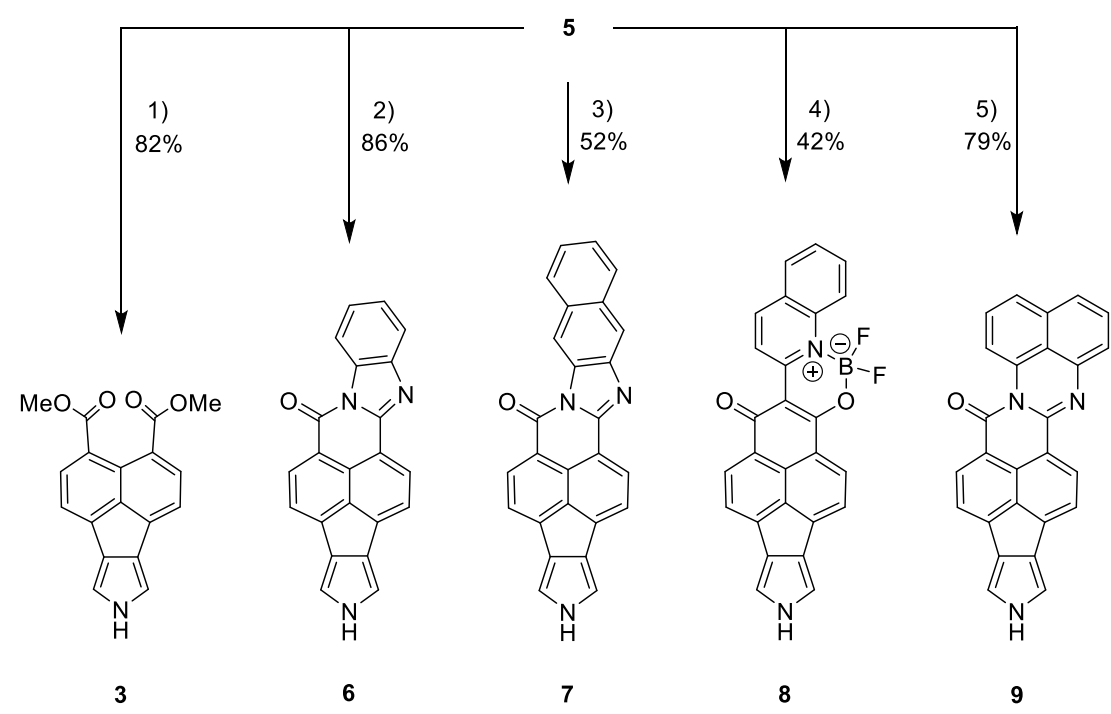

Scheme S3. Synthesis of pyrroles 3 and 6-9. Reagents and conditions: 1) Mel, DBU, MeOH, $70{ }^{\circ} \mathrm{C} ; 2$ ) o-phenylenediamine, $\mathrm{ZnCl}_{2}$, quinoline, $230{ }^{\circ} \mathrm{C}$; 3) 2,3-diaminonaphthalene, $\mathrm{ZnCl}_{2}$, quinoline, $180{ }^{\circ} \mathrm{C}$; 4 ) (i) $\mathrm{ZnCl}_{2}$, quinaldine, $200{ }^{\circ} \mathrm{C}$; (ii) $\mathrm{BF}_{3} \cdot \mathrm{Et}_{2} \mathrm{O}$, DIPEA, toluene, $60^{\circ} \mathrm{C}$; 5) 1,8-diaminonaphthalene, $\mathrm{ZnCl}_{2}$, quinoline, $180^{\circ} \mathrm{C}$. 

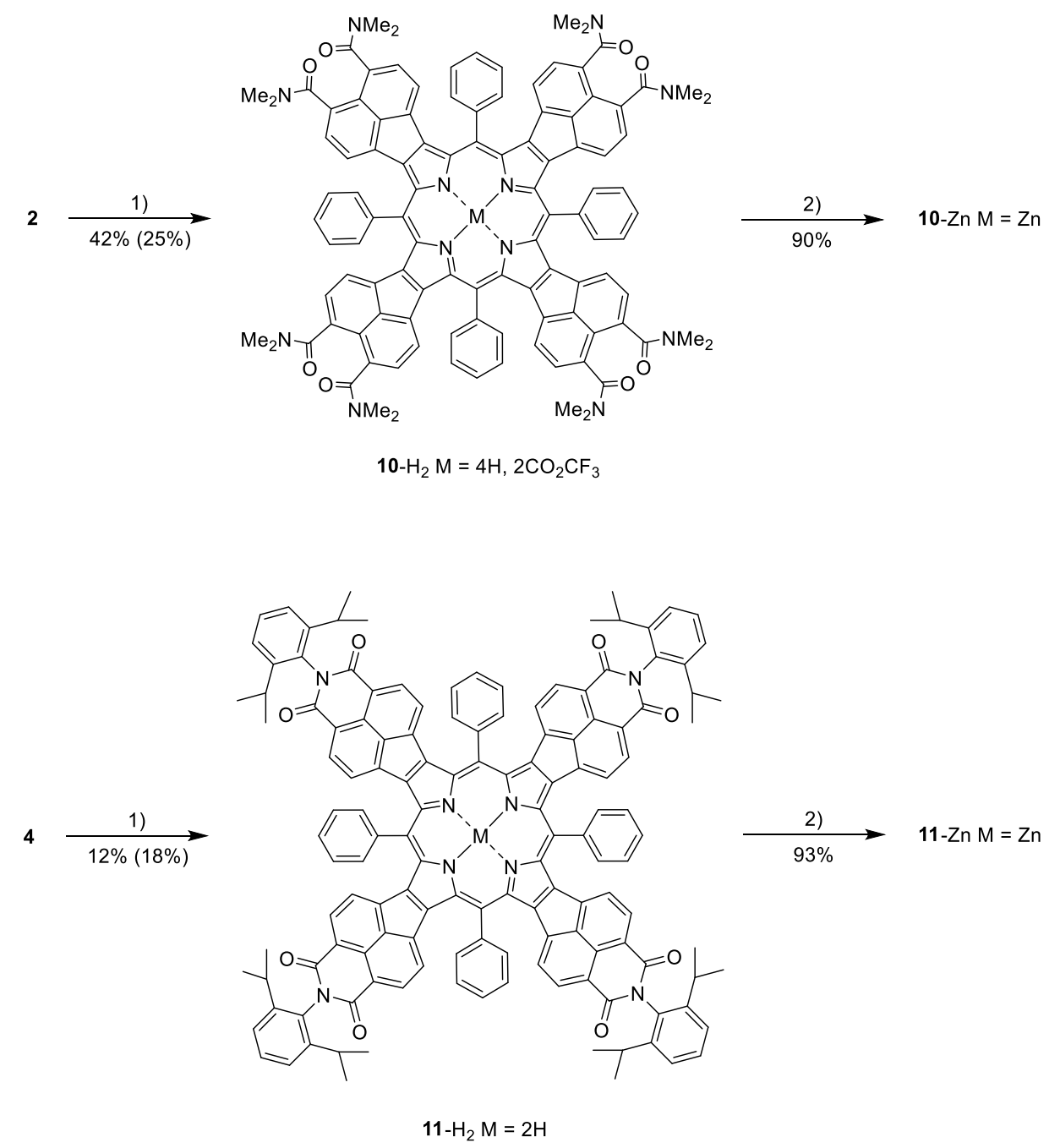

Scheme S4. Synthesis of porphyrins $10-\mathrm{H}_{2}(\mathbf{1 0}-\mathrm{Zn})$ and $11-\mathrm{H}_{2}$ (11-Zn). Reagents and conditions: 1) (i) benzaldehyde, $p$-TsOH· $\mathrm{H}_{2} \mathrm{O}, \mathrm{CHCl}_{3} / \mathrm{MeOH}$ (100:1 v/v) (or DCM), RT; (ii) DDQ, RT; (iii) TFA (only for 10; 2) (i) $\mathrm{HCl}_{\text {conc, }}$ reflux; (ii) 2,6-diisopropylaniline, $\mathrm{AcOH}, 160^{\circ} \mathrm{C}$; (iii) $\mathrm{Zn}(\mathrm{OAc})_{2}, \mathrm{CHCl}_{3} / \mathrm{MeOH}(1: 1 \mathrm{v} / \mathrm{v}$ ); 3) $\mathrm{Zn}(\mathrm{OAC})_{2}, \mathrm{CHCl}_{3} / \mathrm{MeOH}(1: 1 \mathrm{v} / \mathrm{v})$. 


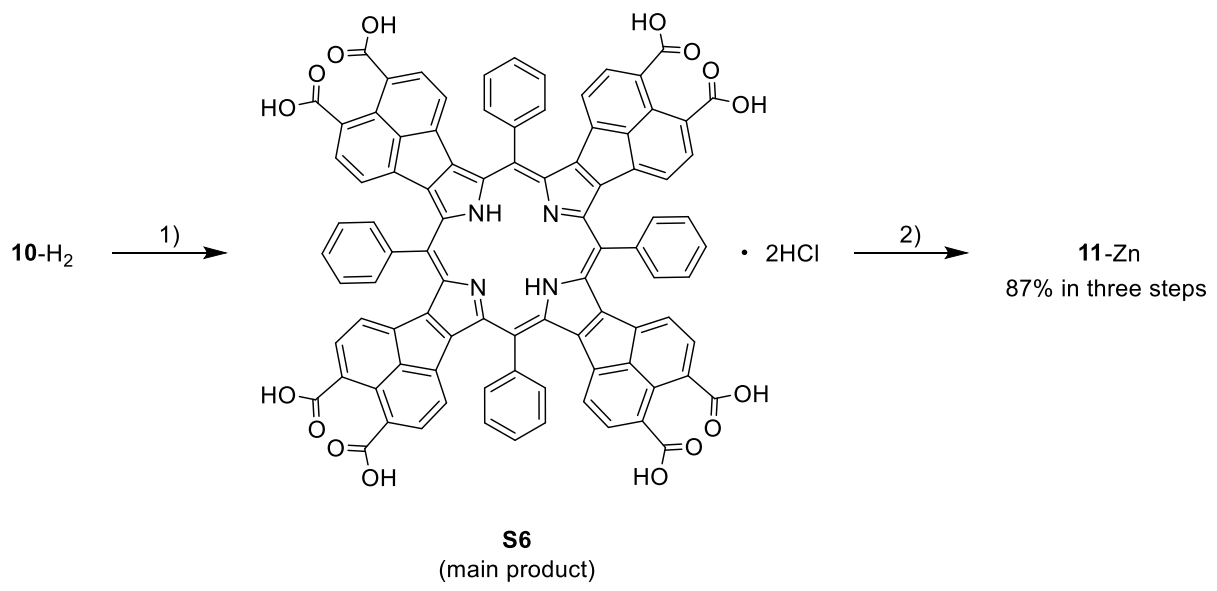

Scheme S5. Synthesis of porphyrin 11-Zn from 10- $\mathrm{H}_{2}$. Reagents and conditions: 1) $\mathrm{HCl}_{\text {conc, }}$ reflux; 2) (i) 2,6-diisopropylaniline, $\mathrm{AcOH}, 160{ }^{\circ} \mathrm{C}$; (ii) $\mathrm{Zn}(\mathrm{OAc})_{2}, \mathrm{CHCl}_{3} / \mathrm{MeOH}(1: 1 \mathrm{v} / \mathrm{v}$ ). Note: the $\mathbf{S 6}$ intermediate contains admixtures of acid-anhydrides. 
Additional Figures 


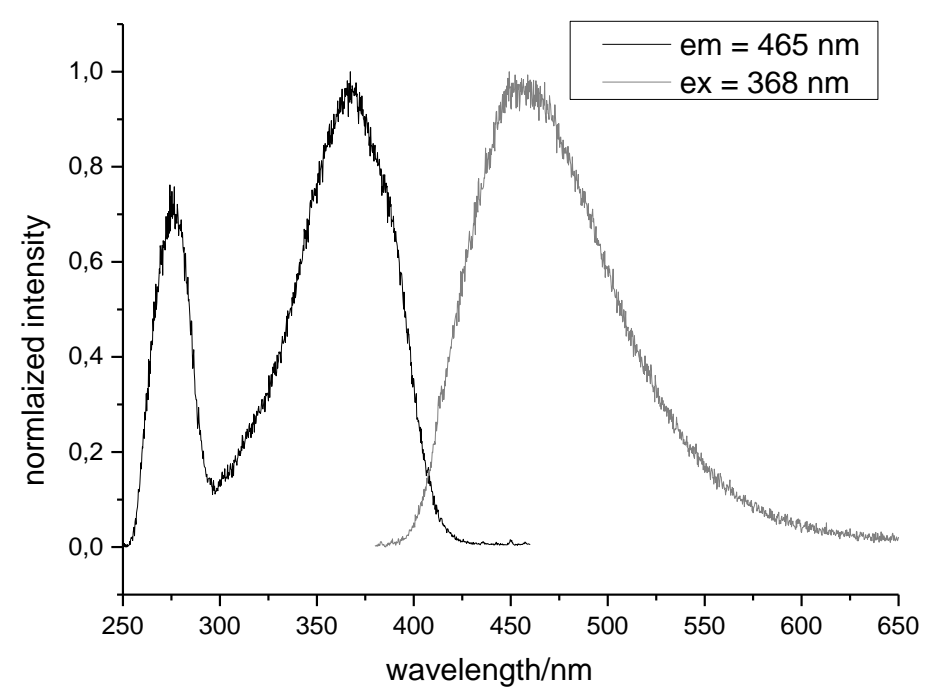

Figure S1. Emission spectra (excited at $368 \mathrm{~nm}$ ) and excitation spectra (monitored at $465 \mathrm{~nm}$ ) of compound 1 in DMSO.

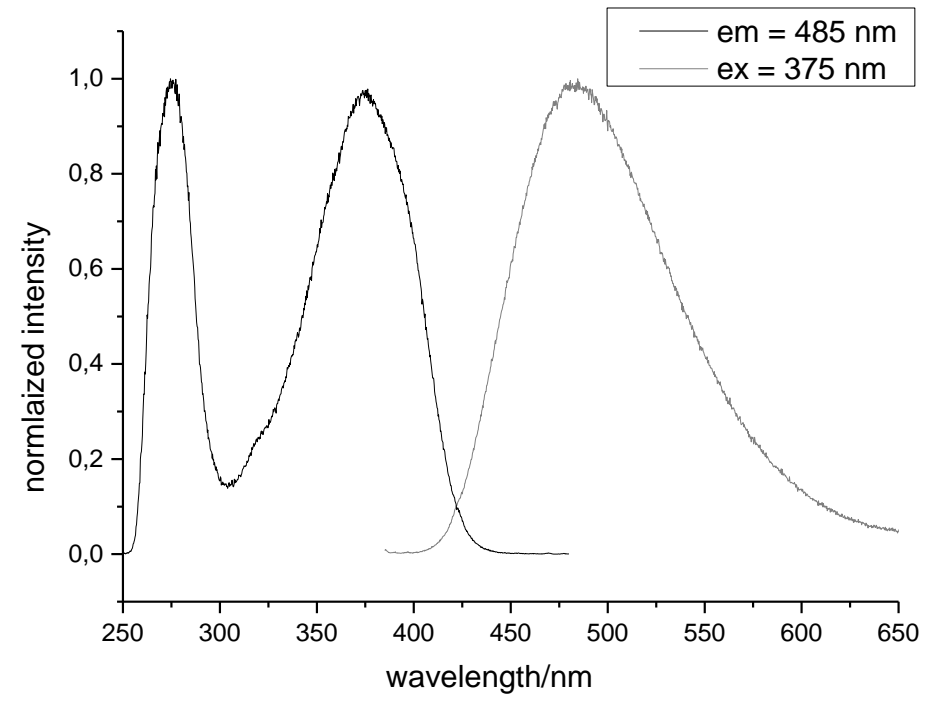

Figure S2. Emission spectra (excited at $375 \mathrm{~nm}$ ) and excitation spectra (monitored at $485 \mathrm{~nm}$ ) of compound 2 DMSO. 


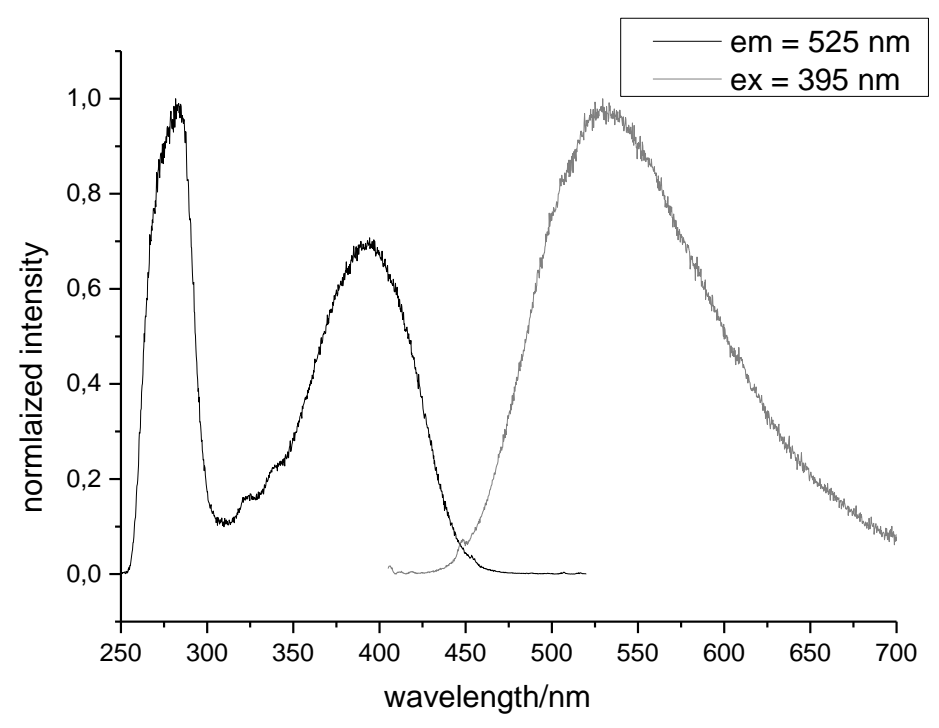

Figure S3. Emission spectra (excited at $395 \mathrm{~nm}$ ) and excitation spectra (monitored at $525 \mathrm{~nm}$ ) of compound $\mathbf{3}$ in DMSO.

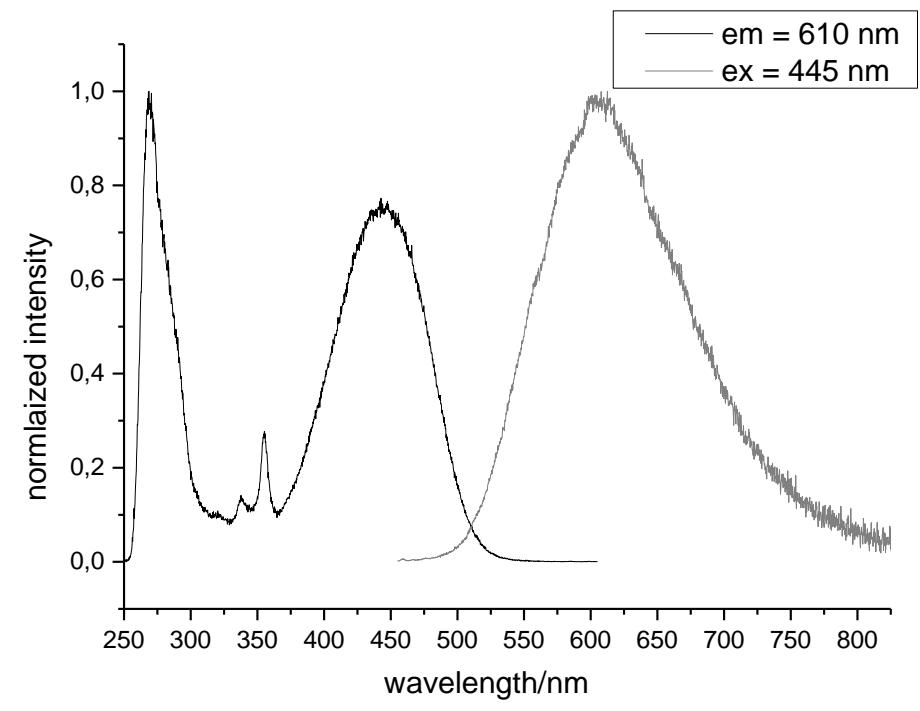

Figure S4. Emission spectra (excited at $445 \mathrm{~nm}$ ) and excitation spectra (monitored at $610 \mathrm{~nm}$ ) of compound $\mathbf{4}$ in DMSO. 


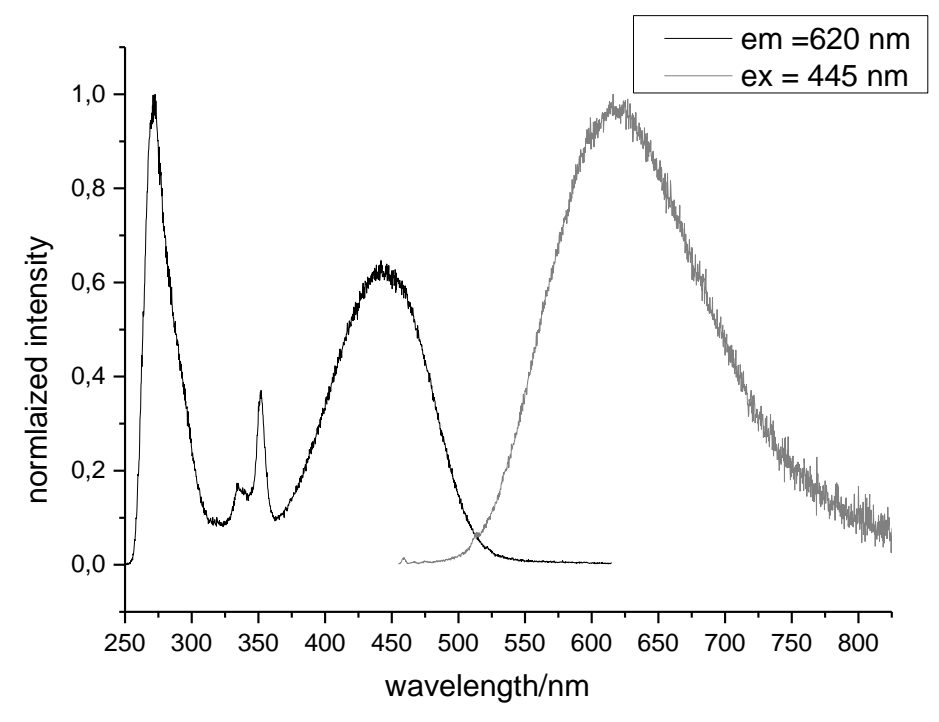

Figure S5. Emission spectra (excited at $445 \mathrm{~nm}$ ) and excitation spectra (monitored at $620 \mathrm{~nm}$ ) of compound 5 in DMSO.

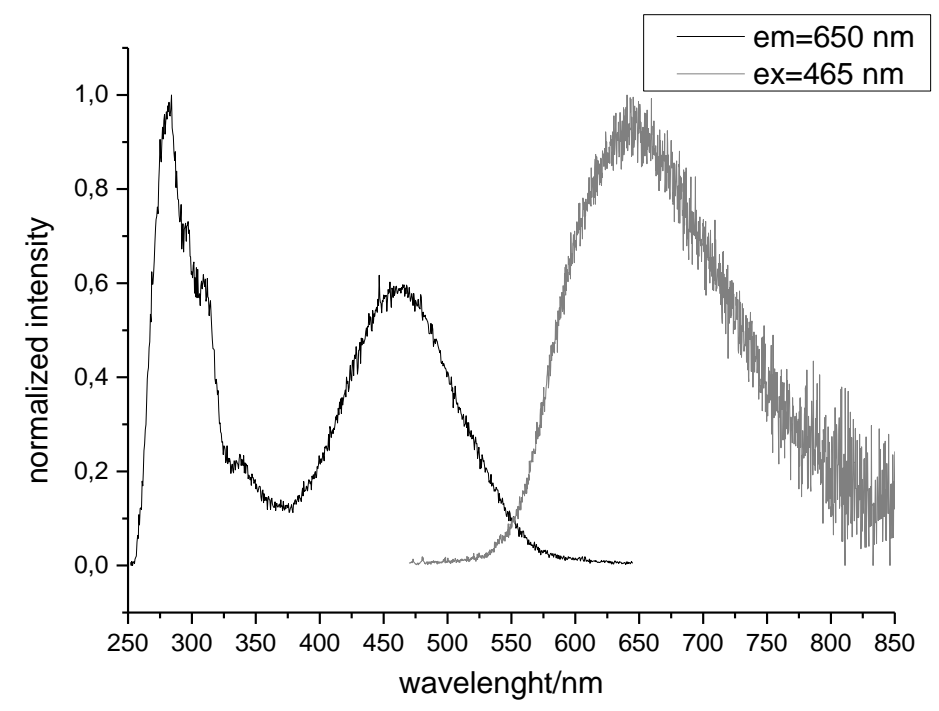

Figure S6. Emission spectra (excited at $465 \mathrm{~nm}$ ) and excitation spectra (monitored at $650 \mathrm{~nm}$ ) of compound 6 in DMSO. 


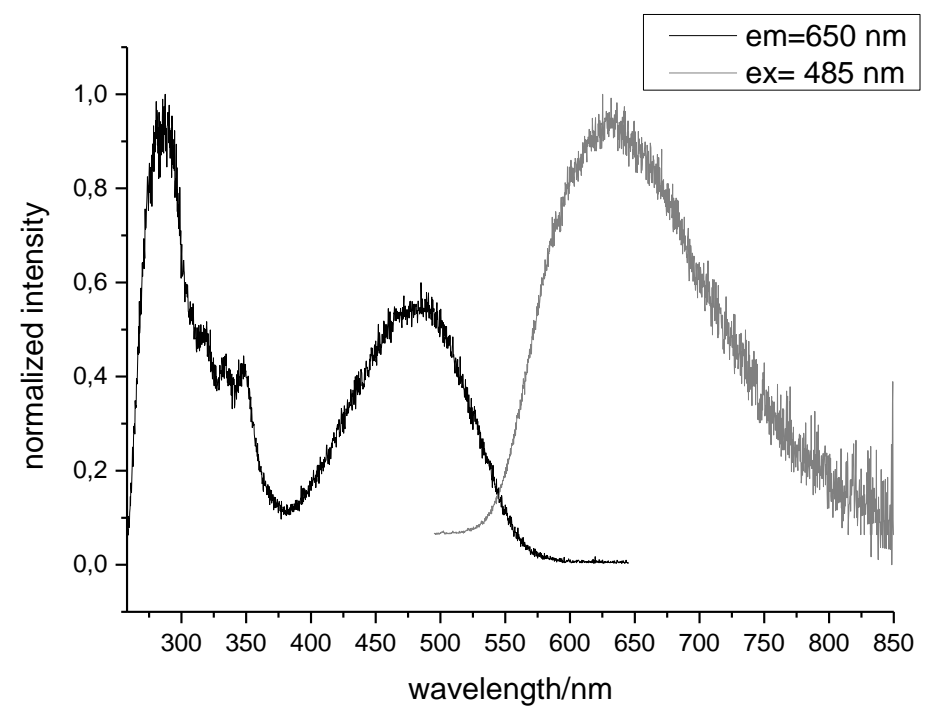

Figure S7. Emission spectra (excited at $485 \mathrm{~nm}$ ) and excitation spectra (monitored at $650 \mathrm{~nm}$ ) of compound 7 in DMSO.

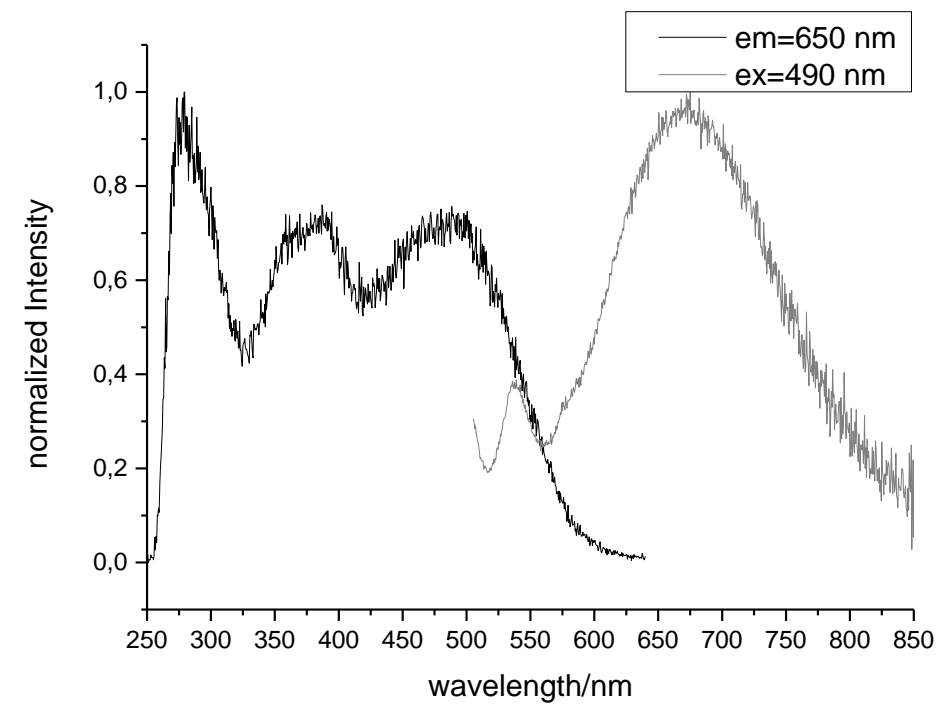

Figure S8. Emission spectra (excited at $490 \mathrm{~nm}$ ) and excitation spectra (monitored at $650 \mathrm{~nm}$ ) of compound 8 in DMSO. 


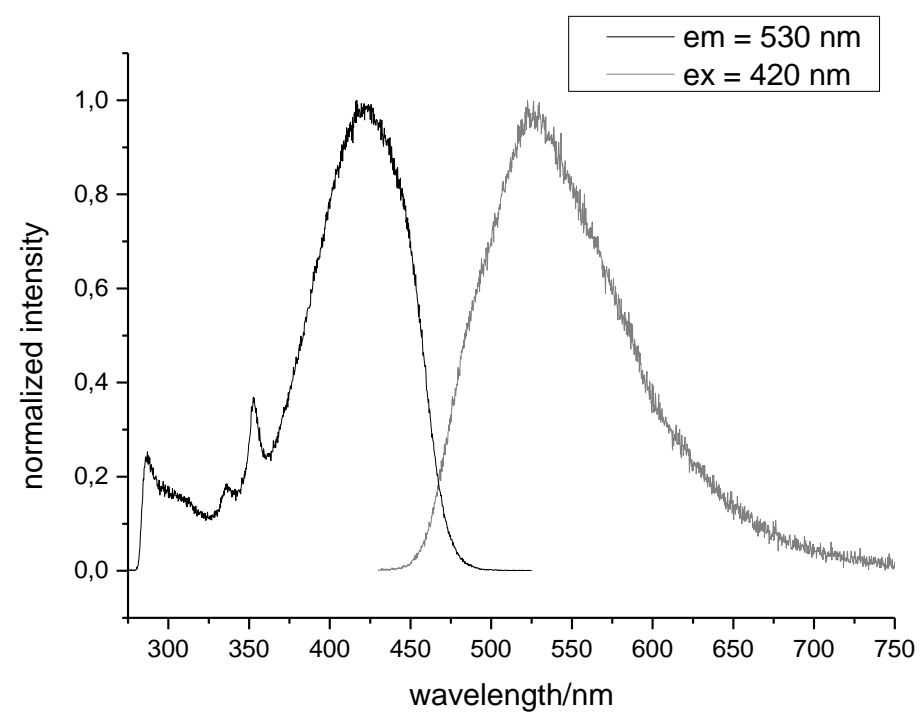

Figure S9. Emission spectra (excited at $420 \mathrm{~nm}$ ) and excitation spectra (monitored at $530 \mathrm{~nm}$ ) of compound 4 in toluene.

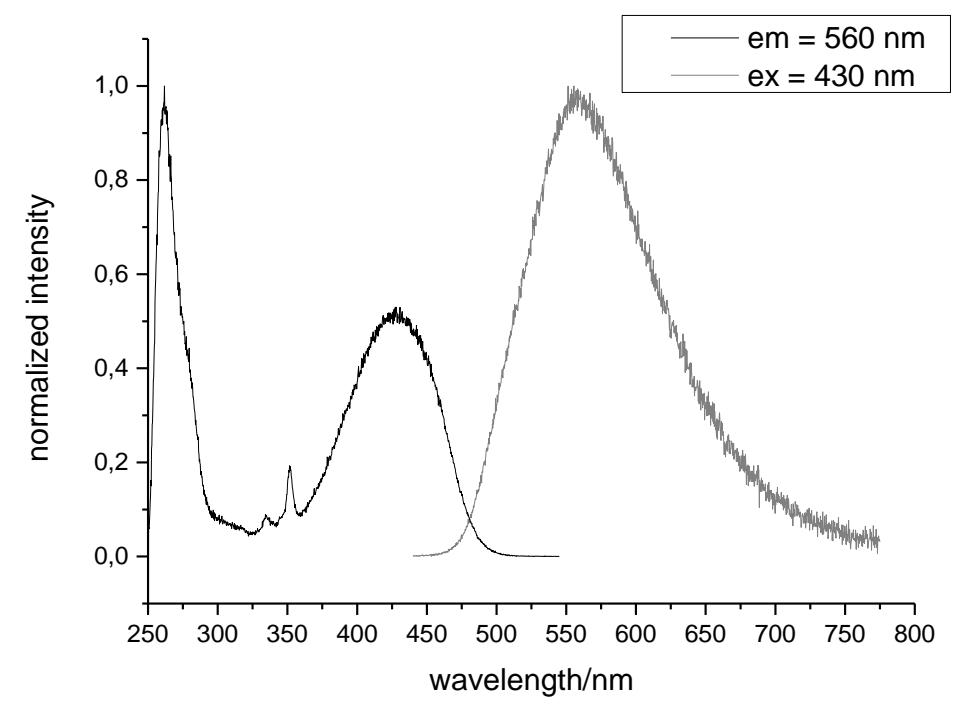

Figure S10. Emission spectra (excited at $430 \mathrm{~nm}$ ) and excitation spectra (monitored at $560 \mathrm{~nm}$ ) of compound $\mathbf{4}$ in EtOAc. 


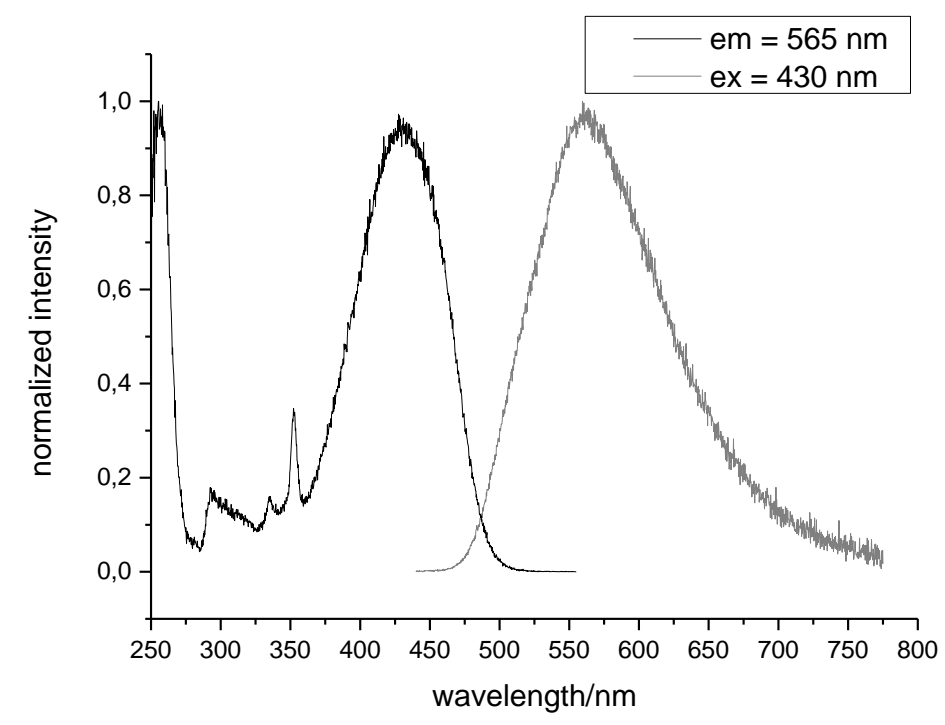

Figure S11. Emission spectra (excited at $430 \mathrm{~nm}$ ) and excitation spectra (monitored at $565 \mathrm{~nm}$ ) of compound 4 in THF.

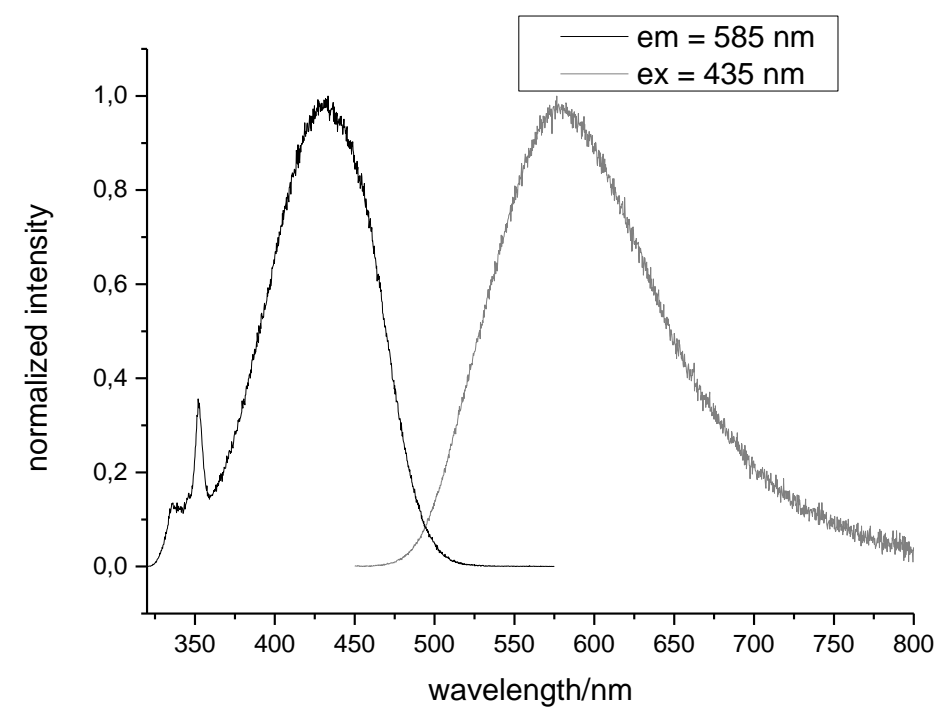

Figure S12. Emission spectra (excited at $435 \mathrm{~nm}$ ) and excitation spectra (monitored at $585 \mathrm{~nm}$ ) of compound $\mathbf{4}$ in acetone. 


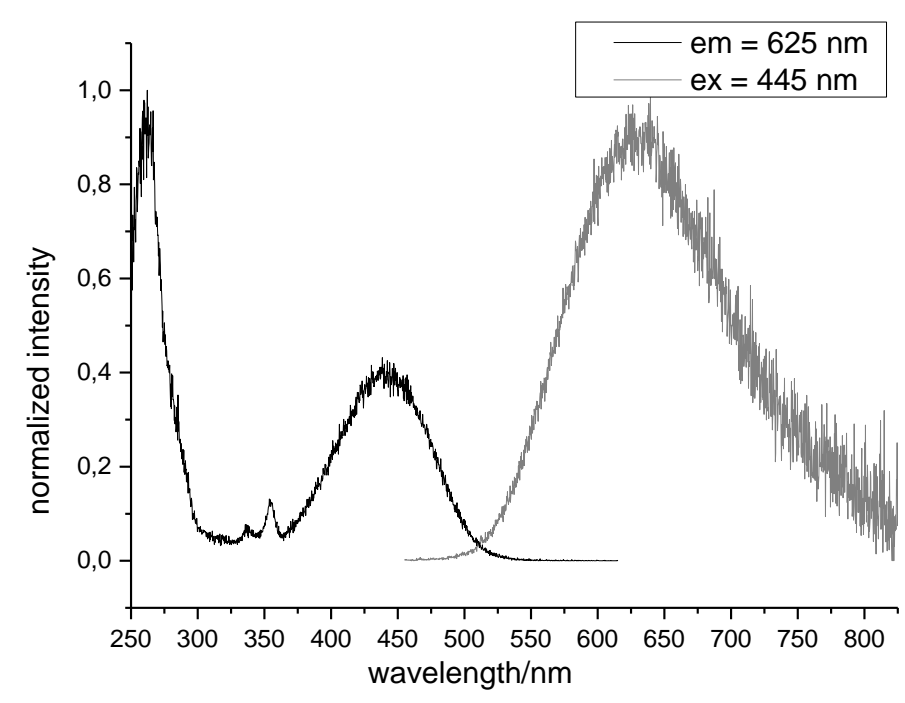

Figure S13. Emission spectra (excited at $445 \mathrm{~nm}$ ) and excitation spectra (monitored at $525 \mathrm{~nm}$ ) of compound 4 in $\mathrm{MeOH}$.

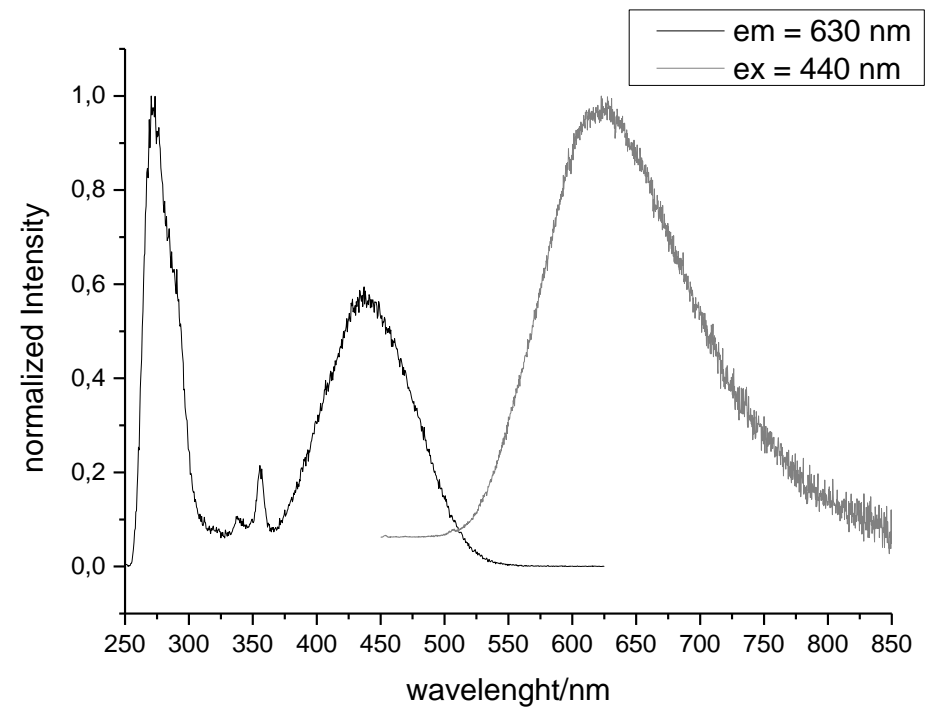

Figure S14. Emission spectra (excited at $440 \mathrm{~nm}$ ) and excitation spectra (monitored at $630 \mathrm{~nm}$ ) of compound 4 ' in DMSO. 


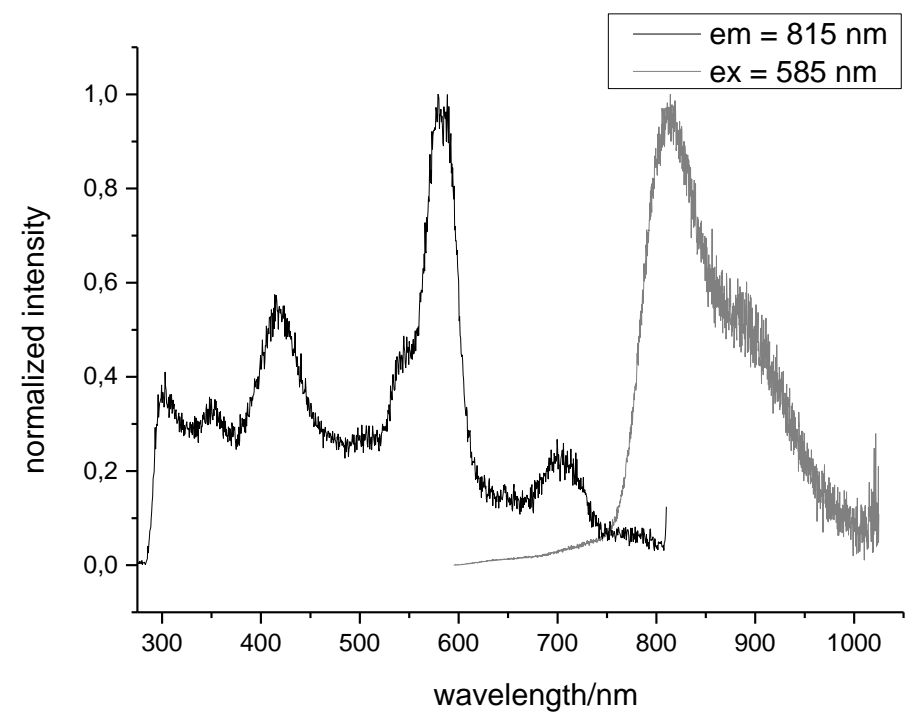

Figure S15. Emission spectra (excited at $585 \mathrm{~nm}$ ) and excitation spectra (monitored at $815 \mathrm{~nm}$ ) of compound $10-\mathrm{Zn}$ in toluene $+1 \%$ pyridine.

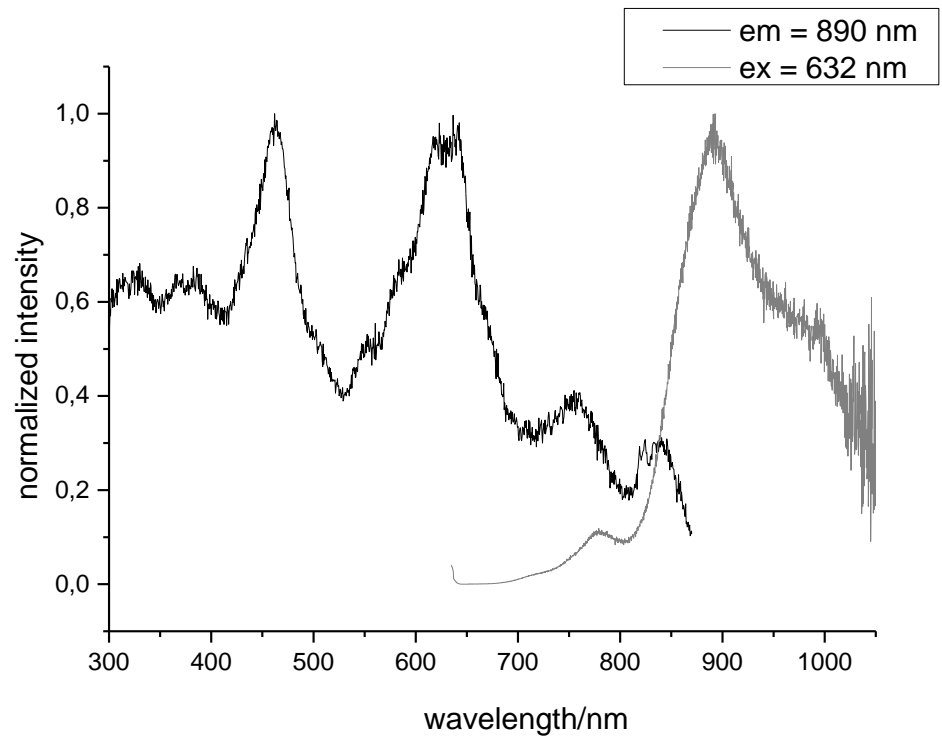

Figure S16. Emission spectra (excited at $632 \mathrm{~nm}$ ) and excitation spectra (monitored at $890 \mathrm{~nm}$ ) of compound $11-\mathrm{Zn}$ in toluene $+1 \%$ pyridine. 


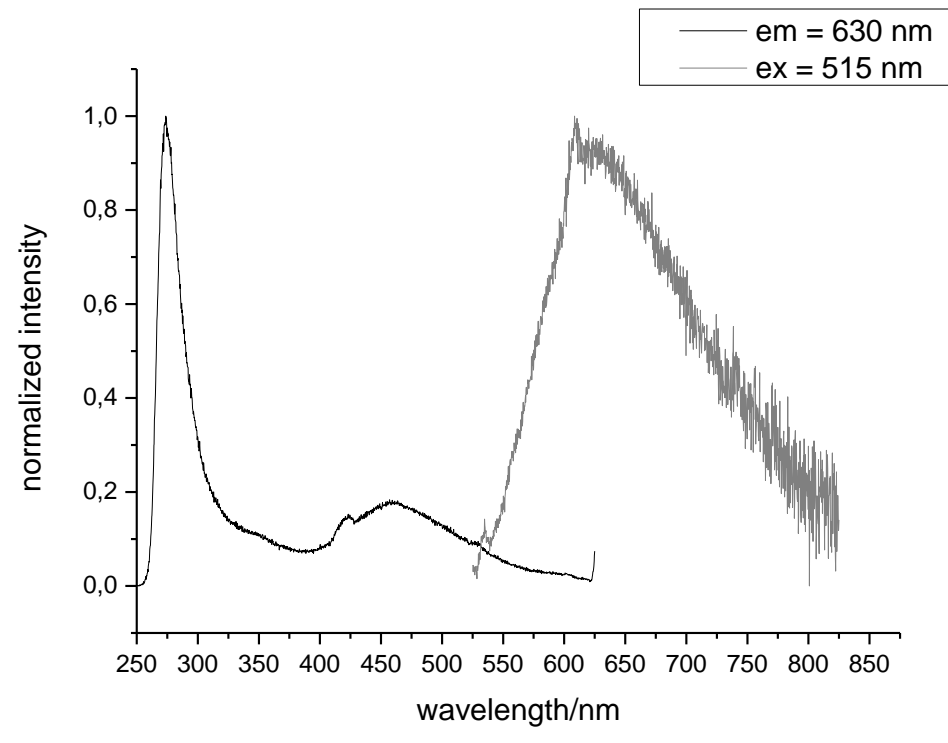

Figure S17. Emission spectra (excited at $515 \mathrm{~nm}$ ) and excitation spectra (monitored at $630 \mathrm{~nm}$ ) of compound 9 in DMSO. 


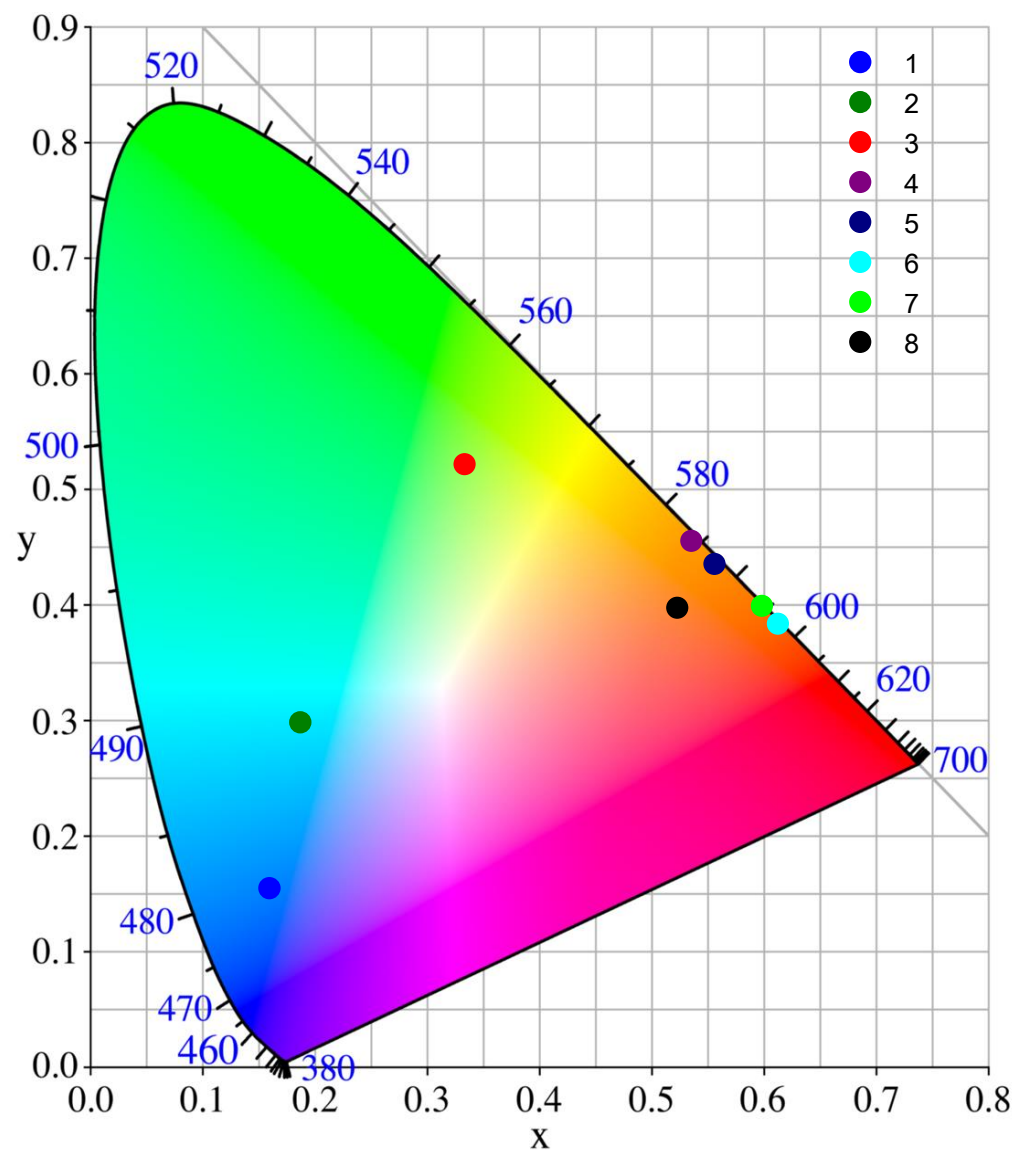

Figure S18. Chromaticity diagrams for 1-8 in dimethylsulfoxide. 


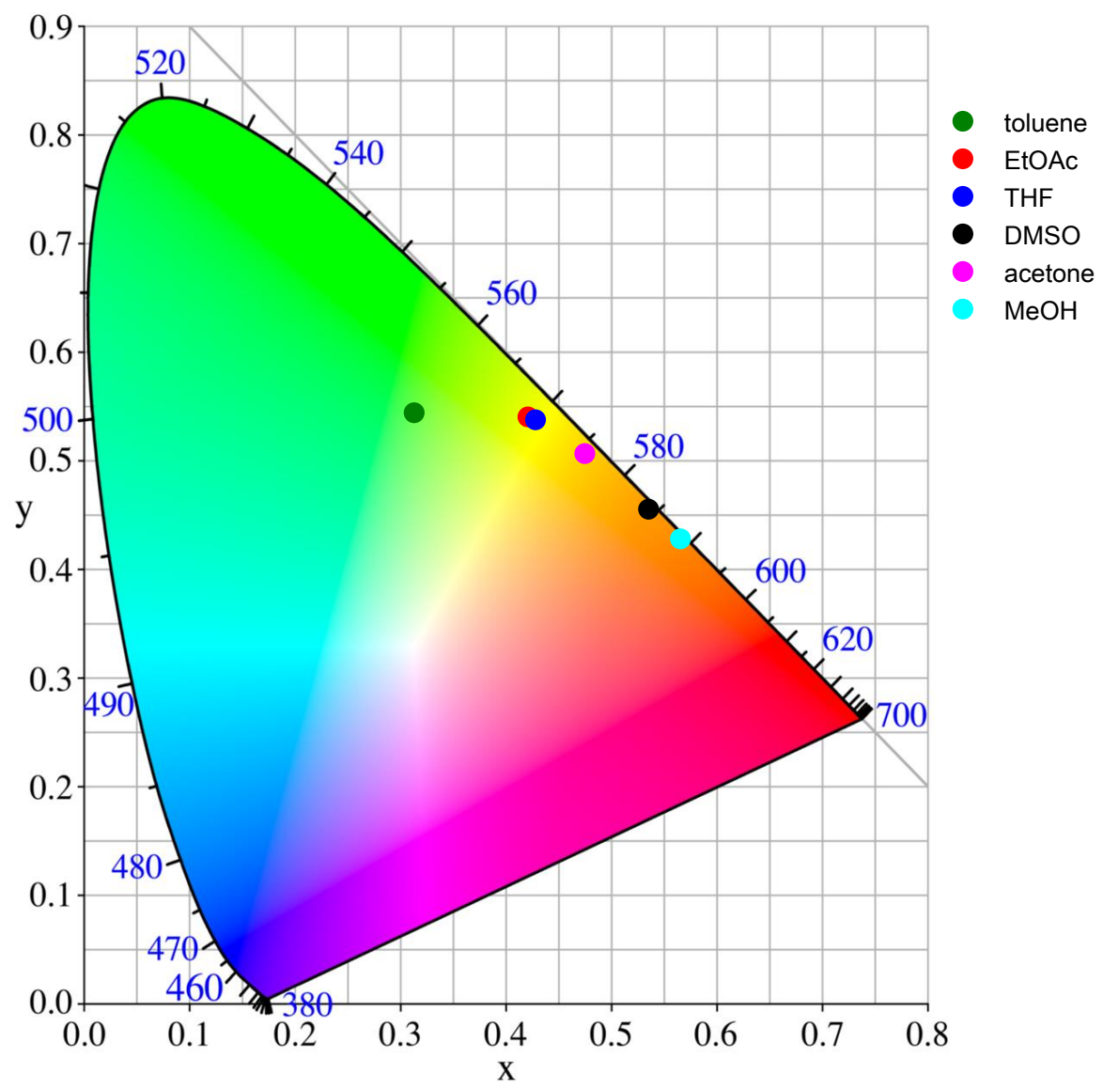

Figure S19. Chromaticity diagrams for 4 in different solvents. 


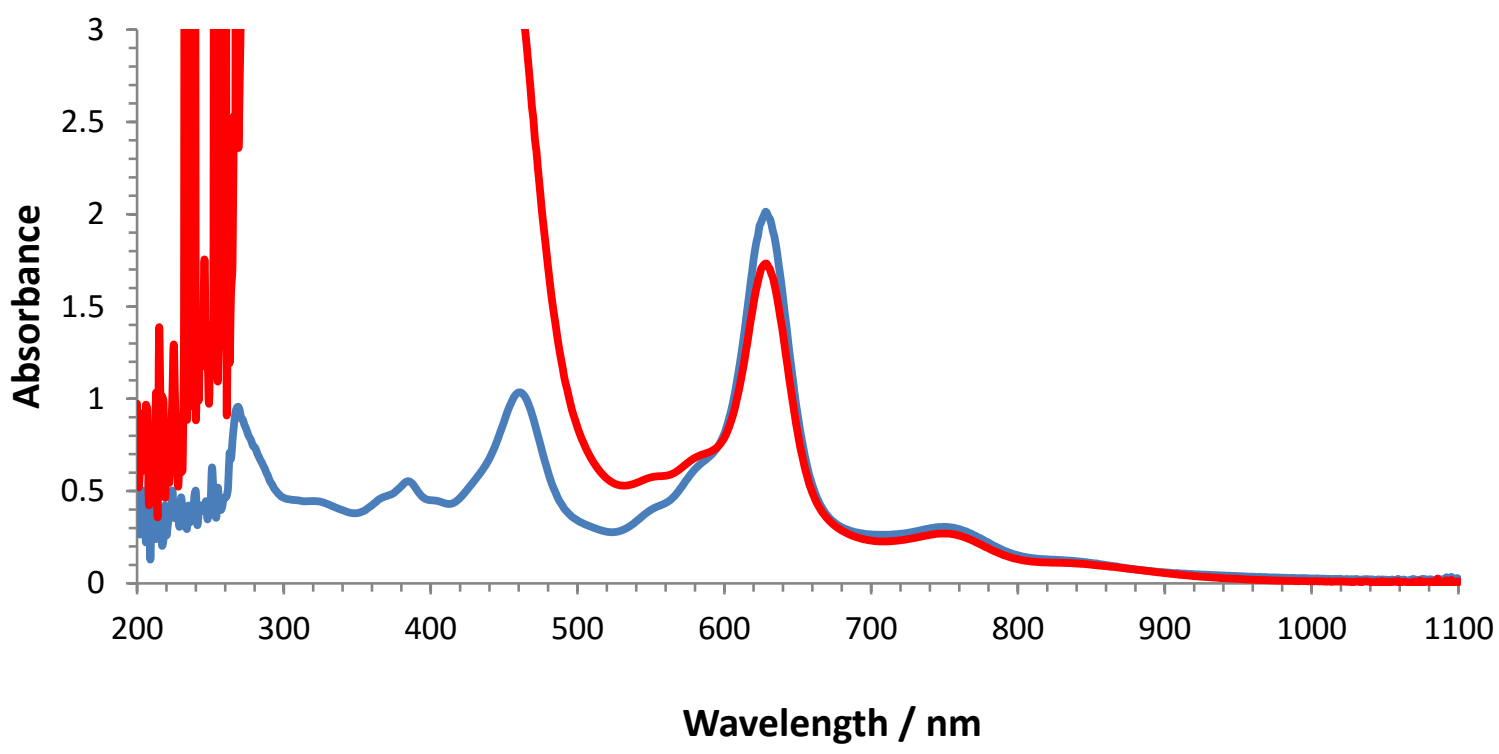

Figure S20. Reversibility of chemical reduction investigated for 11-Zn. Blue line, initial solution; red line, solution obtained after reduction with sodium anthracenide (10 mM in THF) followed by reoxidation with excess diiodine ( $30 \mathrm{mM}$ in THF). 


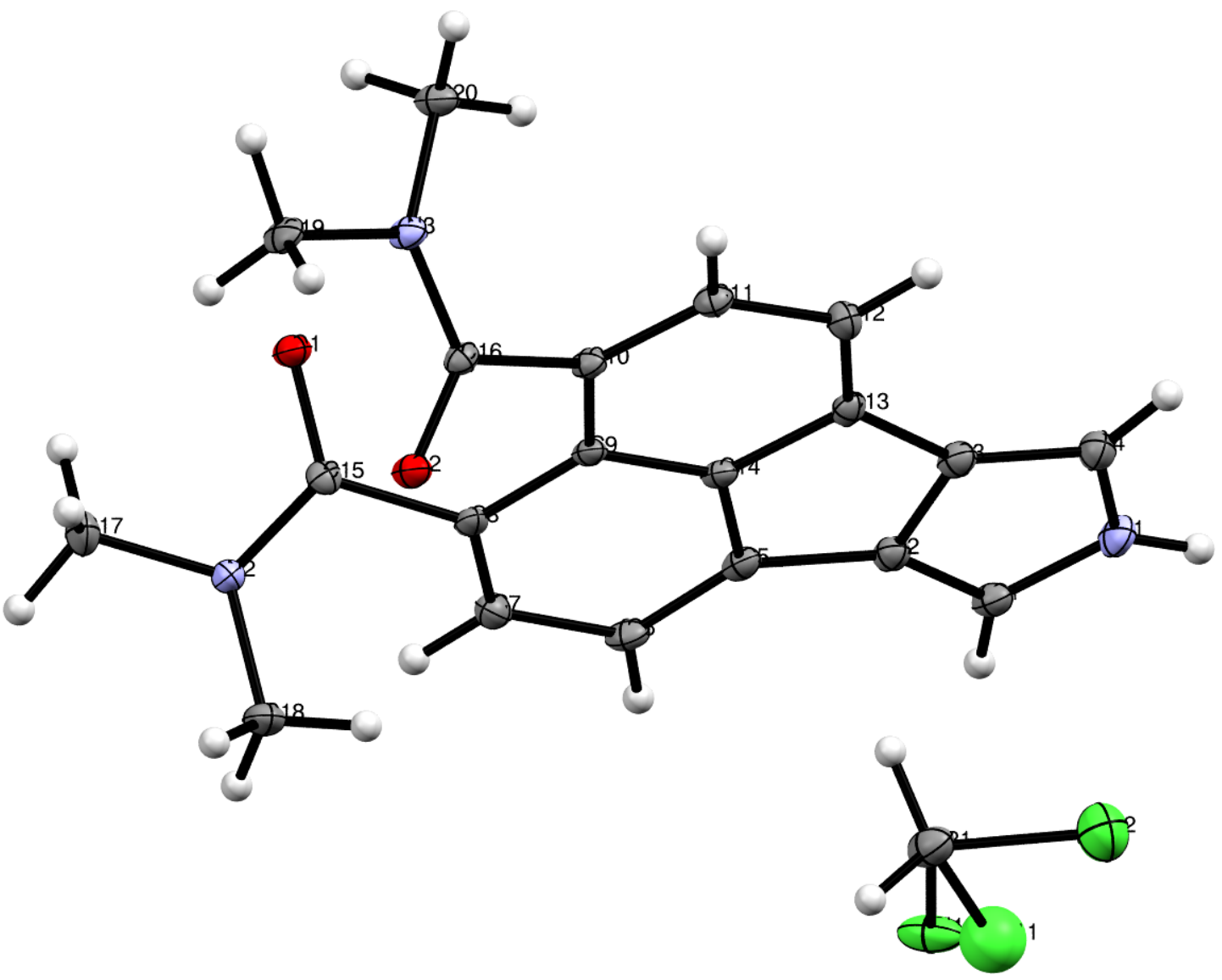

Figure S21. Molecular structure of $\mathbf{2} \cdot \mathbf{C H}_{\mathbf{2}} \mathrm{Cl}_{\mathbf{2}}$.

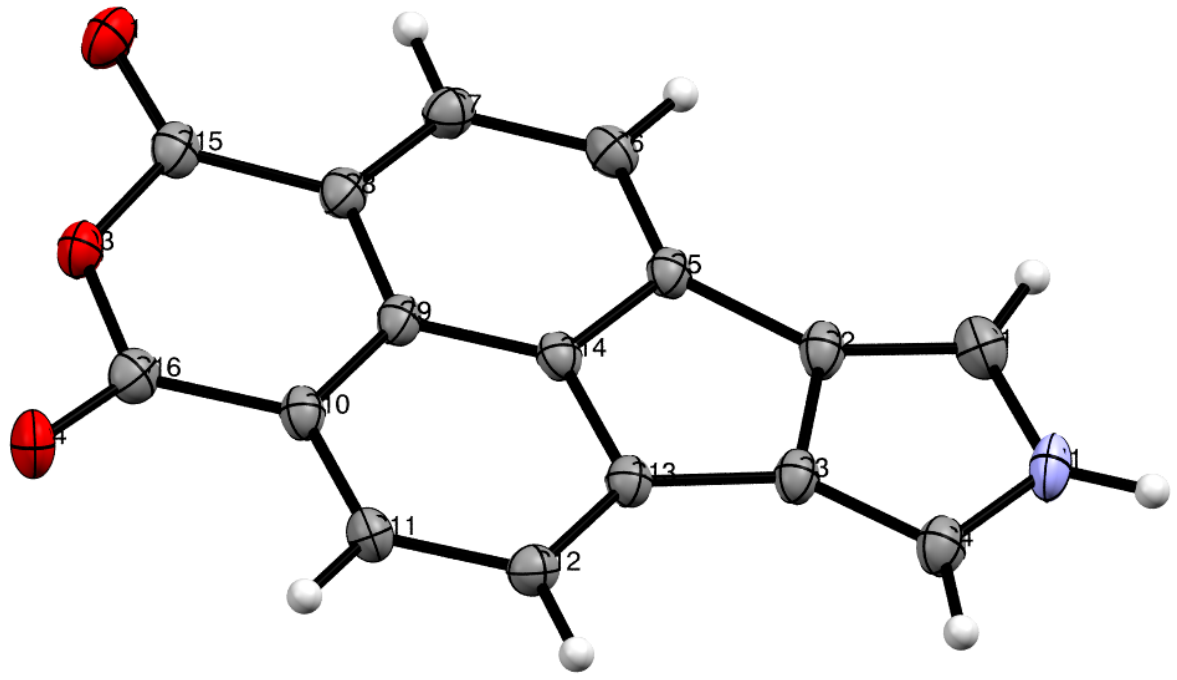

Figure S22. Molecular structure of 5. 


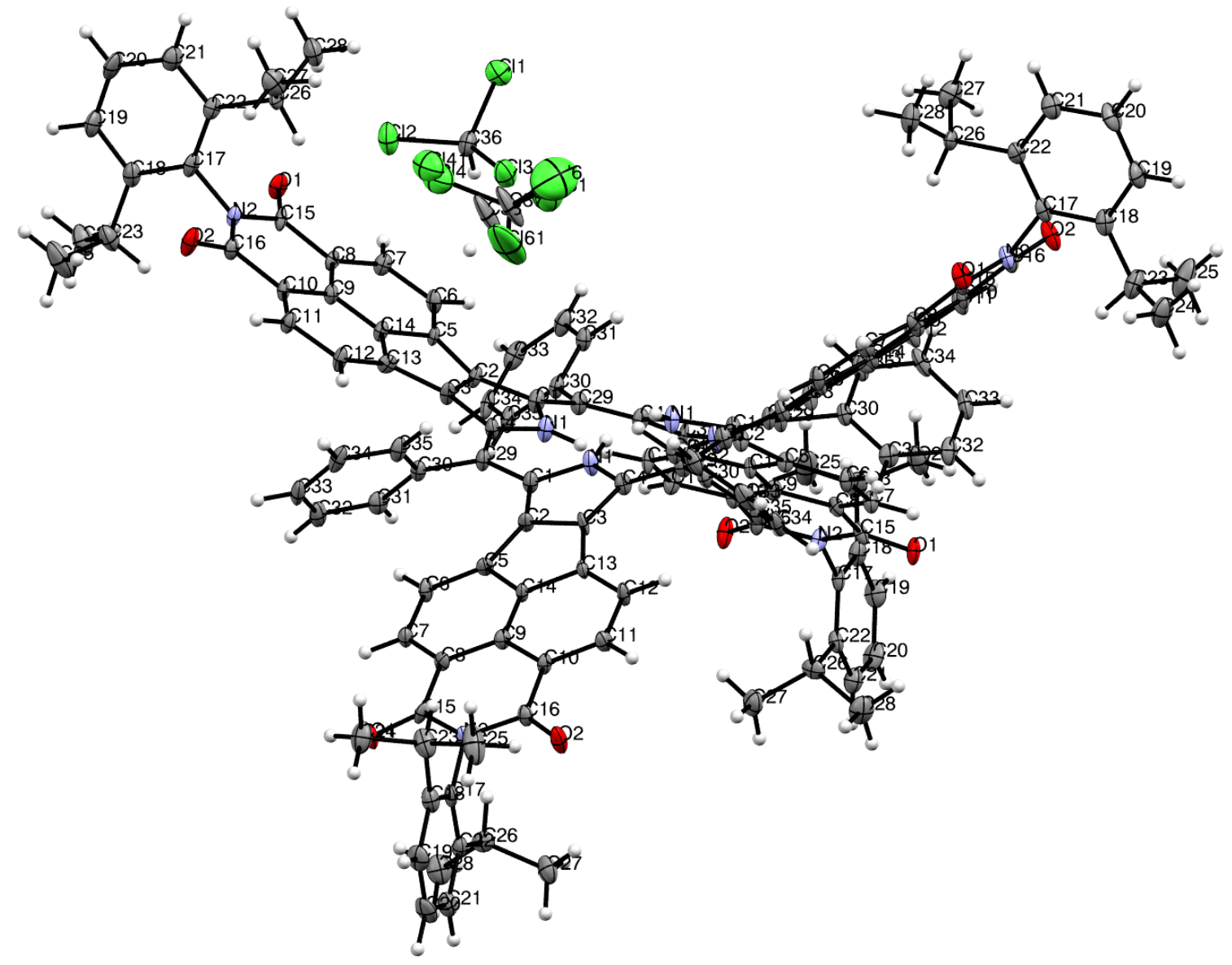

Figure S23. Molecular structure of $\mathbf{1 1}-\mathrm{H}_{2} \cdot \mathbf{6} \mathrm{CHCl}_{3}$. 


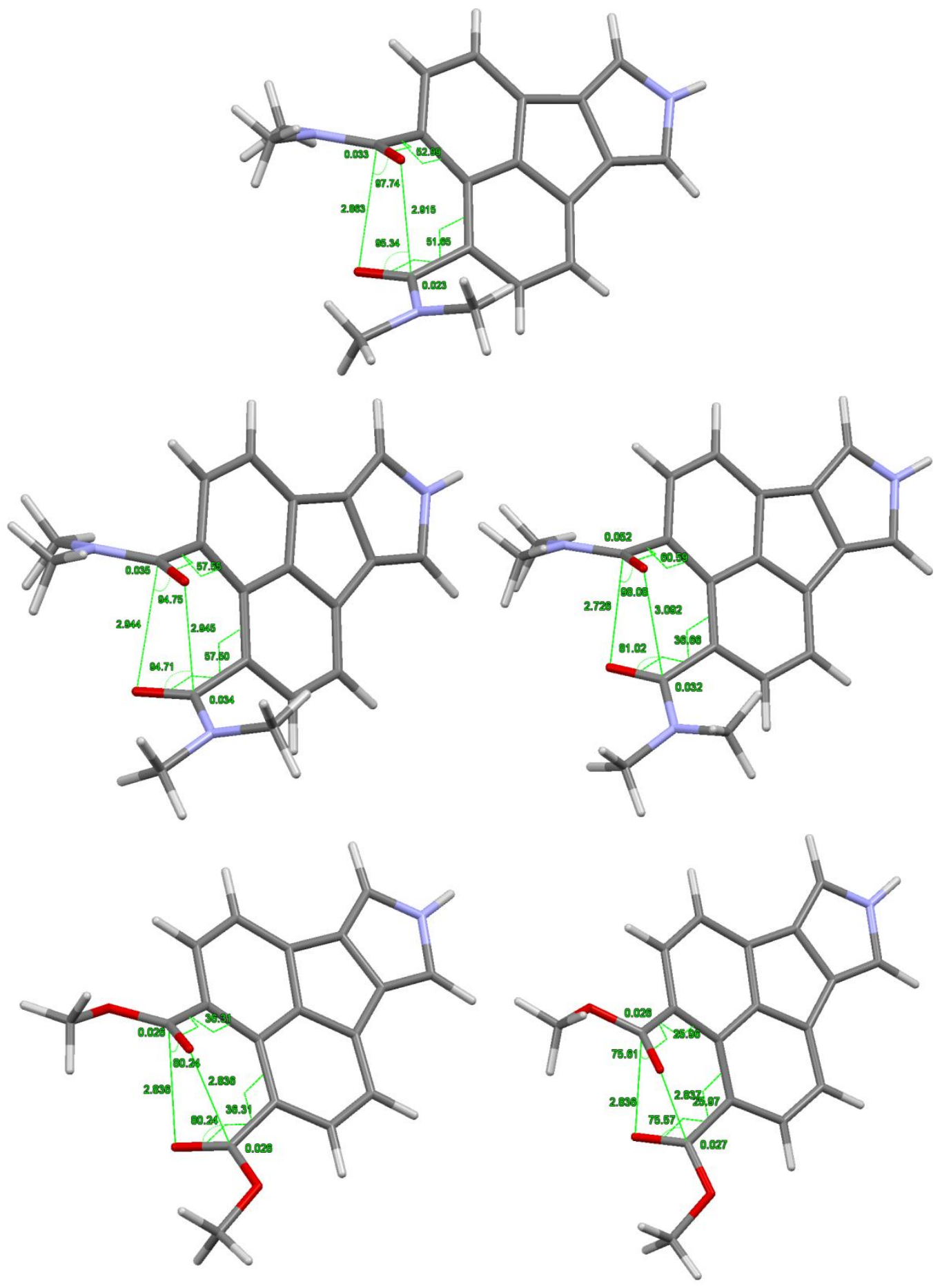

Figure S24. Geometrical parameters: ${ }^{23}$ carbonyl pyramidalizations $\Delta(\AA), \mathrm{O}=\mathrm{C} \cdots \mathrm{O}$ distances $d(\AA)$, and $\mathrm{O}=\mathrm{C} \cdots \mathrm{O}$ angles $\vartheta(\mathrm{deg})$ of the intramolecular amide/ester interactions as seen in the solid state structure of $\mathbf{2}$ (top), and in the DFT structures of $\mathbf{2}$ (middle left S0, middle right S1), and $\mathbf{3}$ (bottom left S0, bottom right S1). CCCO torsions are also indicated. S0 states were optimized using the $\mathrm{PCM}(\mathrm{DMSO}) / \mathrm{B} 3 \mathrm{LYP} / 6-31 \mathrm{G}(\mathrm{d}, \mathrm{p})$ level of theory. S1 states were optimized at the same level of theory using the TDA formalism and equilibrium solvation. 


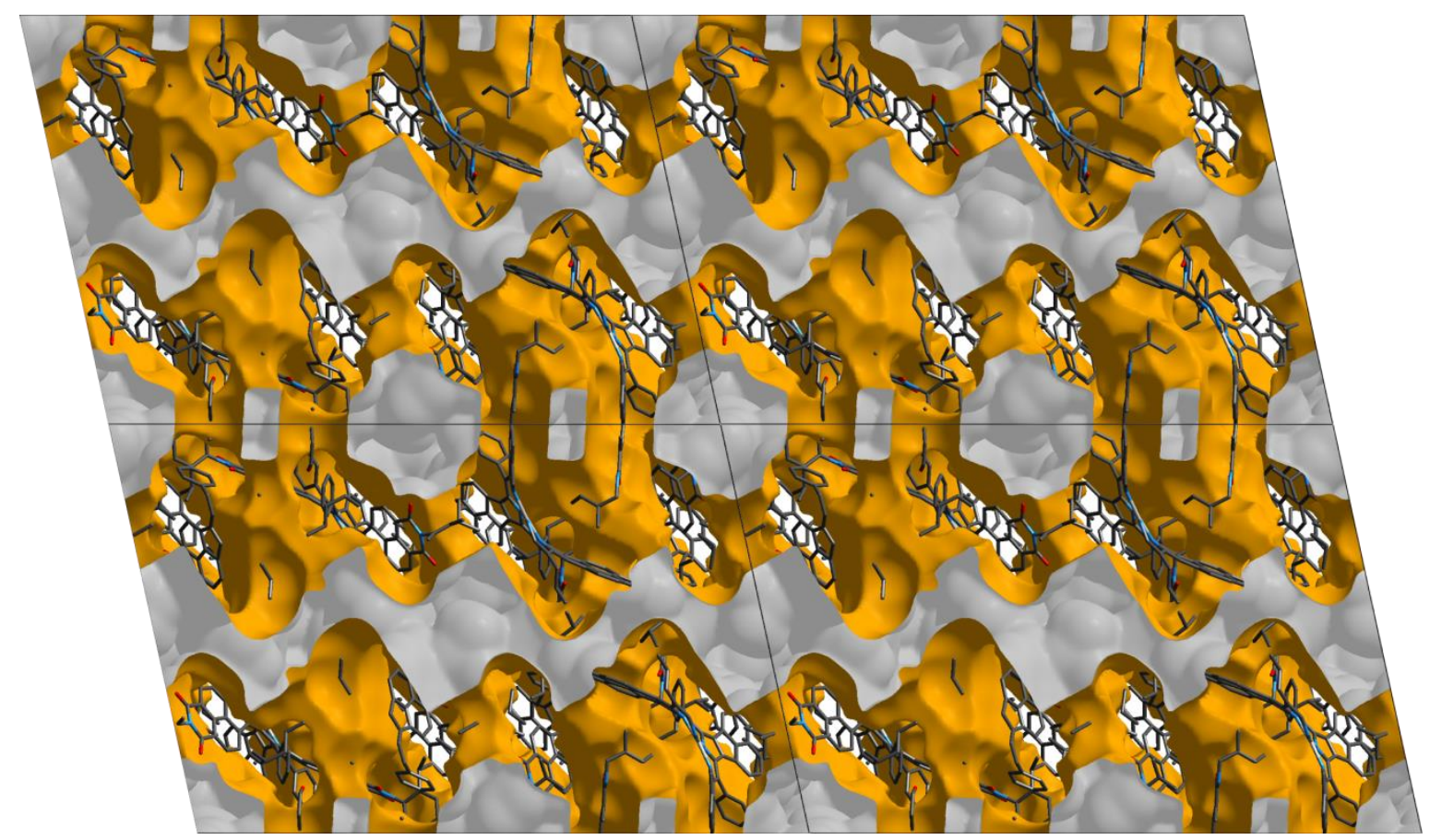

Figure S25. Channel structure (procrystal electron density, 0.0003 au isosurface, solvent molecules removed for calculation) for the $C 2 / c$ phase of $11-\mathrm{Zn}$ ( view along $b$ ). 


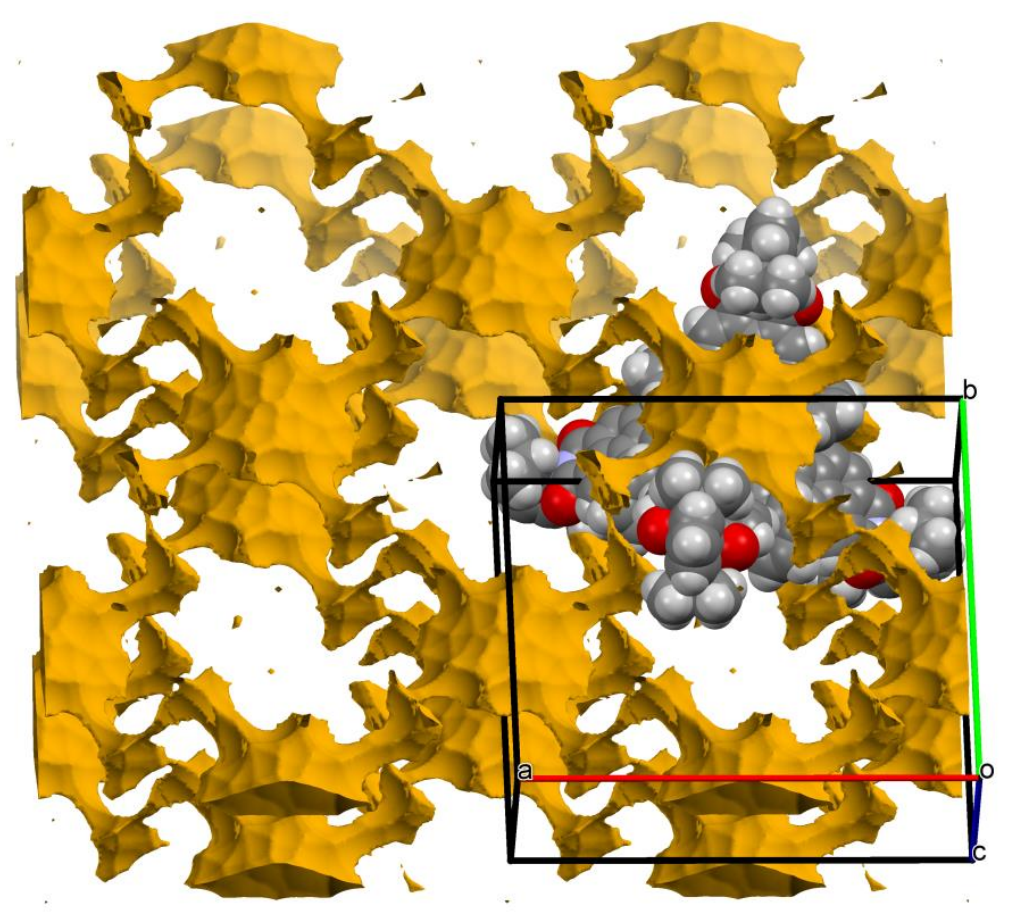

Figure S26. Solvent accessible surface for the tetragonal polymorph of 11- $\mathrm{H}_{2}$ obtained after removal of solvent molecules, calculated using Mercury 3.7. Probe radius: $1.3 \AA$, grid spacing $0.2 \AA$.

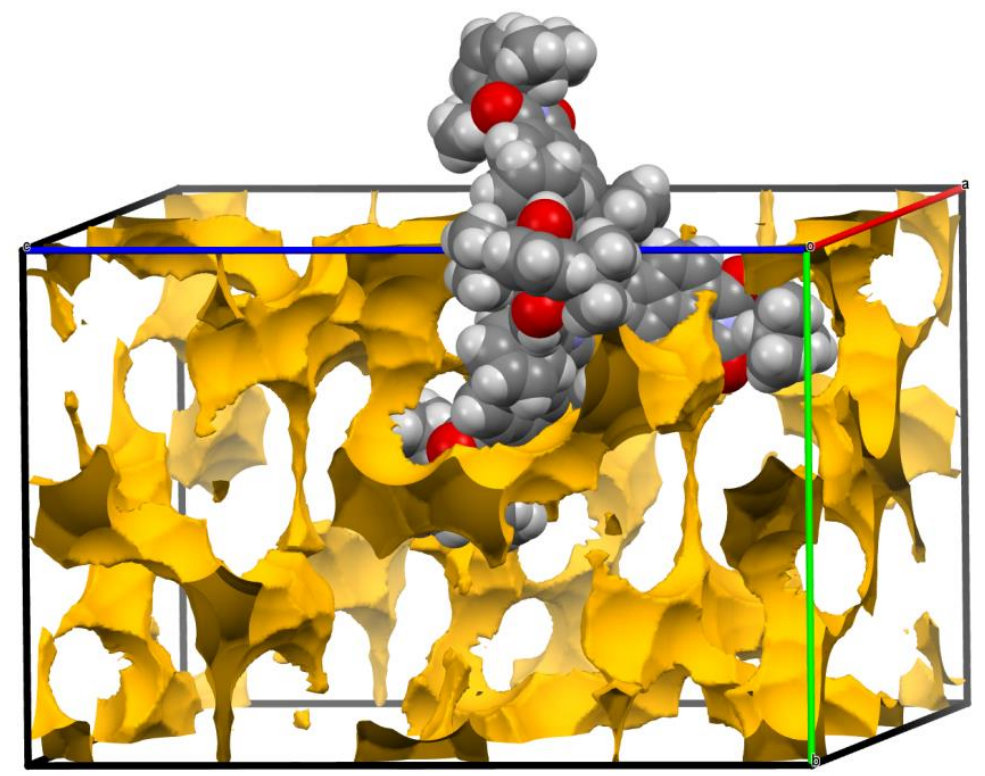

Figure S27. Solvent accessible surface for the tetragonal polymorph of 11-Zn obtained after removal of solvent molecules, calculated using Mercury 3.7. Probe radius: $1.8 \AA$, grid spacing $0.2 \AA$. 


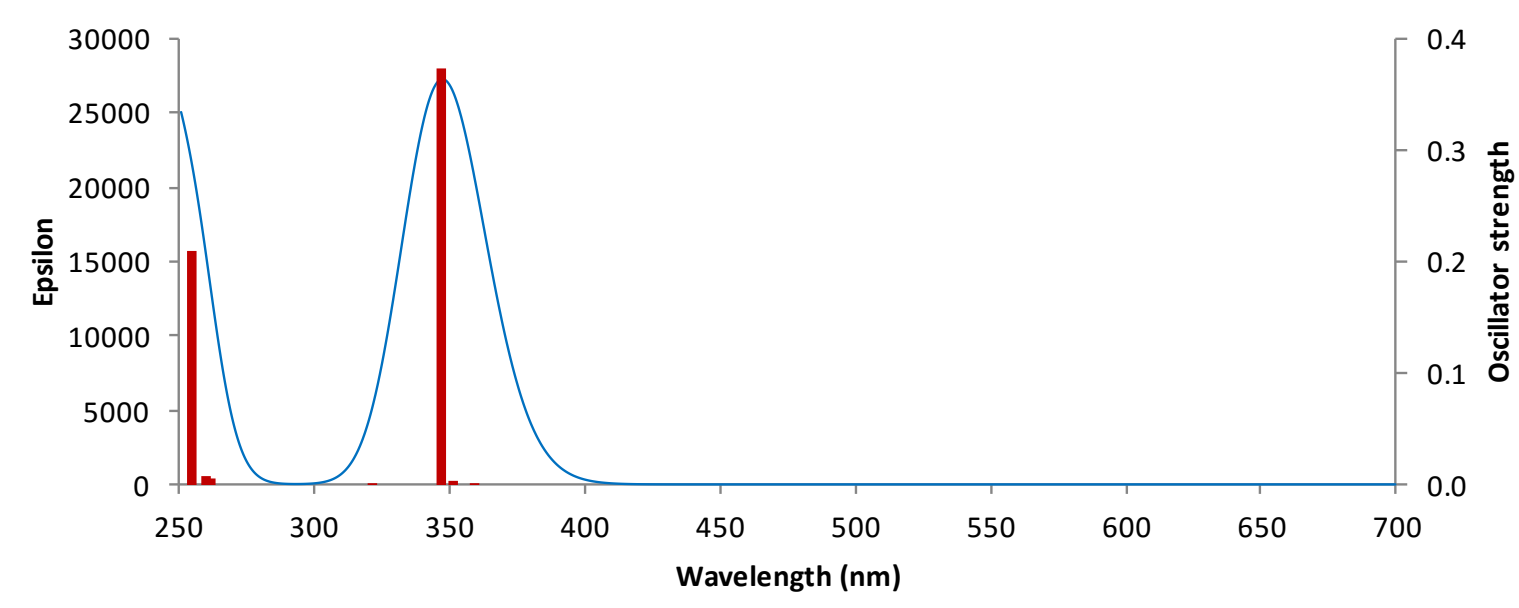

Figure S28. Time-dependent DFT electronic spectrum of 1 (TDA/PCM(DMSO)/B3LYP/6-31G(d,p)).

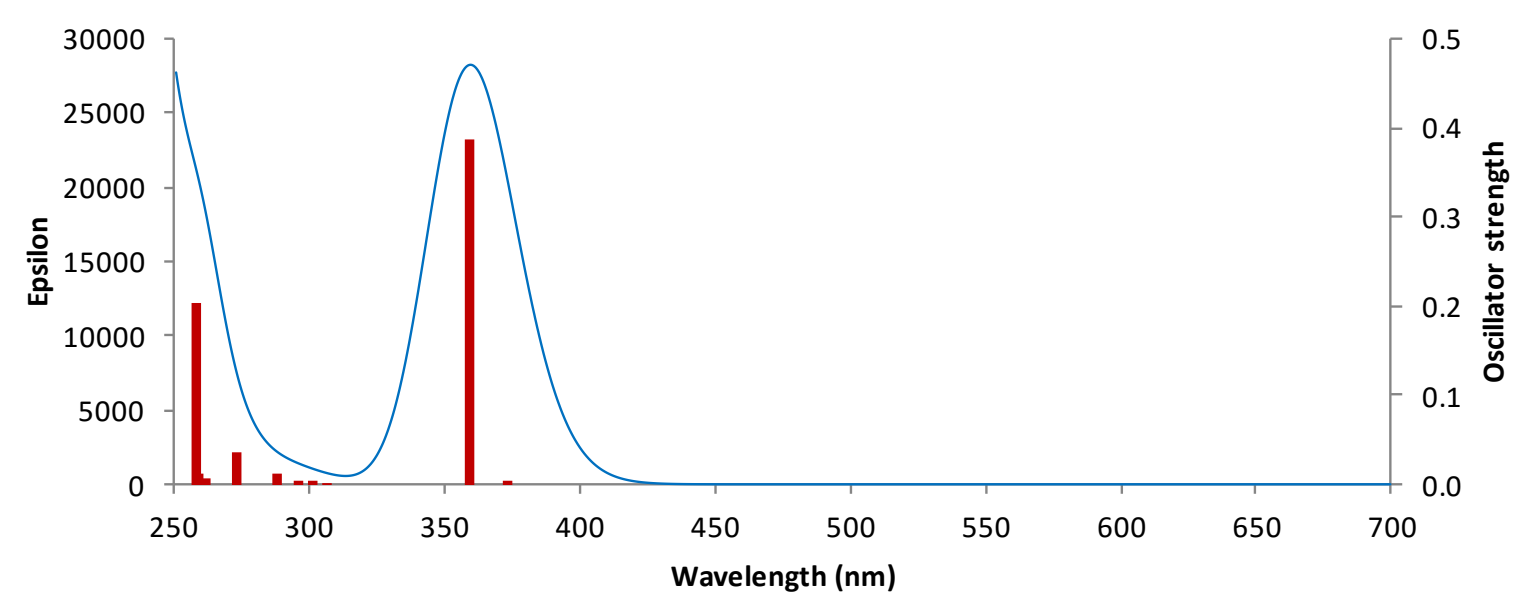

Figure S29. Time-dependent DFT electronic spectrum of 2 (TDA/PCM(DMSO)/B3LYP/6-31G(d,p)).

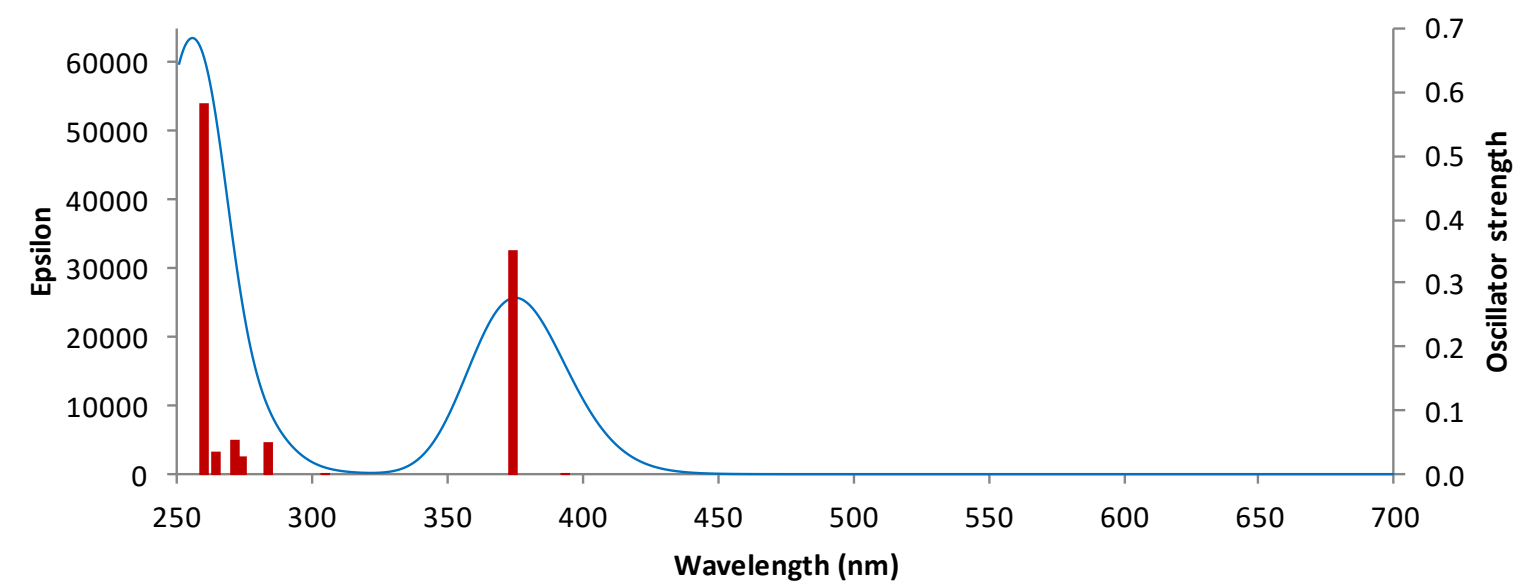

Figure S30. Time-dependent DFT electronic spectrum of 3 (TDA/PCM(DMSO)/B3LYP/6-31G(d,p)).. 


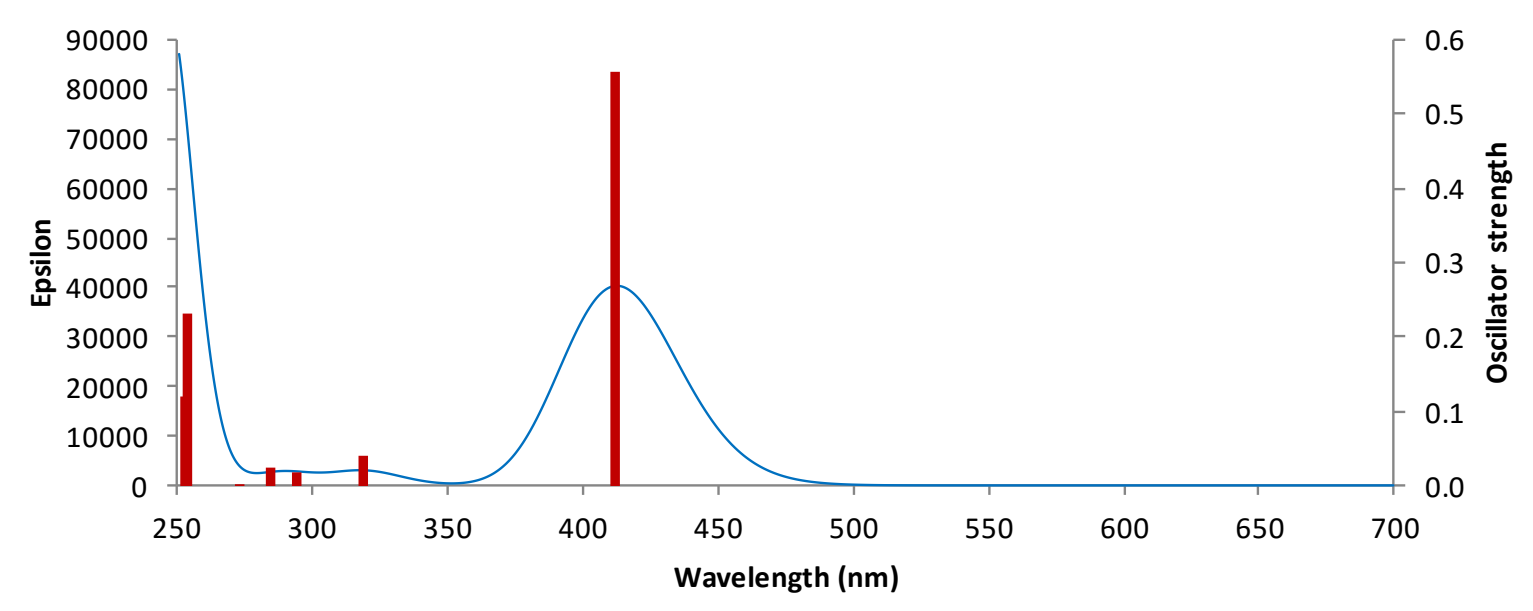

Figure S31. Time-dependent DFT electronic spectrum of 4 (TDA/PCM(DMSO)/B3LYP/6-31G(d,p)).

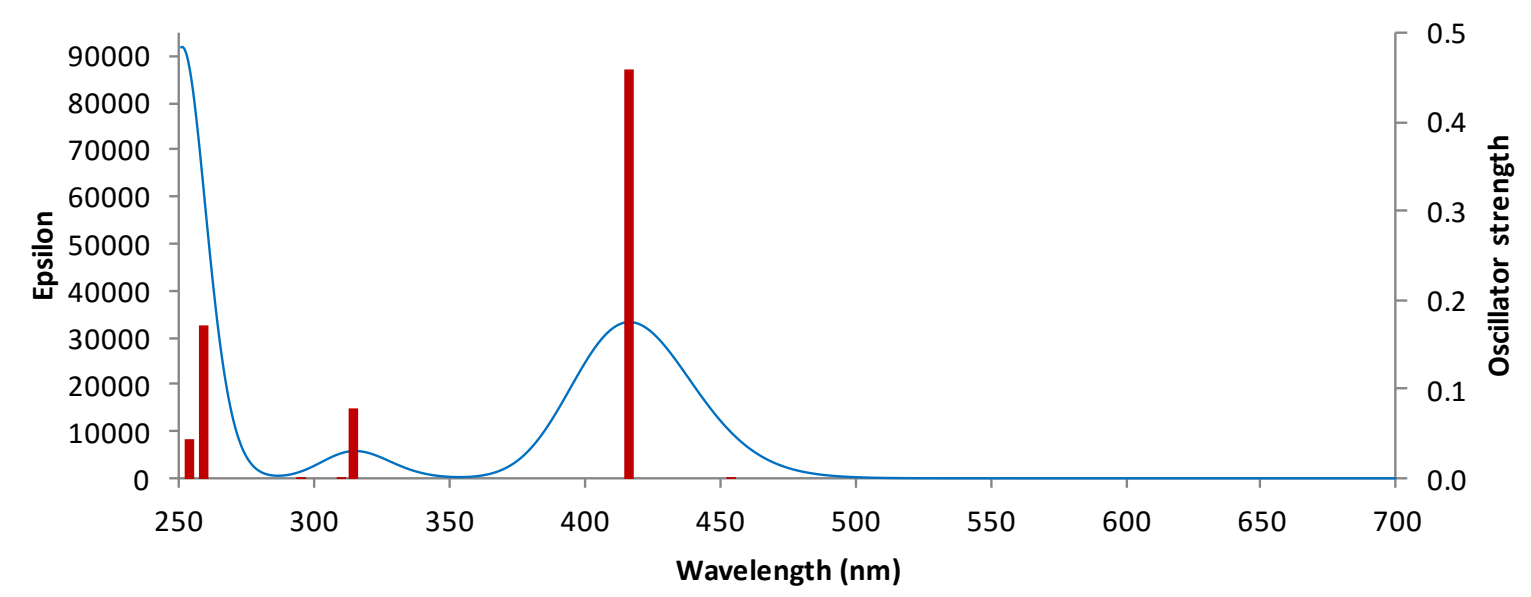

Figure S32. Time-dependent DFT electronic spectrum of 5 (TDA/PCM(DMSO)/B3LYP/6-31G(d,p))..

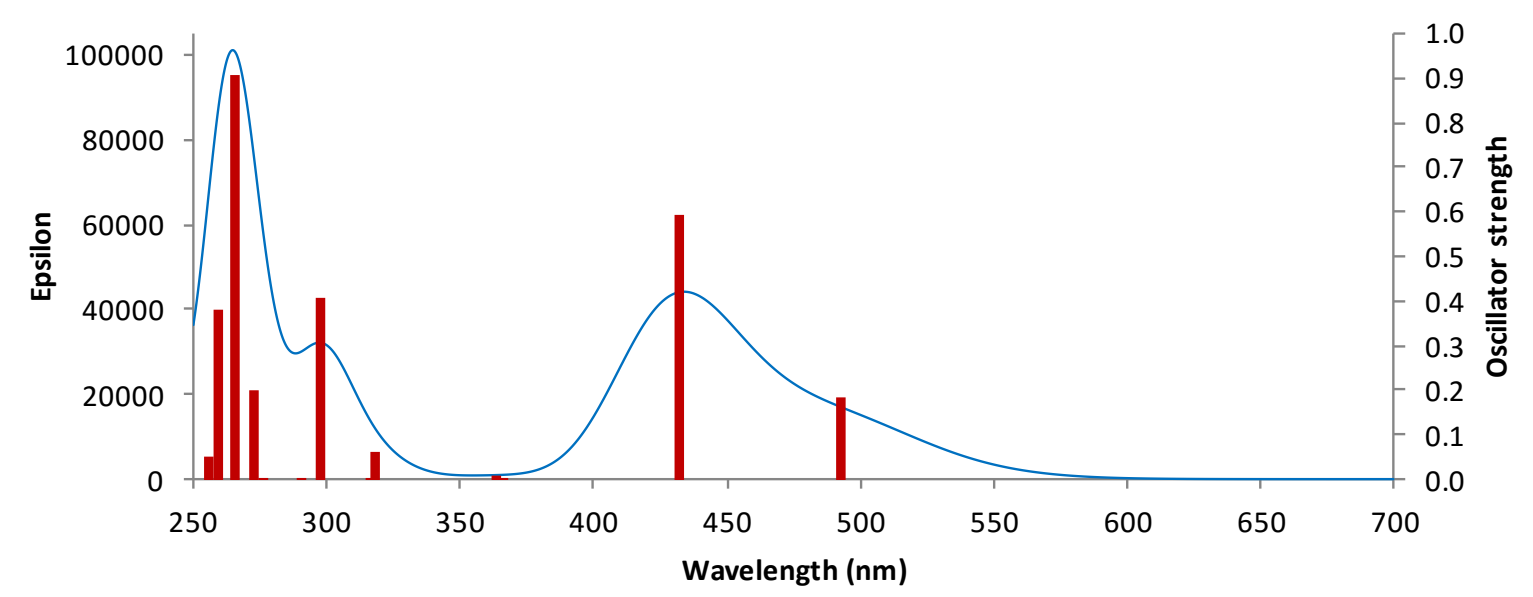

Figure S33. Time-dependent DFT electronic spectrum of 6 (TDA/PCM(DMSO)/B3LYP/6-31G(d,p)). 


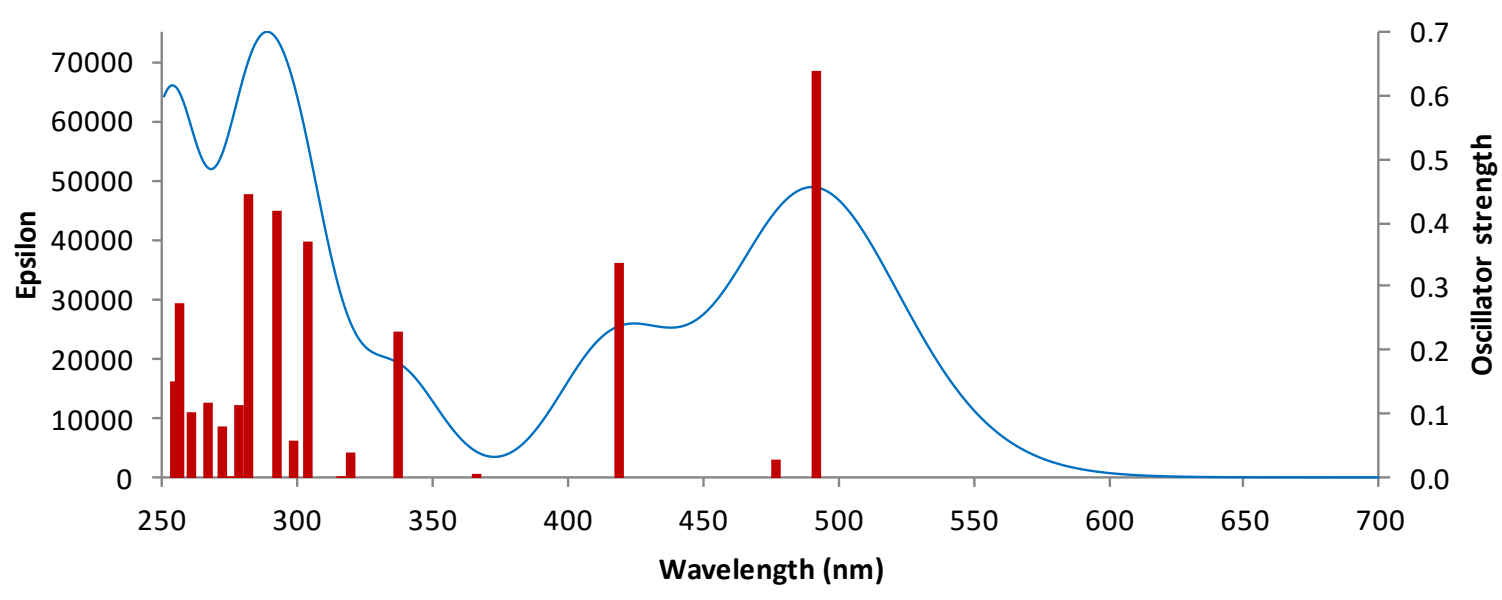

Figure S34. Time-dependent DFT electronic spectrum of 7 (TDA/PCM(DMSO)/B3LYP/6-31G(d,p))..

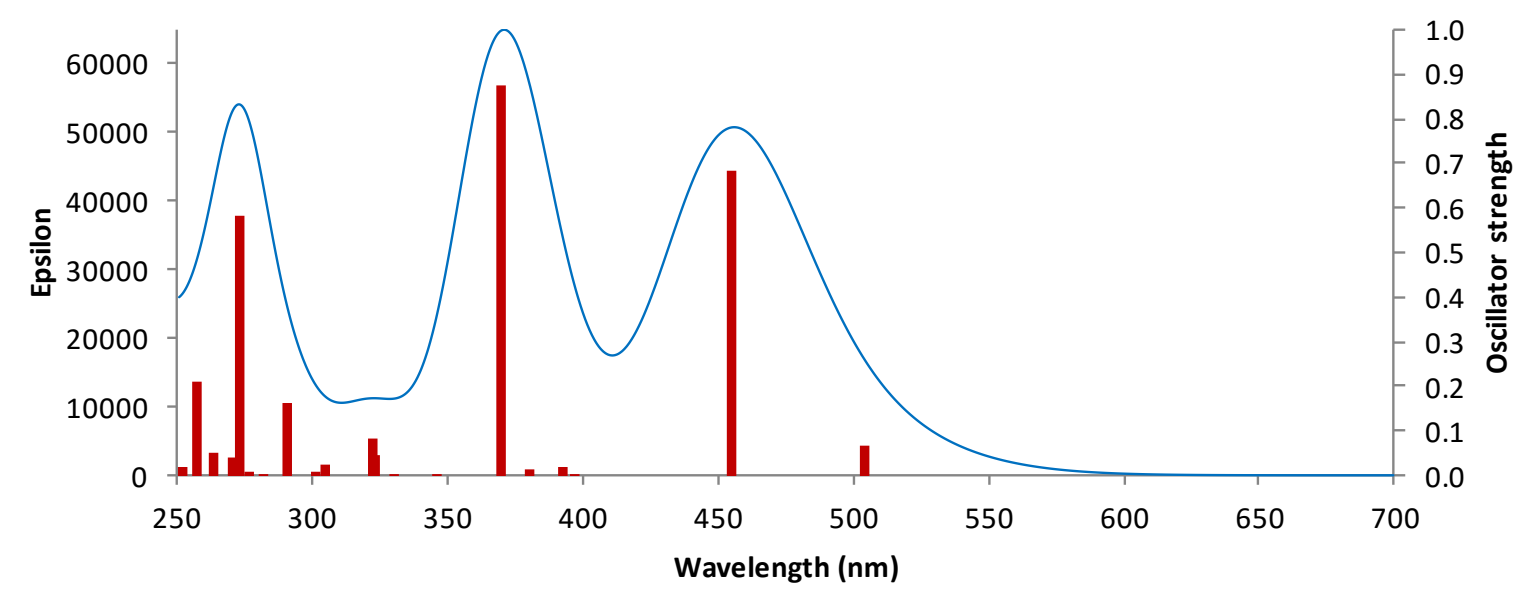

Figure S35. Time-dependent DFT electronic spectrum of 8 (TDA/PCM(DMSO)/B3LYP/6-31G(d,p)).

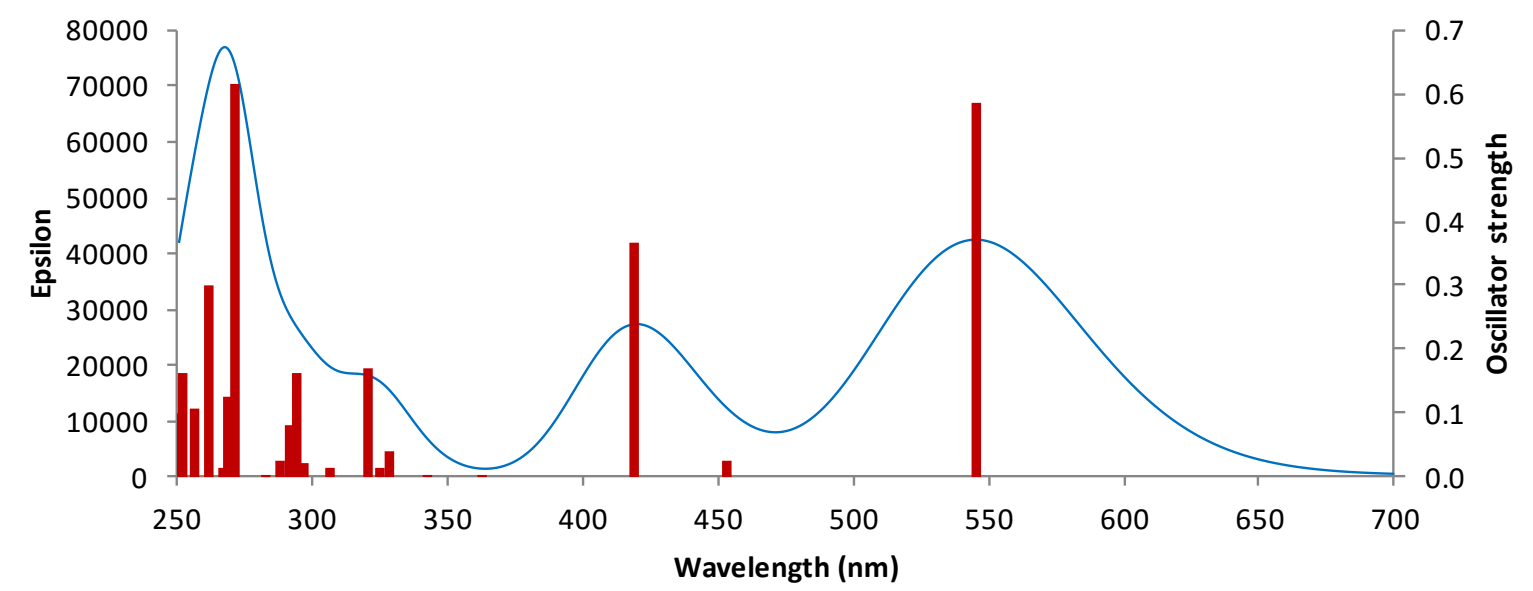

Figure S36. Time-dependent DFT electronic spectrum of 9 (TDA/PCM(DMSO)/B3LYP/6-31G(d,p)). 


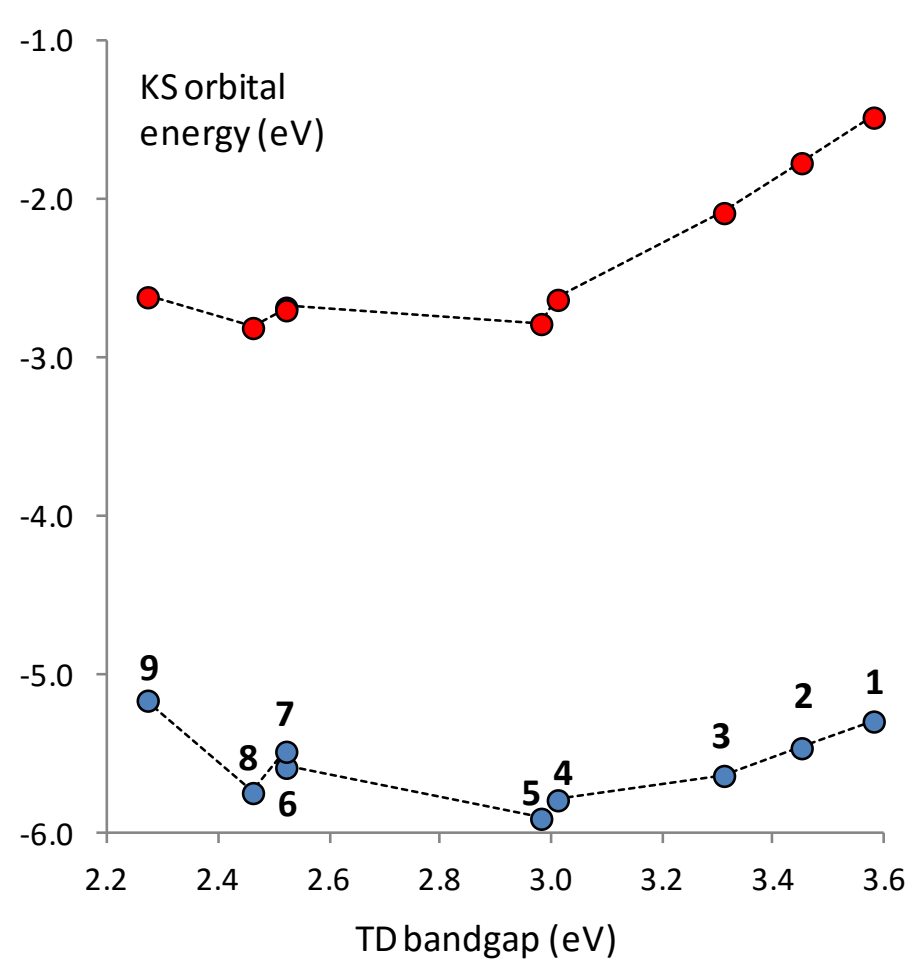

Figure S37. Kohn-Sham HOMO (blue) and LUMO (red) DFT energies for pyrroles 1-9 plotted as a function of TD-DFT bandgaps. 


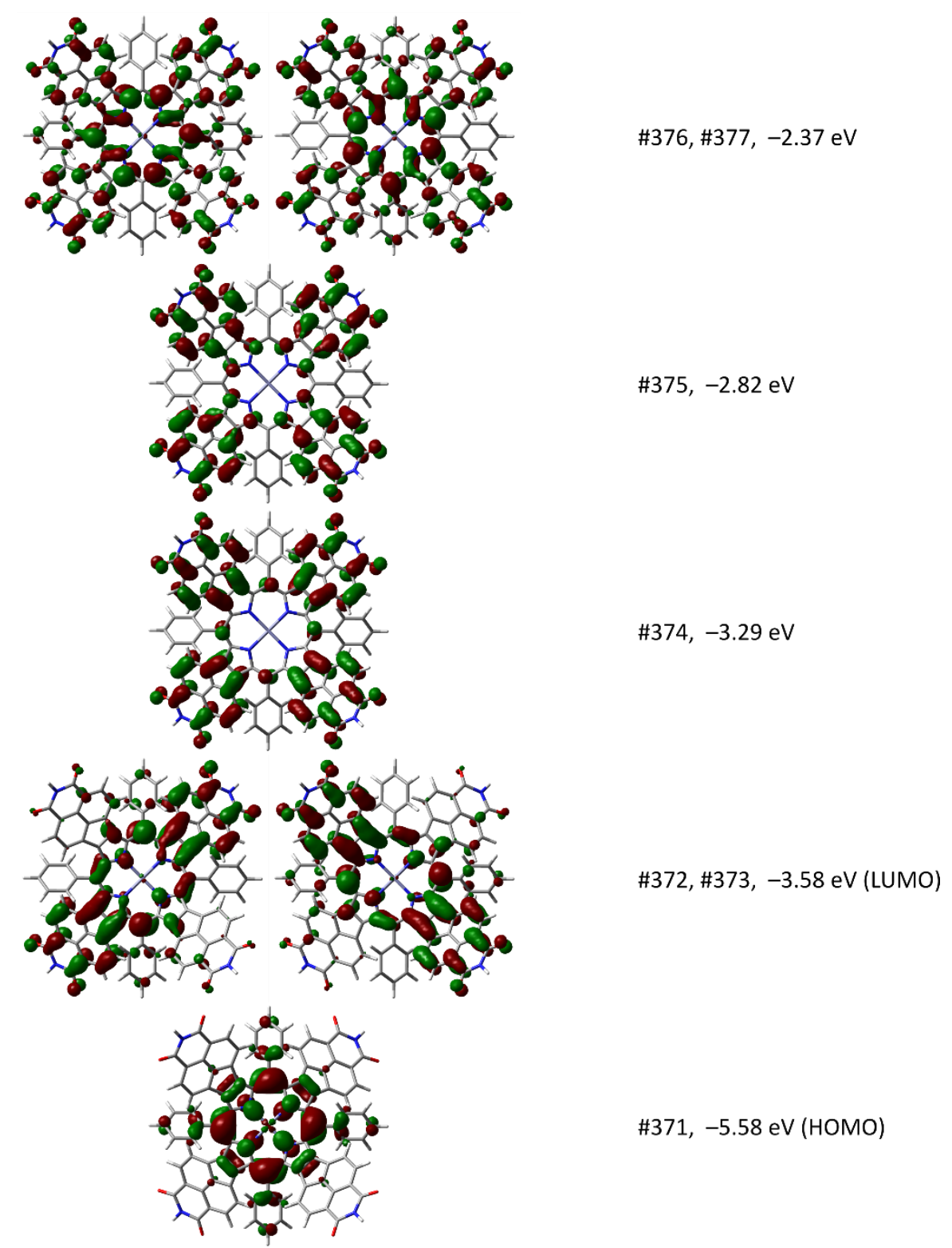

Figure S38. Kohn-Sham frontier orbitals for 11'-Zn (B3LYP/6-31G(d,p) level of theory) . 
Additional Tables 
Table S1. Crystal data and structure refinement for $\mathbf{2} \cdot \mathbf{C H}_{\mathbf{2}} \mathrm{Cl}_{2}$.

Identification code

Empirical formula

Formula weight

Temperature

Wavelength

Crystal system

Space group

Unit cell dimensions

Volume

$\mathrm{Z}$

Density (calculated)

Absorption coefficient

$\mathrm{F}(000)$

Crystal size

Theta range for data collection

Index ranges

Reflections collected

Independent reflections

Completeness to theta $=25.500^{\circ}$

Absorption correction

Max. and min. transmission

Refinement method

Data / restraints / parameters

Goodness-of-fit on $\mathrm{F}^{2}$

Final R indices [I $>2 \operatorname{sigma}(\mathrm{I})]$

$\mathrm{R}$ indices (all data)

Absolute structure parameter

Extinction coefficient

Largest diff. peak and hole hz123a

$\mathrm{C} 21 \mathrm{H} 21 \mathrm{Cl} 2 \mathrm{~N} 3 \mathrm{O} 2$

418.31

$80(2) \mathrm{K}$

$0.71073 \AA$

Monoclinic

P21

$a=7.1366(18) \AA$ $\alpha=90^{\circ}$.

$\mathrm{b}=12.004(3) \AA$ $\beta=102.43(2)^{\circ}$.

$\mathrm{c}=11.688(3) \AA$ $\gamma=90^{\circ}$.
977.8(4) $\AA^{3}$

2

$1.421 \mathrm{Mg} / \mathrm{m}^{3}$

$0.355 \mathrm{~mm}^{-1}$

436

$0.450 \times 0.230 \times 0.100 \mathrm{~mm}^{3}$

2.923 to $30.601^{\circ}$.

$-5<=\mathrm{h}<=10,-14<=\mathrm{k}<=17,-16<=\mathrm{l}<=16$

6497

$4650[\mathrm{R}(\mathrm{int})=0.0247]$

$99.8 \%$

Analytical

0.968 and 0.902

Full-matrix least-squares on $\mathrm{F}^{2}$

4650 / 1 / 262

1.047

$\mathrm{R} 1=0.0348, \mathrm{wR} 2=0.0844$

$\mathrm{R} 1=0.0376, \mathrm{wR} 2=0.0863$

$0.02(3)$

$\mathrm{n} / \mathrm{a}$

0.33 and -0.21 e. $\AA^{-3}$ 
Table S2. Crystal data and structure refinement for $\mathbf{5 .}$

Identification code

Empirical formula

Formula weight

Temperature

Wavelength

Crystal system

Space group

Unit cell dimensions

Volume

$\mathrm{Z}$

Density (calculated)

Absorption coefficient

$\mathrm{F}(000)$

Crystal size

Theta range for data collection

Index ranges

Reflections collected

Independent reflections

Completeness to theta $=25.500^{\circ}$

Absorption correction

Refinement method

Data / restraints / parameters

Goodness-of-fit on $\mathrm{F}^{2}$

Final $\mathrm{R}$ indices [I>2sigma(I)]

$\mathrm{R}$ indices (all data)

Extinction coefficient

Largest diff. peak and hole
HZ103

C16 H7 N O3

261.23

80(2) K

$0.71073 \AA$

Triclinic

P-1

$\mathrm{a}=7.2916(15) \AA$

$\alpha=88.49(4)^{\circ}$.

$\mathrm{b}=8.7529(16) \AA$

$\beta=69.51(5)^{\circ}$.

$\mathrm{c}=9.7443(17) \AA$

$\gamma=67.04(5)^{\circ}$.
$532.0(3) \AA^{3}$

2

$1.631 \mathrm{Mg} / \mathrm{m}^{3}$

$0.115 \mathrm{~mm}^{-1}$

268

$0.456 \times 0.050 \times 0.030 \mathrm{~mm}^{3}$

3.177 to $30.480^{\circ}$.

$-9<=\mathrm{h}<=7,-12<=\mathrm{k}<=12,-13<=\mathrm{l}<=8$

4297

$2932[\mathrm{R}(\mathrm{int})=0.0300]$

$99.8 \%$

NONE

Full-matrix least-squares on $\mathrm{F}^{2}$

2932 / 0 / 181

1.048

$\mathrm{R} 1=0.0675, \mathrm{wR} 2=0.1526$

$\mathrm{R} 1=0.1073, \mathrm{wR} 2=0.1820$

$\mathrm{n} / \mathrm{a}$

0.341 and -0.338 e. $\AA^{-3}$ 


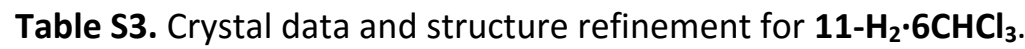

Identification code

Empirical formula

Formula weight

Temperature

Wavelength

Crystal system

Space group

Unit cell dimensions

Volume

$\mathrm{Z}$

Density (calculated)

Absorption coefficient

$\mathrm{F}(000)$

Crystal size

Theta range for data collection

Index ranges

Reflections collected

Independent reflections

Completeness to theta $=25.500^{\circ}$

Refinement method

Data / restraints / parameters

Goodness-of-fit on $\mathrm{F}^{2}$

Final $\mathrm{R}$ indices $[\mathrm{I}>2 \operatorname{sigma}(\mathrm{I})]$

$\mathrm{R}$ indices (all data)

Absolute structure parameter

Extinction coefficient

Largest diff. peak and hole
HZ145CA

C146 H112 Cl18 N8 O8

2744.53

80(2) K

$0.71073 \AA$

Tetragonal

I-4

$\mathrm{a}=28.178(8) \AA$

$\alpha=90^{\circ}$.

$\mathrm{b}=28.178(8) \AA$

$\beta=90^{\circ}$.

$\mathrm{c}=8.7335(18) \AA$

$\gamma=90^{\circ}$

6934(4) $\AA^{3}$

2

$1.314 \mathrm{Mg} / \mathrm{m}^{3}$

$0.414 \mathrm{~mm}^{-1}$

2828

$0.800 \times 0.080 \times 0.050 \mathrm{~mm}^{3}$

2.838 to $30.615^{\circ}$.

$-33<=\mathrm{h}<=39,-35<=\mathrm{k}<=25,-12<=\mathrm{l}<=11$

10329

$7831[\mathrm{R}(\mathrm{int})=0.0420]$

$99.6 \%$

Full-matrix least-squares on $\mathrm{F}^{2}$

$7831 / 19 / 443$

1.047

$\mathrm{R} 1=0.0746, \mathrm{wR} 2=0.1733$

$\mathrm{R} 1=0.1072, \mathrm{wR} 2=0.1941$

$0.43(11)$

$\mathrm{n} / \mathrm{a}$

0.792 and -0.440 e. $\AA^{-3}$ 
Table S4. Crystal data and structure refinement for $11-\mathrm{Zn} \cdot 2.25 \mathrm{CH}_{2} \mathrm{Cl}_{2} \cdot 5.75 \mathrm{C}_{6} \mathrm{H}_{14}$.

Identification code

Empirical formula

Formula weight

Temperature

Wavelength

Crystal system

Space group

Unit cell dimensions

Volume

$\mathrm{Z}$

Density (calculated)

Absorption coefficient

$\mathrm{F}(000)$

Crystal size

Theta range for data collection

Index ranges

Reflections collected

Independent reflections

Completeness to theta $=25.500^{\circ}$

Absorption correction

Max. and min. transmission

Refinement method

Data / restraints / parameters

Goodness-of-fit on $\mathrm{F}^{2}$

Final $\mathrm{R}$ indices [I $>2 \operatorname{sigma}(\mathrm{I})]$

$\mathrm{R}$ indices (all data)

Extinction coefficient

Largest diff. peak and hole
HZ145ZNA

C176.75 H189 Cl4.50 N8 O8 Zn

2778.24

80(2) K

$0.71073 \AA$

Monoclinic

$\mathrm{C} 2 / \mathrm{c}$

$\begin{array}{ll}\mathrm{a}=29.190(10) \AA & \alpha=90^{\circ} . \\ \mathrm{b}=28.114(9) \AA & \beta=102.19(5)^{\circ} . \\ \mathrm{c}=42.68(3) \AA & \gamma=90^{\circ} .\end{array}$

$34236(30) \AA^{3}$

8

$1.078 \mathrm{Mg} / \mathrm{m}^{3}$

$0.268 \mathrm{~mm}^{-1}$

11808

$0.500 \times 0.400 \times 0.060 \mathrm{~mm}^{3}$

2.780 to $25.500^{\circ}$.

$-34<=\mathrm{h}<=35,-34<=\mathrm{k}<=21,-51<=\mathrm{l}<=21$

61986

$31844[\mathrm{R}($ int $)=0.1539]$

$99.8 \%$

Analytical

0.985 and 0.926

Full-matrix least-squares on $\mathrm{F}^{2}$

31844 / 208 / 1610

1.175

$\mathrm{R} 1=0.1670, \mathrm{wR} 2=0.3408$

$\mathrm{R} 1=0.3707, \mathrm{wR} 2=0.4336$

$\mathrm{n} / \mathrm{a}$

0.907 and -0.431 e. $\AA^{-3}$ 
Table S5. Computational data for pyrroles and porphyrins.

\begin{tabular}{|c|c|c|c|c|c|c|c|c|c|c|}
\hline Species $^{[\mathrm{a}]}$ & File name ${ }^{[b]}$ & Stoichiometry ${ }^{[c]}$ & $\begin{array}{c}\text { SCF } E^{[\mathrm{d}]} \\
\text { a.u. }\end{array}$ & $\begin{array}{l}Z^{Z P V^{[e]}} \\
\text { a.u. }\end{array}$ & $\begin{array}{c}\text { lowest freq. } \\
\mathrm{cm}^{-1}\end{array}$ & $\begin{array}{l}\Delta G^{[\mathrm{g}]} \\
\text { a.u. }\end{array}$ & $\left\langle S^{2}\right\rangle^{[\mathrm{h}]}$ & $\begin{array}{c}\text { HOMO }^{[i]} \\
\text { eV }\end{array}$ & $\begin{array}{c}\text { LUMO }^{[i]} \\
\text { eV }\end{array}$ & $\begin{array}{c}\mathrm{HLG}^{[\mathrm{i}]} \\
\mathrm{eV}\end{array}$ \\
\hline 1 & pyrroles \1.pdb & $\mathrm{C}_{20} \mathrm{H}_{23} \mathrm{~N}_{3}$ & -940.2470689 & 0.392915 & 33.90 & -939.902252 & 0 & -5.29 & -1.48 & 3.81 \\
\hline 2 & pyrroles $\backslash 2 . p d b$ & $\mathrm{C}_{20} \mathrm{H}_{19} \mathrm{~N}_{3} \mathrm{O}_{2}$ & -1088.3372185 & 0.355340 & 30.37 & -1088.033416 & 0 & -5.46 & -1.77 & 3.70 \\
\hline $2(S 1)$ & pyrroles $\backslash 2 \_S 1 . p d b$ & $\mathrm{C}_{20} \mathrm{H}_{19} \mathrm{~N}_{3} \mathrm{O}_{2}$ & $\begin{array}{l}-1088.3224681 \\
(-1088.228846)\end{array}$ & [j] & [j] & [j] & 0 & -5.24 & -2.15 & 3.09 \\
\hline 3 & pyrroles\3.pdb & $\mathrm{C}_{18} \mathrm{H}_{13} \mathrm{NO}_{4}$ & -1049.4409582 & 0.274639 & 41.88 & -1049.213778 & 0 & -5.64 & -2.08 & 3.56 \\
\hline $3(\mathrm{~S} 1)$ & pyrroles \3_S1.pdb & $\mathrm{C}_{18} \mathrm{H}_{13} \mathrm{NO}_{4}$ & $\begin{array}{l}-1049.4291964 \\
(-1049.337049)\end{array}$ & [j] & [j] & [j] & 0 & -5.60 & -2.47 & 3.13 \\
\hline 4 & pyrroles $\backslash 4 . p d b$ & $\mathrm{C}_{28} \mathrm{H}_{24} \mathrm{~N}_{2} \mathrm{O}_{2}$ & -1341.4999314 & 0.454323 & 9.56 & -1341.103431 & 0 & -5.79 & -2.63 & 3.16 \\
\hline 5 & pyrroles \5.pdb & $\mathrm{C}_{16} \mathrm{H}_{7} \mathrm{NO}_{3}$ & -894.3999653 & 0.192108 & 67.52 & -894.247426 & 0 & -5.91 & -2.78 & 3.13 \\
\hline 6 & pyrroles \6.pdb & $\mathrm{C}_{22} \mathrm{H}_{11} \mathrm{~N}_{3} \mathrm{O}$ & -1084.5286011 & 0.276503 & 37.64 & -1084.295886 & 0 & -5.59 & -2.68 & 2.91 \\
\hline 7 & pyrroles $\backslash 7 . p d b$ & $\mathrm{C}_{26} \mathrm{H}_{13} \mathrm{~N}_{3} \mathrm{O}$ & -1238.1750984 & 0.323111 & 26.96 & -1237.899156 & 0 & -5.48 & -2.70 & 2.79 \\
\hline 8 & pyrroles \8.pdb & $\mathrm{C}_{26} \mathrm{H}_{13} \mathrm{BF}_{2} \mathrm{~N}_{2} \mathrm{O}_{2}$ & -1483.3594619 & 0.333446 & 16.83 & -1483.078479 & 0 & -5.74 & -2.81 & 2.94 \\
\hline 9 & pyrroles\9.pdb & $\mathrm{C}_{26} \mathrm{H}_{13} \mathrm{~N}_{3} \mathrm{O}$ & -1238.1599850 & 0.323047 & 30.97 & -1237.884084 & 0 & -5.16 & -2.61 & 2.55 \\
\hline$[\mathrm{k}]$ & pyrroles $\backslash H 2 . p d b$ & $\mathrm{C}_{14} \mathrm{H}_{9} \mathrm{~N}$ & -593.6832966 & 0.189418 & 116.62 & -593.528798 & 0 & -5.35 & -1.46 & 3.89 \\
\hline [l] & pyrroles\tBu2.pdb & $\mathrm{C}_{22} \mathrm{H}_{25} \mathrm{~N}$ & -908.2138391 & 0.413801 & 35.20 & -907.847994 & 0 & -5.29 & -1.32 & 3.97 \\
\hline [m] & pyrroles $\backslash \mathrm{Cl} 2 . p d b$ & $\mathrm{C}_{14} \mathrm{H}_{7} \mathrm{Cl}_{2} \mathrm{~N}$ & -1512.862041 & 0.169975 & 42.18 & -1512.731423 & 0 & -5.49 & -1.86 & 3.64 \\
\hline \multicolumn{11}{|c|}{$[10-\mathrm{Zn}]^{n}, n=$} \\
\hline 4 & 10-Zn\4.pdb & $\mathrm{C}_{108} \mathrm{H}_{84} \mathrm{~N}_{12} \mathrm{O}_{8} \mathrm{Zn}(4+)$ & -7203.0944843 & 1.679358 & 7.82 & -7201.576872 & 0.3219 & -12.05 & -11.88 & 0.16 \\
\hline 3 & $10-Z n \backslash 3 . p d b$ & $\mathrm{C}_{108} \mathrm{H}_{84} \mathrm{~N}_{12} \mathrm{O}_{8} \mathrm{Zn}(3+, 2)$ & -7203.5117882 & 1.679803 & 5.50 & -7201.994324 & 0.7667 & -10.90 & -10.43 & 0.46 \\
\hline 2 & $10-Z n \backslash 2 . p d b$ & $\mathrm{C}_{108} \mathrm{H}_{84} \mathrm{~N}_{12} \mathrm{O}_{8} \mathrm{Zn}(2+)$ & -7203.8727020 & 1.685432 & 7.34 & -7202.348331 & 0 & -9.24 & -8.30 & 0.94 \\
\hline 1 & 10-Zn\1.pdb & $\mathrm{C}_{108} \mathrm{H}_{84} \mathrm{~N}_{12} \mathrm{O}_{8} \mathrm{Zn}(1+, 2)$ & -7204.1578016 & 1.684698 & 6.30 & -7202.633507 & 0.7515 & -7.10 & -6.22 & 0.88 \\
\hline 0 & $10-Z n \backslash 0 . p d b$ & $\mathrm{C}_{108} \mathrm{H}_{84} \mathrm{~N}_{12} \mathrm{O}_{8} \mathrm{Zn}$ & -7204.3630053 & 1.685803 & 7.81 & -7202.835632 & 0 & -4.94 & -2.73 & 2.21 \\
\hline-1 & 10-Zn\-1.pdb & $\mathrm{C}_{108} \mathrm{H}_{84} \mathrm{~N}_{12} \mathrm{O}_{8} \mathrm{Zn}(1-, 2)$ & -7204.4382542 & 1.680595 & 3.66 & -7202.918866 & 0.7506 & -1.37 & -0.74 & 0.62 \\
\hline-2 & $10-Z n \backslash-2 . p d b$ & $\mathrm{C}_{108} \mathrm{H}_{84} \mathrm{~N}_{12} \mathrm{O}_{8} \mathrm{Zn}(2-)$ & -7204.4408552 & 1.677829 & 7.70 & -7202.922341 & 0.4212 & 0.57 & 1.34 & 0.77 \\
\hline-3 & 10-Zn\-3.pdb & $\mathrm{C}_{108} \mathrm{H}_{84} \mathrm{~N}_{12} \mathrm{O}_{8} \mathrm{Zn}(3-, 2)$ & -7204.3723564 & 1.673029 & 8.02 & -7202.859892 & 0.8647 & 2.44 & 3.16 & 0.73 \\
\hline-4 & $10-Z n \backslash-4 . p d b$ & $\mathrm{C}_{108} \mathrm{H}_{84} \mathrm{~N}_{12} \mathrm{O}_{8} \mathrm{Zn}(4-)$ & -7204.2364086 & 1.667595 & 8.20 & -7202.730526 & 1.6767 & 4.24 & 5.08 & 0.84 \\
\hline-5 & $10-Z n \backslash-5 \cdot p d b$ & $\mathrm{C}_{108} \mathrm{H}_{84} \mathrm{~N}_{12} \mathrm{O}_{8} \mathrm{Zn}(5-, 2)$ & -7204.0300431 & 1.661861 & 1.69 & -7202.533467 & 0.7507 & 6.11 & 6.60 & 0.49 \\
\hline-6 & 10-Zn\-6.pdb & $\mathrm{C}_{108} \mathrm{H}_{84} \mathrm{~N}_{12} \mathrm{O}_{8} \mathrm{Zn}(6-)$ & -7203.7676709 & 1.659318 & 8.33 & -7202.266692 & 0 & 7.69 & 8.71 & 1.01 \\
\hline-7 & 10-Zn\-7.pdb & $\mathrm{C}_{108} \mathrm{H}_{84} \mathrm{~N}_{12} \mathrm{O}_{8} \mathrm{Zn}(7-, 2)$ & -7203.4282697 & 1.653118 & 8.37 & -7201.931921 & 0.757 & 9.77 & 10.49 & 0.72 \\
\hline-8 & $10-Z n \backslash-8 . p d b$ & $\mathrm{C}_{108} \mathrm{H}_{84} \mathrm{~N}_{12} \mathrm{O}_{8} \mathrm{Zn}(8-)$ & -7203.0221612 & 1.647588 & 8.23 & -7201.530535 & 0 & 11.61 & 12.52 & 0.91 \\
\hline
\end{tabular}




\begin{tabular}{|c|c|c|c|c|c|c|c|c|c|c|}
\hline Species $^{[a]}$ & File name $^{[\mathrm{b}]}$ & Stoichiometry ${ }^{[c]}$ & $\begin{array}{c}\text { SCF } E^{[\mathrm{d}]} \\
\text { a.u. }\end{array}$ & $\begin{array}{l}\text { ZPV }^{[e]} \\
\text { a.u. }\end{array}$ & $\begin{array}{c}\text { lowest freq. } \\
\mathrm{cm}^{-1}\end{array}$ & $\begin{array}{l}\Delta G^{[\mathrm{g}]} \\
\text { a.u. }\end{array}$ & $\left\langle S^{2}\right\rangle^{[\mathrm{h}]}$ & $\begin{array}{c}\text { HOMO }^{[i]} \\
\text { eV }\end{array}$ & $\begin{array}{c}\text { LUMO }^{[i]} \\
\text { eV }\end{array}$ & $\begin{array}{c}\mathrm{HLG}^{[i]} \\
\mathrm{eV}\end{array}$ \\
\hline \multicolumn{11}{|c|}{$\left[11^{\prime}-\mathrm{Zn}\right]^{n}, n=$} \\
\hline 4 & $11^{\prime}-\mathrm{Zn} \backslash 4 . \mathrm{pdb}$ & $\mathrm{C}_{92} \mathrm{H}_{40} \mathrm{~N}_{8} \mathrm{O}_{8} \mathrm{Zn}(4+)$ & -6347.7836607 & 1.079378 & 8.11 & -6346.819097 & 0 & -14.35 & -13.64 & 0.71 \\
\hline 3 & $11^{\prime}-Z n \backslash 3 . p d b$ & $\mathrm{C}_{92} \mathrm{H}_{40} \mathrm{~N}_{8} \mathrm{O}_{8} \mathrm{Zn}(3+, 2)$ & -6348.2587669 & 1.080850 & 3.53 & -6347.293812 & 0.751 & -12.22 & -11.50 & 0.72 \\
\hline 2 & $11^{\prime}-Z n \backslash 2 . p d b$ & $\mathrm{C}_{92} \mathrm{H}_{40} \mathrm{~N}_{8} \mathrm{O}_{8} \mathrm{Zn}(2+)$ & -6348.6596326 & 1.084811 & 8.89 & -6347.689198 & 0 & -10.25 & -9.19 & 1.06 \\
\hline 1 & $11^{\prime}-\mathrm{Zn} \backslash 1 . \mathrm{pdb}$ & $\mathrm{C}_{92} \mathrm{H}_{40} \mathrm{~N}_{8} \mathrm{O}_{8} \mathrm{Zn}(1+, 2)$ & -6348.9767071 & 1.084316 & 8.98 & -6348.006322 & 0.7514 & -7.95 & -6.91 & 1.04 \\
\hline 0 & $11^{\prime}-Z n \backslash 0 . p d b$ & $\mathrm{C}_{92} \mathrm{H}_{40} \mathrm{~N}_{8} \mathrm{O}_{8} \mathrm{Zn}$ & -6349.2063590 & 1.085066 & 10.56 & -6348.233589 & 0 & -5.58 & -3.58 & 2.00 \\
\hline-1 & $11^{\prime}-\mathrm{Zn} \backslash-1 . p d b$ & $\mathrm{C}_{92} \mathrm{H}_{40} \mathrm{~N}_{8} \mathrm{O}_{8} \mathrm{Zn}(1-, 2)$ & -6349.3121769 & 1.081564 & 10.56 & -6348.343617 & 0.7504 & -2.18 & -1.68 & 0.49 \\
\hline-2 & $11^{\prime}-\mathrm{Zn \backslash -2.pdb}$ & $\mathrm{C}_{92} \mathrm{H}_{40} \mathrm{~N}_{8} \mathrm{O}_{8} \mathrm{Zn}(2-)$ & -6349.3483964 & 1.079728 & 10.45 & -6348.380802 & 0.3506 & -0.31 & 0.35 & 0.66 \\
\hline-3 & $11^{\prime}-Z n \backslash-3 \cdot p d b$ & $\mathrm{C}_{92} \mathrm{H}_{40} \mathrm{~N}_{8} \mathrm{O}_{8} \mathrm{Zn}(3-, 2)$ & -6349.3149116 & 1.076885 & 10.40 & -6348.350648 & 0.8608 & 1.57 & 2.24 & 0.67 \\
\hline-4 & $11^{\prime}-Z n \backslash-4 . p d b$ & $\mathrm{C}_{92} \mathrm{H}_{40} \mathrm{~N}_{8} \mathrm{O}_{8} \mathrm{Zn}(4-)$ & -6349.2109410 & 1.074057 & 10.51 & -6348.248770 & 2.4907 & 3.45 & 4.26 & 0.81 \\
\hline-5 & $11^{\prime}-Z n \backslash-5 \cdot p d b$ & $\mathrm{C}_{92} \mathrm{H}_{40} \mathrm{~N}_{8} \mathrm{O}_{8} \mathrm{Zn}(5-, 2)$ & -6349.0304367 & 1.070320 & 9.82 & -6348.072820 & 0.7519 & 5.50 & 5.93 & 0.43 \\
\hline-6 & $11^{\prime}-Z n \backslash-6 . p d b$ & $\mathrm{C}_{92} \mathrm{H}_{40} \mathrm{~N}_{8} \mathrm{O}_{8} \mathrm{Zn}(6-)$ & -6348.7883803 & 1.068802 & 9.77 & -6347.831203 & 0 & 7.26 & 8.24 & 0.99 \\
\hline-7 & $11^{\prime}-Z n \backslash-7 . p d b$ & $\mathrm{C}_{92} \mathrm{H}_{40} \mathrm{~N}_{8} \mathrm{O}_{8} \mathrm{Zn}(7-, 2)$ & -6348.4610836 & 1.064206 & 9.75 & -6347.509054 & 0.7529 & 9.57 & 10.25 & 0.68 \\
\hline-8 & $11^{\prime}-\mathrm{Zn} \backslash-8 . \mathrm{pdb}$ & $\mathrm{C}_{92} \mathrm{H}_{40} \mathrm{~N}_{8} \mathrm{O}_{8} \mathrm{Zn}(8-)$ & -6348.0602347 & 1.060740 & 10.11 & -6347.110725 & 0 & 11.57 & 12.66 & 1.09 \\
\hline
\end{tabular}

[a] SO state, if not indicated otherwise; B3LYP/6-31G(d,p) level of theory; PCM(DMSO) solvation for 1-9, otherwise no solvation model. [b] coordinate files provided as part of the SI. [c] $(n, m)$ corresponds respectively to the system charge and initial multiplicity. [d] Electronic energy. CIS (TDA) energies are given for $\mathrm{S} 1$ states in parentheses. [e] Zero-point vibrational energy. [f] Lowest vibrational frequency. [g] Gibbs free energy. [h] Expectation value of the total spin after annihilation of the first spin contaminant. [i] Frontier orbital energies and the HOMO-LUMO gap. [j] The frequency calculation was not performed. [k] Acenaphthopyrrole. [l] 2,5-Di-tert-butylacenaphthopyrrole. [m] 3,4-Dichloroacenaphthopyrrole. 
Table S6. Electronic transitions calculated for 1 using the TDA/PCM(DMSO)/B3LYP/6-31G(d,p) level of theory.

\begin{tabular}{|c|c|c|c|c|}
\hline No. & $\begin{array}{l}\text { Energy } \\
\left(\mathrm{cm}^{-1}\right)\end{array}$ & $\begin{array}{c}\lambda \\
(\mathrm{nm})\end{array}$ & $f^{[\mathrm{a}]}$ & $\begin{array}{c}\text { Major } \\
\text { excitations }^{[\mathrm{b}]}\end{array}$ \\
\hline 1 & 27855 & 359.0 & 0.002 & H-2»LUMO (98\%) \\
\hline 2 & 28494 & 350.9 & 0.003 & $\mathrm{H}-1 »$ LUMO (98\%) \\
\hline 3 & 28843 & 346.7 & 0.373 & $\begin{array}{l}\text { HOMO»LUMO } \\
(89 \%)\end{array}$ \\
\hline 4 & 31142 & 321.1 & 0.001 & H-3»LUMO (98\%) \\
\hline 5 & 33833 & 295.6 & 0.000 & $\begin{array}{l}\text { H-4»LUMO (39\%) } \\
\text { HOMO»L+1 (57\%) }\end{array}$ \\
\hline 6 & 38272 & 261.3 & 0.004 & $\mathrm{H}-1 » \mathrm{~L}+1$ (99\%) \\
\hline 7 & 38485 & 259.8 & 0.008 & H-5»LUMO (91\%) \\
\hline 8 & 39303 & 254.4 & 0.210 & $\mathrm{H}-2 » \mathrm{~L}+1$ (89\%) \\
\hline 9 & 40997 & 243.9 & 0.003 & $H-3 » L+1(97 \%)$ \\
\hline 10 & 41469 & 241.1 & 0.232 & $\begin{array}{l}\mathrm{H}-5 » \mathrm{~L}+1(14 \%) \\
\mathrm{H}-4 » \mathrm{~L} \mathrm{MO}(22 \%) \\
\text { HOMO»L+1 (10\%) } \\
\text { HOMO»L+2 (46\%) }\end{array}$ \\
\hline 11 & 41603 & 240.4 & 0.086 & $\begin{array}{l}\text { H-4»LUMO (16\%) } \\
\text { HOMO»L+1 (24\%) } \\
\text { HOMO»L+2 (40\%) }\end{array}$ \\
\hline 12 & 43442 & 230.2 & 0.001 & $H-1 » L+2(98 \%)$ \\
\hline 13 & 45760 & 218.5 & 0.196 & $\begin{array}{l}H-3 » L+2(53 \%) \\
H-2 » L+2(41 \%)\end{array}$ \\
\hline 14 & 46572 & 214.7 & 0.549 & $\begin{array}{l}\mathrm{H}-4 » \mathrm{~L}+1(10 \%) \\
\mathrm{H}-3 » \mathrm{~L}+2(41 \%) \\
\mathrm{H}-2 » \mathrm{~L}+2(35 \%)\end{array}$ \\
\hline 15 & 48277 & 207.1 & 0.503 & $\begin{array}{l}\text { H-6»LUMO (10\%) } \\
\mathrm{H}-5 » L+1(61 \%) \\
\mathrm{H}-4 » L U M O(11 \%)\end{array}$ \\
\hline 16 & 49562 & 201.8 & 0.112 & $\begin{array}{l}\text { H-8»LUMO (30\%) } \\
\text { H-6»LUMO (48\%) }\end{array}$ \\
\hline 17 & 49974 & 200.1 & 0.008 & H-7»LUMO (92\%) \\
\hline 18 & 50082 & 199.7 & 0.413 & $\begin{array}{l}H-4 » L+1(37 \%) \\
H-4 » L+2(30 \%) \\
H-2 » L+2(11 \%)\end{array}$ \\
\hline 19 & 50764 & 197.0 & 0.003 & $\begin{array}{l}\text { H-8»LUMO (64\%) } \\
\text { H-6»LUMO (24\%) }\end{array}$ \\
\hline 20 & 51432 & 194.4 & 0.095 & $\begin{array}{l}\mathrm{H}-5 » \mathrm{~L}+2(64 \%) \\
\mathrm{HOMO} \text { ( }+4(25 \%)\end{array}$ \\
\hline 21 & 52289 & 191.2 & 0.033 & $\begin{array}{l}\mathrm{H}-9 » \mathrm{LUMO}(13 \%) \\
\mathrm{H}-4 » \mathrm{~L}+1(18 \%) \\
\mathrm{H}-2 » \mathrm{~L}+4(17 \%) \\
\mathrm{HOMO}(\mathrm{L}+3(43 \%)\end{array}$ \\
\hline 22 & 52835 & 189.3 & 0.982 & $\begin{array}{l}\mathrm{H}-9 » \mathrm{LUMO}(10 \%) \\
\mathrm{H}-4 » \mathrm{~L}+1(16 \%) \\
\mathrm{H}-4 » \mathrm{~L}+2(48 \%) \\
\text { HOMO»L+3 (13\%) }\end{array}$ \\
\hline 23 & 54240 & 184.4 & 0.000 & $\begin{array}{l}H-1 » L+3(82 \%) \\
H-1 » L+5(14 \%)\end{array}$ \\
\hline 24 & 55182 & 181.2 & 0.006 & H-11»LUMO (95\%) \\
\hline 25 & 55757 & 179.4 & 0.274 & $\begin{array}{l}H-5 » L+2(15 \%) \\
H O M O » L+4(58 \%)\end{array}$ \\
\hline 26 & 55807 & 179.2 & 0.001 & $\begin{array}{l}\text { H-9»LUMO (12\%) } \\
\text { HOMO»L+5 (38\%) } \\
\text { HOMO»L+6 (33\%) }\end{array}$ \\
\hline 27 & 55879 & 179.0 & 0.008 & $\begin{array}{l}H-3 » L+3(20 \%) \\
H-2 » L+3(18 \%) \\
H-1 » L+4(53 \%)\end{array}$ \\
\hline 28 & 56232 & 177.8 & 0.080 & $\begin{array}{l}\text { H-9»LUMO (33\%) } \\
\text { H-6»L+1 (16\%) } \\
\text { HOMO»L+6 (27\%) }\end{array}$ \\
\hline
\end{tabular}

\begin{tabular}{|c|c|c|c|c|}
\hline No. & $\begin{array}{l}\text { Energy } \\
\left(\mathrm{cm}^{-1}\right)\end{array}$ & $\begin{array}{c}\lambda \\
(\mathrm{nm})\end{array}$ & $f^{[\mathrm{a}]}$ & $\begin{array}{c}\text { Major } \\
\text { excitations }^{[\mathrm{b}]}\end{array}$ \\
\hline \multirow[t]{3}{*}{29} & 56555 & 176.8 & 0.120 & H-10»LUMO (34\%) \\
\hline & & & & $H-2 » L+3(28 \%)$ \\
\hline & & & & $H-1 » L+4(25 \%)$ \\
\hline \multirow[t]{4}{*}{30} & 56634 & 176.6 & 0.064 & $\mathrm{H}-2 » \mathrm{~L}+4(11 \%)$ \\
\hline & & & & $H-1 » L+5(11 \%)$ \\
\hline & & & & HOMO»L+5 (33\%) \\
\hline & & & & HOMO»L+6 (29\%) \\
\hline \multirow[t]{2}{*}{31} & 56741 & 176.2 & 0.012 & $H-1 » L+3(11 \%)$ \\
\hline & & & & $H-1 » L+5(70 \%)$ \\
\hline \multirow[t]{3}{*}{32} & 56832 & 176.0 & 0.003 & $\mathrm{H}-10 » \mathrm{LUMO}(51 \%)$ \\
\hline & & & & $H-3 » L+3(10 \%)$ \\
\hline & & & & $H-1 » L+4(15 \%)$ \\
\hline \multirow[t]{2}{*}{33} & 57615 & 173.6 & 0.101 & $\mathrm{H}-3 » \mathrm{~L}+3(44 \%)$ \\
\hline & & & & $H-2 » L+3(19 \%)$ \\
\hline \multirow[t]{3}{*}{34} & 58265 & 171.6 & 0.028 & $H-6 » L+2(13 \%)$ \\
\hline & & & & $H-3 » L+4(19 \%)$ \\
\hline & & & & $H-2 » L+4(35 \%)$ \\
\hline \multirow[t]{4}{*}{35} & 58981 & 169.5 & 0.003 & $H-7 » L+1(17 \%)$ \\
\hline & & & & $H-3 » L+3(16 \%)$ \\
\hline & & & & $H-3 » L+5(38 \%)$ \\
\hline & & & & $H-2 » L+5$ (19\%) \\
\hline \multirow[t]{2}{*}{36} & 59055 & 169.3 & 0.028 & $\mathrm{H}-7 » \mathrm{~L}+1$ (72\%) \\
\hline & & & & $H-3 » L+5(12 \%)$ \\
\hline \multirow[t]{3}{*}{37} & 59101 & 169.2 & 0.004 & $H-8 » L+1(31 \%)$ \\
\hline & & & & $H-6 » L+1(16 \%)$ \\
\hline & & & & $H-3 » L+4(16 \%)$ \\
\hline \multirow[t]{2}{*}{38} & 59154 & 169.1 & 0.021 & $H-8 » L+1(15 \%)$ \\
\hline & & & & $H-3 » L+4(60 \%)$ \\
\hline \multirow[t]{2}{*}{39} & 59648 & 167.7 & 0.004 & $H-2 » L+5(11 \%)$ \\
\hline & & & & $\mathrm{H}-2 » \mathrm{~L}+6(72 \%)$ \\
\hline \multirow[t]{3}{*}{40} & 60014 & 166.6 & 0.001 & $\mathrm{H}-8 » \mathrm{~L}+1$ (44\%) \\
\hline & & & & $H-6 » L+1$ (18\%) \\
\hline & & & & $H-4 » L+4(12 \%)$ \\
\hline 41 & 60198 & 166.1 & 0.003 & HOMO»L+8 (84\%) \\
\hline \multirow[t]{3}{*}{42} & 60596 & 165.0 & 0.001 & $H-3 » L+5(11 \%)$ \\
\hline & & & & $\mathrm{H}-2 » \mathrm{~L}+5$ (48\%) \\
\hline & & & & $H-2 » L+6$ (19\%) \\
\hline \multirow[t]{2}{*}{43} & 60874 & 164.3 & 0.006 & H-16»LUMO (12\%) \\
\hline & & & & $\mathrm{H}-12 » \mathrm{LUMO}(70 \%)$ \\
\hline \multirow[t]{2}{*}{44} & 61189 & 163.4 & 0.001 & $H-2 » L+5(10 \%)$ \\
\hline & & & & HOMO»L+7 (71\%) \\
\hline 45 & 61457 & 162.7 & 0.006 & $\mathrm{H}-13 »$ LUMO (80\%) \\
\hline 46 & 61820 & 161.8 & 0.012 & $\mathrm{H}-14 » \mathrm{LUMO}(71 \%)$ \\
\hline \multirow[t]{2}{*}{47} & 62281 & 160.6 & 0.010 & H-16»LUMO (71\%) \\
\hline & & & & $\mathrm{H}-12 »$ LUMO (10\%) \\
\hline \multirow[t]{3}{*}{48} & 62362 & 160.4 & 0.005 & $H-9 » L+1(21 \%)$ \\
\hline & & & & $H-4 » L+3(41 \%)$ \\
\hline & & & & $H-1 » L+7(25 \%)$ \\
\hline 49 & 62508 & 160.0 & 0.000 & $\mathrm{H}-15 »$ LUMO (82\%) \\
\hline \multirow[t]{2}{*}{50} & 62646 & 159.6 & 0.146 & $H-4 » L+3(14 \%)$ \\
\hline & & & & $\mathrm{H}-1 » \mathrm{~L}+7$ (54\%) \\
\hline
\end{tabular}

[a] Oscillator strength. [b] Contributions smaller than $10 \%$ are not included. $\mathrm{H}=\mathrm{HOMO}, \mathrm{L}=\mathrm{LUMO}$. Orbitals are numbered consecutively regardless of possible degeneracies. 
Table S7. Electronic transitions calculated for 2 using the TDA/PCM(DMSO)/B3LYP/6-31G(d,p) level of theory.

\begin{tabular}{|c|c|c|c|c|c|c|c|c|c|}
\hline No. & $\begin{array}{l}\text { Energy } \\
\left(\mathrm{cm}^{-1}\right)\end{array}$ & $\begin{array}{c}\lambda \\
(\mathrm{nm})\end{array}$ & $f^{[\mathrm{a}]}$ & $\begin{array}{c}\text { Major } \\
\text { excitations }^{[\mathrm{b}]}\end{array}$ & No. & $\begin{array}{l}\text { Energy } \\
\left(\mathrm{cm}^{-1}\right)\end{array}$ & $\begin{array}{c}\lambda \\
(\mathrm{nm})\end{array}$ & $f^{[\mathrm{a}]}$ & $\begin{array}{c}\text { Major } \\
\text { excitations }^{[\mathrm{b}]}\end{array}$ \\
\hline 1 & 26811 & 373.0 & 0.004 & H-1»LUMO (98\%) & \multirow[t]{4}{*}{25} & \multirow[t]{4}{*}{48451} & \multirow[t]{4}{*}{206.4} & \multirow[t]{4}{*}{0.006} & $H-7 » L+1(18 \%)$ \\
\hline 2 & 27862 & 358.9 & 0.387 & HOMO»LUMO & & & & & $H-7 » L+2(11 \%)$ \\
\hline & & & & (91\%) & & & & & $H-5 » L+2(31 \%)$ \\
\hline 3 & 32647 & 306.3 & 0.002 & H-2»LUMO (99\%) & & & & & $H-3 » L+2(14 \%)$ \\
\hline \multirow[t]{3}{*}{4} & \multirow[t]{3}{*}{33224} & \multirow[t]{3}{*}{301.0} & \multirow[t]{3}{*}{0.003} & H-5»LUMO (37\%) & \multirow[t]{2}{*}{26} & \multirow[t]{2}{*}{49712} & \multirow[t]{2}{*}{201.2} & \multirow[t]{2}{*}{0.010} & H-9»LUMO (50\%) \\
\hline & & & & H-3»LUMO (19\%) & & & & & H-8»LUMO (40\%) \\
\hline & & & & HOMO»L+1 (39\%) & \multirow[t]{2}{*}{27} & \multirow[t]{2}{*}{50237} & \multirow[t]{2}{*}{199.1} & \multirow[t]{2}{*}{0.397} & $H-7 » L+2(20 \%)$ \\
\hline 5 & 33758 & 296.2 & 0.003 & H-3»LUMO (78\%) & & & & & $H-1 » L+4(54 \%)$ \\
\hline & & & & HOMO»L+1 (11\%) & 28 & 50748 & 197.1 & 0.056 & H-9»LUMO (33\%) \\
\hline 6 & 34718 & 288.0 & 0.011 & H-6»LUMO (21\%) & & & & & H-8»LUMO (19\%) \\
\hline & & & & $\mathrm{H}-4 » \mathrm{LUMO}(76 \%)$ & & & & & $H-6 » L+2(29 \%)$ \\
\hline 7 & 36643 & 272.9 & 0.037 & H-7»LUMO (64\%) & 29 & 51237 & 195.2 & 0.282 & $H-6 » L+3(12 \%)$ \\
\hline & & & & H-5»LUMO (21\%) & & & & & $H-5 » L+2(18 \%)$ \\
\hline & & & & HOMO»L+1 (10\%) & & & & & $H-4 » L+3(10 \%)$ \\
\hline 8 & 38211 & 261.7 & 0.008 & H-6»LUMO (67\%) & & & & & $H-2 » L+3(16 \%)$ \\
\hline & & & & H-4»LUMO (19\%) & & & & & HOMO»L+5 (15\%) \\
\hline 9 & 38622 & 258.9 & 0.011 & HOMO»L+1 (14\%) & 30 & 51324 & 194.8 & 0.008 & H-9»LUMO (11\%) \\
\hline & & & & HOMO»L+2 (74\%) & & & & & H-8»LUMO (15\%) \\
\hline 10 & 38776 & 257.9 & 0.204 & $\mathrm{H}-1 » \mathrm{~L}+1$ (79\%) & & & & & $H-6 » L+2(16 \%)$ \\
\hline 11 & 41093 & 243.4 & 0.258 & H-7»LUMO (21\%) & & & & & $H-3 » L+3(23 \%)$ \\
\hline & & & & H-5»LUMO (18\%) & 31 & 51559 & 194.0 & 0.218 & $H-6 » L+2(20 \%)$ \\
\hline & & & & $H-4 » L+1$ (15\%) & & & & & $H-4 » L+2(17 \%)$ \\
\hline & & & & $\begin{array}{l}\text { HOMO»L+1 (18\%) } \\
\text { HOMO»L+2 (12\%) }\end{array}$ & & & & & $H-1 » L+5(10 \%)$ \\
\hline & & & & & 32 & 52477 & 190.6 & 0.468 & $\mathrm{H}-11 » \mathrm{LUMO}(22 \%)$ \\
\hline 12 & 42356 & 236.1 & 0.341 & $\mathrm{H}-1 » \mathrm{~L}+2$ (54\%) & & & & & H-10»LUMO (17\%) \\
\hline & & & & HOMO»L+3 (13\%) & & & & & $\mathrm{H}-7 » \mathrm{~L}+2(24 \%)$ \\
\hline 13 & 42583 & 234.8 & 0.007 & $H-2 » L+1(93 \%)$ & 33 & 53014 & 188.6 & 0.276 & $\mathrm{H}-11 »$ LUMO (60\%) \\
\hline 14 & 43590 & 229.4 & 0.108 & $\mathrm{H}-3 » \mathrm{~L}+1$ (88\%) & & & & & $H-7 » L+2(14 \%)$ \\
\hline 15 & 44112 & 226.7 & 0.024 & $H-6 » L+1(15 \%)$ & 34 & 53152 & 188.1 & 0.024 & $\mathrm{H}-3 » \mathrm{~L}+4(29 \%)$ \\
\hline & & & & $H-4 » L+1(38 \%)$ & & & & & $H-2 » L+3(20 \%)$ \\
\hline 16 & 44970 & 222.4 & 0.204 & $\mathrm{H}-1 » \mathrm{~L}+2$ (16\%) & & & & & HOMO»L+5 (16\%) \\
\hline & & & & HOMO»L+3 (71\%) & 35 & 53292 & 187.6 & 0.027 & $H-3 » L+3(16 \%)$ \\
\hline 17 & 45890 & 217.9 & 0.067 & $\mathrm{H}-4 » \mathrm{~L}+1$ (28\%) & & & & & $H-2 » L+4(74 \%)$ \\
\hline & & & & $\begin{array}{l}H-4 » L+2(10 \%) \\
H-2 » L+2(20 \%)\end{array}$ & 36 & 53688 & 186.3 & 0.002 & $\mathrm{H}-10 » \mathrm{LUMO}(14 \%)$ \\
\hline 10 & 45051 & 2176 & 0157 & & & & & & $\mathrm{H}-3 » \mathrm{~L}+4(21 \%)$ \\
\hline 18 & 45951 & 217.6 & 0.157 & $H-3 » L+2(47 \%)$ & & & & & $H-2 » L+3(13 \%)$ \\
\hline 19 & 46122 & 216.8 & 0.052 & $\begin{array}{l}H-2 » L+2(26 \%) \\
H O M » l+4(49 \%)\end{array}$ & 37 & 55052 & 181.6 & 0.010 & $H-5 » L+3(63 \%)$ \\
\hline & & & & HOIVIU »L+4 (49\%) & & & & & $H-4 » L+4(22 \%)$ \\
\hline 20 & 46599 & 214.6 & 0.022 & $H-4 » L+2(21 \%)$ & 38 & 55167 & 181.3 & 0.031 & $\mathrm{H}-5 » \mathrm{~L}+4(36 \%)$ \\
\hline & & & & $\mathrm{H}-2 » \mathrm{~L}+2$ (42\%) & & & & & $H-4 » L+3(37 \%)$ \\
\hline 21 & 47462 & 210.7 & 0.078 & $\mathrm{H}-7 » \mathrm{~L}+1$ (39\%) & 39 & 55835 & 179.1 & 0.036 & $\mathrm{H}-13 »$ LUMO (19\%) \\
\hline & & & & $\mathrm{H}-5 » \mathrm{~L}+1(28 \%)$ & & & & & $\mathrm{H}-10 »$ LUMO (18\%) \\
\hline & & & & $H-3 » L+2(19 \%)$ & & & & & $H-5 » L+4(20 \%)$ \\
\hline 22 & 47495 & 210.5 & 0.130 & $H-6 » L+1(38 \%)$ & & & & & HOMO»L+5 (15\%) \\
\hline & & & & $H-1 » L+3(29 \%)$ & 40 & 56192 & 178.0 & 0.113 & $\mathrm{H}-4 » \mathrm{~L}+4(45 \%)$ \\
\hline & & & & HOMO»L+4 (13\%) & & & & & HOMO»L+6 (23\%) \\
\hline 23 & 48018 & 208.3 & 0.000 & $H-7 » L+1(10 \%)$ & 41 & 56484 & 177.0 & 0.000 & $\mathrm{H}-13 » \mathrm{LUMO}(70 \%)$ \\
\hline & & & & $\mathrm{H}-5 » \mathrm{~L}+1(19 \%)$ & & & & & $\mathrm{H}-5 » \mathrm{~L}+4(11 \%)$ \\
\hline & & & & $\begin{array}{l}H-5 » L+2(18 \%) \\
H-3 » L+2(11 \%)\end{array}$ & 42 & 56751 & 176.2 & 0.036 & H-10»LUMO (14\%) \\
\hline & & & & $H-1 » L+4(15 \%)$ & & & & & $\mathrm{H}-5 » \mathrm{~L}+4(22 \%)$ \\
\hline & & & & & & & & & $H-4 » L+3(10 \%)$ \\
\hline 24 & 48417 & 206.5 & 0.203 & $H-6 » L+1(11 \%)$ & & & & & $H-3 » L+4(10 \%)$ \\
\hline & & & & $H-4 » L+2(30 \%)$ & & & & & HOMO»L+5 (13\%) \\
\hline & & & & $H-1 » L+3(36 \%)$ & 12 & 56762 & $176 ?$ & & \\
\hline & & & & & 43 & 56763 & 176.2 & 0.076 & $\begin{array}{l}H-7 » L+3(22 \%) \\
H-6 » L+4(29 \%)\end{array}$ \\
\hline & & & & & & & & & HOMO»L+6 (23\%) \\
\hline
\end{tabular}




\begin{tabular}{|c|c|c|c|c|}
\hline No. & $\begin{array}{l}\text { Energy } \\
\left(\mathrm{cm}^{-1}\right)\end{array}$ & $\begin{array}{c}\lambda \\
(\mathrm{nm})\end{array}$ & $f^{[\mathrm{a}]}$ & $\begin{array}{c}\text { Major } \\
\text { excitations }^{[\mathrm{b}]}\end{array}$ \\
\hline 44 & 57033 & 175.3 & 0.001 & $\begin{array}{l}\text { HOMO»L+7 (48\%) } \\
\text { HOMO»L+8 (48\%) }\end{array}$ \\
\hline 45 & 57284 & 174.6 & 0.120 & $\begin{array}{l}H-12 » L U M O(19 \%) \\
H-1 » L+5(47 \%)\end{array}$ \\
\hline 46 & 57295 & 174.5 & 0.001 & $\begin{array}{l}H-7 » L+4(15 \%) \\
H-6 » L+3(54 \%)\end{array}$ \\
\hline 47 & 58404 & 171.2 & 0.200 & $\begin{array}{l}\mathrm{H}-12 » \mathrm{LUMO}(52 \%) \\
\mathrm{H}-1 » \mathrm{~L}+5(14 \%)\end{array}$ \\
\hline 48 & 58763 & 170.2 & 0.175 & $\begin{array}{l}\mathrm{H}-6 » \mathrm{~L}+4(33 \%) \\
\mathrm{HOMO} \text { (L+6 (30\%) }\end{array}$ \\
\hline 49 & 59203 & 168.9 & 0.105 & $\begin{array}{l}H-7 » L+4(43 \%) \\
H-1 » L+6(29 \%)\end{array}$ \\
\hline
\end{tabular}

\begin{tabular}{ccccc}
\hline No. & $\begin{array}{c}\text { Energy } \\
\left(\mathbf{c m}^{-1}\right)\end{array}$ & $\begin{array}{c}\boldsymbol{\lambda} \\
(\mathbf{n m})\end{array}$ & $\boldsymbol{f}^{[\mathrm{a}]}$ & $\begin{array}{c}\text { Major } \\
\text { excitations }^{[\mathrm{b}]}\end{array}$ \\
\hline 50 & 59413 & 168.3 & 0.251 & $\mathrm{H}-12 » \mathrm{LUMO}(20 \%)$ \\
& & & & $\mathrm{H}-7 » \mathrm{H}+3(27 \%)$ \\
& & & & $\mathrm{H}-3 » \mathrm{H}+3(16 \%)$ \\
& & & & $\mathrm{H}-2 » \mathrm{~L}+4(11 \%)$ \\
\hline
\end{tabular}

[a] Oscillator strength. [b] Contributions smaller than $10 \%$ are not included. $\mathrm{H}=\mathrm{HOMO}, \mathrm{L}=$ LUMO. Orbitals are numbered consecutively regardless of possible degeneracies. 
Table S8. Electronic transitions calculated for 3 using the TDA/PCM(DMSO)/B3LYP/6-31G(d,p) level of theory.

\begin{tabular}{|c|c|c|c|c|}
\hline No. & $\begin{array}{l}\text { Energy } \\
\left(\mathrm{cm}^{-1}\right)\end{array}$ & $\begin{array}{c}\lambda \\
(\mathrm{nm})\end{array}$ & $f^{[\mathrm{a}]}$ & $\begin{array}{c}\text { Major } \\
\text { excitations }^{[\mathrm{b}]}\end{array}$ \\
\hline 1 & 25444 & 393.0 & 0.003 & H-1»LUMO (98\%) \\
\hline 2 & 26708 & 374.4 & 0.354 & $\begin{array}{l}\text { HOMO»LUMO } \\
(89 \%)\end{array}$ \\
\hline \multirow[t]{3}{*}{3} & 32817 & 304.7 & 0.003 & H-2»LUMO (40\%) \\
\hline & & & & HOMO»L+1 (44\%) \\
\hline & & & & HOMO»L+2 (13\%) \\
\hline \multirow[t]{3}{*}{4} & 35272 & 283.5 & 0.052 & H-2»LUMO (16\%) \\
\hline & & & & HOMO»L+1 (48\%) \\
\hline & & & & HOMO»L+2 (31\%) \\
\hline \multirow[t]{2}{*}{5} & 36473 & 274.2 & 0.027 & H-3»LUMO (75\%) \\
\hline & & & & $H-1 » L+1(10 \%)$ \\
\hline 6 & 36850 & 271.4 & 0.055 & H-4»LUMO (84\%) \\
\hline \multirow[t]{2}{*}{7} & 37812 & 264.5 & 0.035 & H-5»LUMO (71\%) \\
\hline & & & & HOMO»L+2 (15\%) \\
\hline \multirow[t]{3}{*}{8} & 38422 & 260.3 & 0.584 & H-3»LUMO (10\%) \\
\hline & & & & $H-1 » L+1(57 \%)$ \\
\hline & & & & $\mathrm{H}-1 » \mathrm{~L}+2(17 \%)$ \\
\hline \multirow[t]{4}{*}{9} & 40388 & 247.6 & 0.242 & H-5»LUMO (17\%) \\
\hline & & & & $H-3 » L+2(10 \%)$ \\
\hline & & & & H-2»LUMO (21\%) \\
\hline & & & & HOMO»L+2 (35\%) \\
\hline \multirow[t]{3}{*}{10} & 40455 & 247.2 & 0.334 & $H-2 » L+1(10 \%)$ \\
\hline & & & & $\mathrm{H}-1 » \mathrm{~L}+1$ (13\%) \\
\hline & & & & $H-1 » L+2$ (69\%) \\
\hline \multirow[t]{2}{*}{11} & 43728 & 228.7 & 0.028 & H-6»LUMO (68\%) \\
\hline & & & & $\mathrm{H}-4 » \mathrm{~L}+1(18 \%)$ \\
\hline \multirow[t]{2}{*}{12} & 44391 & 225.3 & 0.053 & $\mathrm{H}-4 » \mathrm{~L}+1(42 \%)$ \\
\hline & & & & $H-3 » L+1(43 \%)$ \\
\hline \multirow[t]{2}{*}{13} & 44541 & 224.5 & 0.016 & $H-2 » L+1(62 \%)$ \\
\hline & & & & HOMO»L+4 (10\%) \\
\hline \multirow[t]{3}{*}{14} & 44716 & 223.6 & 0.085 & H-6»LUMO (23\%) \\
\hline & & & & $H-4 » L+1(20 \%)$ \\
\hline & & & & $\mathrm{H}-3 » \mathrm{~L}+1$ (44\%) \\
\hline \multirow[t]{2}{*}{15} & 45684 & 218.9 & 0.015 & $H-5 » L+1(68 \%)$ \\
\hline & & & & HOMO»L+4 (13\%) \\
\hline 16 & 46117 & 216.8 & 0.001 & H-7»LUMO (95\%) \\
\hline \multirow[t]{3}{*}{17} & 46594 & 214.6 & 0.060 & H-8»LUMO (22\%) \\
\hline & & & & $H-3 » L+2(12 \%)$ \\
\hline & & & & HOMO»L+3 (52\%) \\
\hline \multirow[t]{2}{*}{18} & 46826 & 213.6 & 0.000 & $\mathrm{H}-2 » \mathrm{~L}+1(11 \%)$ \\
\hline & & & & HOMO»L+4 (61\%) \\
\hline \multirow[t]{3}{*}{19} & 48662 & 205.5 & 0.003 & $H-3 » L+2(21 \%)$ \\
\hline & & & & $\mathrm{H}-1 » \mathrm{~L}+4(49 \%)$ \\
\hline & & & & HOMO»L+3 (22\%) \\
\hline \multirow[t]{3}{*}{20} & 48867 & 204.6 & 0.009 & $\mathrm{H}-10 »$ LUMO (31\%) \\
\hline & & & & H-8»LUMO (35\%) \\
\hline & & & & $H-1 » L+4(18 \%)$ \\
\hline 21 & 49809 & 200.8 & 0.010 & $\mathrm{H}-10 »$ LUMO (64\%) \\
\hline & & & & H-8»LUMO (14\%) \\
\hline 22 & 50364 & 198.6 & 0.002 & H-8»LUMO (10\%) \\
\hline & & & & $\mathrm{H}-4 » \mathrm{~L}+2(76 \%)$ \\
\hline 23 & 50664 & 197.4 & 0.020 & $\mathrm{H}-2 » \mathrm{~L}+2(12 \%)$ \\
\hline & & & & $H-1 » L+3(46 \%)$ \\
\hline & & & & HOMO»L+5 (10\%) \\
\hline 24 & 51369 & 194.7 & 0.766 & $\mathrm{H}-11 » L U M O(16 \%)$ \\
\hline & & & & $H-5 » L+2(13 \%)$ \\
\hline & & & & $\mathrm{H}-2 » \mathrm{~L}+2(20 \%)$ \\
\hline & & & & $\mathrm{H}-1 » \mathrm{~L}+3(27 \%)$ \\
\hline 25 & 51602 & 193.8 & 0.077 & $\mathrm{H}-11 »$ LUMO (36\%) \\
\hline & & & & H-9»LUMO (22\%) \\
\hline & & & & $H-5 » L+2(32 \%)$ \\
\hline
\end{tabular}

\begin{tabular}{|c|c|c|c|c|}
\hline No. & $\begin{array}{l}\text { Energy } \\
\left(\mathrm{cm}^{-1}\right)\end{array}$ & $\begin{array}{c}\lambda \\
(\mathrm{nm})\end{array}$ & $f^{[a]}$ & $\begin{array}{c}\text { Major } \\
\text { excitations }^{[\mathrm{b}]}\end{array}$ \\
\hline \multirow[t]{2}{*}{26} & 51674 & 193.5 & 0.511 & $H-3 » L+2(42 \%)$ \\
\hline & & & & $\mathrm{H}-1 » \mathrm{~L}+4(18 \%)$ \\
\hline \multirow[t]{4}{*}{27} & 52316 & 191.1 & 0.375 & $\mathrm{H}-11 » \mathrm{LUMO}(34 \%)$ \\
\hline & & & & H-9»LUMO (10\%) \\
\hline & & & & $H-5 » L+2(20 \%)$ \\
\hline & & & & $H-2 » L+2(18 \%)$ \\
\hline \multirow[t]{4}{*}{28} & 53342 & 187.5 & 0.276 & $\mathrm{H}-12 » L U M O(15 \%)$ \\
\hline & & & & H-9»LUMO (25\%) \\
\hline & & & & $\mathrm{H}-5 » \mathrm{~L}+2(14 \%)$ \\
\hline & & & & $H-2 » L+2(19 \%)$ \\
\hline 29 & 53894 & 185.5 & 0.000 & $H-6 » L+1(80 \%)$ \\
\hline \multirow[t]{2}{*}{30} & 54839 & 182.4 & 0.003 & $\mathrm{H}-12 »$ LUMO (53\%) \\
\hline & & & & HOMO»L+5 (13\%) \\
\hline \multirow[t]{2}{*}{31} & 55660 & 179.7 & 0.083 & $H-7 » L+1(60 \%)$ \\
\hline & & & & $H-2 » L+4(17 \%)$ \\
\hline 32 & 55845 & 179.1 & 0.041 & $\mathrm{H}-2 » \mathrm{~L}+3(84 \%)$ \\
\hline \multirow[t]{3}{*}{33} & 55985 & 178.6 & 0.007 & $\mathrm{H}-13 »$ LUMO (13\%) \\
\hline & & & & $\mathrm{H}-7 » \mathrm{~L}+1$ (18\%) \\
\hline & & & & $H-2 » L+4(49 \%)$ \\
\hline \multirow[t]{2}{*}{34} & 56366 & 177.4 & 0.004 & $\mathrm{H}-13 »$ LUMO (75\%) \\
\hline & & & & $H-7 » L+1(15 \%)$ \\
\hline \multirow[t]{2}{*}{35} & 56383 & 177.4 & 0.143 & $H-3 » L+4(13 \%)$ \\
\hline & & & & HOMO»L+5 (37\%) \\
\hline \multirow[t]{3}{*}{36} & 56487 & 177.0 & 0.006 & $H-6 » L+2(16 \%)$ \\
\hline & & & & $\mathrm{H}-4 » \mathrm{~L}+4(41 \%)$ \\
\hline & & & & $H-3 » L+4(21 \%)$ \\
\hline \multirow[t]{2}{*}{37} & 56679 & 176.4 & 0.001 & $H-3 » L+3(67 \%)$ \\
\hline & & & & HOMO»L+6 (18\%) \\
\hline \multirow[t]{2}{*}{38} & 56714 & 176.3 & 0.006 & $H-6 » L+2(72 \%)$ \\
\hline & & & & $H-3 » L+4(10 \%)$ \\
\hline \multirow[t]{3}{*}{39} & 57824 & 172.9 & 0.007 & $H-5 » L+4(27 \%)$ \\
\hline & & & & $H-4 » L+3(23 \%)$ \\
\hline & & & & $H-2 » L+4(14 \%)$ \\
\hline 40 & 57947 & 172.6 & 0.000 & HOMO»L+7 (91\%) \\
\hline \multirow[t]{2}{*}{41} & 58136 & 172.0 & 0.004 & $\mathrm{H}-14 »$ LUMO (48\%) \\
\hline & & & & $H-3 » L+4(16 \%)$ \\
\hline \multirow[t]{3}{*}{42} & 58333 & 171.4 & 0.001 & $\mathrm{H}-14 » \mathrm{LUMO}(32 \%)$ \\
\hline & & & & $H-4 » L+4(15 \%)$ \\
\hline & & & & $H-3 » L+4(11 \%)$ \\
\hline \multirow[t]{2}{*}{43} & 58740 & 170.2 & 0.020 & $H-8 » L+1(49 \%)$ \\
\hline & & & & $H-1 » L+6(23 \%)$ \\
\hline \multirow[t]{2}{*}{44} & 58843 & 169.9 & 0.014 & $H-7 » L+2(63 \%)$ \\
\hline & & & & $H-1 » L+5(23 \%)$ \\
\hline \multirow[t]{3}{*}{45} & 59006 & 169.5 & 0.132 & $H-9 » L+1(11 \%)$ \\
\hline & & & & $H-7 » L+2(30 \%)$ \\
\hline & & & & $H-1 » L+5(50 \%)$ \\
\hline \multirow[t]{2}{*}{46} & 59417 & 168.3 & 0.161 & $H-3 » L+3(16 \%)$ \\
\hline & & & & HOMO»L+6 (55\%) \\
\hline 47 & 59530 & 168.0 & 0.025 & $H-10 » L+1(85 \%)$ \\
\hline 48 & 59610 & 167.8 & 0.044 & H-16»LUMO (76\%) \\
\hline \multirow[t]{2}{*}{49} & 60693 & 164.8 & 0.048 & $H-5 » L+4(36 \%)$ \\
\hline & & & & $H-4 » L+3(56 \%)$ \\
\hline 50 & 60958 & 164.0 & 0.063 & $\mathrm{H}-15 »$ LUMO (78\%) \\
\hline
\end{tabular}

[a] Oscillator strength. [b] Contributions smaller than $10 \%$ are not included. $\mathrm{H}=\mathrm{HOMO}, \mathrm{L}=\mathrm{LUMO}$. Orbitals are numbered consecutively regardless of possible degeneracies. 
Table S9. Electronic transitions calculated for 4 using the TDA/PCM(DMSO)/B3LYP/6-31G(d,p) level of theory.

\begin{tabular}{|c|c|c|c|c|}
\hline No. & $\begin{array}{l}\text { Energy } \\
\left(\mathrm{cm}^{-1}\right)\end{array}$ & $\begin{array}{c}\lambda \\
(\mathrm{nm})\end{array}$ & $f^{[\mathrm{a}]}$ & $\begin{array}{c}\text { Major } \\
\text { excitations }^{[\mathrm{b}]}\end{array}$ \\
\hline 1 & 22269 & 449.1 & 0.000 & H-1»LUMO (99\%) \\
\hline 2 & 24264 & 412.1 & 0.557 & $\begin{array}{l}\text { HOMO»LUMO } \\
(92 \%)\end{array}$ \\
\hline 3 & 27321 & 366.0 & 0.000 & H-2»LUMO (100\%) \\
\hline 4 & 27851 & 359.1 & 0.000 & $\begin{array}{l}\text { H-6»LUMO (11\%) } \\
\text { H-3»LUMO (87\%) }\end{array}$ \\
\hline 5 & 30764 & 325.1 & 0.000 & $\begin{array}{l}\text { H-6»LUMO (85\%) } \\
\text { H-3»LUMO (12\%) }\end{array}$ \\
\hline 6 & 31343 & 319.1 & 0.040 & $\begin{array}{l}\text { H-4»LUMO (80\%) } \\
\text { HOMO»L+2 (15\%) }\end{array}$ \\
\hline 7 & 33625 & 297.4 & 0.000 & $\mathrm{H}-8 »$ LUMO (94\%) \\
\hline 8 & 34030 & 293.9 & 0.018 & H-5»LUMO (92\%) \\
\hline 9 & 35132 & 284.6 & 0.024 & $\begin{array}{l}\text { H-7»LUMO (60\%) } \\
\text { HOMO»L+1 (31\%) }\end{array}$ \\
\hline 10 & 36654 & 272.8 & 0.000 & $\begin{array}{l}\text { H-7»LUMO (12\%) } \\
\text { HOMO»L+1 (52\%) } \\
\text { HOMO»L+2 (26\%) }\end{array}$ \\
\hline 11 & 39448 & 253.5 & 0.232 & $\begin{array}{l}\text { H-7»LUMO (21\%) } \\
\text { HOMO»L+1 (10\%) } \\
\text { HOMO»L+2 (46\%) }\end{array}$ \\
\hline 12 & 39513 & 253.1 & 0.121 & $H-1 » L+2(83 \%)$ \\
\hline 13 & 40764 & 245.3 & 1.009 & $\begin{array}{l}H-1 » L+1(65 \%) \\
H O M O » L+3(11 \%)\end{array}$ \\
\hline 14 & 41688 & 239.9 & 0.000 & $H-2 » L+1(98 \%)$ \\
\hline 15 & 42100 & 237.5 & 0.001 & HOMO»L+4 (94\%) \\
\hline 16 & 42213 & 236.9 & 0.000 & $\mathrm{H}-3 » \mathrm{~L}+1(88 \%)$ \\
\hline 17 & 42395 & 235.9 & 0.167 & HOMO»L+3 (80\%) \\
\hline 18 & 42829 & 233.5 & 0.006 & $\begin{array}{l}H-3 » L+3(27 \%) \\
H-3 » L+5(15 \%) \\
H-2 » L+4(52 \%)\end{array}$ \\
\hline 19 & 43211 & 231.4 & 0.206 & $\begin{array}{l}\mathrm{H}-1 » \mathrm{~L}+1 \text { (11\%) } \\
\text { HOMO»L+5 (74\%) }\end{array}$ \\
\hline 20 & 43502 & 229.9 & 0.018 & $\begin{array}{l}H-1 » L+3(52 \%) \\
H-1 » L+5(32 \%)\end{array}$ \\
\hline 21 & 43884 & 227.9 & 0.000 & H-9»LUMO (97\%) \\
\hline 22 & 44145 & 226.5 & 0.001 & $\mathrm{H}-2 » \mathrm{~L}+2(98 \%)$ \\
\hline 23 & 44852 & 223.0 & 0.000 & $\begin{array}{l}\mathrm{H}-10 » \mathrm{LUMO}(51 \%) \\
\mathrm{H}-6 » \mathrm{~L}+1(36 \%)\end{array}$ \\
\hline 24 & 45007 & 222.2 & 0.001 & $\begin{array}{l}\mathrm{H}-11 » \mathrm{LUMO}(68 \%) \\
\mathrm{H}-5 » \mathrm{~L}+1(21 \%)\end{array}$ \\
\hline 25 & 45259 & 221.0 & 0.000 & $H-3 » L+2(94 \%)$ \\
\hline 26 & 45344 & 220.5 & 0.000 & $\begin{array}{l}\mathrm{H}-10 » \mathrm{LUMO}(47 \%) \\
\mathrm{H}-6 » \mathrm{~L}+1(44 \%)\end{array}$ \\
\hline 27 & 45448 & 220.0 & 0.000 & $H-1 » L+4(98 \%)$ \\
\hline 28 & 45854 & 218.1 & 0.000 & H-16»LUMO (93\%) \\
\hline 29 & 45959 & 217.6 & 0.000 & $\begin{array}{l}H-1 » L+3(40 \%) \\
H-1 » L+5(58 \%)\end{array}$ \\
\hline 30 & 46569 & 214.7 & 0.152 & $H-4 » L+1(76 \%)$ \\
\hline 31 & 46879 & 213.3 & 0.000 & $\begin{array}{l}H-8 » L+1(26 \%) \\
H-6 » L+3(14 \%) \\
H-3 » L+3(19 \%) \\
H-3 » L+5(24 \%)\end{array}$ \\
\hline
\end{tabular}

\begin{tabular}{|c|c|c|c|c|}
\hline No. & $\begin{array}{l}\text { Energy } \\
\left(\mathrm{cm}^{-1}\right)\end{array}$ & $\begin{array}{c}\lambda \\
(\mathrm{nm})\end{array}$ & $f^{[\mathrm{a}]}$ & $\begin{array}{c}\text { Major } \\
\text { excitations }^{[b]}\end{array}$ \\
\hline 32 & 46967 & 212.9 & 0.040 & $\begin{array}{l}\mathrm{H}-11 » \mathrm{LUMO}(11 \%) \\
\mathrm{H}-5 » \mathrm{~L}+1(64 \%)\end{array}$ \\
\hline 33 & 47145 & 212.1 & 0.000 & H-13»LUMO (93\%) \\
\hline 34 & 47177 & 212.0 & 0.000 & $\begin{array}{l}H-2 » L+3(58 \%) \\
H-2 » L+5(40 \%)\end{array}$ \\
\hline 35 & 47334 & 211.3 & 0.001 & $\mathrm{H}-12 » L U M O(94 \%)$ \\
\hline 36 & 48500 & 206.2 & 0.000 & $H-6 » L+2$ (93\%) \\
\hline 37 & 48736 & 205.2 & 0.005 & $\begin{array}{l}H-8 » L+1(42 \%) \\
H-3 » L+3(23 \%) \\
H-3 » L+5(26 \%)\end{array}$ \\
\hline 38 & 48770 & 205.0 & 0.000 & H-18»LUMO (91\%) \\
\hline 39 & 49088 & 203.7 & 0.139 & $\begin{array}{l}H-5 » L+2(48 \%) \\
H-4 » L+3(18 \%) \\
H-4 » L+5(12 \%)\end{array}$ \\
\hline 40 & 49346 & 202.7 & 0.025 & $\begin{array}{l}H-6 » L+4(11 \%) \\
H-3 » L+4(43 \%) \\
H-2 » L+3(10 \%) \\
H-2 » L+5(23 \%)\end{array}$ \\
\hline 41 & 49482 & 202.1 & 0.003 & $\begin{array}{l}\mathrm{H}-15 » L U M O(24 \%) \\
\mathrm{H}-14 » L U M O(73 \%)\end{array}$ \\
\hline 42 & 49941 & 200.2 & 0.006 & $\begin{array}{l}\mathrm{H}-15 » L \mathrm{LMO}(40 \%) \\
\mathrm{H}-7 » \mathrm{~L}+1(11 \%) \\
\mathrm{H}-7 » \mathrm{~L}+2(16 \%)\end{array}$ \\
\hline 43 & 50189 & 199.2 & 0.201 & $\begin{array}{l}\mathrm{H}-15 » L \mathrm{~L} M O(10 \%) \\
\mathrm{H}-7 » \mathrm{~L}+1(10 \%) \\
\mathrm{H}-7 » \mathrm{~L}+2(43 \%) \\
\mathrm{H}-4 » \mathrm{~L}+2(19 \%)\end{array}$ \\
\hline 44 & 50566 & 197.8 & 0.451 & $\begin{array}{l}H-7 » L+1(49 \%) \\
H-5 » L+3(12 \%) \\
H-4 » L+2(16 \%)\end{array}$ \\
\hline 45 & 50708 & 197.2 & 0.000 & $\begin{array}{l}H-7 » L+4(56 \%) \\
H-4 » L+4(43 \%)\end{array}$ \\
\hline 46 & 50735 & 197.1 & 0.007 & $\begin{array}{l}H-8 » L+1(21 \%) \\
H-6 » L+3(62 \%)\end{array}$ \\
\hline 47 & 50807 & 196.8 & 0.000 & H-17»LUMO (91\%) \\
\hline 48 & 50877 & 196.6 & 0.004 & $\begin{array}{l}H-6 » L+4(73 \%) \\
H-2 » L+5(11 \%)\end{array}$ \\
\hline 49 & 51067 & 195.8 & 0.033 & HOMO»L+6 (80\%) \\
\hline 50 & 51355 & 194.7 & 0.017 & $\begin{array}{l}H-8 » L+2(47 \%) \\
H-6 » L+3(11 \%) \\
H-6 » L+5(31 \%)\end{array}$ \\
\hline
\end{tabular}

[a] Oscillator strength. [b] Contributions smaller than $10 \%$ are not included. $\mathrm{H}=\mathrm{HOMO}, \mathrm{L}=\mathrm{LUMO}$. Orbitals are numbered consecutively regardless of possible degeneracies. 
Table S10. Electronic transitions calculated for 5 using the TDA/PCM(DMSO)/B3LYP/6-31G(d,p) level of theory.

\begin{tabular}{|c|c|c|c|c|}
\hline No. & $\begin{array}{l}\text { Energy } \\
\left(\mathrm{cm}^{-1}\right)\end{array}$ & $\begin{array}{c}\lambda \\
(\mathrm{nm})\end{array}$ & $f^{[a]}$ & $\begin{array}{c}\text { Major } \\
\text { excitations }^{[\mathrm{b}]}\end{array}$ \\
\hline 1 & 22025 & 454.0 & 0.001 & H-1»LUMO (99\%) \\
\hline 2 & 24038 & 416.0 & 0.459 & $\begin{array}{l}\text { HOMO»LUMO } \\
(91 \%)\end{array}$ \\
\hline 3 & 31791 & 314.6 & 0.080 & $\begin{array}{l}\text { H-2»LUMO (75\%) } \\
\text { HOMO»L+2 (20\%) }\end{array}$ \\
\hline 4 & 32253 & 310.1 & 0.000 & H-4»LUMO (96\%) \\
\hline 5 & 33900 & 295.0 & 0.001 & H-3»LUMO (90\%) \\
\hline 6 & 34660 & 288.5 & 0.000 & HOMO»L+1 (93\%) \\
\hline 7 & 36857 & 271.3 & 0.000 & H-5»LUMO (91\%) \\
\hline 8 & 38673 & 258.6 & 0.173 & $\begin{array}{l}\text { H-2»LUMO (13\%) } \\
\text { HOMO»L+2 (71\%) }\end{array}$ \\
\hline 9 & 39363 & 254.0 & 0.043 & $\begin{array}{l}H-1 » L+1(15 \%) \\
H-1 » L+2(75 \%)\end{array}$ \\
\hline 10 & 40067 & 249.6 & 1.125 & $\begin{array}{l}H-1 » L+1(67 \%) \\
H-1 » L+2(11 \%)\end{array}$ \\
\hline 11 & 42946 & 232.9 & 0.049 & $\begin{array}{l}H-2 » L+1(14 \%) \\
\text { HOMO»L+3 (74\%) }\end{array}$ \\
\hline 12 & 43693 & 228.9 & 0.035 & $\begin{array}{l}\mathrm{H}-6 » \mathrm{LUMO}(34 \%) \\
\mathrm{H}-3 » \mathrm{~L}+1(17 \%) \\
\mathrm{H}-1 » \mathrm{~L}+3(36 \%)\end{array}$ \\
\hline 13 & 44102 & 226.7 & 0.003 & $\begin{array}{l}\mathrm{H}-6 » L \mathrm{~L} M O(14 \%) \\
\mathrm{H}-3 » \mathrm{~L}+1(30 \%) \\
\mathrm{H}-1 » \mathrm{~L}+3(40 \%)\end{array}$ \\
\hline 14 & 44805 & 223.2 & 0.000 & $H-4 » L+1(82 \%)$ \\
\hline 15 & 45475 & 219.9 & 0.157 & $H-2 » L+1(72 \%)$ \\
\hline 16 & 45556 & 219.5 & 0.021 & $\begin{array}{l}\mathrm{H}-7 » L U M O(63 \%) \\
\mathrm{H}-6 » L U M O(12 \%) \\
\mathrm{H}-1 » \mathrm{~L}+3(14 \%)\end{array}$ \\
\hline 17 & 45923 & 217.8 & 0.000 & H-9»LUMO (99\%) \\
\hline 18 & 46787 & 213.7 & 0.062 & $\begin{array}{l}\text { H-7»LUMO (12\%) } \\
H-6 » L U M O(32 \%) \\
H-3 » L+1(39 \%) \\
H-3 » L+2(10 \%)\end{array}$ \\
\hline 19 & 48183 & 207.5 & 0.000 & $\mathrm{H}-10 »$ LUMO (94\%) \\
\hline 20 & 49179 & 203.3 & 0.001 & $\begin{array}{l}H-5 » L+1(74 \%) \\
H-4 » L+3(19 \%)\end{array}$ \\
\hline 21 & 49370 & 202.6 & 0.243 & $\begin{array}{l}H-3 » L+2(53 \%) \\
H-2 » L+3(25 \%)\end{array}$ \\
\hline 22 & 50035 & 199.9 & 0.013 & $\begin{array}{l}\mathrm{H}-8 » \text { LUMO (65\%) } \\
\mathrm{H}-3 » \mathrm{~L}+3(17 \%)\end{array}$ \\
\hline 23 & 50646 & 197.5 & 0.000 & $\begin{array}{l}\mathrm{H}-11 » \mathrm{LUMO}(17 \%) \\
\mathrm{H}-4 » \mathrm{~L}+2(81 \%)\end{array}$ \\
\hline 24 & 50863 & 196.6 & 0.000 & $\begin{array}{l}\mathrm{H}-11 » \mathrm{LUMO}(78 \%) \\
\mathrm{H}-4 » \mathrm{~L}+2(18 \%)\end{array}$ \\
\hline 25 & 51101 & 195.7 & 0.131 & HOMO»L+4 (84\%) \\
\hline 26 & 51758 & 193.2 & 0.603 & $\begin{array}{l}H-3 » L+3(37 \%) \\
H-2 » L+2(53 \%)\end{array}$ \\
\hline 27 & 53094 & 188.3 & 0.516 & $\begin{array}{l}H-2 » L+2(12 \%) \\
H-1 » L+4(57 \%)\end{array}$ \\
\hline 28 & 53261 & 187.8 & 0.000 & $\begin{array}{l}\mathrm{H}-5 » \mathrm{~L}+1(22 \%) \\
\mathrm{H}-4 » \mathrm{~L}+3(71 \%)\end{array}$ \\
\hline
\end{tabular}

\begin{tabular}{|c|c|c|c|c|}
\hline No. & $\begin{array}{l}\text { Energy } \\
\left(\mathrm{cm}^{-1}\right)\end{array}$ & $\begin{array}{c}\lambda \\
(\mathrm{nm})\end{array}$ & $f^{[a]}$ & $\begin{array}{c}\text { Major } \\
\text { excitations }^{[b]}\end{array}$ \\
\hline 29 & 54333 & 184.0 & 0.557 & $\begin{array}{l}H-3 » L+2(12 \%) \\
H-2 » L+3(66 \%)\end{array}$ \\
\hline 30 & 54943 & 182.0 & 0.000 & $H-5 » L+2(95 \%)$ \\
\hline 31 & 55503 & 180.2 & 0.028 & $\begin{array}{l}H-3 » L+3(31 \%) \\
H-2 » L+2(14 \%) \\
H-1 » L+4(16 \%) \\
H O M O » L+5(10 \%)\end{array}$ \\
\hline 32 & 56413 & 177.3 & 0.000 & $\begin{array}{l}\mathrm{H}-13 » \mathrm{LUMO}(71 \%) \\
\mathrm{H}-5 » \mathrm{~L}+3(24 \%)\end{array}$ \\
\hline 33 & 56458 & 177.1 & 0.000 & $\mathrm{H}-12 » L U M O(96 \%)$ \\
\hline 34 & 57840 & 172.9 & 0.116 & $H-6 » L+1$ (81\%) \\
\hline 35 & 57893 & 172.7 & 0.000 & $\begin{array}{l}\mathrm{H}-13 » \mathrm{LUMO}(26 \%) \\
\mathrm{H}-5 » \mathrm{~L}+3(64 \%)\end{array}$ \\
\hline 36 & 58916 & 169.7 & 0.071 & $\begin{array}{l}H-7 » L+1(22 \%) \\
H-6 » L+2(59 \%) \\
H O M O » L+5(10 \%)\end{array}$ \\
\hline 37 & 59056 & 169.3 & 0.000 & $\begin{array}{l}\mathrm{H}-16 » L \text { LMO (10\%) } \\
\mathrm{H}-9 » \mathrm{~L}+1(82 \%)\end{array}$ \\
\hline 38 & 59297 & 168.6 & 0.200 & $\begin{array}{l}\mathrm{H}-2 » \mathrm{~L}+4(55 \%) \\
\mathrm{HOMO} » \mathrm{~L}+5(23 \%)\end{array}$ \\
\hline 39 & 59313 & 168.6 & 0.000 & HOMO»L+6 (92\%) \\
\hline 40 & 59456 & 168.2 & 0.060 & $\begin{array}{l}\mathrm{H}-14 » \mathrm{LUMO}(29 \%) \\
\mathrm{H}-3 » \mathrm{~L}+4(63 \%)\end{array}$ \\
\hline 41 & 59692 & 167.5 & 0.004 & $\begin{array}{l}H-7 » L+1(17 \%) \\
H-6 » L+2(24 \%) \\
H-2 » L+4(39 \%) \\
H O M O » L+5(14 \%)\end{array}$ \\
\hline 42 & 60989 & 164.0 & 0.007 & $\begin{array}{l}\mathrm{H}-14 » \mathrm{LUMO}(13 \%) \\
\mathrm{H}-8 » \mathrm{~L}+1(72 \%)\end{array}$ \\
\hline 43 & 61407 & 162.8 & 0.000 & $H-9 » L+2(97 \%)$ \\
\hline 44 & 61653 & 162.2 & 0.000 & $H-10 » L+1(85 \%)$ \\
\hline 45 & 61840 & 161.7 & 0.015 & $\begin{array}{l}H-14 » L U M O(41 \%) \\
H-3 » L+4(23 \%) \\
H-1 » L+5(11 \%)\end{array}$ \\
\hline 46 & 62104 & 161.0 & 0.050 & $\begin{array}{l}H-7 » L+1(18 \%) \\
H-7 » L+2(40 \%) \\
H O M O » L+5(16 \%)\end{array}$ \\
\hline 47 & 62460 & 160.1 & 0.002 & $H-1 » L+6(97 \%)$ \\
\hline 48 & 62846 & 159.1 & 0.264 & $\begin{array}{l}H-8 » L+1(13 \%) \\
H-1 » L+5(71 \%)\end{array}$ \\
\hline 49 & 63326 & 157.9 & 0.000 & $\begin{array}{l}\mathrm{H}-16 » \mathrm{LUMO}(10 \%) \\
\mathrm{H}-4 » \mathrm{~L}+4(78 \%)\end{array}$ \\
\hline 50 & 63471 & 157.6 & 0.000 & $\begin{array}{l}\mathrm{H}-16 » \text { LUMO (73\%) } \\
\mathrm{H}-4 » \mathrm{~L}+4(12 \%)\end{array}$ \\
\hline
\end{tabular}

[a] Oscillator strength. [b] Contributions smaller than $10 \%$ are not included. $\mathrm{H}=\mathrm{HOMO}, \mathrm{L}=$ LUMO. Orbitals are numbered consecutively regardless of possible degeneracies. 
Table S11. Electronic transitions calculated for 6 using the TDA/PCM(DMSO)/B3LYP/6-31G(d,p) level of theory.

\begin{tabular}{|c|c|c|c|c|}
\hline No. & $\begin{array}{l}\text { Energy } \\
\left(\mathrm{cm}^{-1}\right)\end{array}$ & $\begin{array}{c}\lambda \\
(\mathrm{nm})\end{array}$ & $f^{[a]}$ & $\begin{array}{c}\text { Major } \\
\text { excitations }^{[\mathrm{b}]}\end{array}$ \\
\hline \multirow[t]{2}{*}{1} & 20285 & 493.0 & 0.184 & H-1»LUMO (43\%) \\
\hline & & & & $\begin{array}{l}\text { HOMO»LUMO } \\
(54 \%)\end{array}$ \\
\hline \multirow[t]{2}{*}{2} & 23131 & 432.3 & 0.592 & H-1»LUMO (49\%) \\
\hline & & & & $\begin{array}{l}\text { HOMO»LUMO } \\
(41 \%)\end{array}$ \\
\hline 3 & 27284 & 366.5 & 0.003 & H-3»LUMO (92\%) \\
\hline 4 & 27538 & 363.1 & 0.009 & H-2»LUMO (90\%) \\
\hline \multirow[t]{2}{*}{5} & 31482 & 317.6 & 0.063 & H-4»LUMO (68\%) \\
\hline & & & & HOMO»L+2 (24\%) \\
\hline 6 & 31620 & 316.3 & 0.001 & H-6»LUMO (94\%) \\
\hline 7 & 33568 & 297.9 & 0.408 & HOMO»L+1 (92\%) \\
\hline 8 & 34462 & 290.2 & 0.002 & H-5»LUMO (88\%) \\
\hline 9 & 36187 & 276.3 & 0.001 & H-7»LUMO (95\%) \\
\hline \multirow[t]{2}{*}{10} & 36695 & 272.5 & 0.198 & HOMO»L+2 (50\%) \\
\hline & & & & HOMO»L+3 (20\%) \\
\hline 11 & 37619 & 265.8 & 0.907 & $H-1 » L+1(73 \%)$ \\
\hline \multirow[t]{2}{*}{12} & 38551 & 259.4 & 0.381 & HOMO»L+2 (13\%) \\
\hline & & & & HOMO»L+3 (39\%) \\
\hline \multirow[t]{2}{*}{13} & 39050 & 256.1 & 0.052 & $H-1 » L+2(64 \%)$ \\
\hline & & & & HOMO»L+3 (14\%) \\
\hline 14 & 41089 & 243.4 & 0.069 & $H-1 » L+3(55 \%)$ \\
\hline \multirow[t]{2}{*}{15} & 41195 & 242.7 & 0.001 & $H-2 » L+1(65 \%)$ \\
\hline & & & & HOMO»L+4 (19\%) \\
\hline \multirow[t]{3}{*}{16} & 41881 & 238.8 & 0.106 & H-8»LUMO (21\%) \\
\hline & & & & $H-1 » L+3(13 \%)$ \\
\hline & & & & HOMO»L+4 (14\%) \\
\hline \multirow[t]{3}{*}{17} & 42130 & 237.4 & 0.035 & H-8»LUMO (13\%) \\
\hline & & & & $H-3 » L+1(54 \%)$ \\
\hline & & & & HOMO»L+4 (12\%) \\
\hline 18 & 43240 & 231.3 & 0.027 & $H-2 » L+2(73 \%)$ \\
\hline \multirow[t]{2}{*}{19} & 43392 & 230.5 & 0.064 & H-8»LUMO (42\%) \\
\hline & & & & HOMO»L+4 (35\%) \\
\hline \multirow[t]{2}{*}{20} & 44295 & 225.8 & 0.124 & $H-3 » L+2(82 \%)$ \\
\hline & & & & $H-2 » L+2(10 \%)$ \\
\hline 21 & 45011 & 222.2 & 0.126 & H-9»LUMO (57\%) \\
\hline \multirow[t]{2}{*}{22} & 45430 & 220.1 & 0.274 & $H-4 » L+1(10 \%)$ \\
\hline & & & & $H-2 » L+3(44 \%)$ \\
\hline 23 & 45436 & 220.1 & 0.000 & $H-6 » L+1(87 \%)$ \\
\hline 24 & 45701 & 218.8 & 0.006 & $\mathrm{H}-4 » \mathrm{~L}+1$ (71\%) \\
\hline 25 & 45736 & 218.6 & 0.000 & $\mathrm{H}-11 »$ LUMO (99\%) \\
\hline \multirow[t]{3}{*}{26} & 45852 & 218.1 & 0.020 & H-9»LUMO (12\%) \\
\hline & & & & $H-3 » L+3(52 \%)$ \\
\hline & & & & HOMO»L+5 (11\%) \\
\hline \multirow[t]{3}{*}{27} & 46709 & 214.1 & 0.016 & $H-5 » L+1(42 \%)$ \\
\hline & & & & $H-1 » L+4(18 \%)$ \\
\hline & & & & HOMO»L+5 (17\%) \\
\hline \multirow[t]{3}{*}{28} & 47312 & 211.4 & 0.036 & $H-5 » L+1(26 \%)$ \\
\hline & & & & $H-1 » L+4(14 \%)$ \\
\hline & & & & HOMO»L+5 (18\%) \\
\hline \multirow[t]{5}{*}{29} & 48011 & 208.3 & 0.085 & $H-5 » L+2(11 \%)$ \\
\hline & & & & $H-4 » L+3(11 \%)$ \\
\hline & & & & $H-3 » L+3(14 \%)$ \\
\hline & & & & $H-1 » L+4(19 \%)$ \\
\hline & & & & HOMO»L+5 (20\%) \\
\hline 30 & 48236 & 207.3 & 0.000 & $\mathrm{H}-12 »$ LUMO (96\%) \\
\hline \multirow[t]{2}{*}{31} & 48790 & 205.0 & 0.001 & $H-7 » L+1(78 \%)$ \\
\hline & & & & $H-6 » L+3(14 \%)$ \\
\hline
\end{tabular}

\begin{tabular}{|c|c|c|c|c|}
\hline No. & $\begin{array}{l}\text { Energy } \\
\left(\mathrm{cm}^{-1}\right)\end{array}$ & $\begin{array}{c}\lambda \\
(\mathrm{nm})\end{array}$ & $f^{[a]}$ & $\begin{array}{c}\text { Major } \\
\text { excitations }^{[\mathrm{b}]}\end{array}$ \\
\hline \multirow[t]{2}{*}{32} & 48867 & 204.6 & 0.072 & $H-5 » L+2(33 \%)$ \\
\hline & & & & $\mathrm{H}-4 » \mathrm{~L}+3(33 \%)$ \\
\hline \multirow[t]{2}{*}{33} & 49285 & 202.9 & 0.041 & $\mathrm{H}-10 »$ LUMO (60\%) \\
\hline & & & & $H-5 » L+3(10 \%)$ \\
\hline \multirow[t]{2}{*}{34} & 49886 & 200.5 & 0.076 & $\mathrm{H}-2 » \mathrm{~L}+4(26 \%)$ \\
\hline & & & & $\mathrm{H}-1 » \mathrm{~L}+5(40 \%)$ \\
\hline \multirow[t]{2}{*}{35} & 50095 & 199.6 & 0.000 & $H-6 » L+2(71 \%)$ \\
\hline & & & & $H-6 » L+3(14 \%)$ \\
\hline \multirow[t]{2}{*}{36} & 50659 & 197.4 & 0.198 & $\mathrm{H}-3 » \mathrm{~L}+4(40 \%)$ \\
\hline & & & & HOMO»L+6 (36\%) \\
\hline \multirow[t]{3}{*}{37} & 50762 & 197.0 & 0.121 & $H-5 » L+3(16 \%)$ \\
\hline & & & & $H-3 » L+4(12 \%)$ \\
\hline & & & & HOMO»L+6 (32\%) \\
\hline \multirow[t]{3}{*}{38} & 50771 & 197.0 & 0.000 & $\mathrm{H}-14 » \mathrm{LUMO}(19 \%)$ \\
\hline & & & & $H-6 » L+2(25 \%)$ \\
\hline & & & & $H-6 » L+3(37 \%)$ \\
\hline \multirow[t]{3}{*}{39} & 51291 & 195.0 & 0.000 & $\mathrm{H}-16 »$ LUMO (14\%) \\
\hline & & & & $\mathrm{H}-14 » \mathrm{LUMO}(49 \%)$ \\
\hline & & & & $H-6 » L+3(26 \%)$ \\
\hline \multirow[t]{2}{*}{40} & 51609 & 193.8 & 0.069 & $H-2 » L+4(16 \%)$ \\
\hline & & & & $H-1 » L+5(34 \%)$ \\
\hline \multirow[t]{4}{*}{41} & 51989 & 192.3 & 0.211 & $H-5 » L+3(21 \%)$ \\
\hline & & & & $H-4 » L+2(19 \%)$ \\
\hline & & & & $H-2 » L+4(12 \%)$ \\
\hline & & & & $H-2 » L+5(16 \%)$ \\
\hline \multirow[t]{2}{*}{42} & 52554 & 190.3 & 0.407 & $\mathrm{H}-13 » \mathrm{LUMO}(16 \%)$ \\
\hline & & & & $H-4 » L+2(25 \%)$ \\
\hline \multirow[t]{2}{*}{43} & 53210 & 187.9 & 0.025 & $\mathrm{H}-13 » \mathrm{LUMO}(63 \%)$ \\
\hline & & & & $H-1 » L+6(11 \%)$ \\
\hline \multirow[t]{4}{*}{44} & 53396 & 187.3 & 0.407 & $H-5 » L+2(19 \%)$ \\
\hline & & & & $H-5 » L+3(15 \%)$ \\
\hline & & & & $H-4 » L+3(24 \%)$ \\
\hline & & & & $H-1 » L+5(10 \%)$ \\
\hline \multirow[t]{2}{*}{45} & 53751 & 186.0 & 0.000 & $H-7 » L+2(46 \%)$ \\
\hline & & & & $H-7 » L+3(47 \%)$ \\
\hline \multirow[t]{4}{*}{46} & 54053 & 185.0 & 0.000 & $\mathrm{H}-16 » \mathrm{LUMO}(10 \%)$ \\
\hline & & & & $\mathrm{H}-14 »$ LUMO (10\%) \\
\hline & & & & $H-7 » L+2(36 \%)$ \\
\hline & & & & $H-7 » L+3(35 \%)$ \\
\hline \multirow[t]{5}{*}{47} & 54204 & 184.5 & 0.000 & $\mathrm{H}-16 »$ LUMO (34\%) \\
\hline & & & & $\mathrm{H}-15 »$ LUMO (20\%) \\
\hline & & & & $\mathrm{H}-14 »$ LUMO (17\%) \\
\hline & & & & $H-7 » L+2(15 \%)$ \\
\hline & & & & $H-7 » L+3(10 \%)$ \\
\hline \multirow[t]{2}{*}{48} & 54390 & 183.9 & 0.120 & $\mathrm{H}-4 » \mathrm{~L}+4(30 \%)$ \\
\hline & & & & $H-1 » L+6(38 \%)$ \\
\hline \multirow[t]{2}{*}{49} & 54838 & 182.4 & 0.000 & $\mathrm{H}-16 »$ LUMO (28\%) \\
\hline & & & & $\mathrm{H}-15 »$ LUMO (66\%) \\
\hline \multirow[t]{3}{*}{50} & 55336 & 180.7 & 0.229 & $H-4 » L+4(31 \%)$ \\
\hline & & & & $H-3 » L+5(18 \%)$ \\
\hline & & & & $H-1 » L+6(11 \%)$ \\
\hline
\end{tabular}

[a] Oscillator strength. [b] Contributions smaller than $10 \%$ are not included. $\mathrm{H}=\mathrm{HOMO}, \mathrm{L}=\mathrm{LUMO}$. Orbitals are numbered consecutively regardless of possible degeneracies. 
Table S12. Electronic transitions calculated for 7 using the TDA/PCM(DMSO)/B3LYP/6-31G(d,p) level of theory.

\begin{tabular}{|c|c|c|c|c|}
\hline No. & $\begin{array}{l}\text { Energy } \\
\left(\mathrm{cm}^{-1}\right)\end{array}$ & $\begin{array}{c}\lambda \\
(\mathrm{nm})\end{array}$ & $f^{[a]}$ & $\begin{array}{c}\text { Major } \\
\text { excitations }^{[\mathrm{b}]}\end{array}$ \\
\hline \multirow[t]{2}{*}{1} & 20337 & 491.7 & 0.639 & H-2»LUMO (10\%) \\
\hline & & & & $\begin{array}{l}\text { HOMO»LUMO } \\
(86 \%)\end{array}$ \\
\hline \multirow[t]{2}{*}{2} & 20980 & 476.6 & 0.030 & H-2»LUMO (45\%) \\
\hline & & & & H-1»LUMO (46\%) \\
\hline \multirow[t]{2}{*}{3} & 23856 & 419.2 & 0.336 & H-2»LUMO (36\%) \\
\hline & & & & H-1»LUMO (49\%) \\
\hline 4 & 27284 & 366.5 & 0.005 & H-3»LUMO (89\%) \\
\hline 5 & 29623 & 337.6 & 0.228 & HOMO»L+1 (86\%) \\
\hline \multirow[t]{2}{*}{6} & 31263 & 319.9 & 0.041 & H-4»LUMO (65\%) \\
\hline & & & & HOMO»L+2 (21\%) \\
\hline 7 & 31669 & 315.8 & 0.001 & H-7»LUMO (94\%) \\
\hline 8 & 32888 & 304.1 & 0.370 & $\mathrm{H}-1 » \mathrm{~L}+1$ (78\%) \\
\hline \multirow[t]{2}{*}{9} & 33484 & 298.6 & 0.059 & H-5»LUMO (58\%) \\
\hline & & & & $\mathrm{H}-2 » \mathrm{~L}+1(28 \%)$ \\
\hline \multirow[t]{2}{*}{10} & 34238 & 292.1 & 0.418 & H-5»LUMO (27\%) \\
\hline & & & & $\mathrm{H}-2 » \mathrm{~L}+1$ (48\%) \\
\hline \multirow[t]{2}{*}{11} & 35524 & 281.5 & 0.447 & $H-3 » L+1(26 \%)$ \\
\hline & & & & HOMO»L+3 (44\%) \\
\hline \multirow[t]{2}{*}{12} & 35944 & 278.2 & 0.115 & H-6»LUMO (63\%) \\
\hline & & & & HOMO»L+2 (19\%) \\
\hline 13 & 36260 & 275.8 & 0.001 & H-8»LUMO (95\%) \\
\hline \multirow[t]{2}{*}{14} & 36799 & 271.7 & 0.081 & H-6»LUMO (20\%) \\
\hline & & & & HOMO»L+2 (47\%) \\
\hline \multirow[t]{3}{*}{15} & 37484 & 266.8 & 0.117 & $\mathrm{H}-1 » \mathrm{~L}+2(11 \%)$ \\
\hline & & & & HOMO»L+3 (27\%) \\
\hline & & & & HOMO»L+4 (29\%) \\
\hline \multirow[t]{3}{*}{16} & 38310 & 261.0 & 0.102 & $H-2 » L+2(12 \%)$ \\
\hline & & & & $H-1 » L+2(44 \%)$ \\
\hline & & & & HOMO»L+4 (30\%) \\
\hline \multirow[t]{2}{*}{17} & 38978 & 256.6 & 0.273 & $H-2 » L+2(40 \%)$ \\
\hline & & & & $H-1 » L+2(25 \%)$ \\
\hline \multirow[t]{3}{*}{18} & 39267 & 254.7 & 0.151 & $H-3 » L+1(23 \%)$ \\
\hline & & & & $H-2 » L+2(18 \%)$ \\
\hline & & & & HOMO»L+4 (13\%) \\
\hline 19 & 40201 & 248.8 & 0.383 & $H-1 » L+3(53 \%)$ \\
\hline \multirow[t]{2}{*}{20} & 40618 & 246.2 & 0.038 & $\mathrm{H}-2 » \mathrm{~L}+3(58 \%)$ \\
\hline & & & & $H-1 » L+4(22 \%)$ \\
\hline \multirow[t]{3}{*}{21} & 41736 & 239.6 & 0.063 & H-9»LUMO (26\%) \\
\hline & & & & $H-1 » L+4(21 \%)$ \\
\hline & & & & HOMO»L+5 (27\%) \\
\hline \multirow[t]{3}{*}{22} & 41985 & 238.2 & 0.150 & H-9»LUMO (38\%) \\
\hline & & & & $H-2 » L+4(13 \%)$ \\
\hline & & & & $H-1 » L+4(11 \%)$ \\
\hline \multirow[t]{3}{*}{23} & 42198 & 237.0 & 0.017 & $H-5 » L+1(36 \%)$ \\
\hline & & & & $H-4 » L+1(20 \%)$ \\
\hline & & & & $H-1 » L+4(13 \%)$ \\
\hline 24 & 42454 & 235.5 & 0.000 & $H-7 » L+1(90 \%)$ \\
\hline 25 & 42601 & 234.7 & 0.015 & $H-5 » L+1(22 \%)$ \\
\hline & & & & $H-4 » L+1(55 \%)$ \\
\hline 26 & 43275 & 231.1 & 0.092 & H-9»LUMO (12\%) \\
\hline & & & & $H-5 » L+1(13 \%)$ \\
\hline & & & & $H-3 » L+2(18 \%)$ \\
\hline & & & & $H-2 » L+4(30 \%)$ \\
\hline 27 & 43768 & 228.5 & 0.194 & H-10»LUMO (31\%) \\
\hline & & & & $H-3 » L+2(32 \%)$ \\
\hline 28 & 44196 & 226.3 & 0.011 & $\mathrm{H}-10 »$ LUMO (17\%) \\
\hline & & & & $H-6 » L+1(52 \%)$ \\
\hline & & & & HOMO»L+6 (13\%) \\
\hline
\end{tabular}

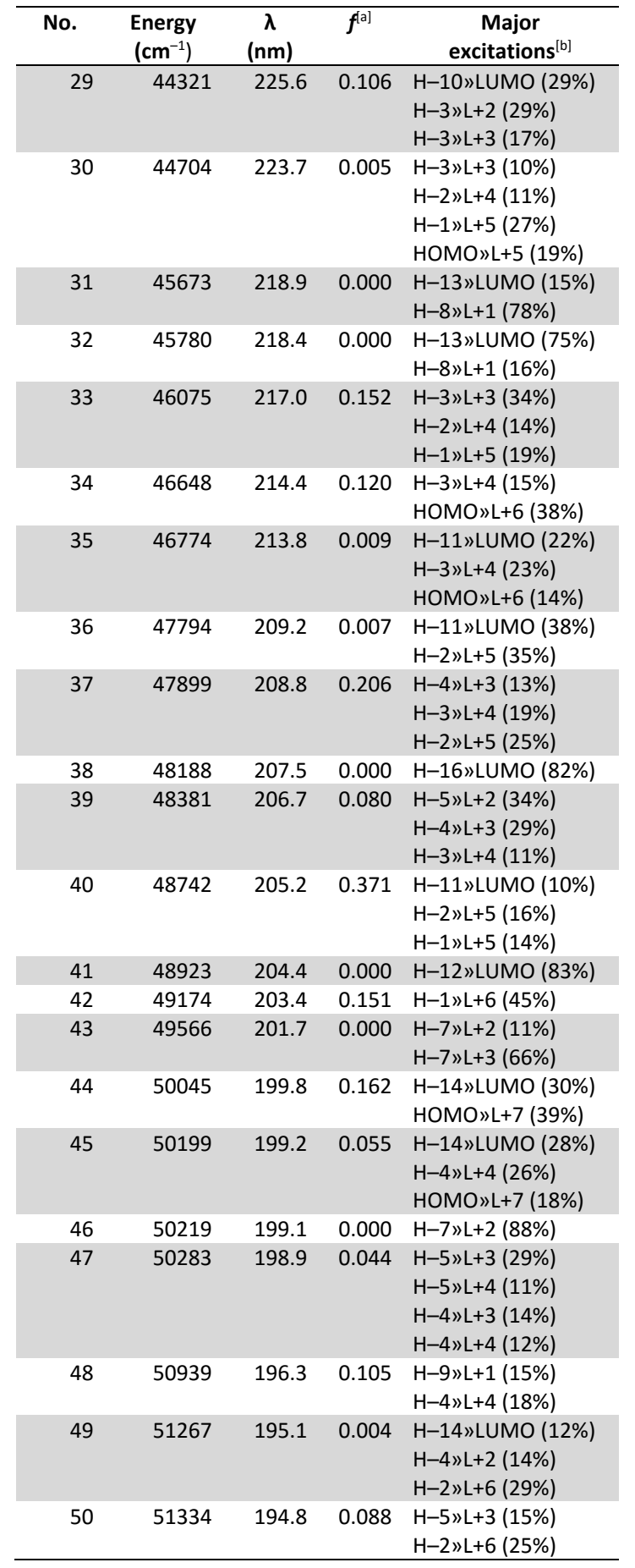

[a] Oscillator strength. [b] Contributions smaller than $10 \%$ are not included. $\mathrm{H}=\mathrm{HOMO}, \mathrm{L}=$ LUMO. Orbitals are numbered consecutively regardless of possible degeneracies. 
Table S13. Electronic transitions calculated for 8 using the TDA/PCM(DMSO)/B3LYP/6-31G(d,p) level of theory.

\begin{tabular}{|c|c|c|c|c|c|c|c|c|c|}
\hline No. & $\begin{array}{l}\text { Energy } \\
\left(\mathrm{cm}^{-1}\right)\end{array}$ & $\begin{array}{c}\lambda \\
(\mathrm{nm})\end{array}$ & $f^{[a]}$ & $\begin{array}{c}\text { Major } \\
\text { excitations }^{[\mathrm{b}]}\end{array}$ & No. & $\begin{array}{l}\text { Energy } \\
\left(\mathrm{cm}^{-1}\right)\end{array}$ & $\begin{array}{c}\lambda \\
(\mathrm{nm})\end{array}$ & $f^{[\mathrm{a}]}$ & $\begin{array}{c}\text { Major } \\
\text { excitations }^{[\mathrm{b}]}\end{array}$ \\
\hline 1 & 19824 & 504.4 & 0.069 & $\begin{array}{l}\text { H-1»LUMO (82\%) } \\
\text { HOMO»LUMO } \\
(11 \%)\end{array}$ & 23 & 40975 & 244.1 & 0.036 & $\begin{array}{l}\mathrm{H}-10 » \text { LUMO (11\%) } \\
\mathrm{H}-8 » \mathrm{LUMO}(40 \%) \\
\mathrm{H}-4 » \mathrm{~L}+2(14 \%)\end{array}$ \\
\hline 2 & 21997 & 454.6 & 0.682 & $\begin{array}{l}\text { H-1»LUMO (10\%) } \\
\text { HOMO»LUMO } \\
(76 \%)\end{array}$ & 24 & 41088 & 243.4 & 0.065 & $\begin{array}{l}\text { HOMO»L+4 (11\%) } \\
\text { HOMO»L+5 (44\%) }\end{array}$ \\
\hline \multirow[t]{2}{*}{3} & 25174 & 397.2 & 0.005 & $\begin{array}{l}\mathrm{H}-4 » \text { LUMO (47\%) } \\
\mathrm{H}-3 » \text { LUMO }(28 \%)\end{array}$ & 25 & 41322 & 242.0 & 0.008 & $\begin{array}{l}H-1 » L+4(12 \%) \\
H O M O » L+4(46 \%)\end{array}$ \\
\hline & & & & H-2»LUMO (13\%) & 26 & 41742 & 239.6 & 0.104 & $H-2 » L+2(15 \%)$ \\
\hline 4 & 25463 & 392.7 & 0.018 & HOMO»L+1 (83\%) & & & & & $\mathrm{H}-1 » \mathrm{~L}+4(30 \%)$ \\
\hline 5 & 26280 & 380.5 & 0.012 & H-2»LUMO (69\%) & & & & & HOMO»L+3 (11\%) \\
\hline 6 & 27021 & 370.1 & 0.873 & $\mathrm{H}-1 » \mathrm{~L}+1$ (90\%) & 27 & 42703 & 234.2 & 0.091 & $H-1 » L+5(34 \%)$ \\
\hline \multirow[t]{2}{*}{7} & 28937 & 345.6 & 0.005 & $\mathrm{H}-4 »$ LUMO (34\%) & & & & & HOMO»L+6 (17\%) \\
\hline & & & & H-3»LUMO (62\%) & 28 & 43199 & 231.5 & 0.086 & $\mathrm{H}-2 » \mathrm{~L}+3(71 \%)$ \\
\hline \multirow[t]{2}{*}{8} & 30320 & 329.8 & 0.005 & $\mathrm{H}-4 » \mathrm{~L}+1$ (42\%) & & & & & HOMO»L+6 (14\%) \\
\hline & & & & $\begin{array}{l}H-3 » L+1(25 \%) \\
H-2 » L+1(16 \%)\end{array}$ & 29 & 43753 & 228.6 & 0.039 & $\begin{array}{l}\text { H-9»LUMO (25\%) } \\
\text { H-8»LUMO (12\%) }\end{array}$ \\
\hline \multirow[t]{2}{*}{9} & 30921 & 323.4 & 0.044 & H-5»LUMO (54\%) & & & & & H-1»L+5 (14\%) \\
\hline & & & & $H-2 » L+1(14 \%)$ & 30 & 44078 & 226.9 & 0.000 & $\mathrm{H}-12 »$ LUMO (53\%) \\
\hline \multirow[t]{2}{*}{10} & 31052 & 322.0 & 0.085 & H-6»LUMO (16\%) & & & & & $\mathrm{H}-11 » \mathrm{LUMO}$ (39\%) \\
\hline & & & & $\begin{array}{l}\mathrm{H}-5 » \operatorname{LUMO}(19 \%) \\
\mathrm{H}-2 » L+1(47 \%)\end{array}$ & 31 & 44338 & 225.5 & 0.022 & $\begin{array}{l}\text { H-10»LUMO (61\%) } \\
\text { H-8»LUMO (12\%) }\end{array}$ \\
\hline 11 & 32777 & 305.1 & 0.022 & $\begin{array}{l}\mathrm{H}-6 » \text { LUMO (51\%) } \\
\mathrm{H}-3 » \mathrm{~L}+1(18 \%)\end{array}$ & 32 & 44454 & 225.0 & 0.121 & $\begin{array}{l}\text { H-9»LUMO (20\%) } \\
\text { HOMO»L+6 (49\%) }\end{array}$ \\
\hline 12 & 33157 & 301.6 & 0.007 & $\begin{array}{l}H-2 » L+1(10 \%) \\
H-6 » L U M O(23 \%) \\
H-4 » L+1(22 \%) \\
H-3 » L+1(34 \%)\end{array}$ & 33 & 44723 & 223.6 & 0.000 & $\begin{array}{l}H-4 » L+3(28 \%) \\
H-4 » L+4(22 \%) \\
H-3 » L+3(20 \%) \\
H-3 » L+4(12 \%)\end{array}$ \\
\hline 13 & 34459 & 290.2 & 0.165 & HOMO»L+2 (86\%) & 34 & 45162 & 221.4 & 0.000 & $\mathrm{H}-8 » \mathrm{~L}+1(25 \%)$ \\
\hline 14 & 35464 & 282.0 & 0.003 & $H-5 » L+1(85 \%)$ & & & & & $H-4 » L+3(15 \%)$ \\
\hline 15 & 36108 & 276.9 & 0.011 & $\begin{array}{l}H-6 » L+1(62 \%) \\
H-1 » L+2(12 \%)\end{array}$ & & & & & $\begin{array}{l}H-4 » L+4(12 \%) \\
H-3 » L+3(12 \%)\end{array}$ \\
\hline 16 & 36608 & 273.2 & 0.581 & $\begin{array}{l}\mathrm{H}-7 » \operatorname{LUMO}(16 \%) \\
\mathrm{H}-1 » \mathrm{~L}+2(71 \%)\end{array}$ & 35 & 45246 & 221.0 & 0.023 & $\begin{array}{l}H-8 » L+1(27 \%) \\
H-4 » L+3(11 \%)\end{array}$ \\
\hline 17 & 36988 & 270.4 & 0.042 & $\begin{array}{l}H-7 » L U M O(63 \%) \\
H-6 » L+1(20 \%)\end{array}$ & & & & & $\begin{array}{l}H-4 » L+4(10 \%) \\
H-3 » L+3(10 \%)\end{array}$ \\
\hline \multirow[t]{2}{*}{18} & 38007 & 263.1 & 0.049 & $\mathrm{H}-1 » \mathrm{~L}+3$ (17\%) & 36 & 45487 & 219.8 & 0.022 & $H-5 » L+2(84 \%)$ \\
\hline & & & & $\begin{array}{l}\text { HOMO»L+3 (43\%) } \\
\text { HOMO»L+4 (11\%) }\end{array}$ & 37 & 45722 & 218.7 & 0.017 & $\begin{array}{l}H-6 » L+2(49 \%) \\
H-2 » L+4(18 \%)\end{array}$ \\
\hline \multirow[t]{3}{*}{19} & 38882 & 257.2 & 0.210 & $H-7 » L+1(11 \%)$ & & & & & $H-1 » L+6(11 \%)$ \\
\hline & & & & $\begin{array}{l}H-3 » L+2(10 \%) \\
H-1 » L+3(50 \%)\end{array}$ & 38 & 46297 & 216.0 & 0.200 & $\begin{array}{l}H-6 » L+2(24 \%) \\
H-1 » L+6(29 \%)\end{array}$ \\
\hline & & & & $H-1 » L+4(11 \%)$ & 39 & 46371 & 215.7 & 0.131 & $H-3 » L+2(10 \%)$ \\
\hline \multirow[t]{2}{*}{20} & 39663 & 252.1 & 0.020 & $\begin{array}{l}H-7 » L+1(38 \%) \\
H-3 » L+2(19 \%)\end{array}$ & & & & & $\begin{array}{l}H-2 » L+5(25 \%) \\
H-1 » L+6(28 \%)\end{array}$ \\
\hline & & & & $H-1 » L+3(10 \%)$ & 40 & 47284 & 211.5 & 0.027 & $H-6 » L+3(11 \%)$ \\
\hline \multirow[t]{2}{*}{21} & 40086 & 249.5 & 0.005 & $H-4 » L+2(25 \%)$ & & & & & $\mathrm{H}-2 » \mathrm{~L}+4(23 \%)$ \\
\hline & & & & $\begin{array}{l}H-3 » L+2(12 \%) \\
H-2 » L+2(46 \%)\end{array}$ & 41 & 47484 & 210.6 & 0.052 & $\begin{array}{l}H-4 » L+3(30 \%) \\
H-3 » L+3(39 \%)\end{array}$ \\
\hline \multirow[t]{8}{*}{22} & 40884 & 244.6 & 0.033 & $\mathrm{H}-8 »$ LUMO (21\%) & & & & & $H-2 » L+5(15 \%)$ \\
\hline & & & & $H-7 » L+1(10 \%)$ & 42 & 47585 & 210.2 & 0.000 & $\mathrm{H}-14 »$ LUMO (43\%) \\
\hline & & & & $H-4 » L+2(15 \%)$ & & & & & $\mathrm{H}-13 »$ LUMO (46\%) \\
\hline & & & & $\mathrm{H}-2 » \mathrm{~L}+2(15 \%)$ & 43 & 47867 & 208.9 & 0.139 & $H-9 » L+1$ (10\%) \\
\hline & & & & HOMO»L+5 (15\%) & & & & & $H-4 » L+3(11 \%)$ \\
\hline & & & & & & & & & $H-3 » L+3(12 \%)$ \\
\hline & & & & & & & & & $H-3 » L+5(12 \%)$ \\
\hline & & & & & & & & & $H-2 » L+5(16 \%)$ \\
\hline
\end{tabular}




\begin{tabular}{|c|c|c|c|c|}
\hline No. & $\begin{array}{l}\text { Energy } \\
\left(\mathrm{cm}^{-1}\right)\end{array}$ & $\begin{array}{c}\lambda \\
(\mathrm{nm})\end{array}$ & $f^{[\mathrm{a}]}$ & $\begin{array}{c}\text { Major } \\
\text { excitations }^{[\mathrm{b}]}\end{array}$ \\
\hline 44 & 48095 & 207.9 & 0.003 & $\begin{array}{l}\mathrm{H}-12 » \mathrm{LUMO}(16 \%) \\
\mathrm{H}-11 » \mathrm{LUMO}(23 \%) \\
\mathrm{H}-3 » \mathrm{~L}+5(11 \%)\end{array}$ \\
\hline 45 & 48548 & 206.0 & 0.112 & $\begin{array}{l}\mathrm{H}-12 » L U M O(11 \%) \\
H-11 » L U M O(14 \%) \\
H-9 » L+1(10 \%) \\
H-8 » L+1(12 \%)\end{array}$ \\
\hline 46 & 48674 & 205.4 & 0.032 & $\begin{array}{l}H-10 » L+1(23 \%) \\
H-4 » L+5(27 \%) \\
H-3 » L+6(12 \%)\end{array}$ \\
\hline 47 & 48736 & 205.2 & 0.041 & $\begin{array}{l}H-9 » L+1(27 \%) \\
H-6 » L+3(23 \%) \\
H-5 » L+4(14 \%)\end{array}$ \\
\hline
\end{tabular}

\begin{tabular}{|c|c|c|c|c|}
\hline No. & $\begin{array}{l}\text { Energy } \\
\left(\mathrm{cm}^{-1}\right)\end{array}$ & $\begin{array}{c}\lambda \\
(\mathrm{nm})\end{array}$ & $f^{[a]}$ & $\begin{array}{c}\text { Major } \\
\text { excitations }^{[\mathrm{b}]}\end{array}$ \\
\hline 48 & 49099 & 203.7 & 0.025 & $\begin{array}{l}\mathrm{H}-14 » \text { LUMO (37\%) } \\
\mathrm{H}-13 » \text { LUMO (29\%) }\end{array}$ \\
\hline 49 & 49328 & 202.7 & 0.045 & $\begin{array}{l}H-4 » L+4(27 \%) \\
H-3 » L+4(34 \%)\end{array}$ \\
\hline 50 & 49372 & 202.5 & 0.100 & $\begin{array}{l}H-4 » L+5(27 \%) \\
H-2 » L+6(14 \%)\end{array}$ \\
\hline
\end{tabular}

[a] Oscillator strength. [b] Contributions smaller than $10 \%$ are not included. $\mathrm{H}=\mathrm{HOMO}, \mathrm{L}=$ LUMO. Orbitals are numbered consecutively regardless of possible degeneracies. 
Table S14. Electronic transitions calculated for 9 using the TDA/PCM(DMSO)/B3LYP/6-31G(d,p) level of theory.

\begin{tabular}{|c|c|c|c|c|}
\hline No. & $\begin{array}{l}\text { Energy } \\
\left(\mathrm{cm}^{-1}\right)\end{array}$ & $\begin{array}{c}\lambda \\
(\mathrm{nm})\end{array}$ & $f^{[\mathrm{a}]}$ & $\begin{array}{c}\text { Major } \\
\text { excitations }^{[\mathrm{b}]}\end{array}$ \\
\hline 1 & 18343 & 545.2 & 0.586 & $\begin{array}{l}\text { HOMO»LUMO } \\
(95 \%)\end{array}$ \\
\hline 2 & 22063 & 453.2 & 0.025 & $\mathrm{H}-2 » L U M O(89 \%)$ \\
\hline 3 & 23885 & 418.7 & 0.367 & $\mathrm{H}-1 » L U M O(81 \%)$ \\
\hline 4 & 27599 & 362.3 & 0.003 & HOMO»L+1 (94\%) \\
\hline 5 & 29214 & 342.3 & 0.004 & $\begin{array}{l}\mathrm{H}-6 » \text { LUMO (11\%) } \\
\mathrm{H}-3 » \text { LUMO }(77 \%)\end{array}$ \\
\hline 6 & 30473 & 328.2 & 0.040 & $\begin{array}{l}\mathrm{H}-5 » L U M O(25 \%) \\
\mathrm{H}-4 » L U M O(13 \%) \\
\text { HOMO»L+2 (34\%) } \\
\text { HOMO»L+3 (11\%) }\end{array}$ \\
\hline 7 & 30795 & 324.7 & 0.012 & $\begin{array}{l}\mathrm{H}-6 » \text { LUMO (61\%) } \\
\mathrm{H}-5 » \text { LUMO (11\%) }\end{array}$ \\
\hline 8 & 31169 & 320.8 & 0.170 & $\begin{array}{l}\mathrm{H}-5 » L U M O(13 \%) \\
\mathrm{H}-4 » L U M O(15 \%) \\
\text { HOMO»L+2 (47\%) } \\
\text { HOMO»L+3 (12\%) }\end{array}$ \\
\hline 9 & 32614 & 306.6 & 0.014 & $\begin{array}{l}\mathrm{H}-6 » \text { LUMO (18\%) } \\
\mathrm{H}-4 » L U M O(53 \%)\end{array}$ \\
\hline 10 & 33738 & 296.4 & 0.022 & $\begin{array}{l}\mathrm{H}-8 » L U M O(12 \%) \\
\mathrm{H}-7 » L U M O(26 \%) \\
\mathrm{H}-1 » L+1(49 \%)\end{array}$ \\
\hline 11 & 33951 & 294.5 & 0.162 & $\begin{array}{l}\mathrm{H}-8 » L U M O(11 \%) \\
\mathrm{H}-7 » L U M O(13 \%) \\
\mathrm{H}-1 » L+1(26 \%) \\
\text { HOMO»L+4 (21\%) }\end{array}$ \\
\hline 12 & 34326 & 291.3 & 0.080 & $\begin{array}{l}\mathrm{H}-8 » L U M O(13 \%) \\
\mathrm{H}-5 » L U M O(15 \%) \\
\text { HOMO»L+3 (49\%) }\end{array}$ \\
\hline 13 & 34706 & 288.1 & 0.024 & $\begin{array}{l}\mathrm{H}-7 » L U M O(12 \%) \\
\mathrm{H}-1 » L+1(13 \%) \\
\text { HOMO»L+4 (43\%) }\end{array}$ \\
\hline 14 & 35419 & 282.3 & 0.002 & $\mathrm{H}-1 » \mathrm{~L}+2$ (77\%) \\
\hline 15 & 36844 & 271.4 & 0.615 & $\begin{array}{l}\mathrm{H}-8 » L U M O(18 \%) \\
\mathrm{H}-7 » L U M O(10 \%) \\
\mathrm{H}-2 » \mathrm{~L}+1(35 \%) \\
\mathrm{H}-1 » \mathrm{~L}+2(10 \%)\end{array}$ \\
\hline 16 & 37230 & 268.6 & 0.125 & $\begin{array}{l}H-2 » L+1(12 \%) \\
H-2 » L+2(75 \%)\end{array}$ \\
\hline 17 & 37426 & 267.2 & 0.014 & $\begin{array}{l}\text { H-8»LUMO (11\%) } \\
\text { HOMO»L+5 (57\%) }\end{array}$ \\
\hline 18 & 38174 & 262.0 & 0.301 & $\begin{array}{l}\mathrm{H}-8 » \mathrm{LUMO}(16 \%) \\
\mathrm{H}-7 » \mathrm{LUMO}(11 \%) \\
\mathrm{H}-2 » \mathrm{~L}+1(31 \%) \\
\mathrm{H}-2 » \mathrm{~L}+3(14 \%) \\
\text { HOMO»L+5 (11\%) }\end{array}$ \\
\hline 19 & 38974 & 256.6 & 0.106 & $\begin{array}{l}\mathrm{H}-9 » L U M O(18 \%) \\
\mathrm{H}-1 » \mathrm{~L}+3(51 \%)\end{array}$ \\
\hline 20 & 39662 & 252.1 & 0.162 & $\begin{array}{l}H-2 » L+3(50 \%) \\
H-1 » L+4(16 \%)\end{array}$ \\
\hline 21 & 39833 & 251.0 & 0.100 & $\begin{array}{l}H-2 » L+3(13 \%) \\
H-1 » L+4(54 \%)\end{array}$ \\
\hline 22 & 40363 & 247.7 & 0.087 & H-9»LUMO (56\%) \\
\hline 23 & 41001 & 243.9 & 0.002 & $\begin{array}{l}H-3 » L+1(66 \%) \\
H-1 » L+4(10 \%)\end{array}$ \\
\hline
\end{tabular}

\begin{tabular}{|c|c|c|c|c|}
\hline No. & $\begin{array}{l}\text { Energy } \\
\left(\mathrm{cm}^{-1}\right)\end{array}$ & $\begin{array}{c}\lambda \\
(\mathrm{nm})\end{array}$ & $f^{[\mathrm{a}]}$ & $\begin{array}{c}\text { Major } \\
\text { excitations }^{[\mathrm{b}]}\end{array}$ \\
\hline 24 & 42378 & 236.0 & 0.001 & $\begin{array}{l}H-6 » L+1(42 \%) \\
H-4 » L+1(11 \%) \\
H O M O » L+6(14 \%)\end{array}$ \\
\hline 25 & 42425 & 235.7 & 0.054 & $\begin{array}{l}H-4 » L+1(10 \%) \\
H-2 » L+4(23 \%) \\
H O M O » L+6(38 \%)\end{array}$ \\
\hline 26 & 43025 & 232.4 & 0.008 & $\begin{array}{l}\mathrm{H}-1 » \mathrm{~L}+5(39 \%) \\
\mathrm{HOMO} » \mathrm{~L}+6(11 \%)\end{array}$ \\
\hline 27 & 43150 & 231.7 & 0.019 & $\begin{array}{l}H-2 » L+4(58 \%) \\
H-1 » L+5(13 \%)\end{array}$ \\
\hline 28 & 43349 & 230.7 & 0.060 & $\begin{array}{l}H-6 » L+1(23 \%) \\
H-6 » L+2(11 \%) \\
H-4 » L+1(36 \%)\end{array}$ \\
\hline 29 & 43516 & 229.8 & 0.024 & $\begin{array}{l}H-6 » L+2(40 \%) \\
H-4 » L+1(19 \%) \\
H-4 » L+2(19 \%)\end{array}$ \\
\hline 30 & 44288 & 225.8 & 0.160 & $\begin{array}{l}H-5 » L+1(52 \%) \\
H-1 » L+5(14 \%)\end{array}$ \\
\hline 31 & 44416 & 225.1 & 0.036 & $\begin{array}{l}H-6 » L+2(12 \%) \\
H-4 » L+2(54 \%)\end{array}$ \\
\hline 32 & 44811 & 223.2 & 0.001 & $\begin{array}{l}H-5 » L+2(19 \%) \\
H-2 » L+5(56 \%)\end{array}$ \\
\hline 33 & 45418 & 220.2 & 0.022 & $\begin{array}{l}H-10 » L U M O(10 \%) \\
H-8 » L+1(12 \%) \\
H-7 » L+1(30 \%) \\
H-5 » L+2(16 \%) \\
H-2 » L+5(13 \%)\end{array}$ \\
\hline 34 & 45515 & 219.7 & 0.035 & $\begin{array}{l}H-8 » L+1(10 \%) \\
H-7 » L+1(16 \%) \\
H-6 » L+2(10 \%) \\
H-5 » L+2(21 \%) \\
H-4 » L+3(13 \%) \\
H-2 » L+5(10 \%)\end{array}$ \\
\hline 35 & 45755 & 218.6 & 0.003 & $\begin{array}{l}\text { H-12»LUMO (74\%) } \\
\text { H-11»LUMO (12\%) }\end{array}$ \\
\hline 36 & 46448 & 215.3 & 0.074 & $\begin{array}{l}\mathrm{H}-10 » \mathrm{LUMO}(35 \%) \\
\mathrm{H}-8 » \mathrm{~L}+1(11 \%)\end{array}$ \\
\hline 37 & 46649 & 214.4 & 0.298 & $\begin{array}{l}\mathrm{H}-10 » L \mathrm{~L} M O(18 \%) \\
\mathrm{H}-3 » \mathrm{~L}+2(21 \%) \\
\mathrm{H}-3 » \mathrm{~L}+3(10 \%)\end{array}$ \\
\hline 38 & 46963 & 212.9 & 0.044 & $H-3 » L+3(82 \%)$ \\
\hline 39 & 47431 & 210.8 & 0.184 & $\begin{array}{l}H-8 » L+2(11 \%) \\
H-7 » L+2(48 \%) \\
H-3 » L+2(10 \%)\end{array}$ \\
\hline 40 & 48285 & 207.1 & 0.006 & $\begin{array}{l}\mathrm{H}-14 » \text { LUMO (18\%) } \\
\mathrm{H}-13 » \mathrm{LUMO}(14 \%) \\
\mathrm{H}-11 » \mathrm{LUMO}(24 \%) \\
\mathrm{H}-1 » \mathrm{~L}+6(15 \%)\end{array}$ \\
\hline 41 & 48475 & 206.3 & 0.007 & $\begin{array}{l}H-14 » L U M O(13 \%) \\
H-4 » L+3(10 \%) \\
H-1 » L+6(35 \%)\end{array}$ \\
\hline 42 & 48615 & 205.7 & 0.088 & $\begin{array}{l}H-6 » L+4(19 \%) \\
H-4 » L+4(18 \%) \\
H O M O » L+7(20 \%)\end{array}$ \\
\hline
\end{tabular}




\begin{tabular}{|c|c|c|c|c|}
\hline No. & $\begin{array}{l}\text { Energy } \\
\left(\mathrm{cm}^{-1}\right)\end{array}$ & $\begin{array}{c}\lambda \\
(\mathrm{nm})\end{array}$ & $f^{[a]}$ & $\begin{array}{c}\text { Major } \\
\text { excitations }^{[\mathrm{b}]}\end{array}$ \\
\hline 43 & 48642 & 205.6 & 0.180 & $\begin{array}{l}\mathrm{H}-14 » \mathrm{LUMO}(13 \%) \\
\mathrm{H}-6 » \mathrm{~L}+3(17 \%) \\
\mathrm{H}-4 » \mathrm{~L}+3(17 \%) \\
\mathrm{H}-1 » \mathrm{~L}+6(10 \%)\end{array}$ \\
\hline 44 & 48809 & 204.9 & 0.025 & $\begin{array}{l}\mathrm{H}-8 » \mathrm{~L}+2(20 \%) \\
\mathrm{H}-6 » \mathrm{~L}+4(12 \%) \\
\mathrm{H}-4 » \mathrm{~L}+4(12 \%) \\
\mathrm{H}-3 » \mathrm{~L}+4(10 \%) \\
\mathrm{HOMO} » \mathrm{~L}+7(20 \%)\end{array}$ \\
\hline 45 & 48969 & 204.2 & 0.245 & $\begin{array}{l}\mathrm{H}-14 » \mathrm{LUMO}(11 \%) \\
\mathrm{H}-8 » \mathrm{~L}+1(28 \%) \\
\mathrm{H}-7 » \mathrm{~L}+1(21 \%)\end{array}$ \\
\hline 46 & 49288 & 202.9 & 0.023 & $\begin{array}{l}H-6 » L+3(30 \%) \\
H-4 » L+4(12 \%)\end{array}$ \\
\hline 47 & 49491 & 202.1 & 0.031 & $\begin{array}{l}H-6 » L+3(16 \%) \\
H-6 » L+4(34 \%) \\
H-3 » L+5(12 \%)\end{array}$ \\
\hline 48 & 49710 & 201.2 & 0.132 & $\begin{array}{l}\mathrm{H}-14 » \mathrm{LUMO}(16 \%) \\
\mathrm{H}-11 » \mathrm{LUMO}(11 \%) \\
\mathrm{H}-6 » \mathrm{~L}+3(15 \%) \\
\mathrm{H}-5 » \mathrm{~L}+4(10 \%)\end{array}$ \\
\hline 49 & 49891 & 200.4 & 0.035 & $\begin{array}{l}\mathrm{H}-13 » \mathrm{LUMO}(23 \%) \\
\mathrm{H}-9 » \mathrm{~L}+1(10 \%) \\
\mathrm{H}-4 » \mathrm{~L}+4(10 \%) \\
\mathrm{H}-3 » \mathrm{~L}+5(11 \%)\end{array}$ \\
\hline 50 & 50199 & 199.2 & 0.031 & $\begin{array}{l}\mathrm{H}-13 » \mathrm{LUMO}(19 \%) \\
\mathrm{H}-9 » \mathrm{~L}+1(27 \%) \\
\mathrm{H}-3 » \mathrm{~L}+5(11 \%)\end{array}$ \\
\hline
\end{tabular}

[a] Oscillator strength. [b] Contributions smaller than $10 \%$ are not included. $\mathrm{H}=$ HOMO, L = LUMO. Orbitals are numbered consecutively regardless of possible degeneracies. 
Table S15. Nucleus-independent chemical shift (NICS(1)) values for $[\mathbf{1 1} '-Z n]^{n}$ (GIAO/B3LYP/6$31 G(d, p))$. Nuclear shieldings were evaluated $1 \AA$ above ring centers, on the side of the molecule facing the viewer. The values were averaged assuming $D_{2 d}$ symmetry in all cases.

\begin{tabular}{|c|c|c|c|c|c|c|c|}
\hline charge $n=$ & 4 & 2 & 0 & -2 & -4 & -6 & -8 \\
\hline \multicolumn{8}{|l|}{ Ring $^{[a]}$} \\
\hline A & -1.56 & 18.16 & -10.74 & 0.08 & -3.31 & -1.44 & -6.69 \\
\hline B & 2.26 & 6.62 & -8.02 & -0.64 & -2.37 & 0.33 & -5.00 \\
\hline B' $^{\prime}$ & 1.73 & -4.27 & -2.92 & -0.45 & -0.56 & 1.05 & -1.01 \\
\hline C & -1.57 & 1.08 & 1.76 & -0.95 & -3.67 & -6.86 & -13.83 \\
\hline $\mathbf{C}^{\prime}$ & -0.94 & -0.72 & 4.98 & -0.54 & -2.17 & -5.67 & -11.80 \\
\hline D & -6.20 & -9.49 & -8.94 & -8.59 & -6.94 & -5.90 & -5.67 \\
\hline $\mathbf{D}^{\prime}$ & -5.53 & -9.87 & -8.12 & -8.13 & -6.50 & -5.67 & -5.08 \\
\hline E & -0.32 & 0.19 & 0.26 & -1.24 & -3.11 & -4.90 & -7.38 \\
\hline$E^{\prime}$ & 0.07 & 0.22 & 0.50 & -0.90 & -2.86 & -4.71 & -6.83 \\
\hline
\end{tabular}

[a] Ring labeling:

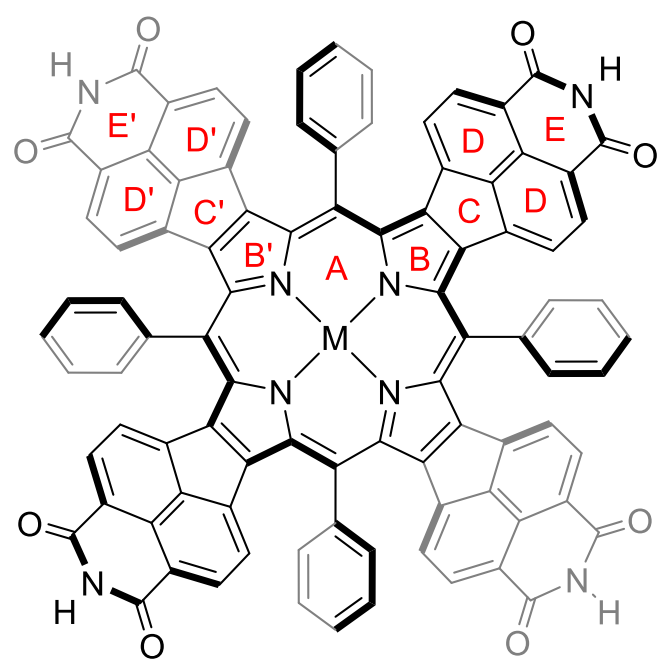


Table S16. CIE coordinates for pyrroles 1-9.

\begin{tabular}{clll}
\hline Compound & Solvent & $\boldsymbol{x}$ & $\boldsymbol{y}$ \\
\hline $\mathbf{1}$ & DMSO & 0.16 & 0.16 \\
$\mathbf{2}$ & DMSO & 0.19 & 0.30 \\
$\mathbf{3}$ & DMSO & 0.33 & 0.52 \\
$\mathbf{4}$ & DMSO & 0.54 & 0.46 \\
& toluene & 0.31 & 0.55 \\
& acetone & 0.48 & 0.51 \\
& EtOAC & 0.42 & 0.54 \\
& THF & 0.43 & 0.54 \\
& MeOH & 0.57 & 0.43 \\
$\mathbf{5}$ & DMSO & 0.56 & 0.44 \\
$\mathbf{7}$ & DMSO & 0.61 & 0.38 \\
$\mathbf{8}$ & DMSO & 0.60 & 0.40 \\
$\mathbf{9}$ & DMSO & 0.52 & 0.40 \\
\hline
\end{tabular}


NMR Spectra 


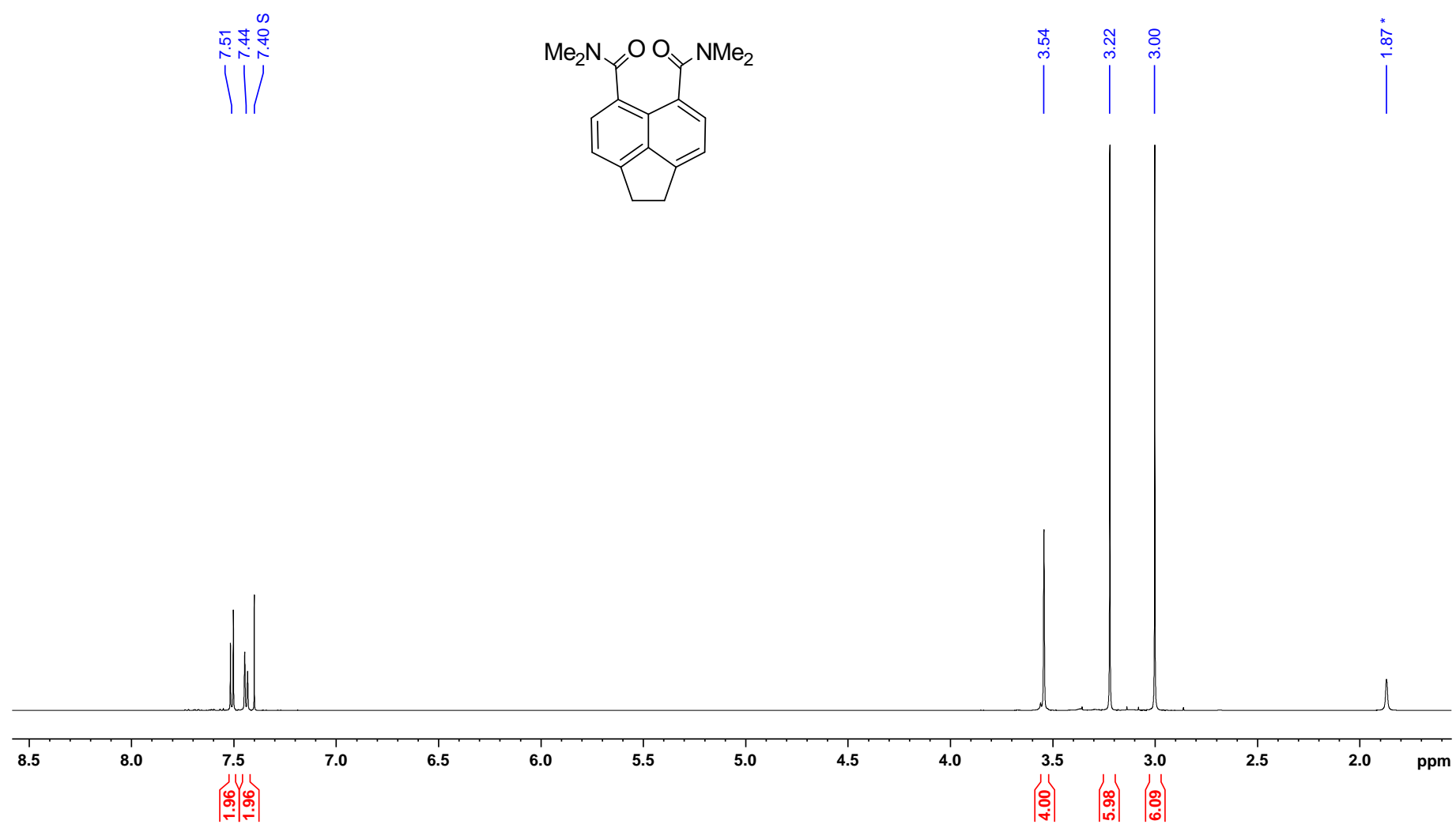

Figure S39. ${ }^{1} \mathrm{H}$ NMR spectrum of $\mathbf{S 2}(500 \mathrm{MHz}$, chloroform- $d, 300 \mathrm{~K})$.

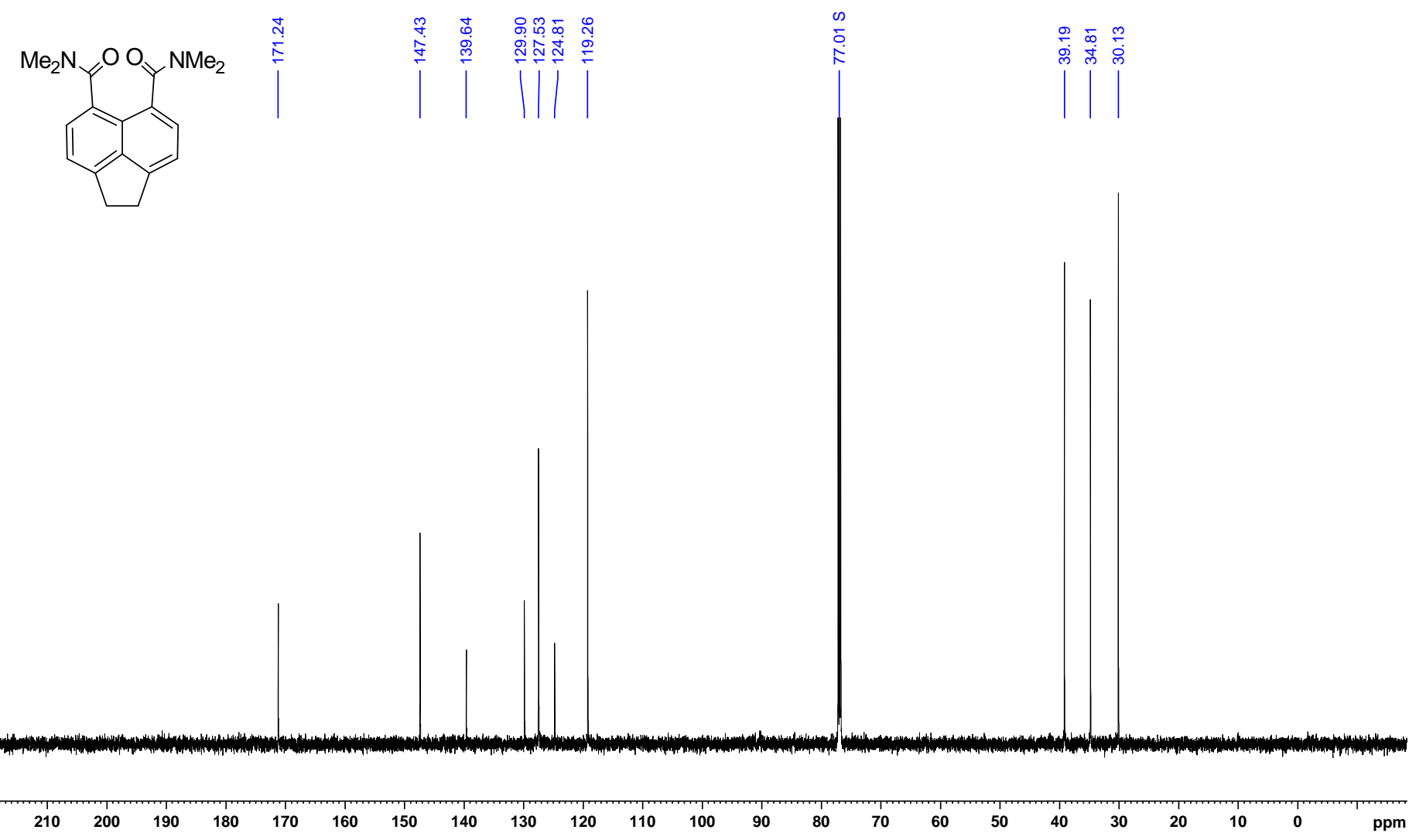

Figure S40. ${ }^{13} \mathrm{C}$ NMR spectrum of $\mathbf{S 2}(151 \mathrm{MHz}$, chloroform- $d, 300 \mathrm{~K})$. 

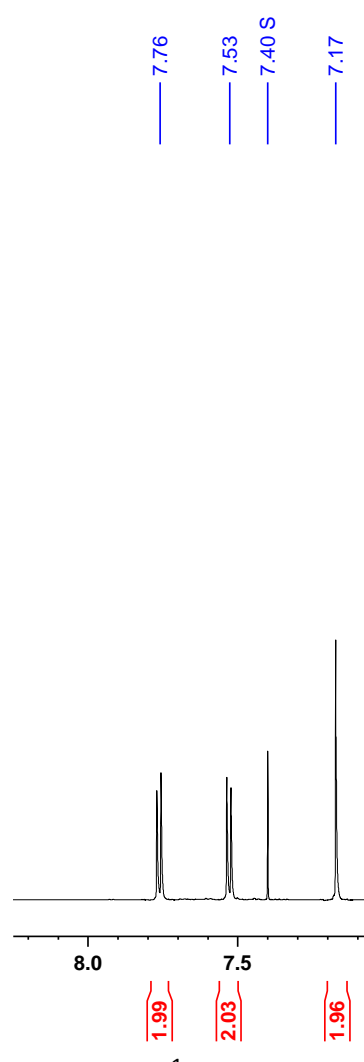

Figure S41. ${ }^{1} \mathrm{H}$ NMR spectrum of $\mathbf{S 3}(500 \mathrm{MHz}$, chloroform- $d, 300 \mathrm{~K})$.
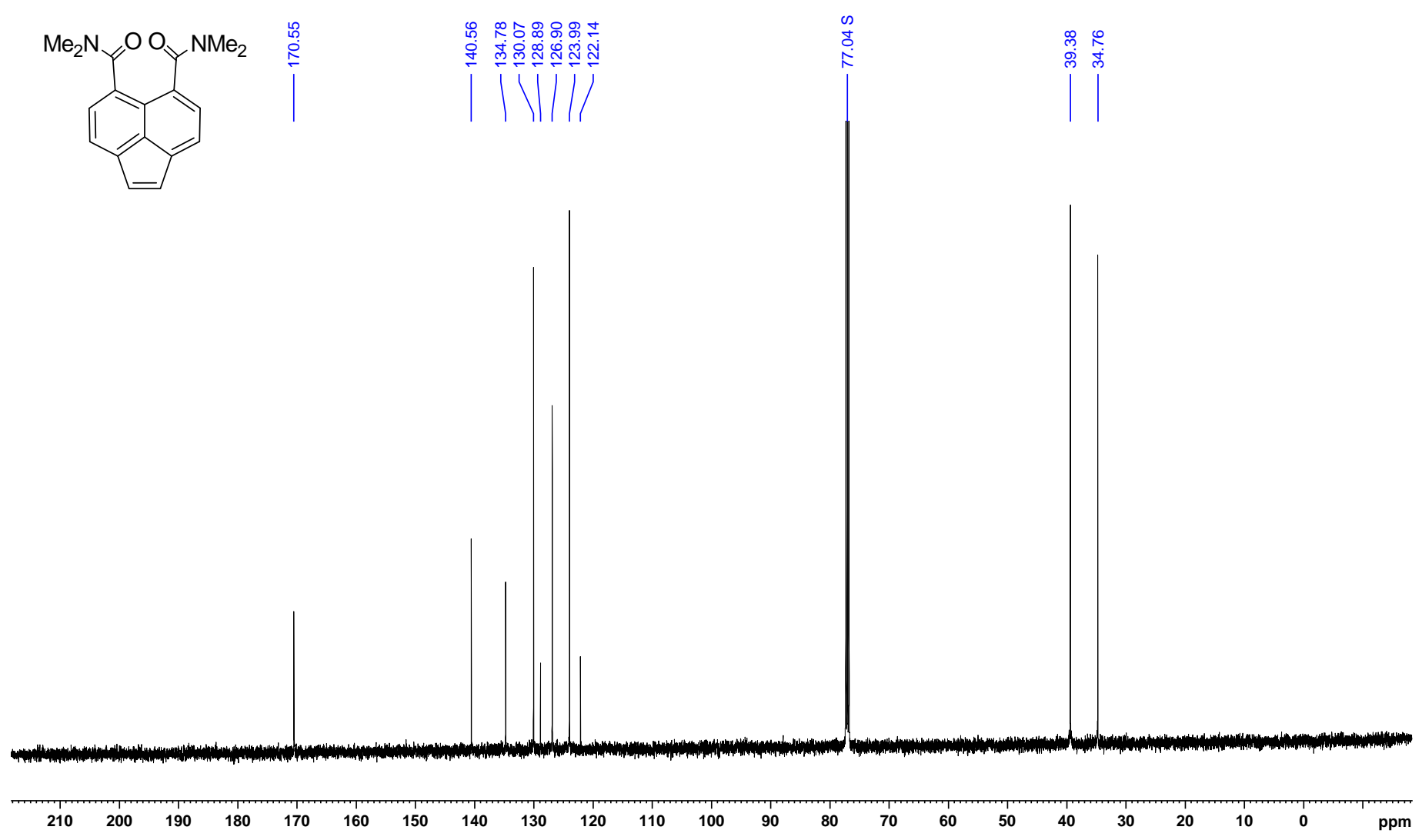

Figure $\mathbf{S 4 2 .}{ }^{13} \mathrm{C}$ NMR spectrum of $\mathbf{S 3}$ (125 MHz, chloroformed, $300 \mathrm{~K}$ ).

S68 


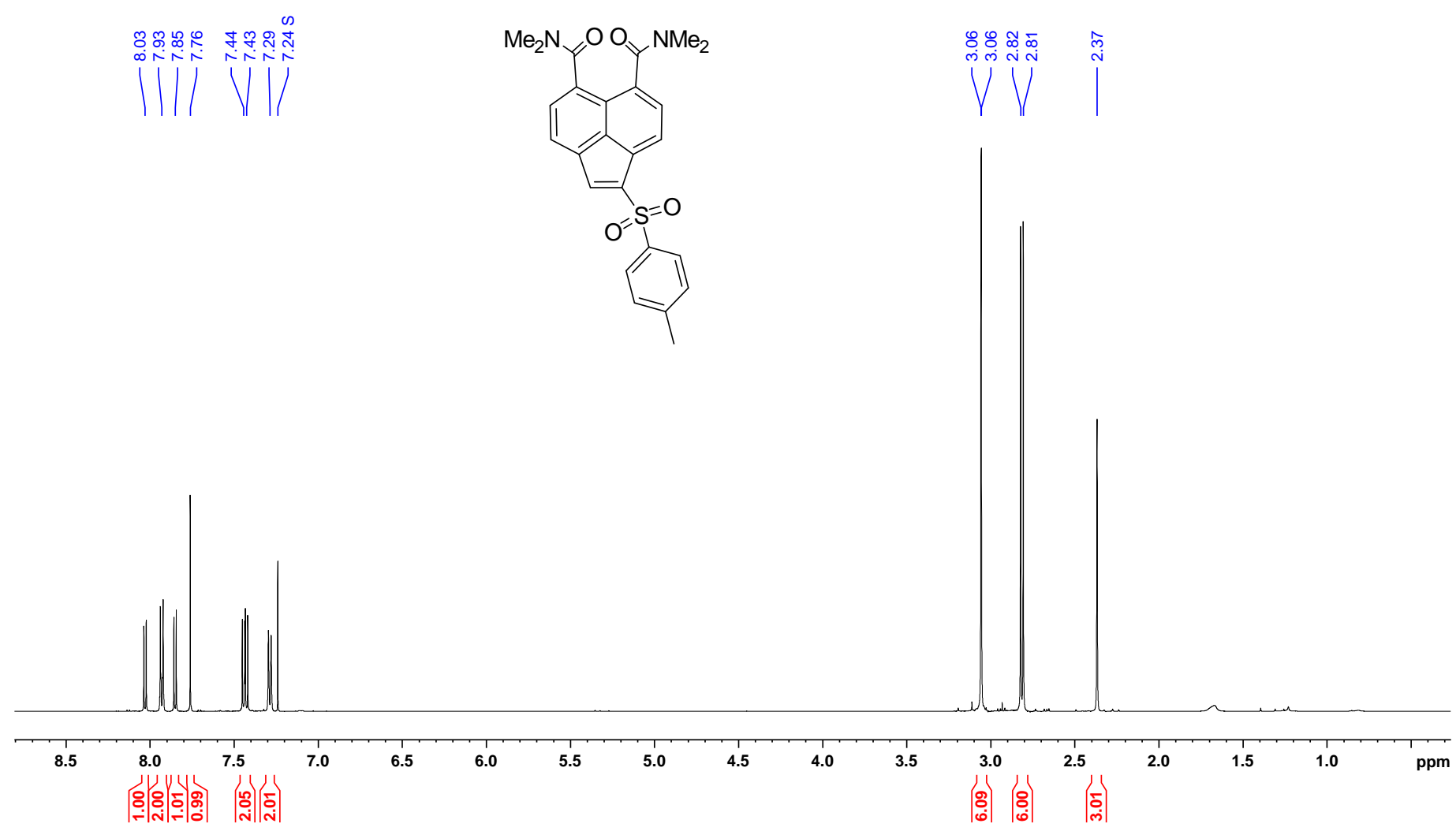

Figure S43. ${ }^{1} \mathrm{H}$ NMR spectrum of $\mathbf{S 4}(500 \mathrm{MHz}$, chloroform- $d, 300 \mathrm{~K})$.

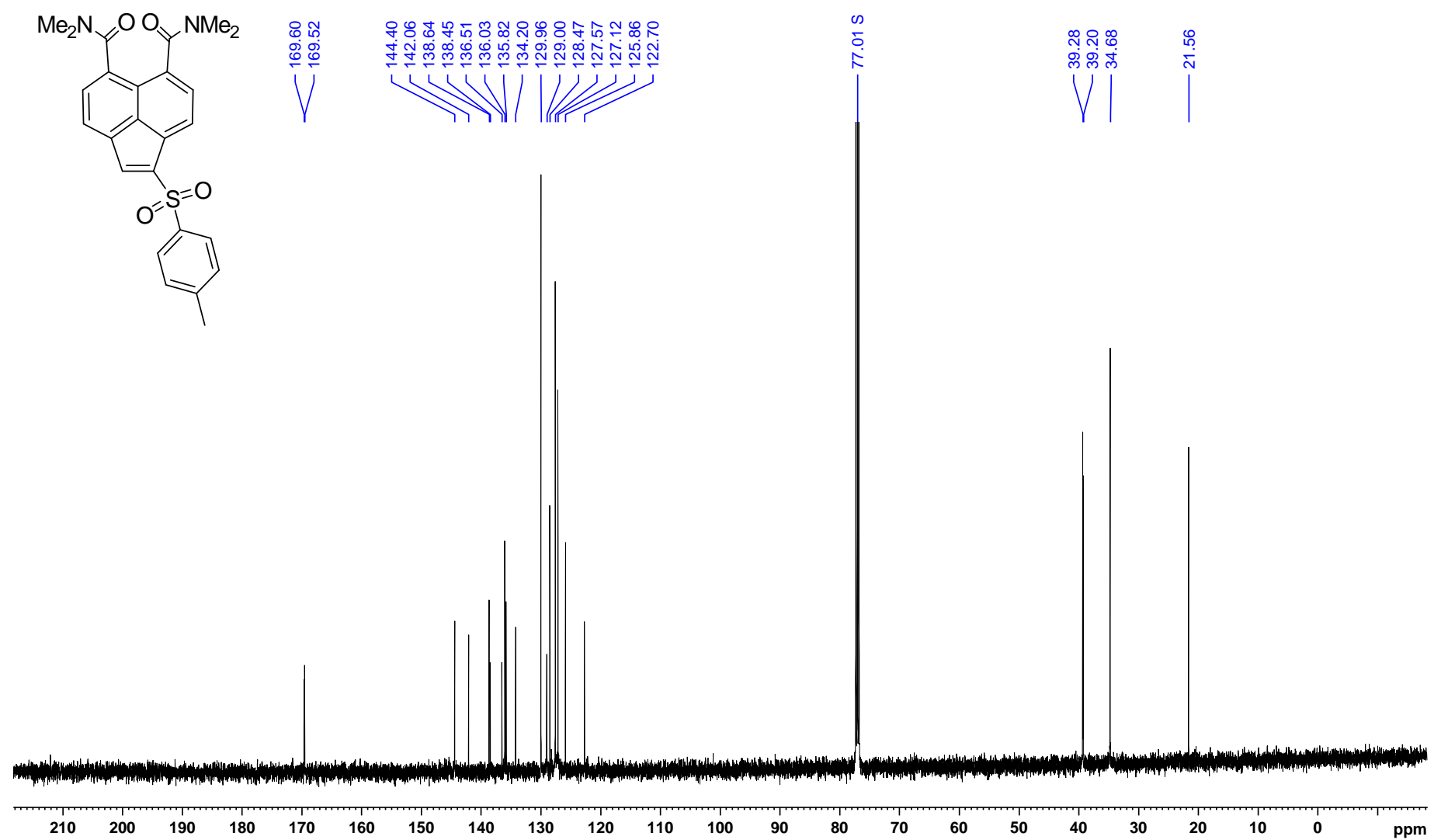

Figure S44. ${ }^{13} \mathrm{C}$ NMR spectrum of $\mathbf{S 4}(125 \mathrm{MHz}$, chloroform- $d, 300 \mathrm{~K})$. 


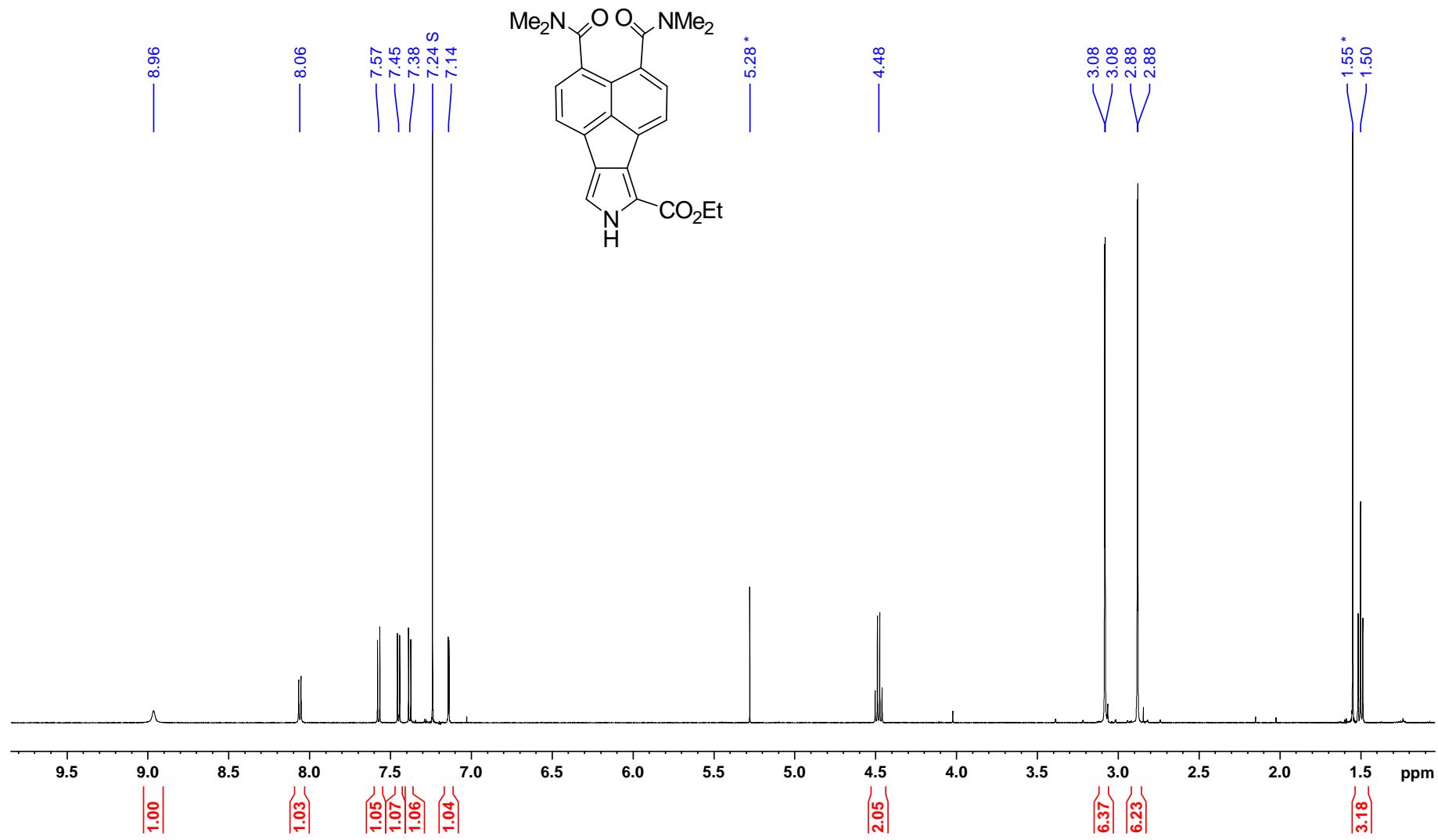

Figure S45. ${ }^{1} \mathrm{H}$ NMR spectrum of $\mathbf{S 5}(500 \mathrm{MHz}$, chloroform- $d, 300 \mathrm{~K})$.

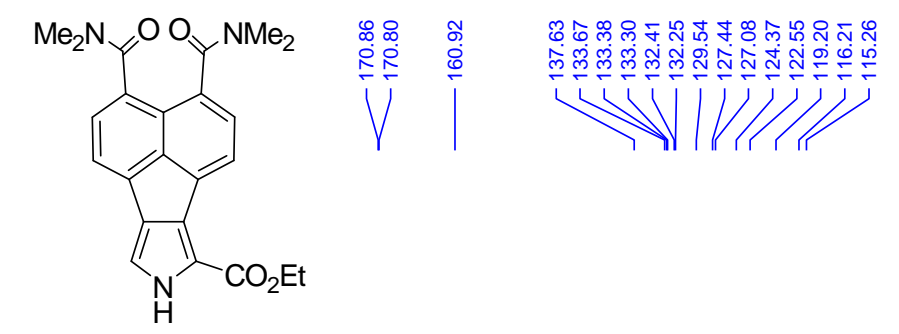

$\begin{array}{llllllllllllll}210 & 200 & 190 & 180 & 170 & 160 & 150 & 140 & 130 & 120 & 110 & 100 & 90\end{array}$

Figure S46. ${ }^{13} \mathrm{C}$ NMR spectrum of $\mathbf{S 5}$ (151 MHz, chloroform- $d, 300 \mathrm{~K}$ ). 

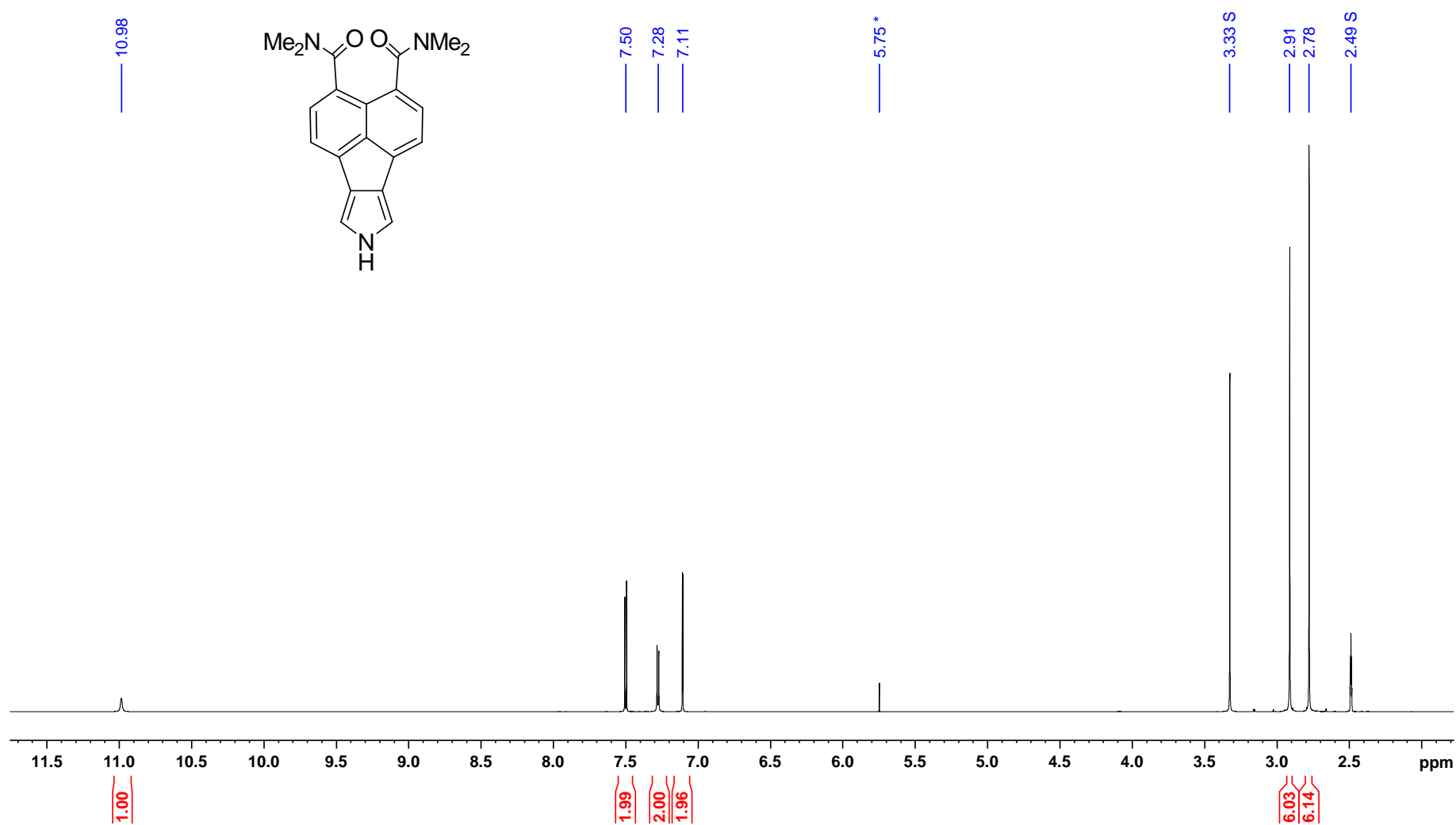

Figure S47. ${ }^{1} \mathrm{H}$ NMR spectrum of $2(600 \mathrm{MHz}$, DMSO-d6, $300 \mathrm{~K})$.
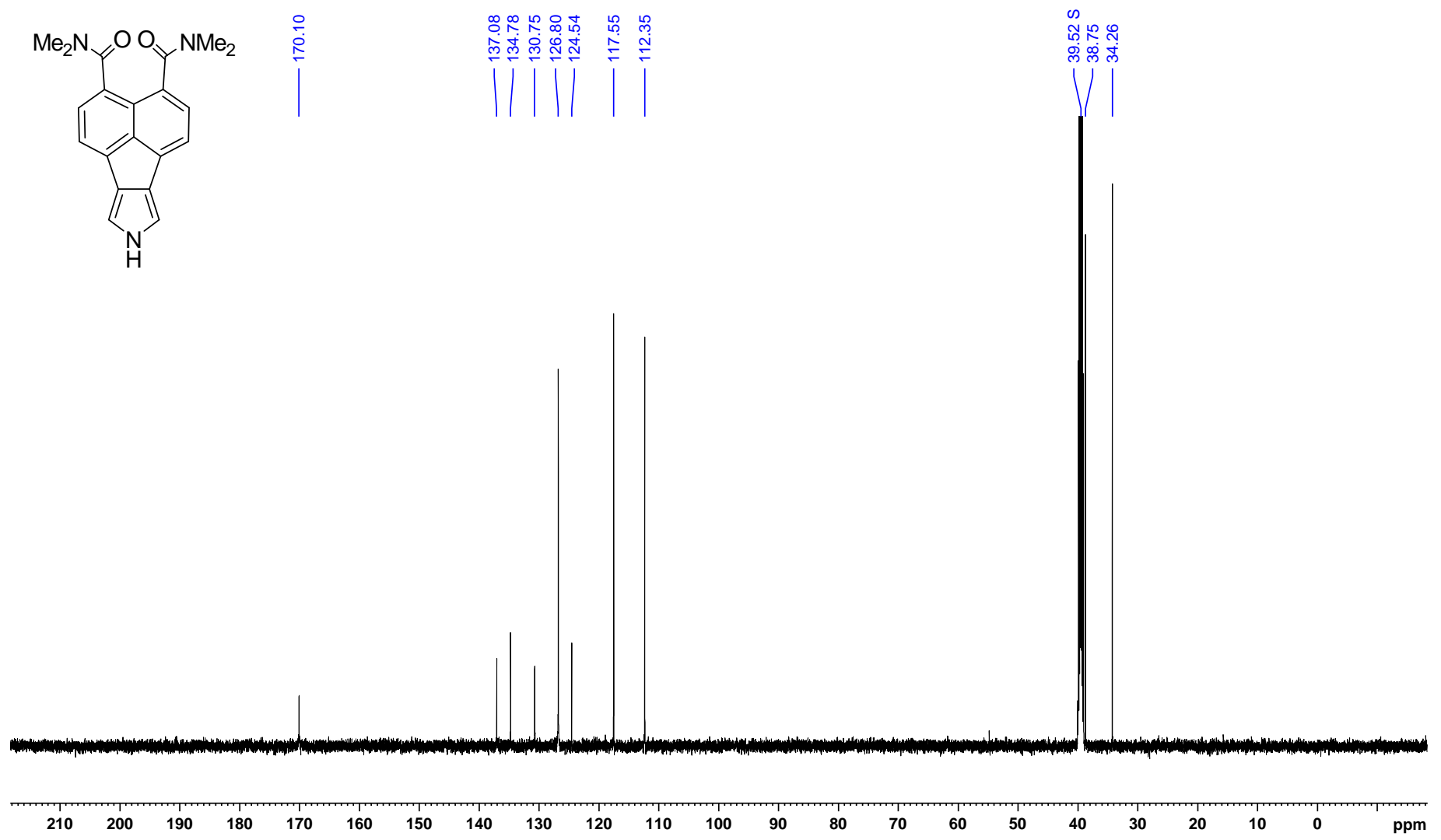

Figure S48. ${ }^{13} \mathrm{C}$ NMR spectrum of 2 (151 MHz, DMSO- $\left.d 6,300 \mathrm{~K}\right)$. 


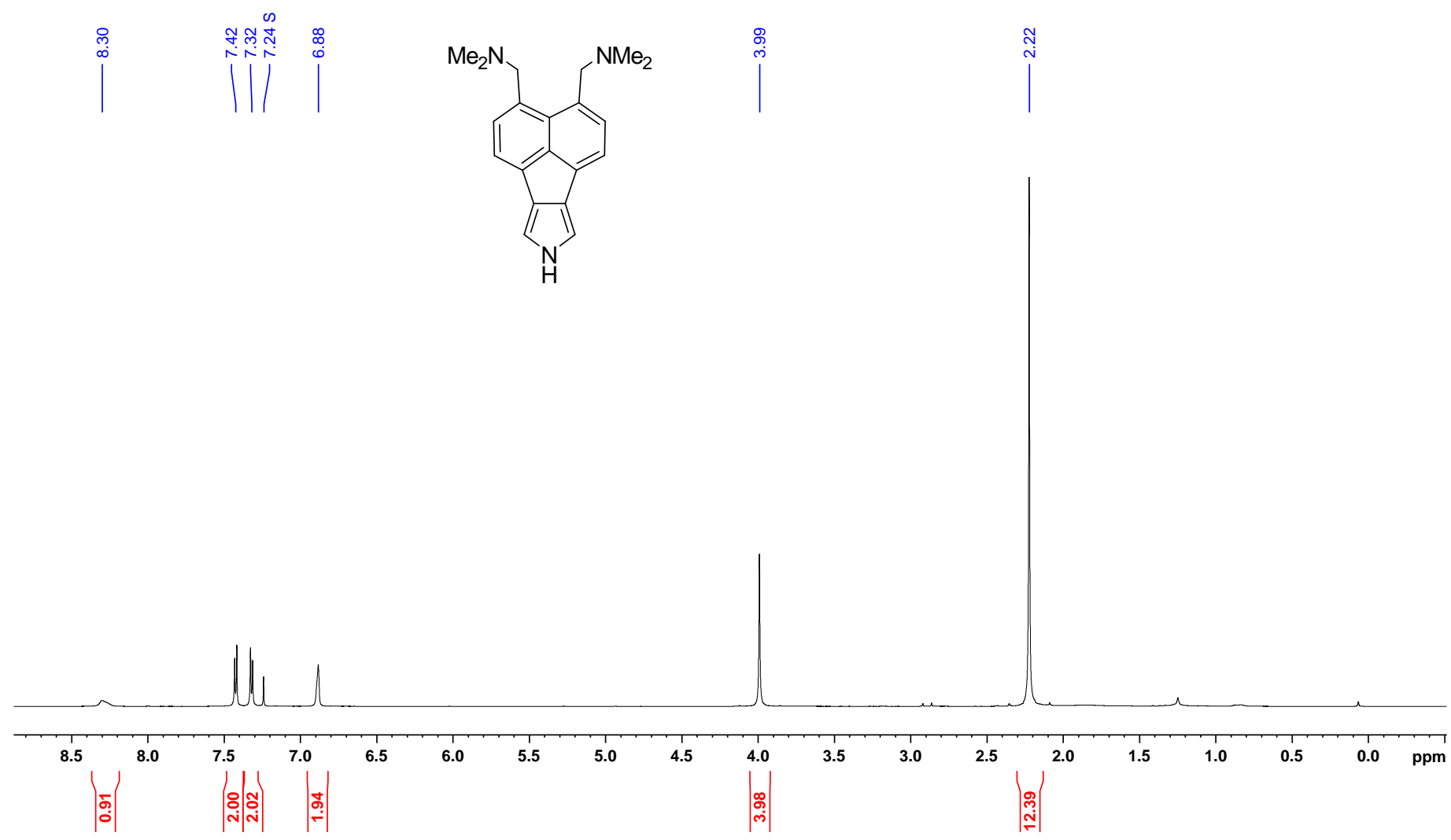

Figure S49. ${ }^{1} \mathrm{H}$ NMR spectrum of 1 (500 MHz, chloroform- $d$, $\left.300 \mathrm{~K}\right)$.

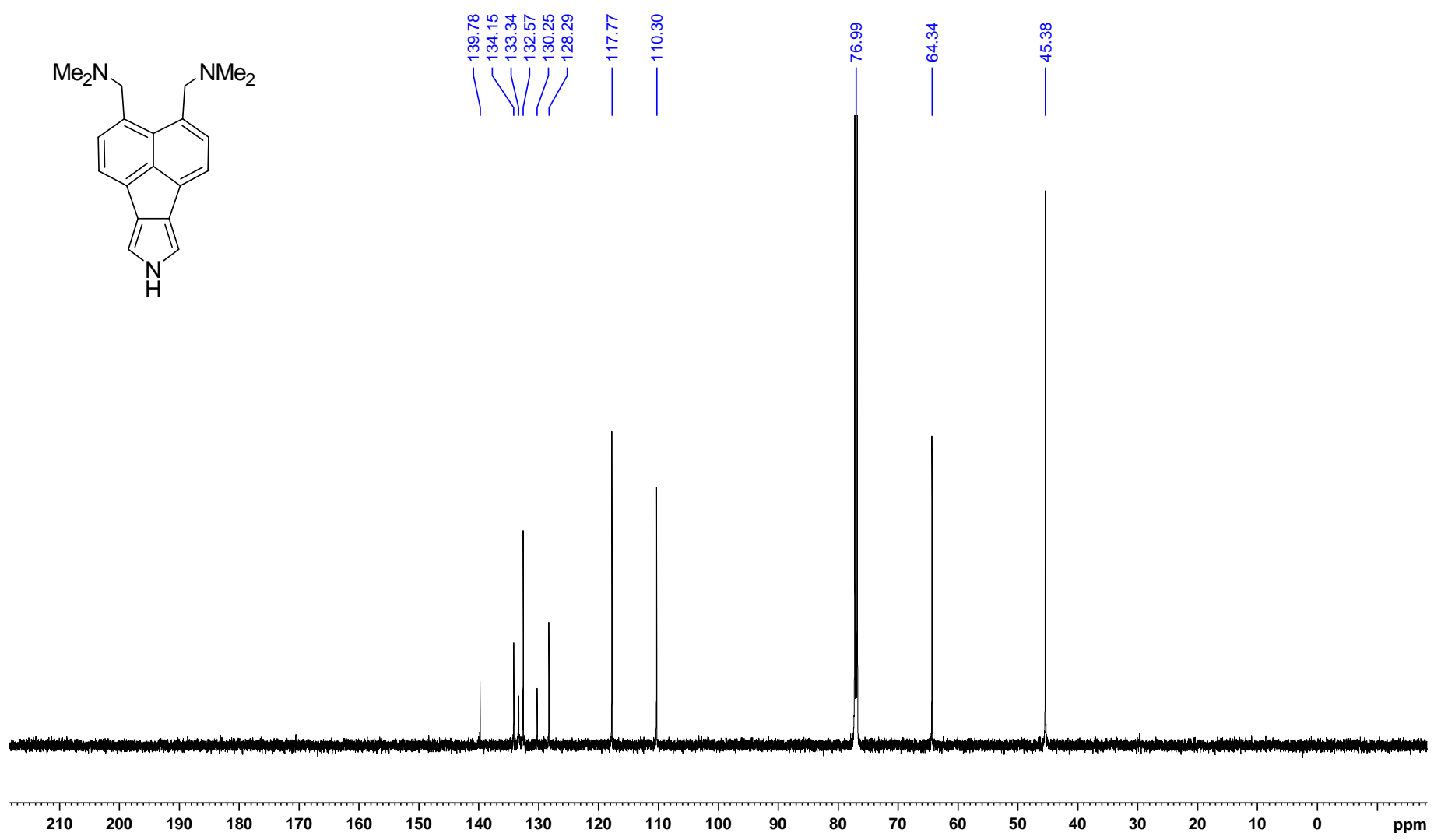

Figure S50. ${ }^{13} \mathrm{C}$ NMR spectrum of 1 (151 MHz, chloroform-d, $\left.300 \mathrm{~K}\right)$. 


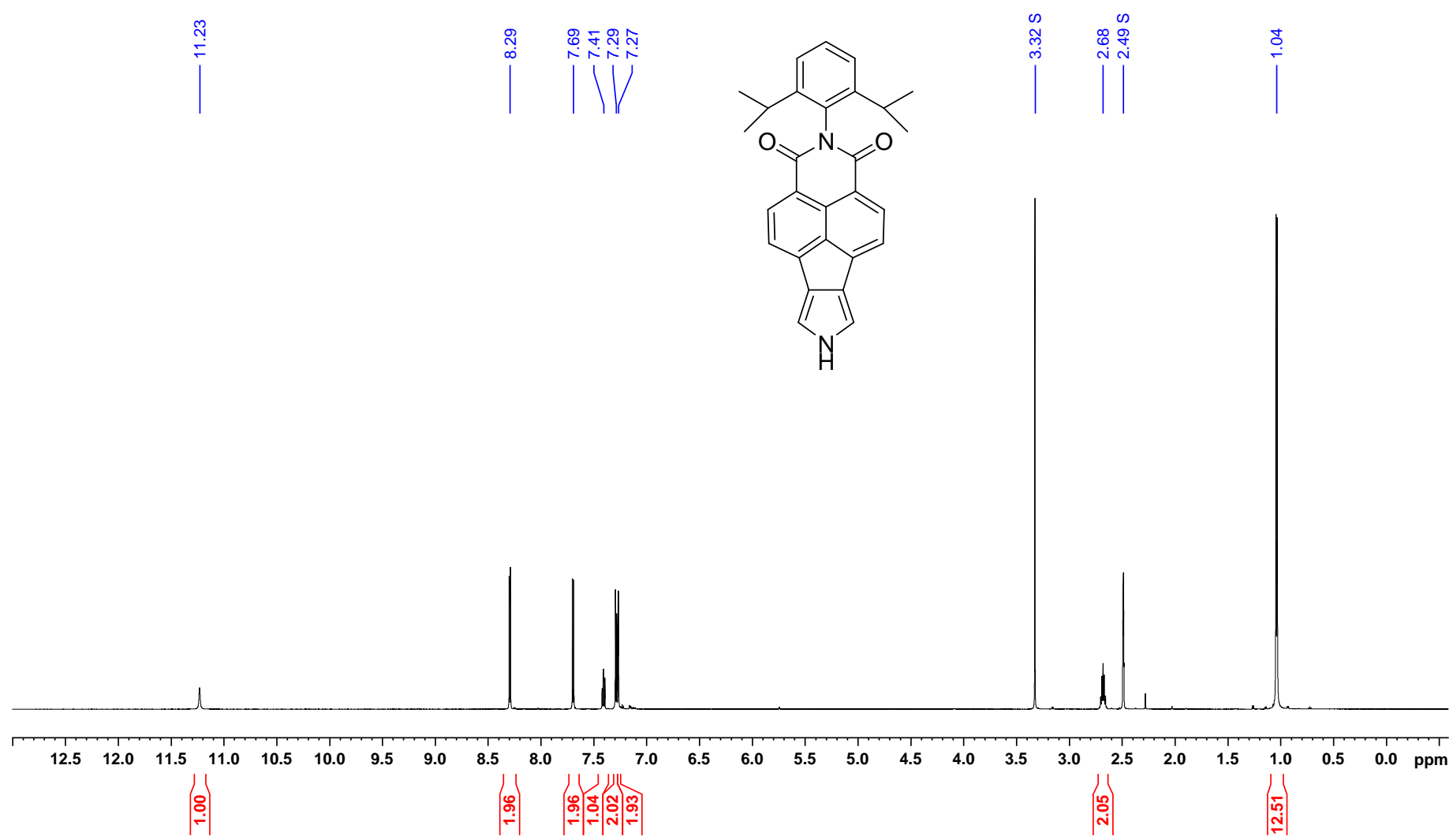

Figure S51. ${ }^{1} \mathrm{H}$ NMR spectrum of 4 (600 MHz, DMSO-d6, $\left.300 \mathrm{~K}\right)$.
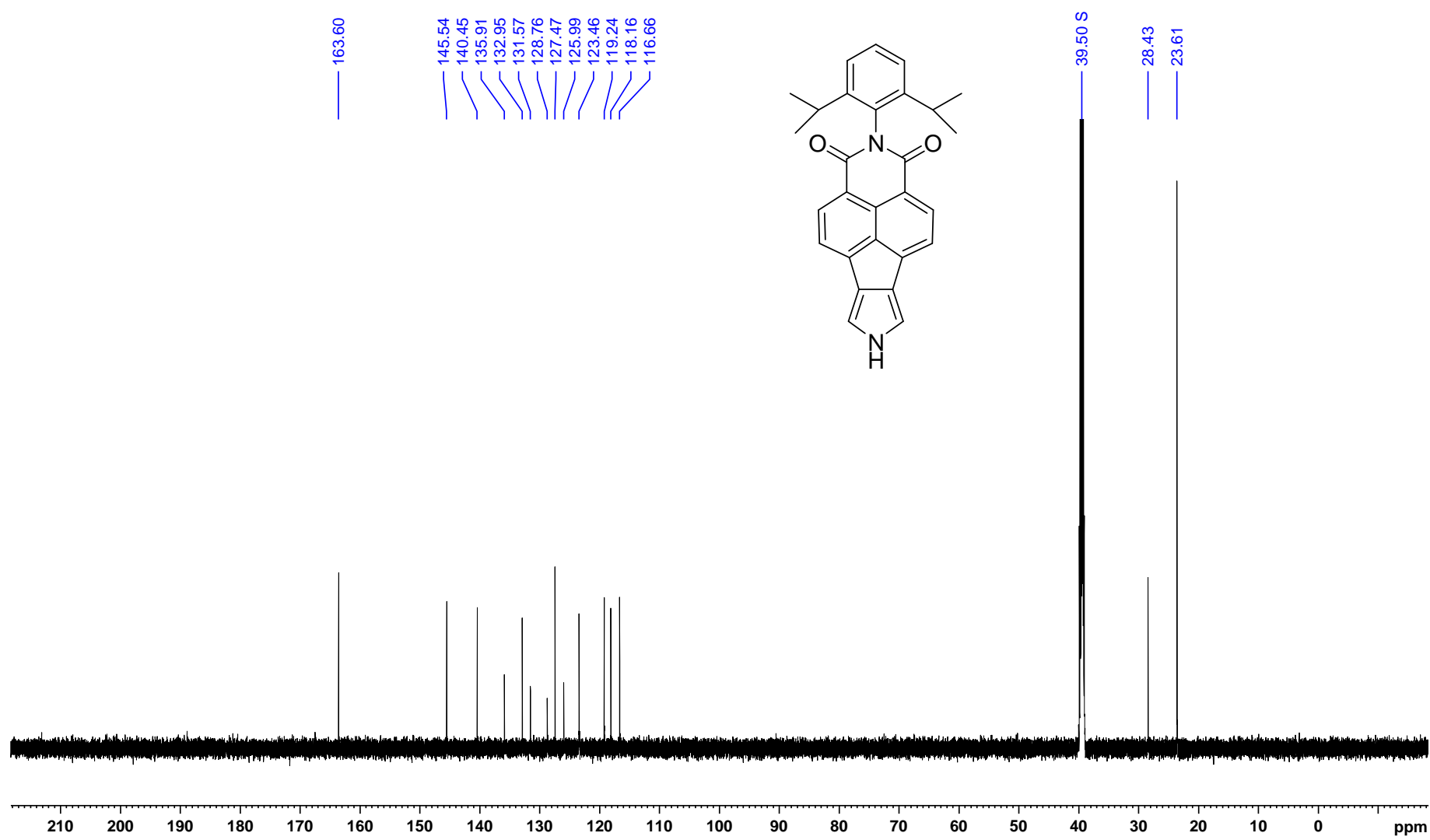

Figure S52. ${ }^{13} \mathrm{C}$ NMR spectrum of 4 (151 MHz, DMSO-d6, $300 \mathrm{~K}$ ). 


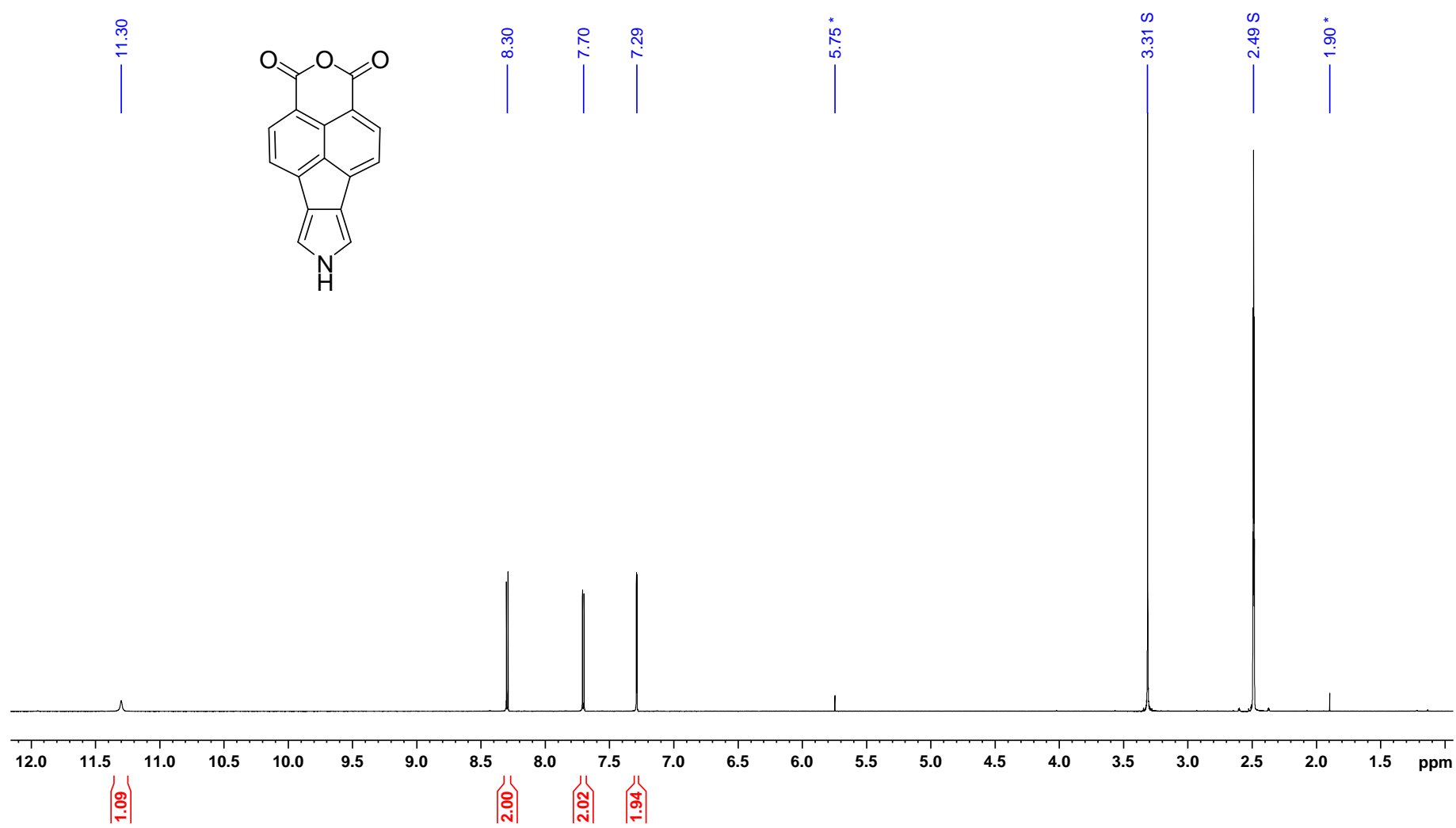

Figure S53. ${ }^{1} \mathrm{H}$ NMR spectrum of $5(600 \mathrm{MHz}$, DMSO-d6, $300 \mathrm{~K})$.
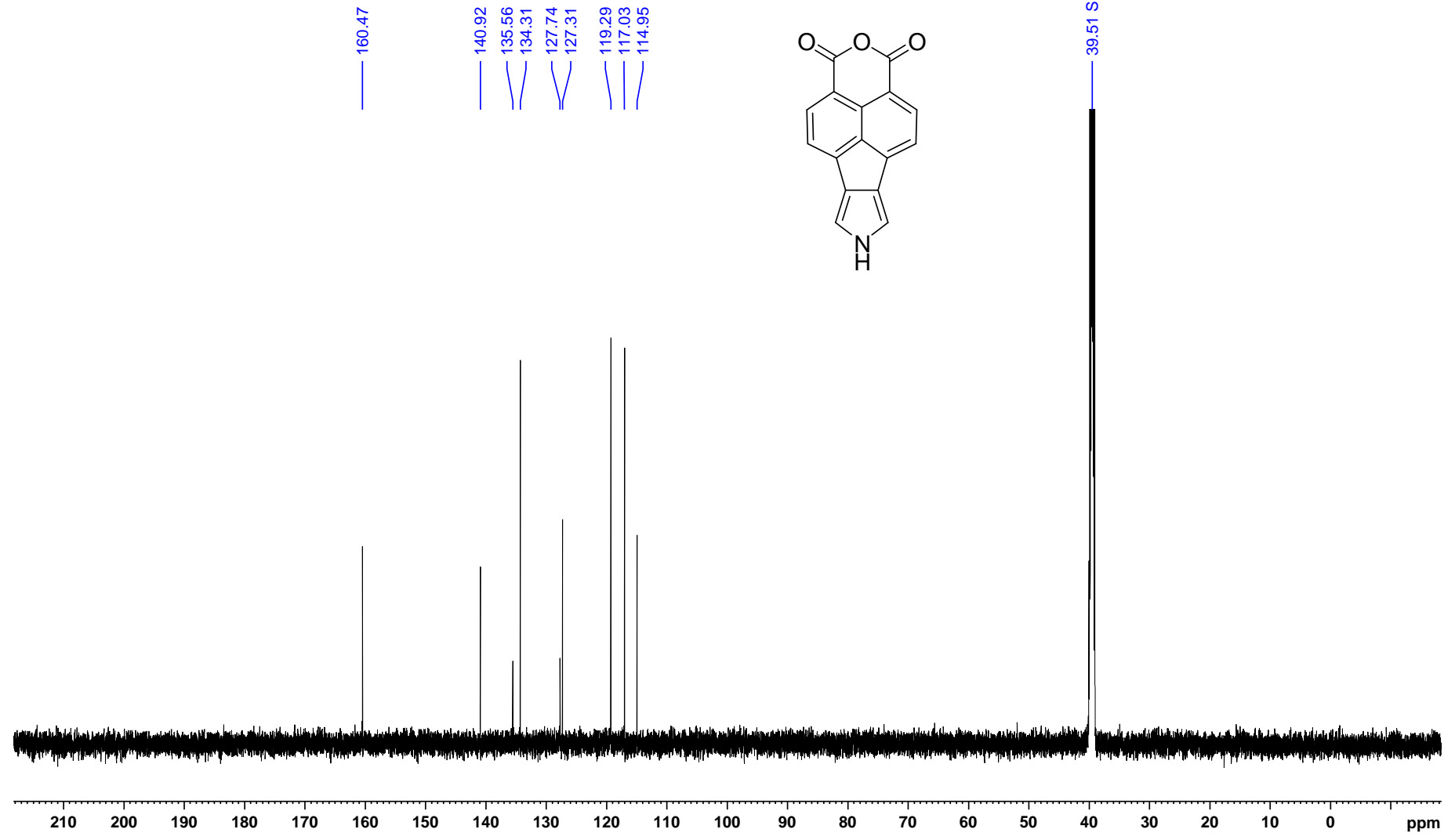

Figure S54. ${ }^{13} \mathrm{C}$ NMR spectrum of 5 (151 MHz, DMSO- $\left.d 6,300 \mathrm{~K}\right)$. 


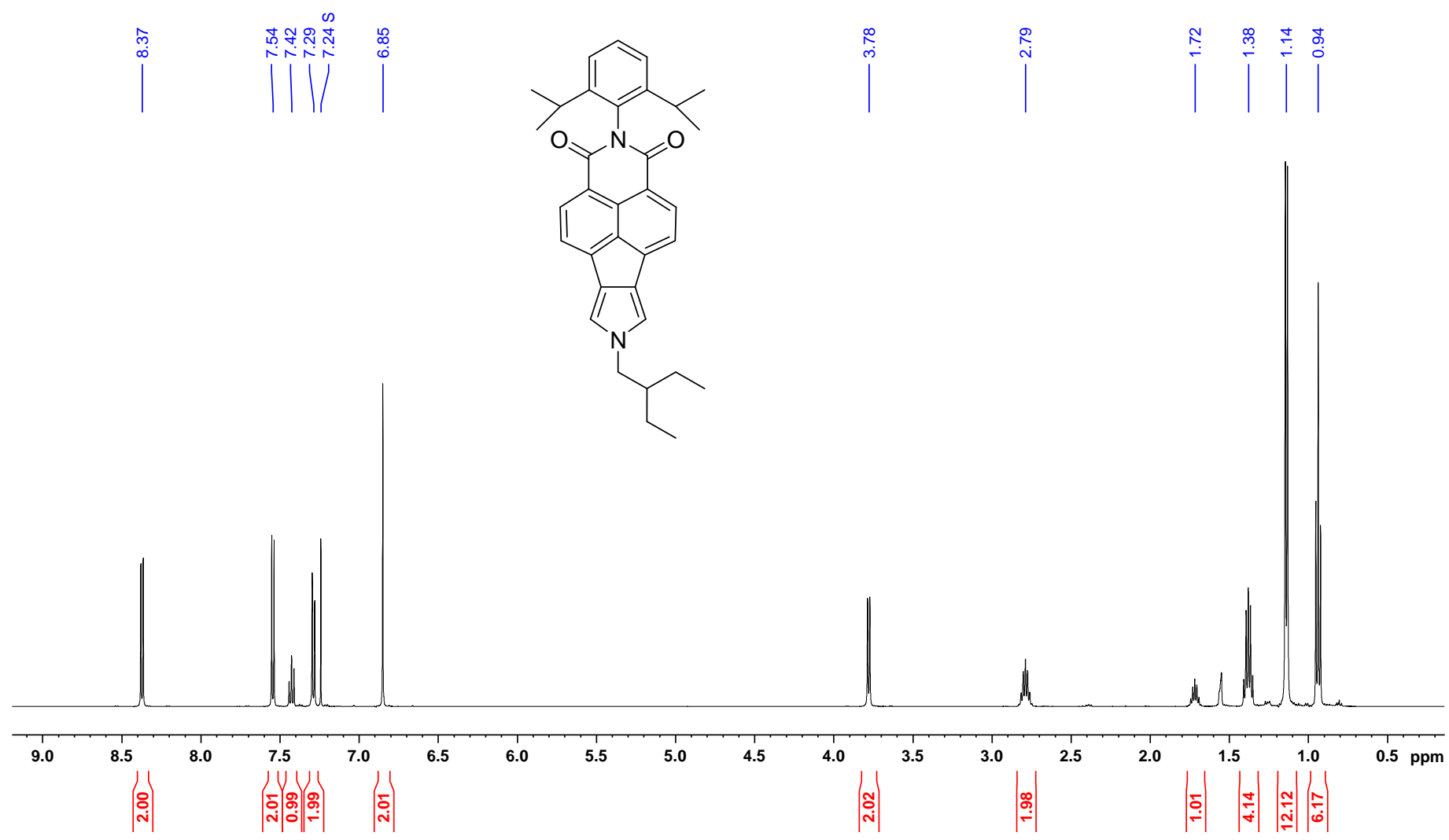

Figure S55. ${ }^{1} \mathrm{H}$ NMR spectrum of 4' (500 MHz, chloroform-d, $300 \mathrm{~K}$ ).
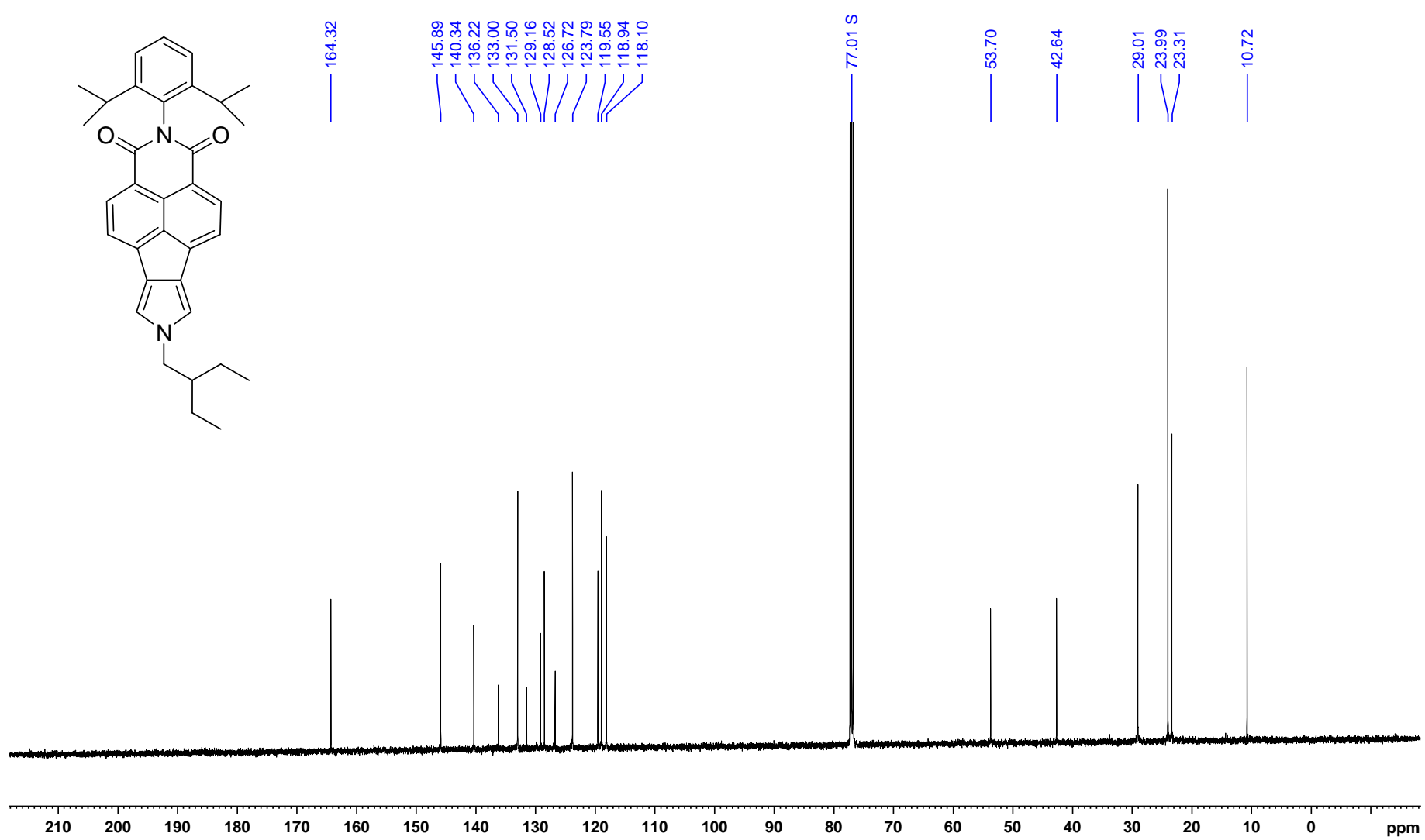

Figure S56. ${ }^{13} \mathrm{C}$ NMR spectrum of 4' (125 MHz, chloroform- $d, 300 \mathrm{~K}$ ). 


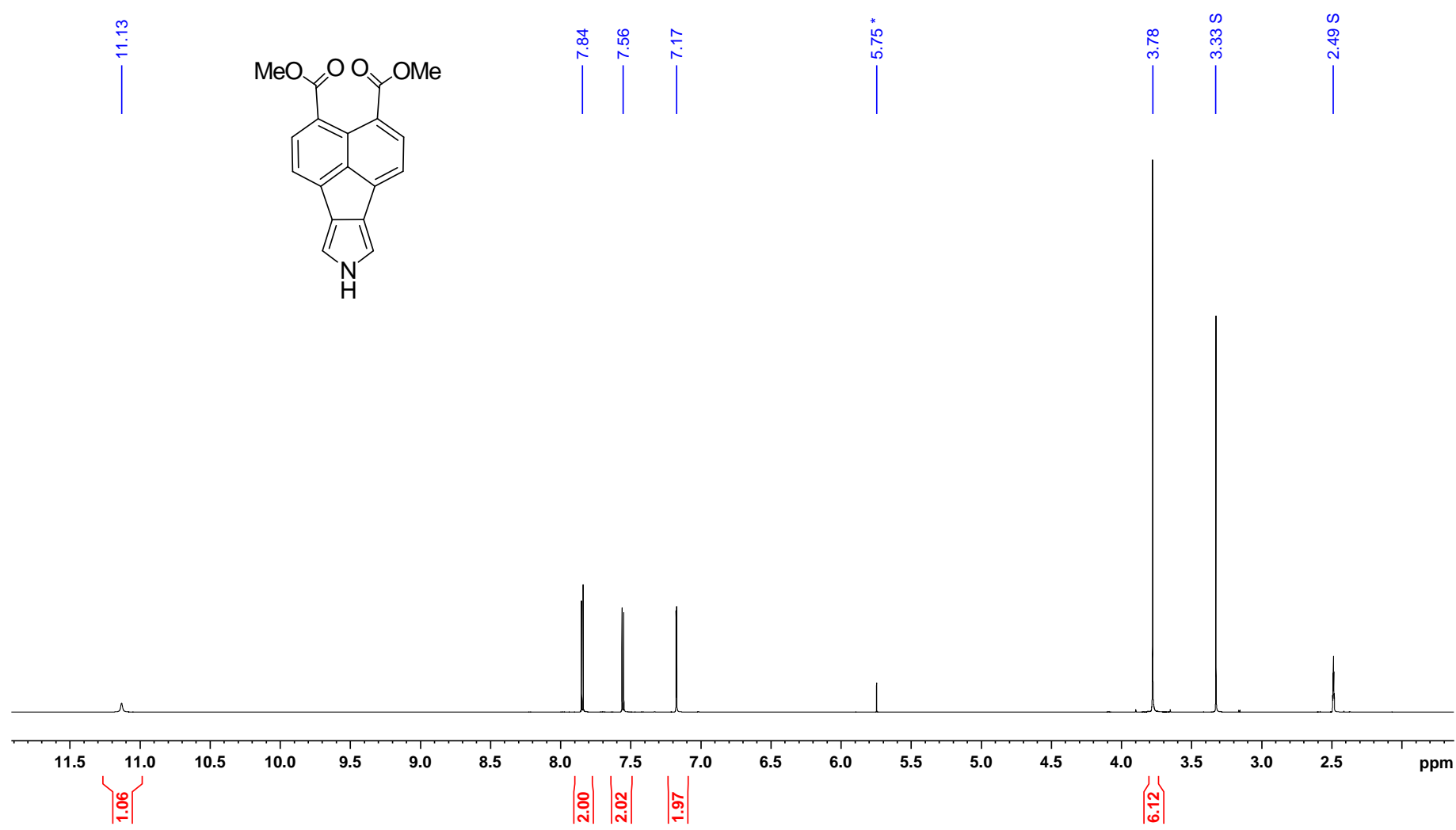

Figure S57. ${ }^{1} \mathrm{H}$ NMR spectrum of $3(600 \mathrm{MHz}$, DMSO-d6, $300 \mathrm{~K})$.

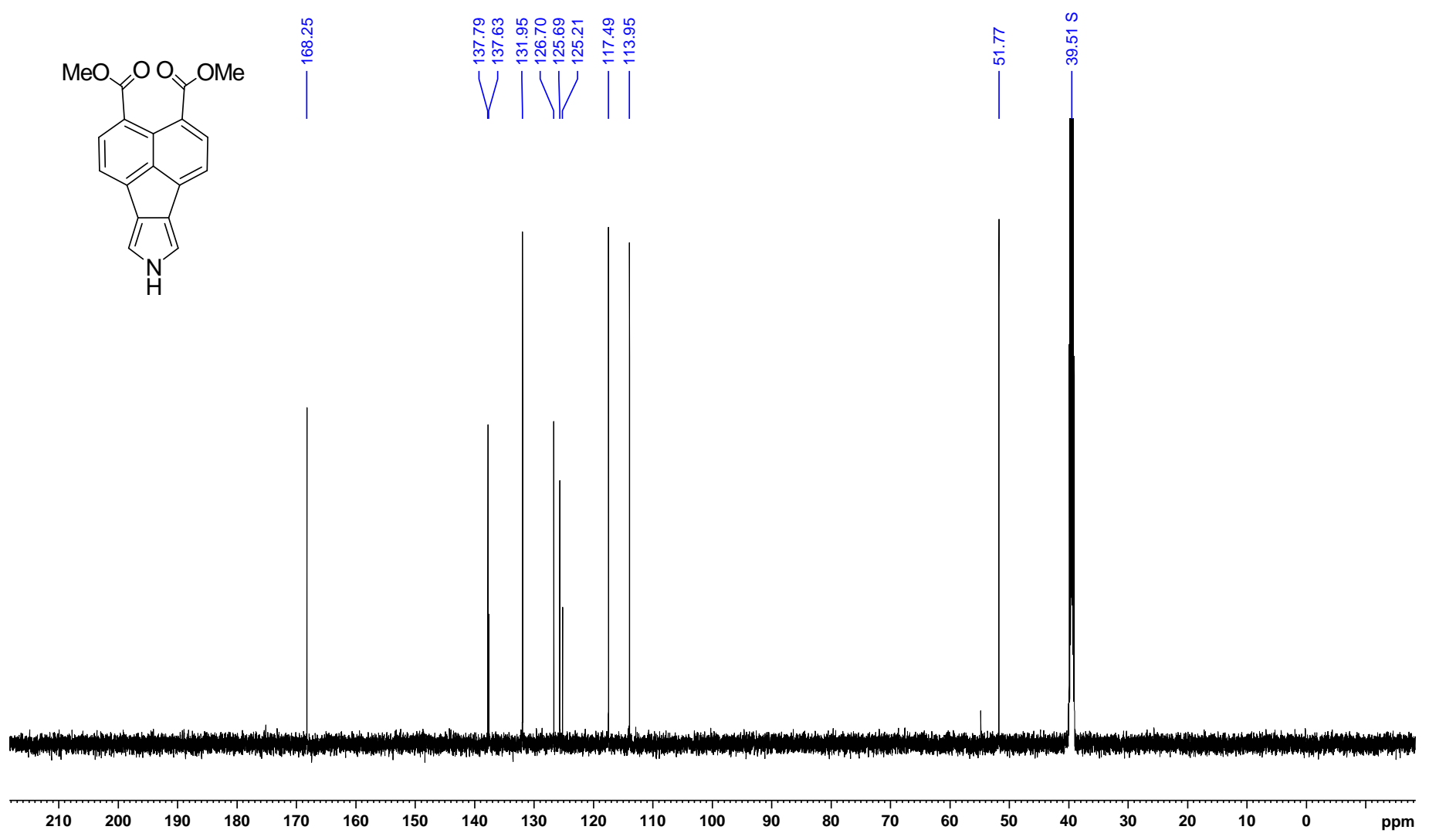

Figure S58. ${ }^{13} \mathrm{C}$ NMR spectrum of 3 (151 MHz, DMSO- $\left.d 6,300 \mathrm{~K}\right)$. 


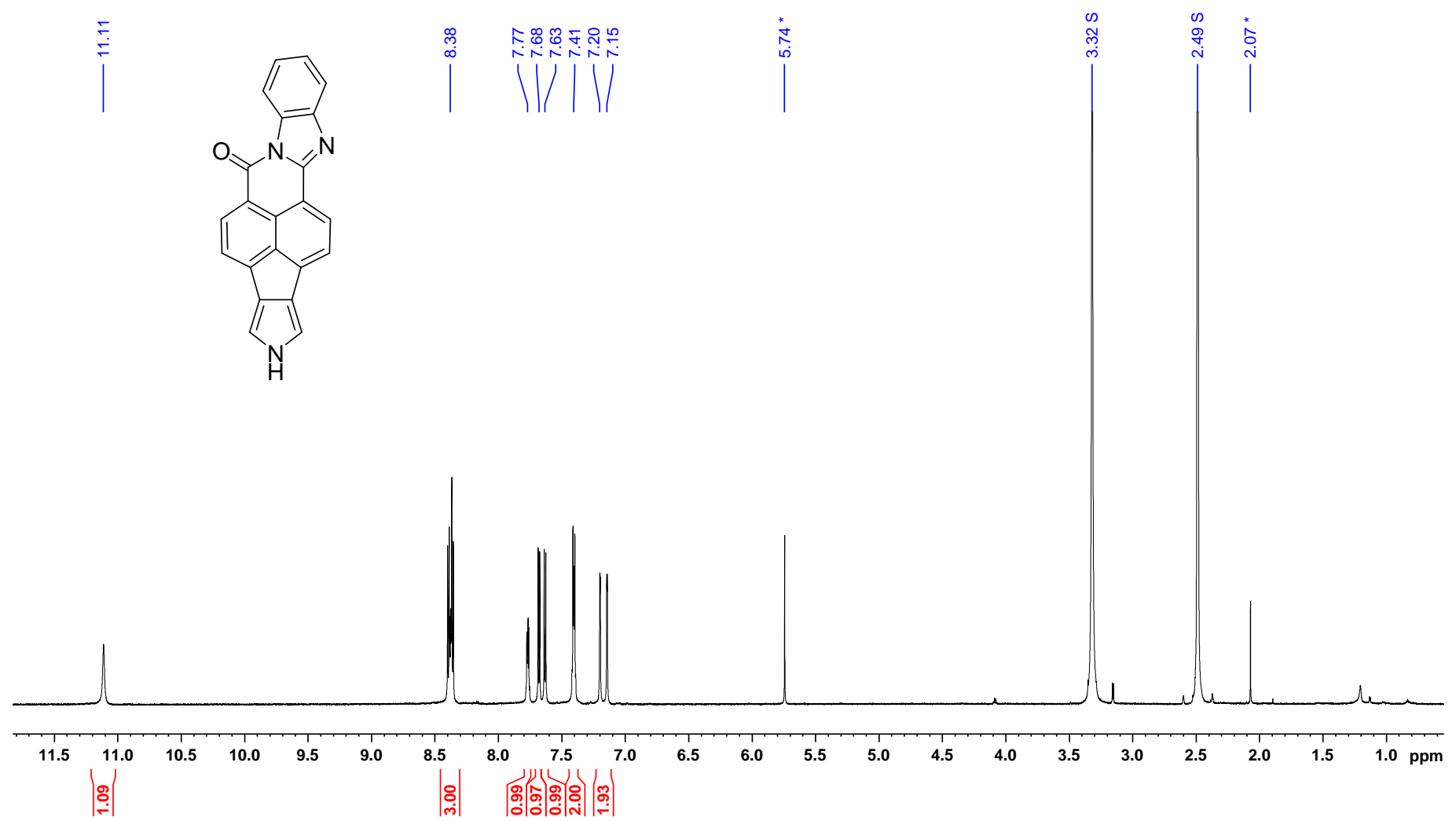

Figure S59. ${ }^{1} \mathrm{H}$ NMR spectrum of 6 (600 MHz, DMSO-d6, $\left.300 \mathrm{~K}\right)$.

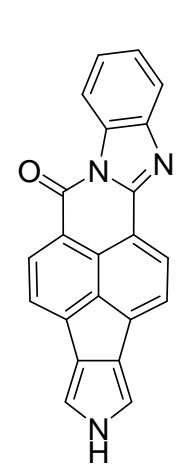

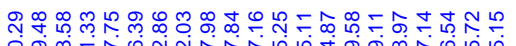

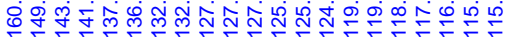
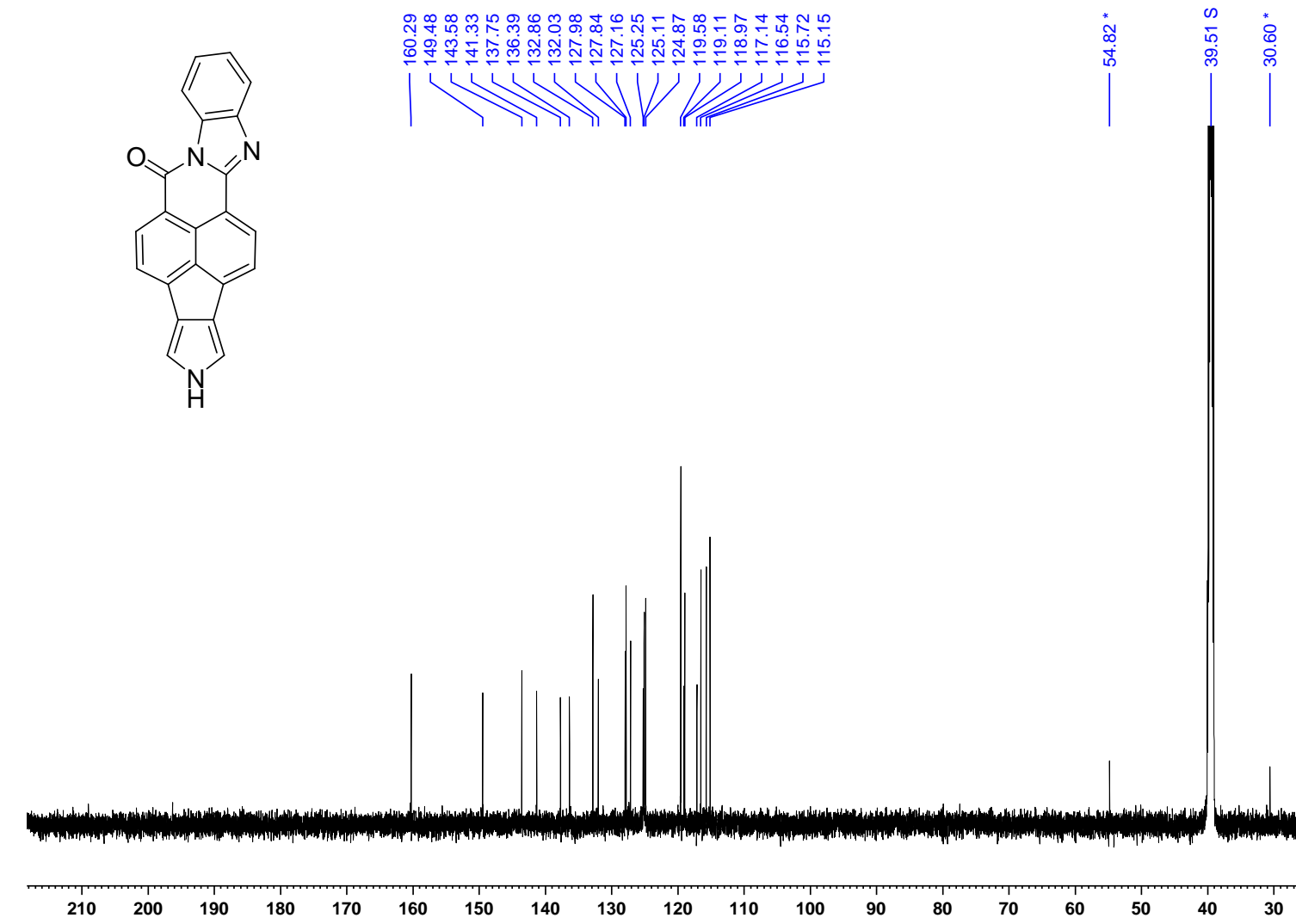

Figure S60. ${ }^{13} \mathrm{C}$ NMR spectrum of 6 [ (151 MHz, DMSO-d6, $\left.300 \mathrm{~K}\right)$. 


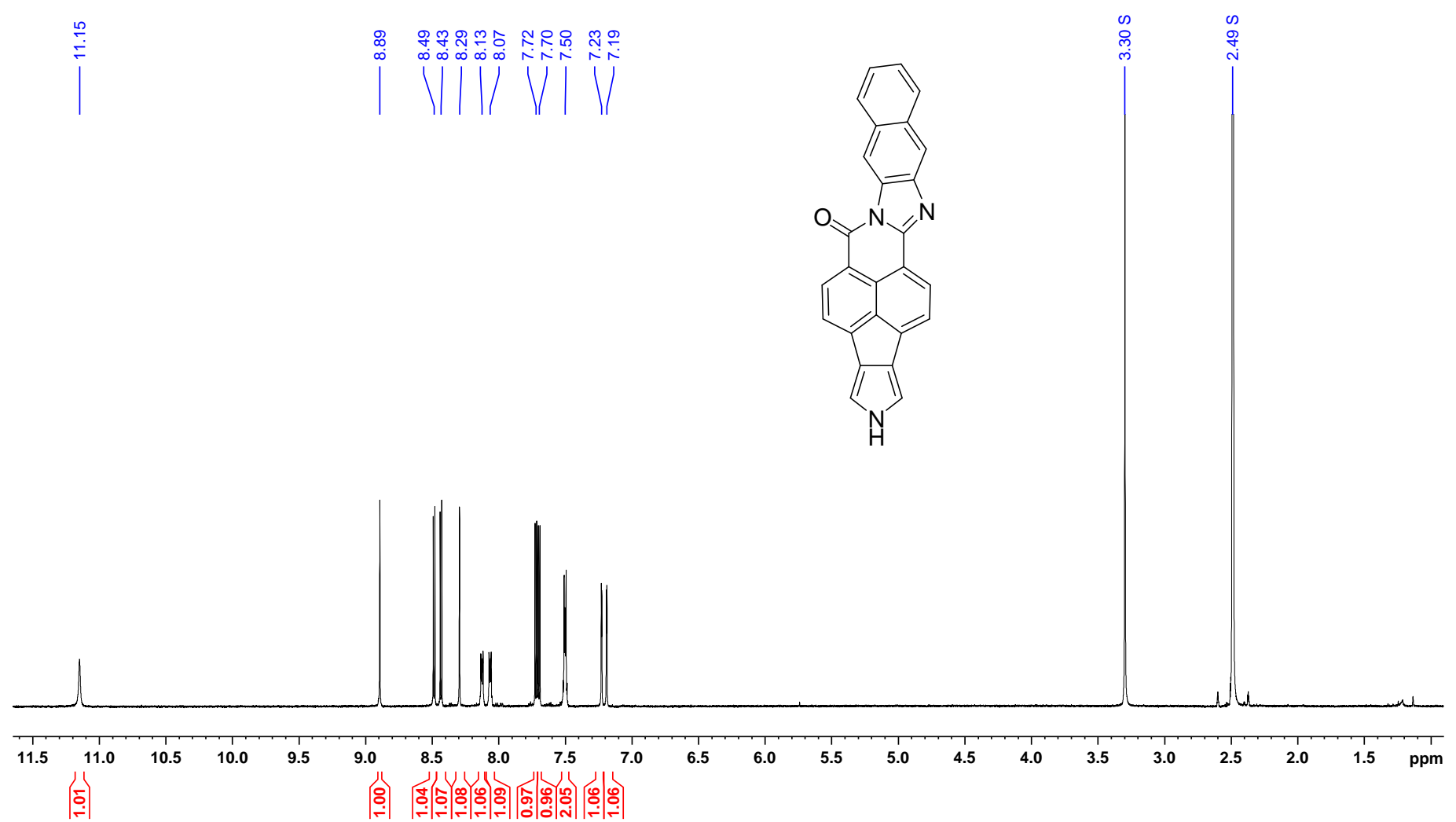

Figure S61. ${ }^{1} \mathrm{H}$ NMR spectrum of 7 (600 MHz, DMSO-d6, $\left.300 \mathrm{~K}\right)$.
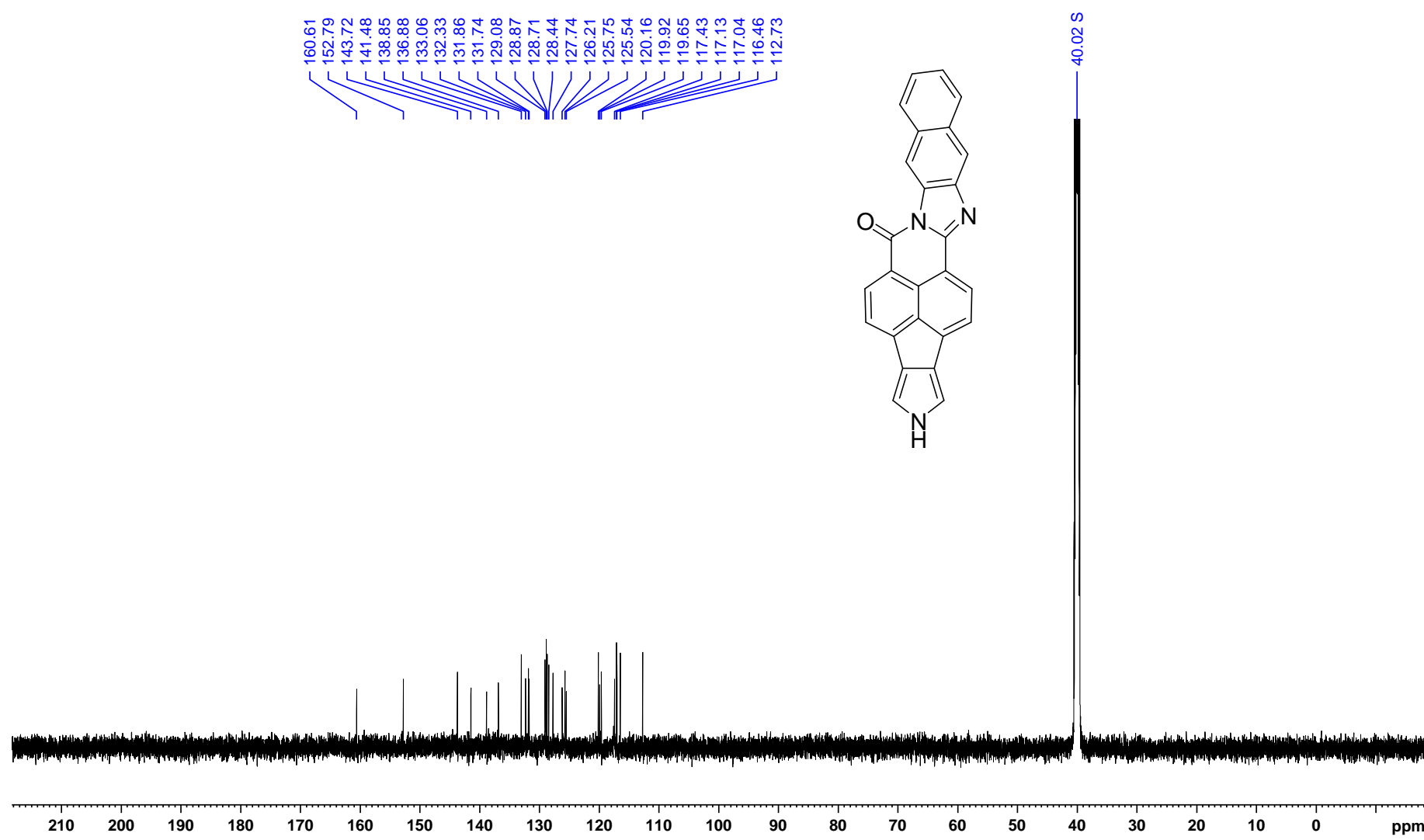

Figure S62. ${ }^{13} \mathrm{C}$ NMR spectrum of 7 (151 MHz, DMSO-d6, $300 \mathrm{~K}$ ). 


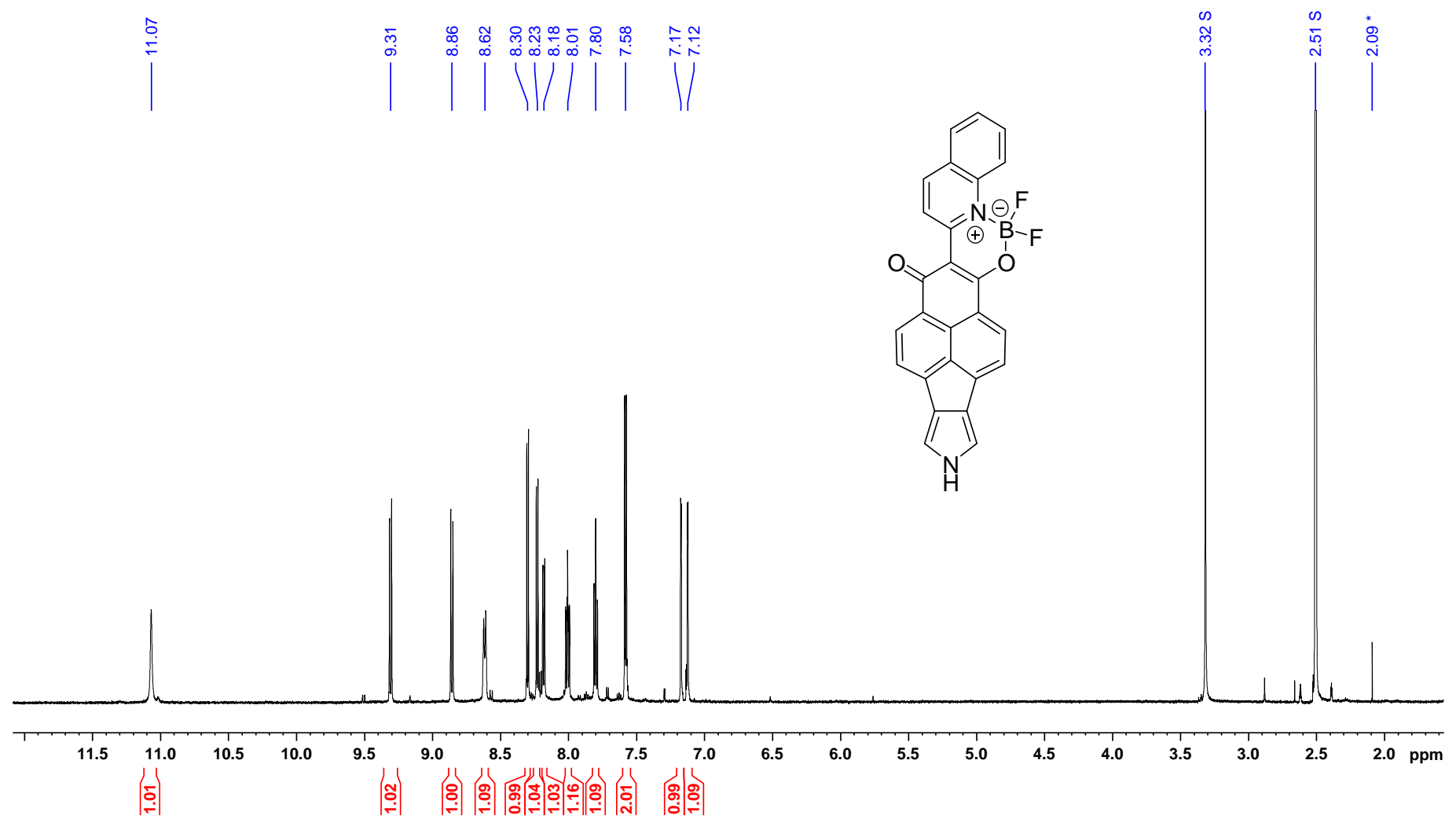

Figure S63. ${ }^{1} \mathrm{H}$ NMR spectrum of $8(600 \mathrm{MHz}$, DMSO-d6, $300 \mathrm{~K})$.

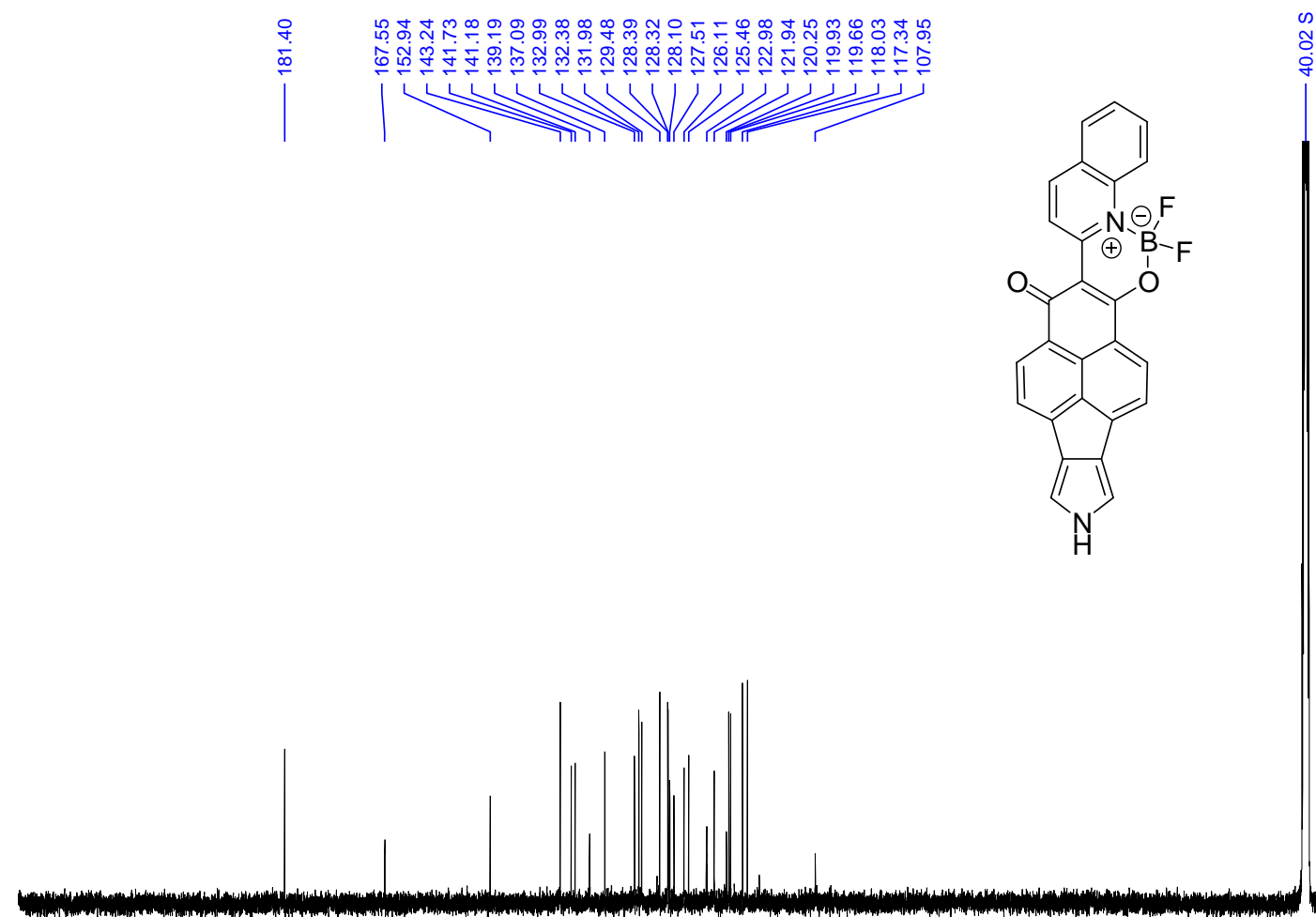

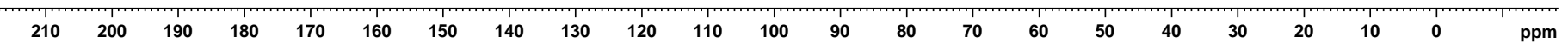

Figure S64. ${ }^{13} \mathrm{C}$ NMR spectrum of 8 (151 MHz, DMSO-d6, $\left.300 \mathrm{~K}\right)$. 


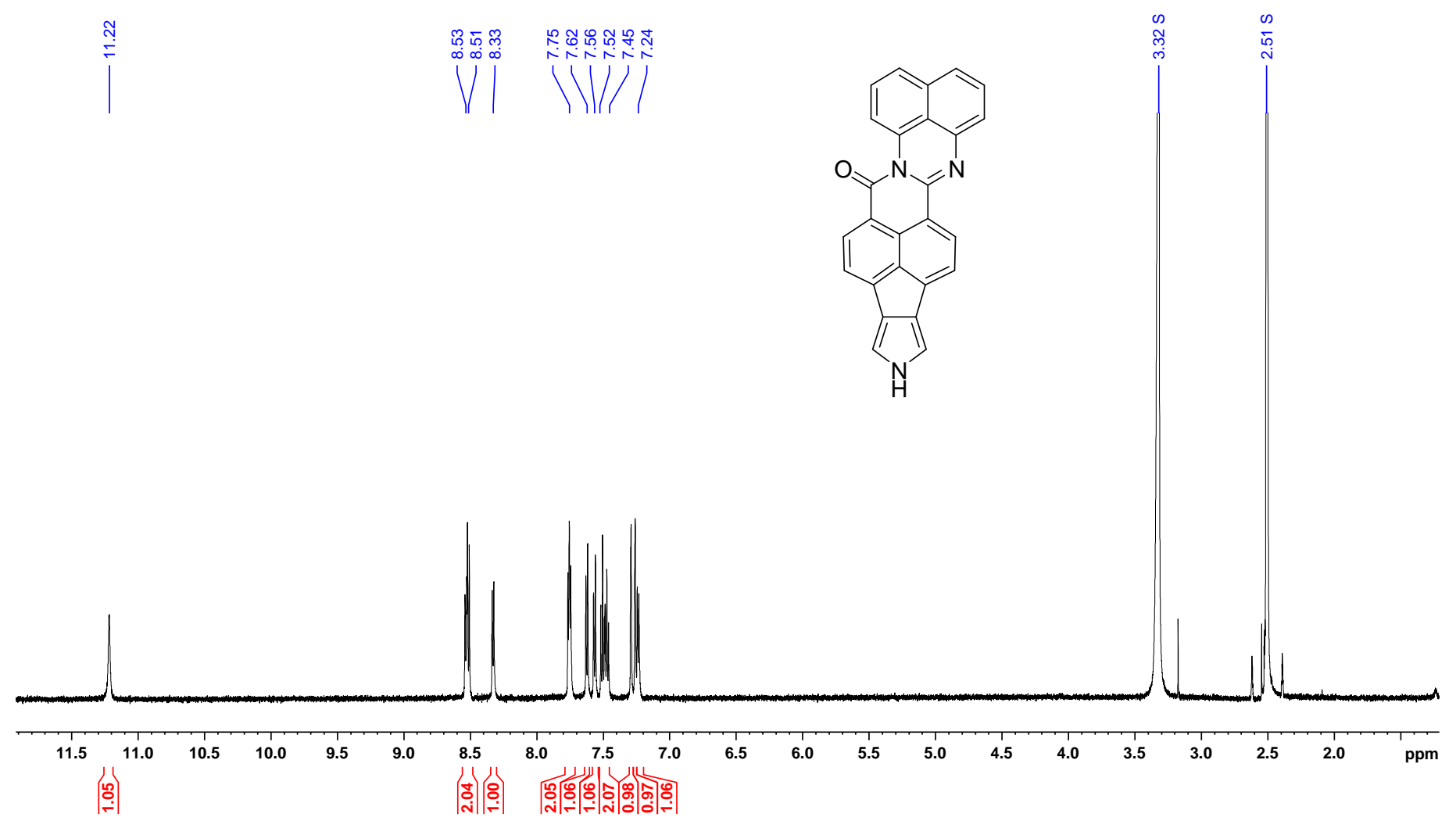

Figure S65. ${ }^{1} \mathrm{H}$ NMR spectrum of 9 (600 MHz, DMSO-d6, $\left.300 \mathrm{~K}\right)$.
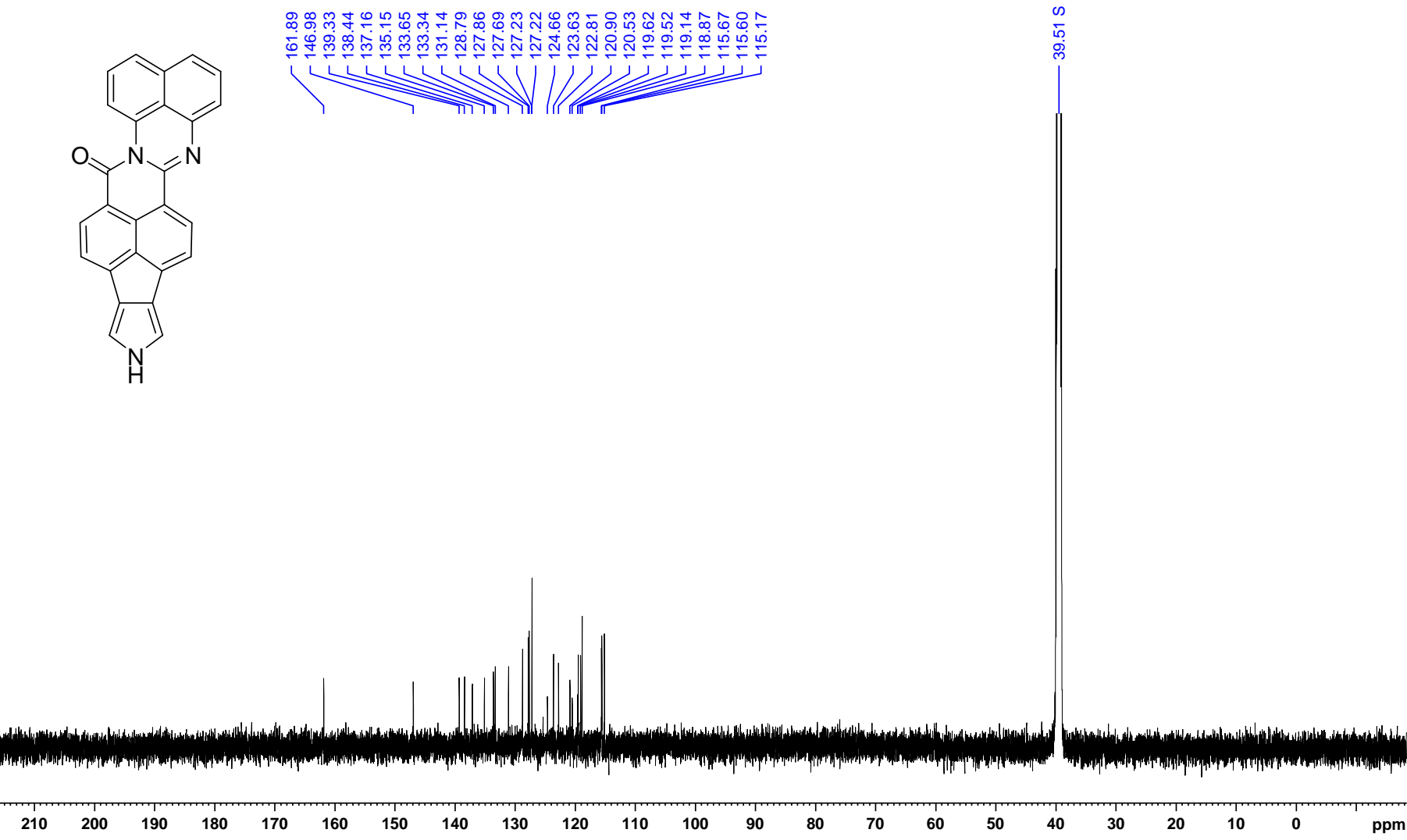

Figure S66. ${ }^{13} \mathrm{C}$ NMR spectrum of 9 (151 MHz, DMSO- $\left.d 6,300 \mathrm{~K}\right)$. 


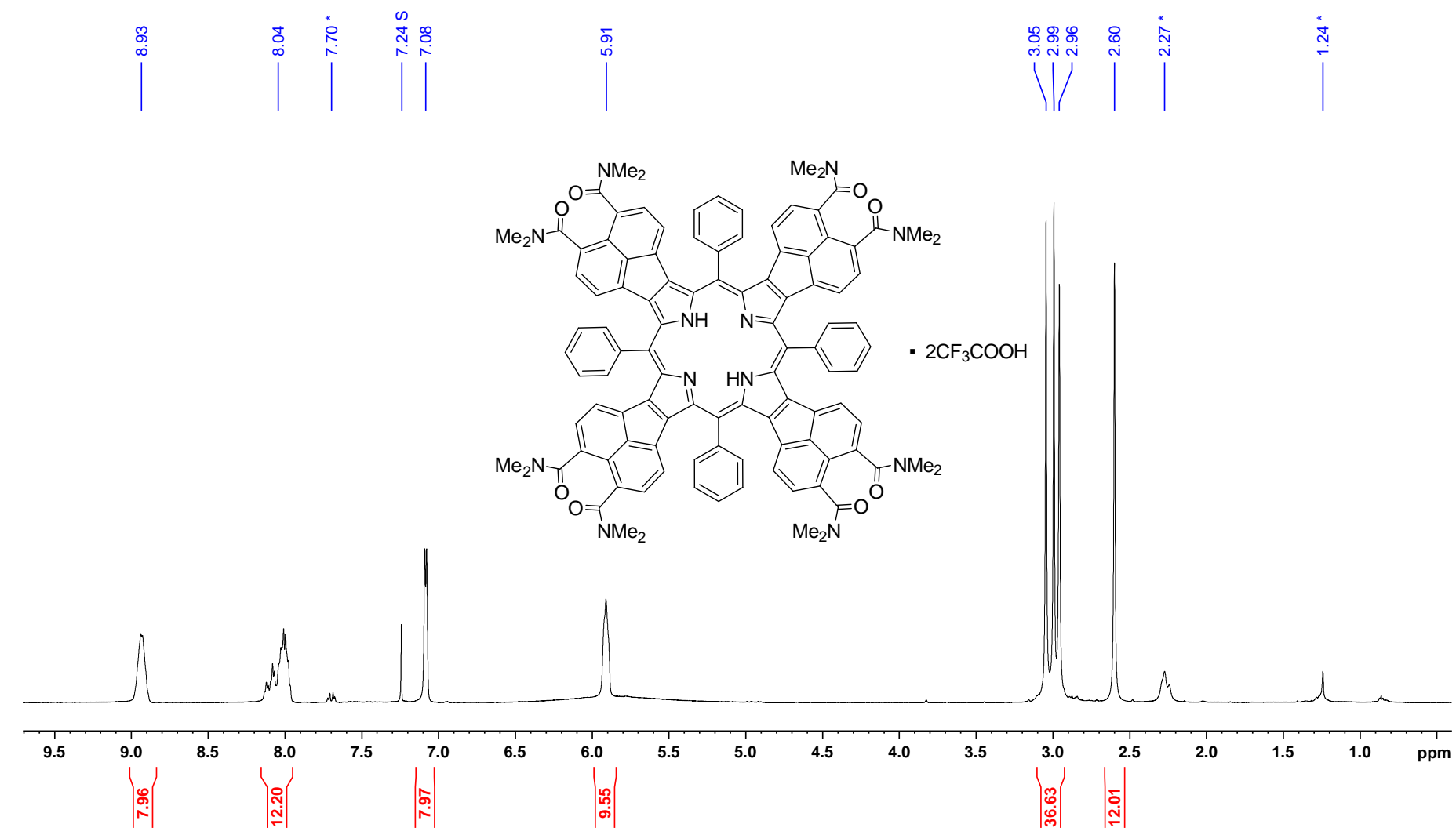

Figure S67. ${ }^{1} \mathrm{H}$ NMR spectrum of $\left[10-\mathrm{H}_{4}\right][\mathrm{TFA}]_{2}(600 \mathrm{MHz}$, chloroform- $d, 300 \mathrm{~K})$.
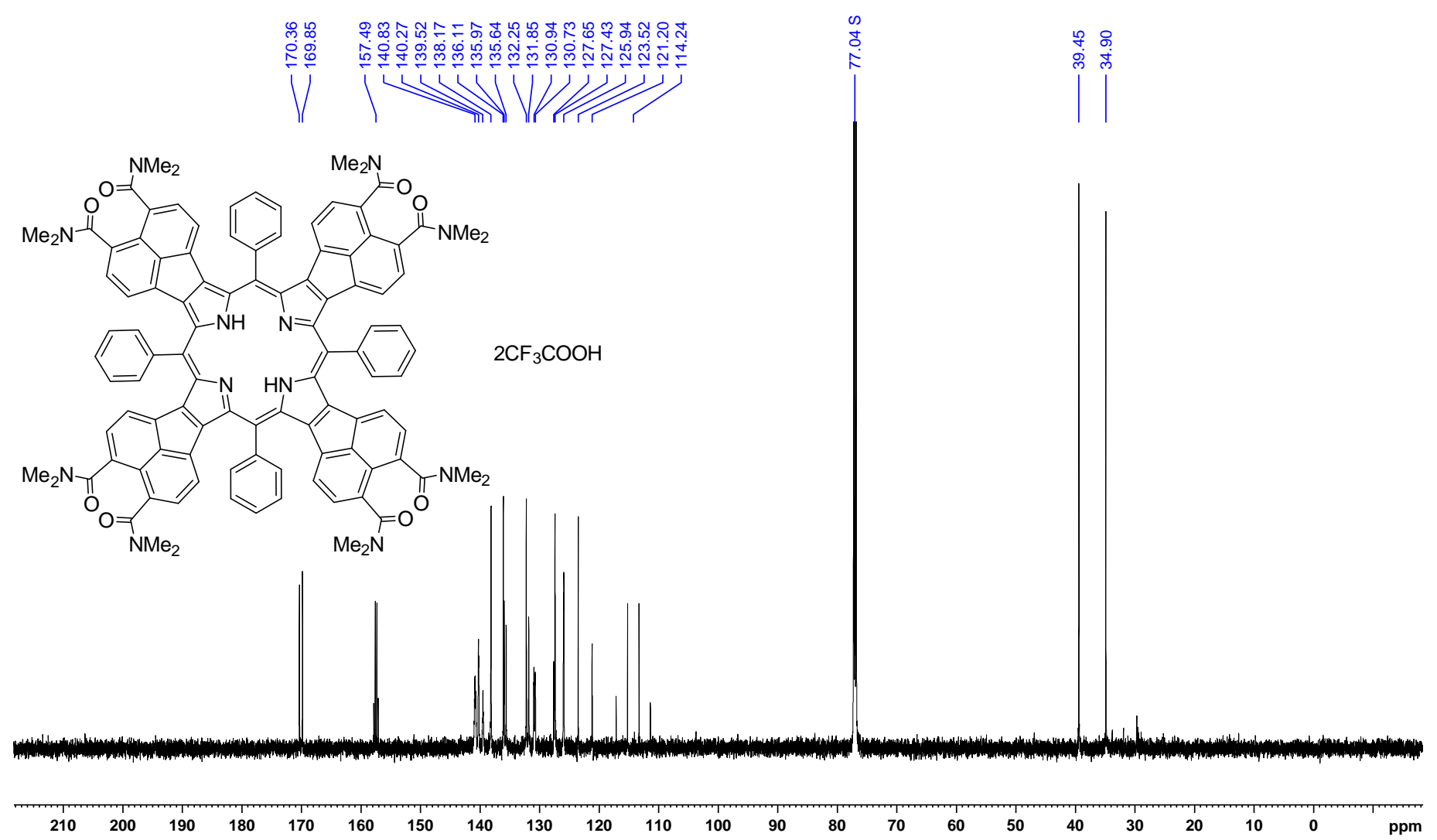

Figure S68. ${ }^{13} \mathrm{C}$ NMR spectrum of $\left[10-\mathrm{H}_{4}\right][\mathrm{TFA}]_{2}(151 \mathrm{MHz}$, chloroform-d, $300 \mathrm{~K})$. 


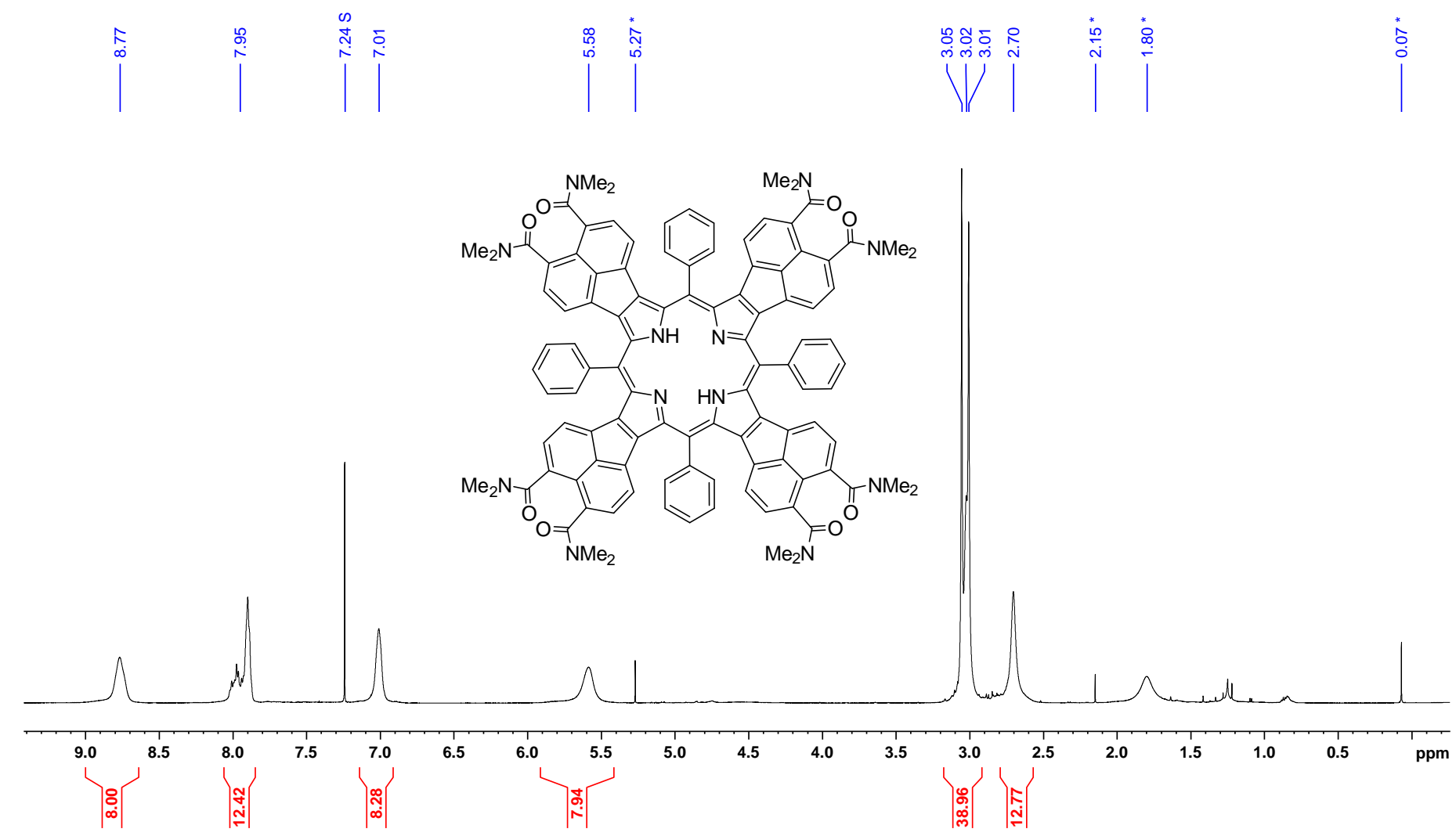

Figure S69. ${ }^{1} \mathrm{H}$ NMR spectrum of $10-\mathrm{H}_{2}(600 \mathrm{MHz}$, chloroform-d, $300 \mathrm{~K})$.

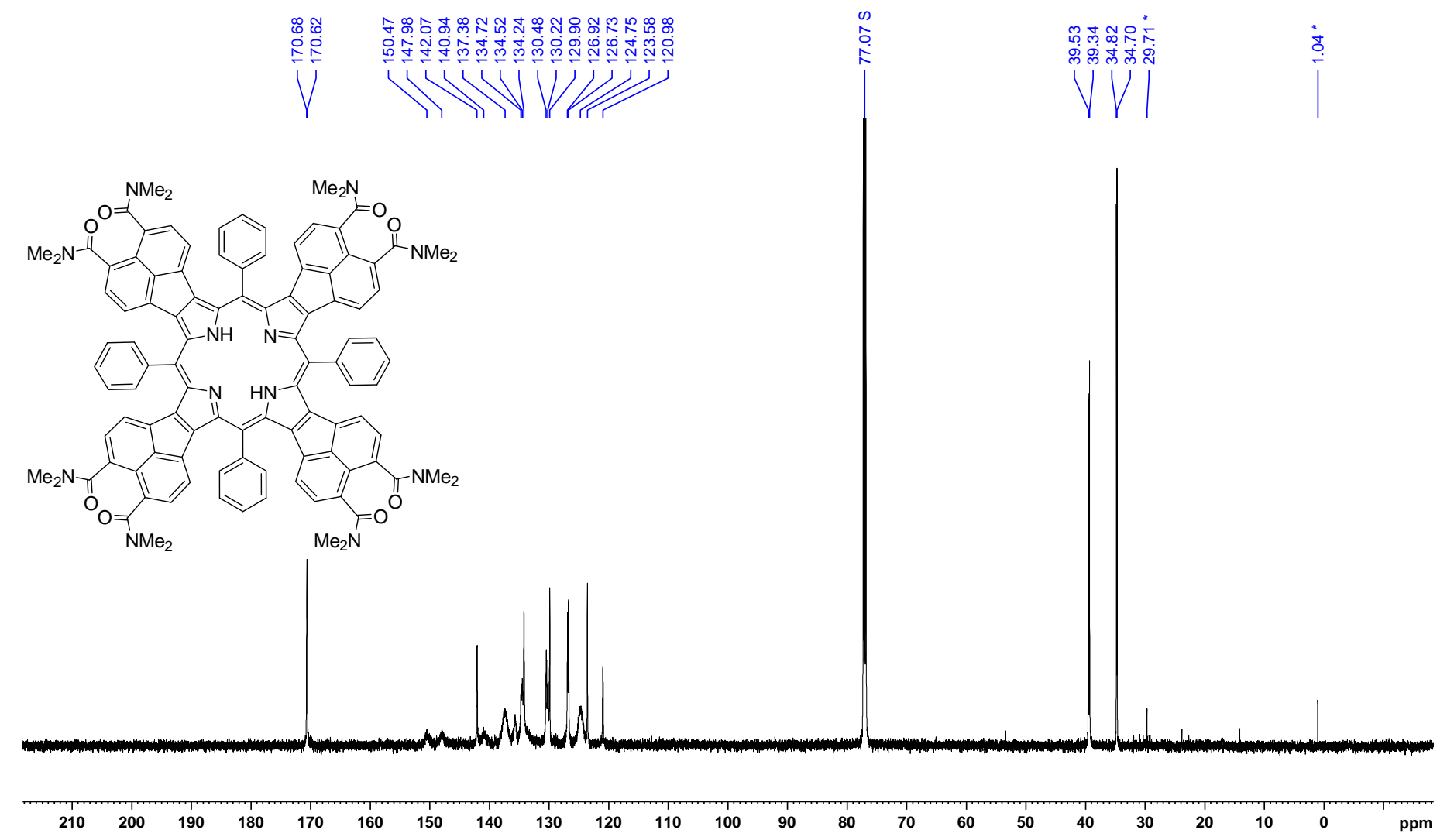

Figure S70. ${ }^{13} \mathrm{C}$ NMR spectrum of $\mathbf{1 0}-\mathrm{H}_{2}(151 \mathrm{MHz}$, chloroform- $d, 300 \mathrm{~K})$. 


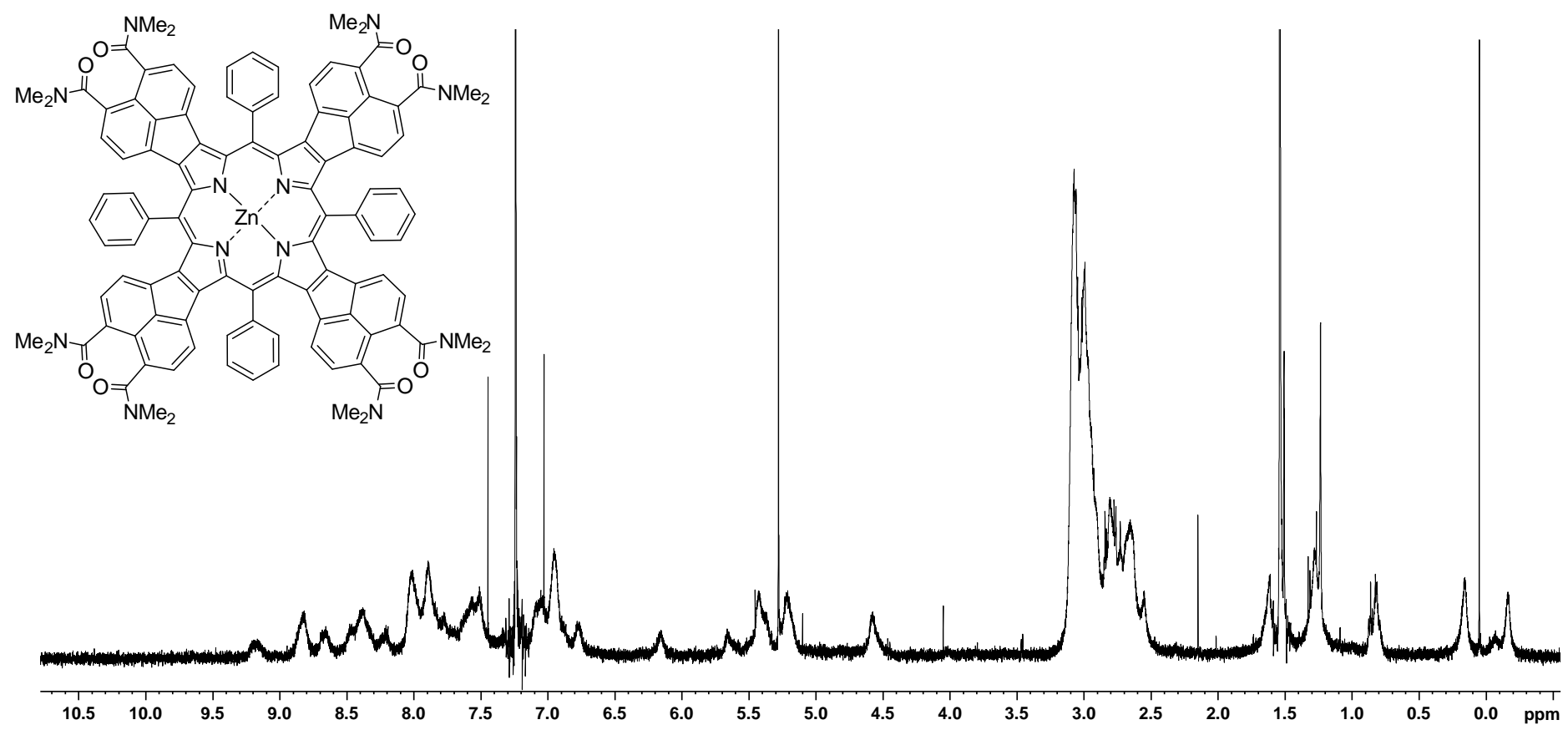

Figure S71. ${ }^{1} \mathrm{H}$ NMR spectrum of $10-\mathrm{Zn}(500 \mathrm{MHz}$, chloroform- $d$, $300 \mathrm{~K})$.

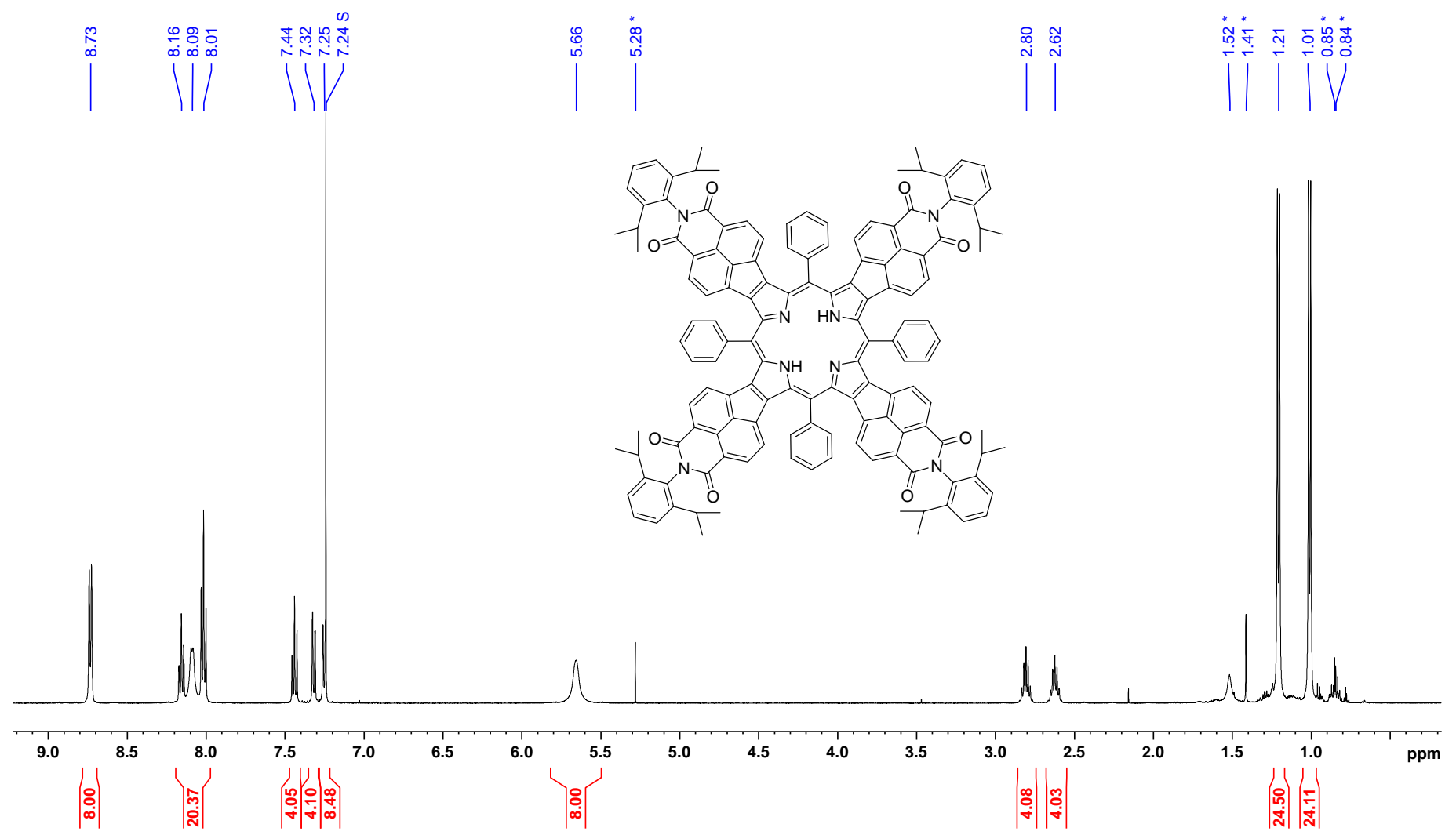

Figure S72. ${ }^{1} \mathrm{H}$ NMR spectrum of $11-\mathrm{H}_{2}(500 \mathrm{MHz}$, chloroform-d, $300 \mathrm{~K})$. 


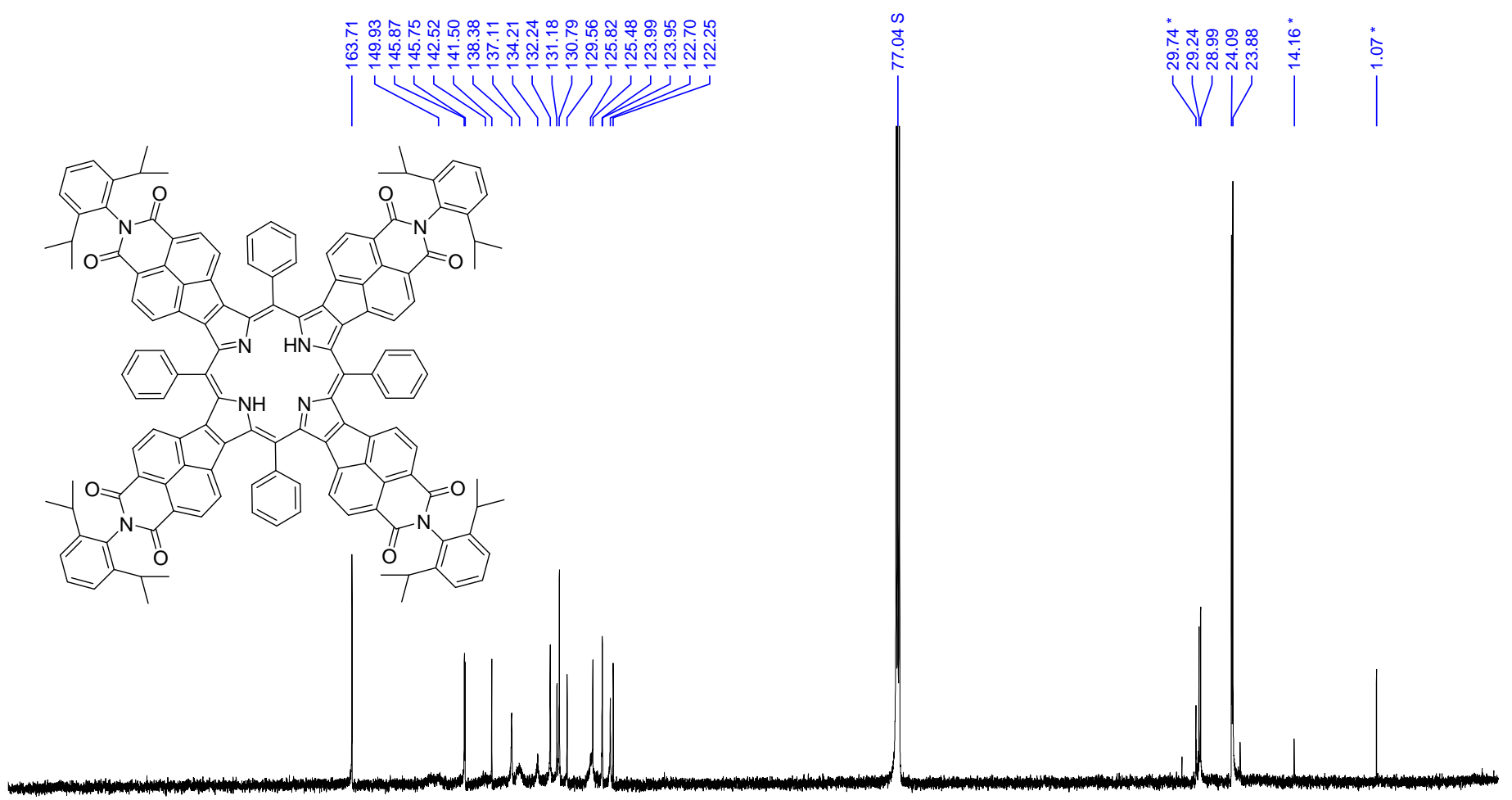

$\begin{array}{lllllllllllllllllllllllllllllllll}210 & 200 & 190 & 180 & 170 & 160 & 150 & 140 & 130 & 120 & 110 & 100 & 90 & 80 & 70 & 60 & 50 & 40 & 30 & 20 & 10 & 0 & \mathrm{ppm}\end{array}$

Figure S73. ${ }^{13} \mathrm{C}$ NMR spectrum of $11-\mathrm{H}_{2}(125 \mathrm{MHz}$, chloroform- $d, 300 \mathrm{~K})$.
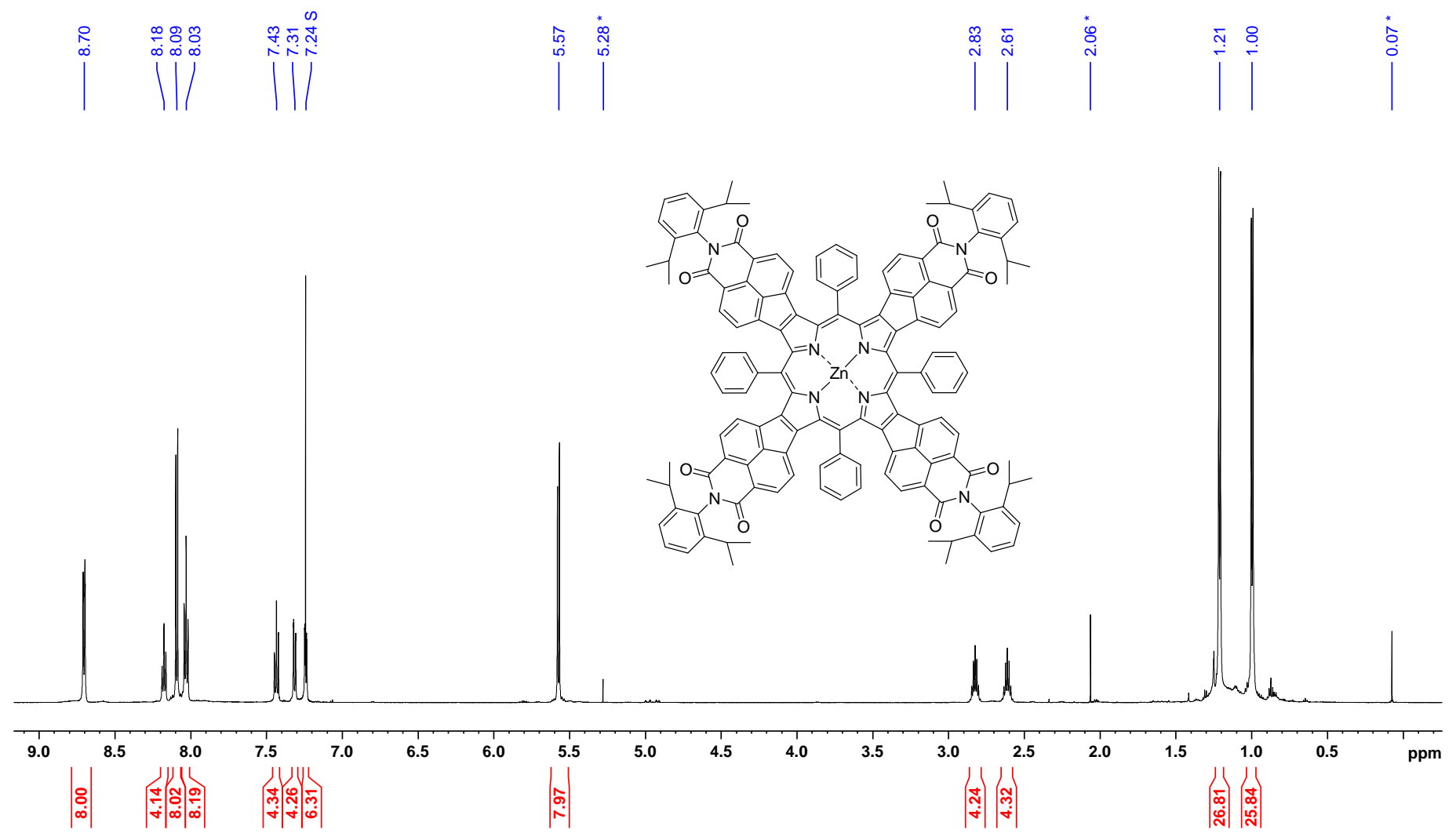

Figure S74. ${ }^{1} \mathrm{H}$ NMR spectrum of 11-Zn (600 MHz, chloroform-d, $300 \mathrm{~K}$ ). 


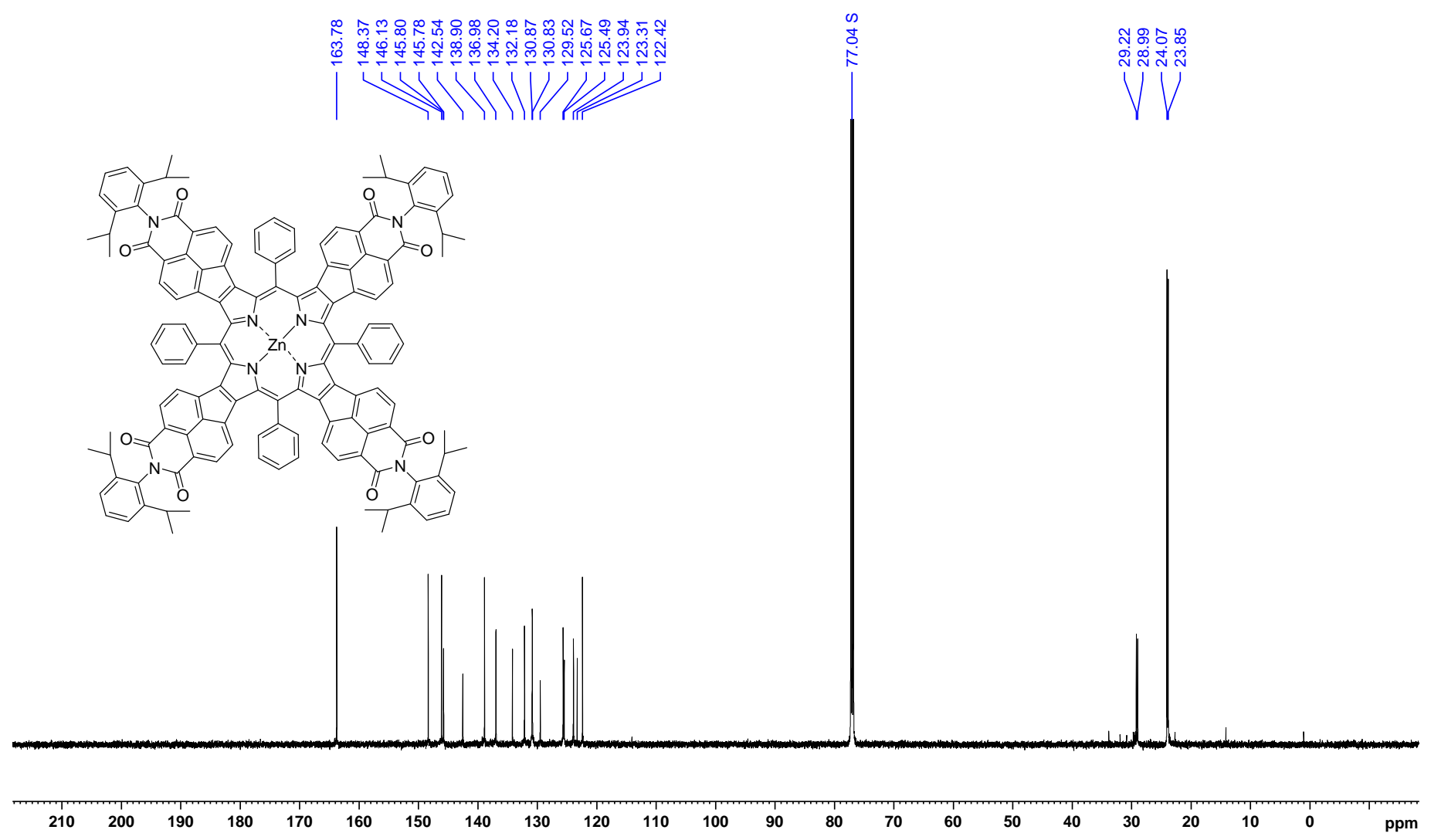

Figure S75. ${ }^{13} \mathrm{C}$ NMR spectrum of 11-Zn (151 MHz, chloroform-d, $300 \mathrm{~K}$ ). 


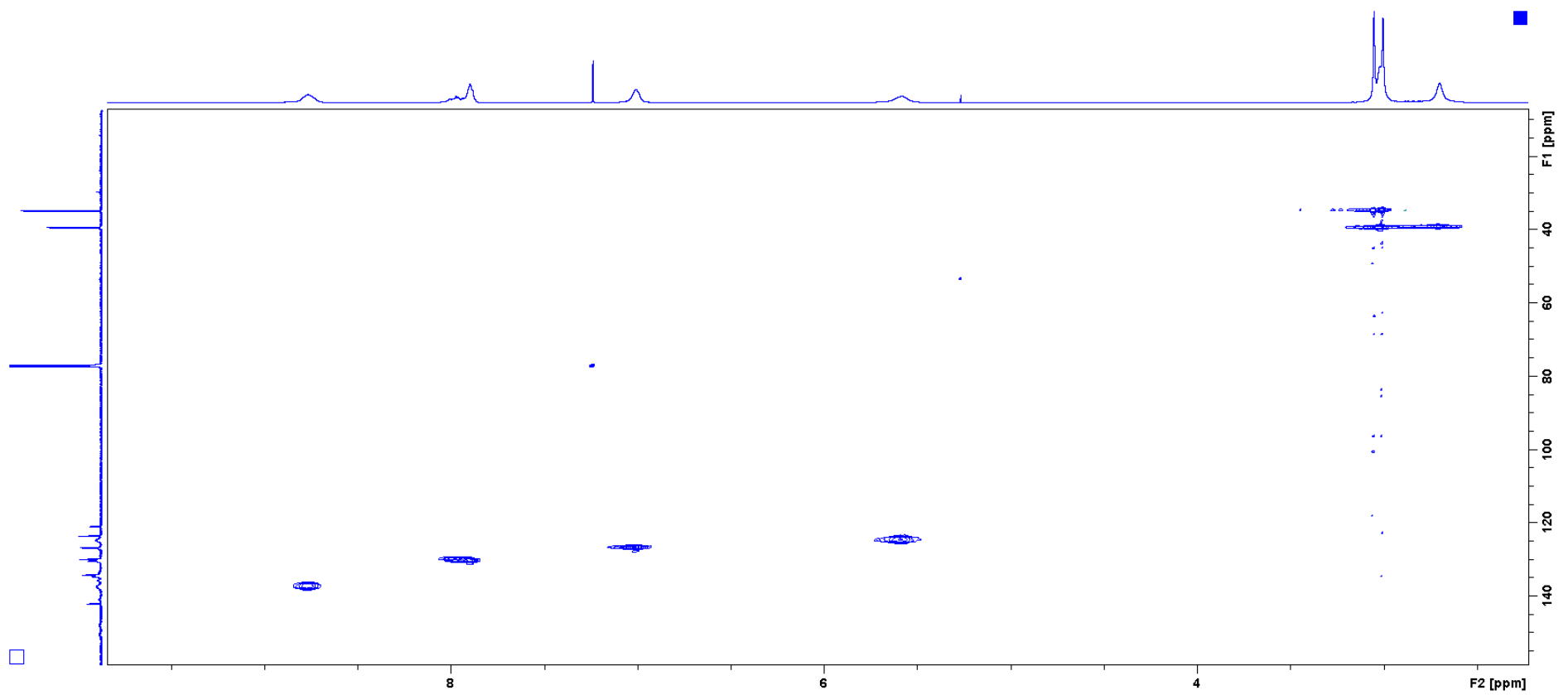

Figure S76. ${ }^{1} \mathrm{H}^{13} \mathrm{C}$ HSQC spectrum for $\mathbf{1 0}-\mathrm{H}_{\mathbf{2}}$ (chloroform- $d$, $300 \mathrm{~K}, 600 \mathrm{MHz}$ ).

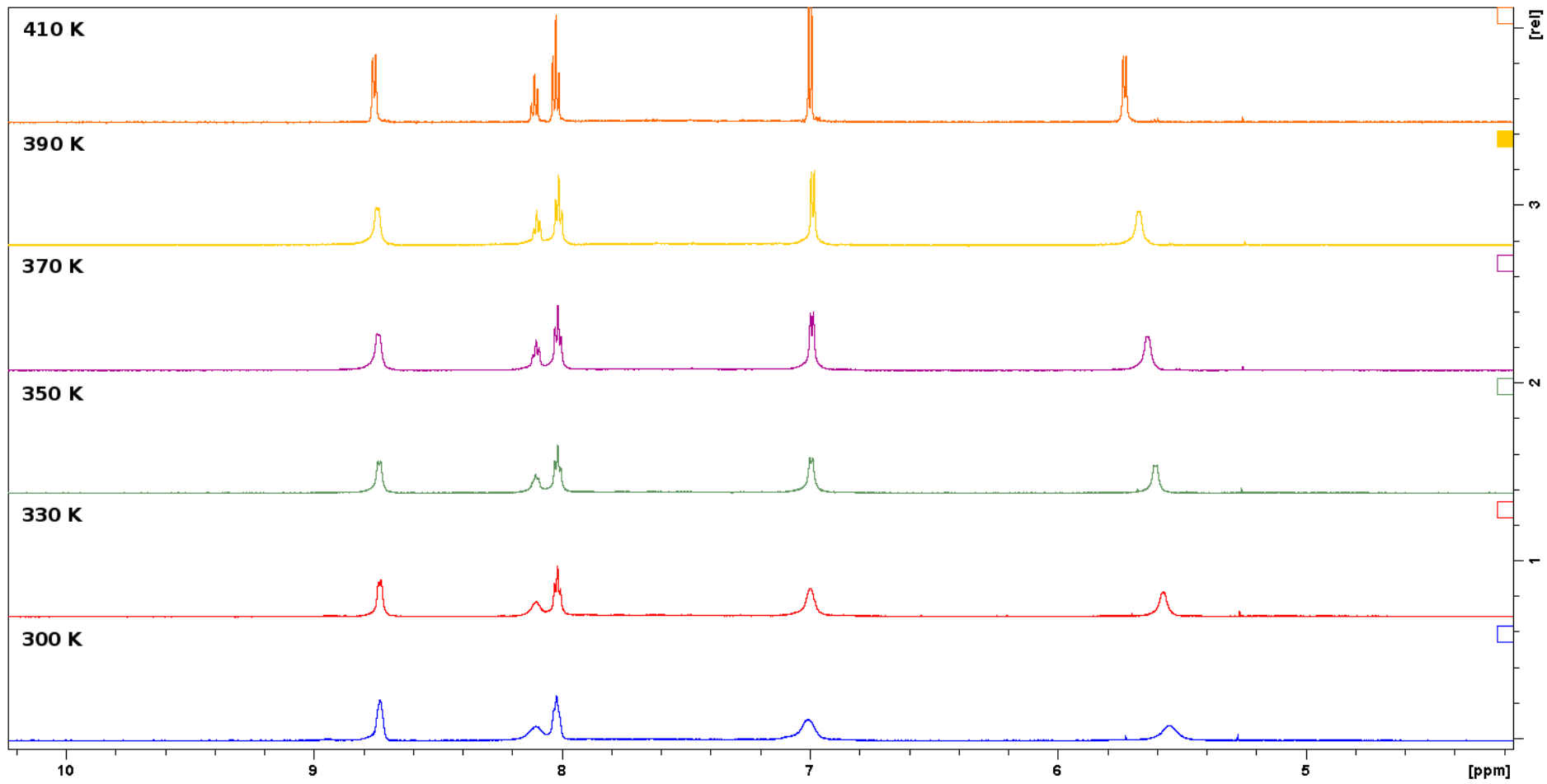

Figure S77. Changes in ${ }^{1} \mathrm{H}$ NMR spectrum of $\mathbf{1 0}-\mathrm{H}_{\mathbf{2}}$ with temperature increasing (DMSO- $d_{6}, 600 \mathrm{MHz}$ ). 


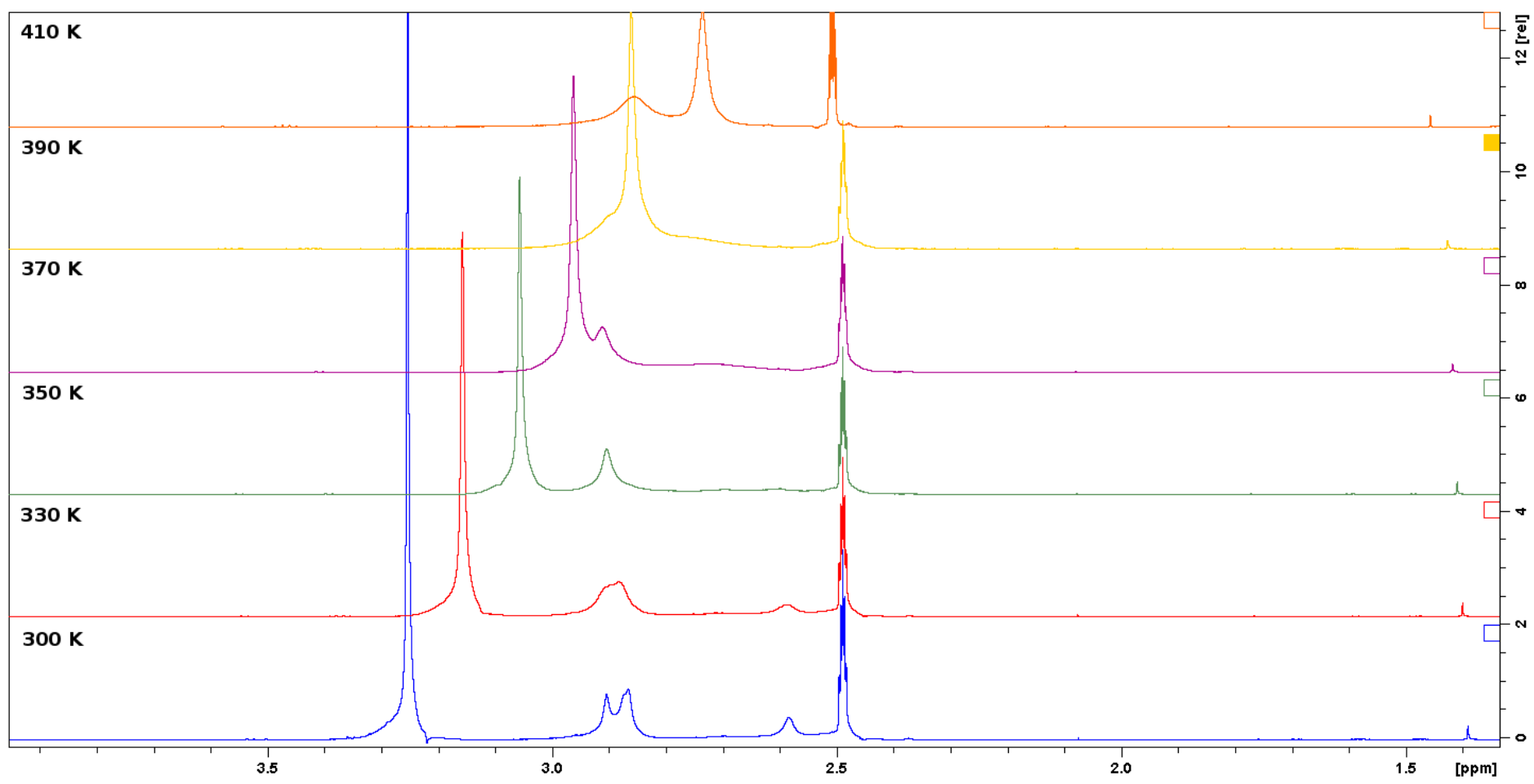

Figure S78. Changes in ${ }^{1} \mathrm{H}$ NMR spectrum of $\mathbf{1 0}-\mathrm{H}_{2}$ with temperature increasing (DMSO- $d_{6}, 600 \mathrm{MHz}$ ). 
Mass Spectra 


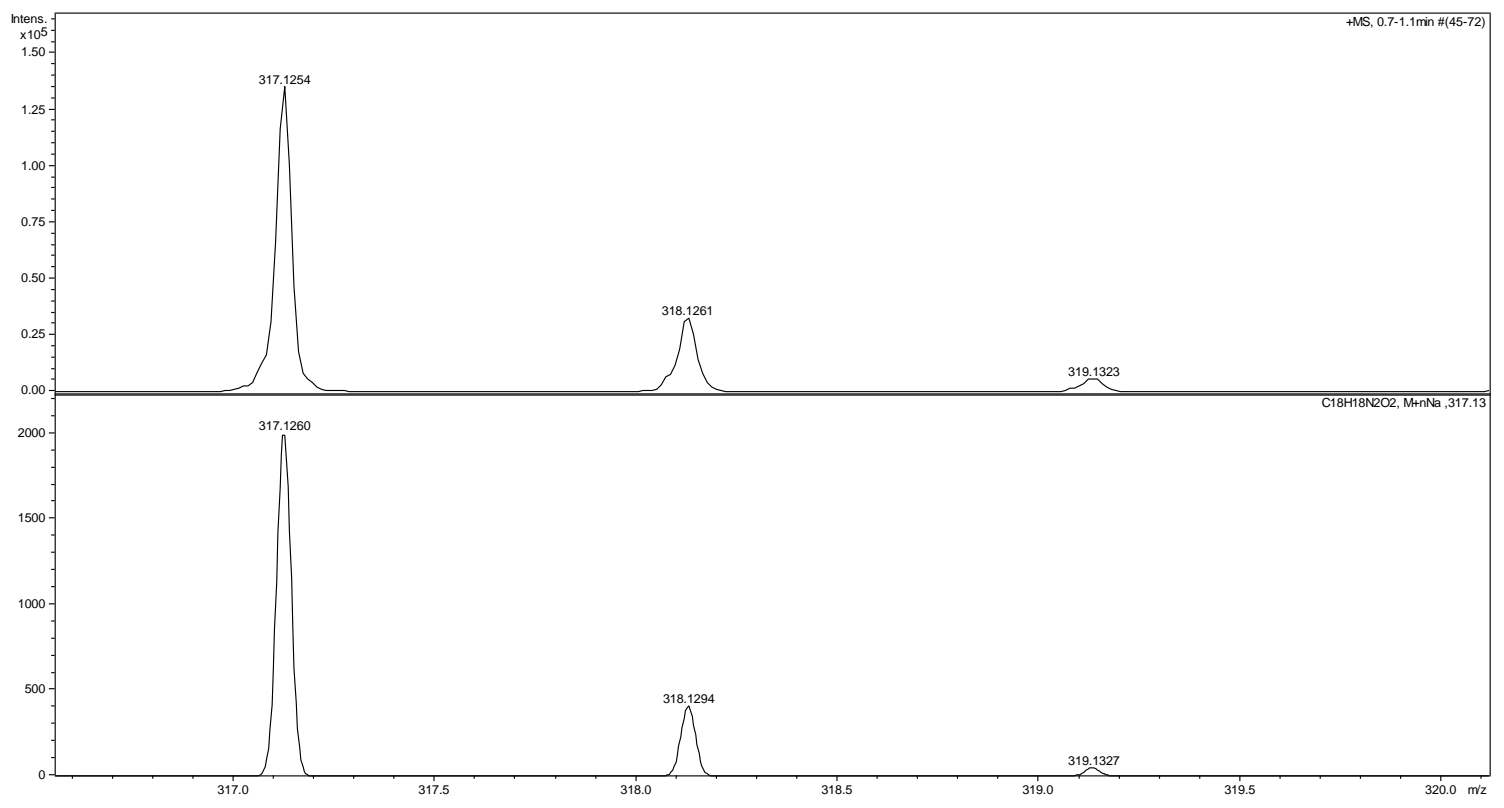

Figure S79. High resolution mass spectrum of S3 (HRMS, ESI-TOF, top: experimental, bottom: simulated).

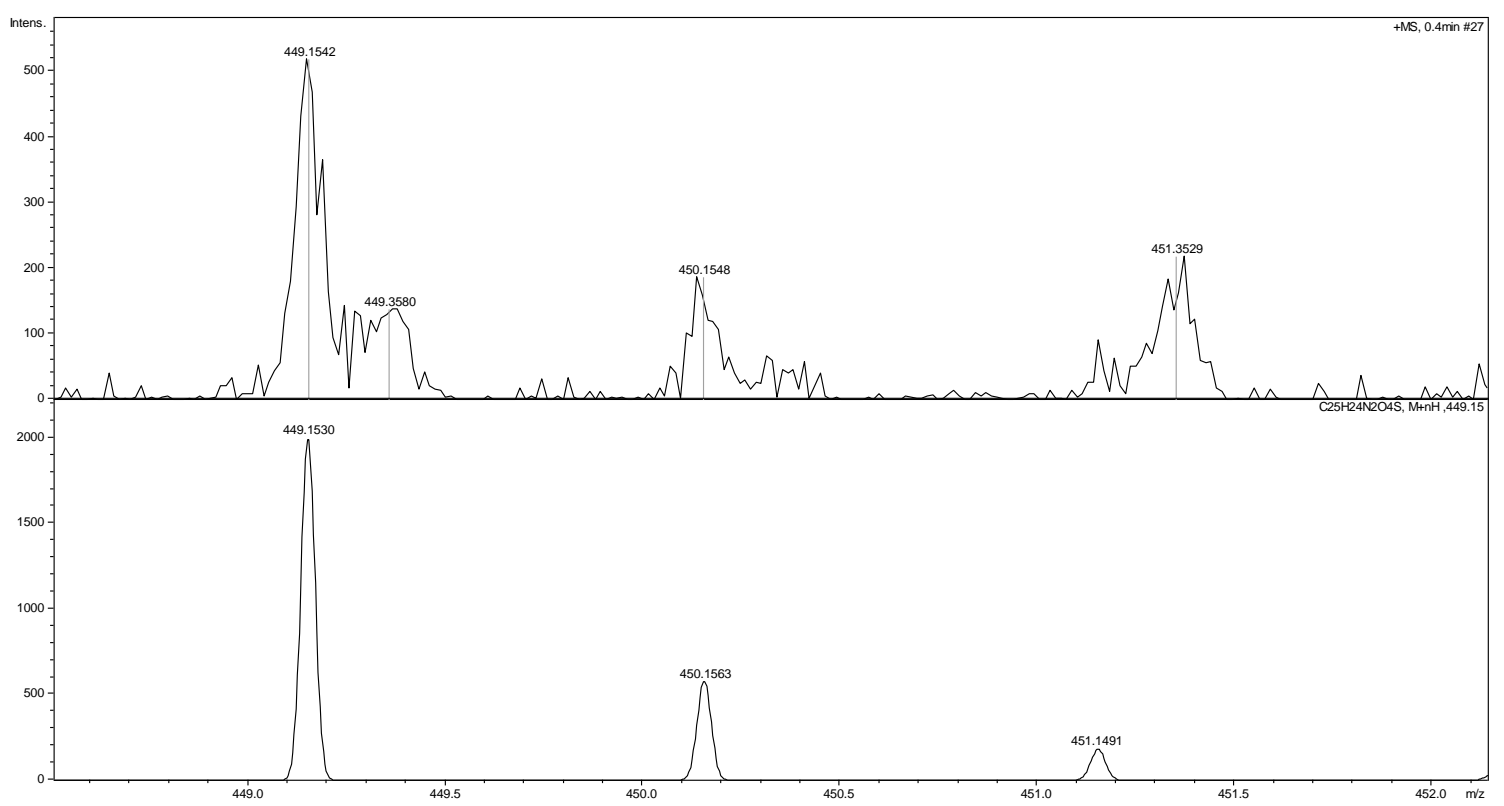

Figure S80. High resolution mass spectrum of S4 (HRMS, ESI-TOF, top: experimental, bottom: simulated). 


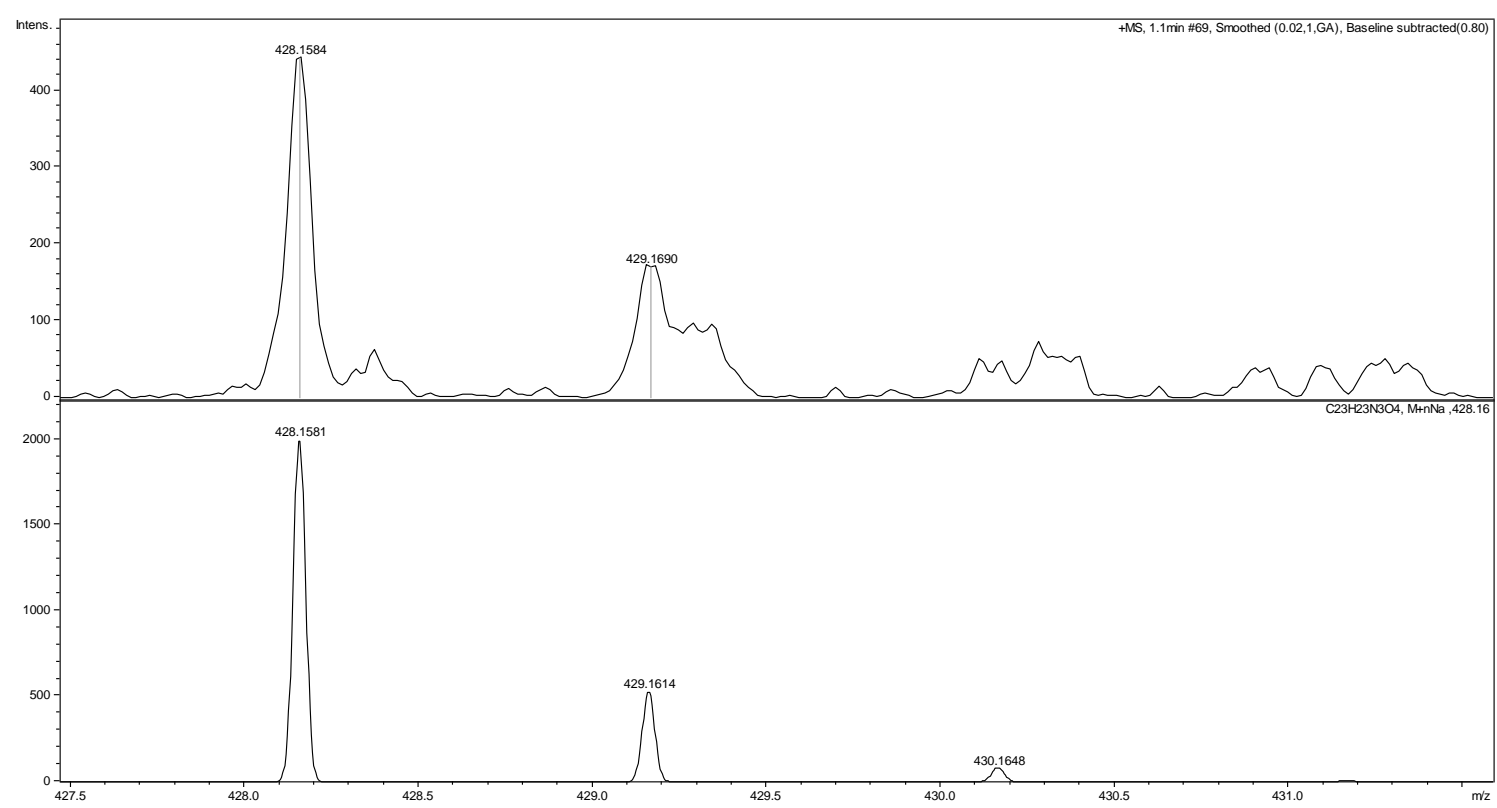

Figure S81. High resolution mass spectrum of S5 (HRMS, ESI-TOF, top: experimental, bottom: simulated).

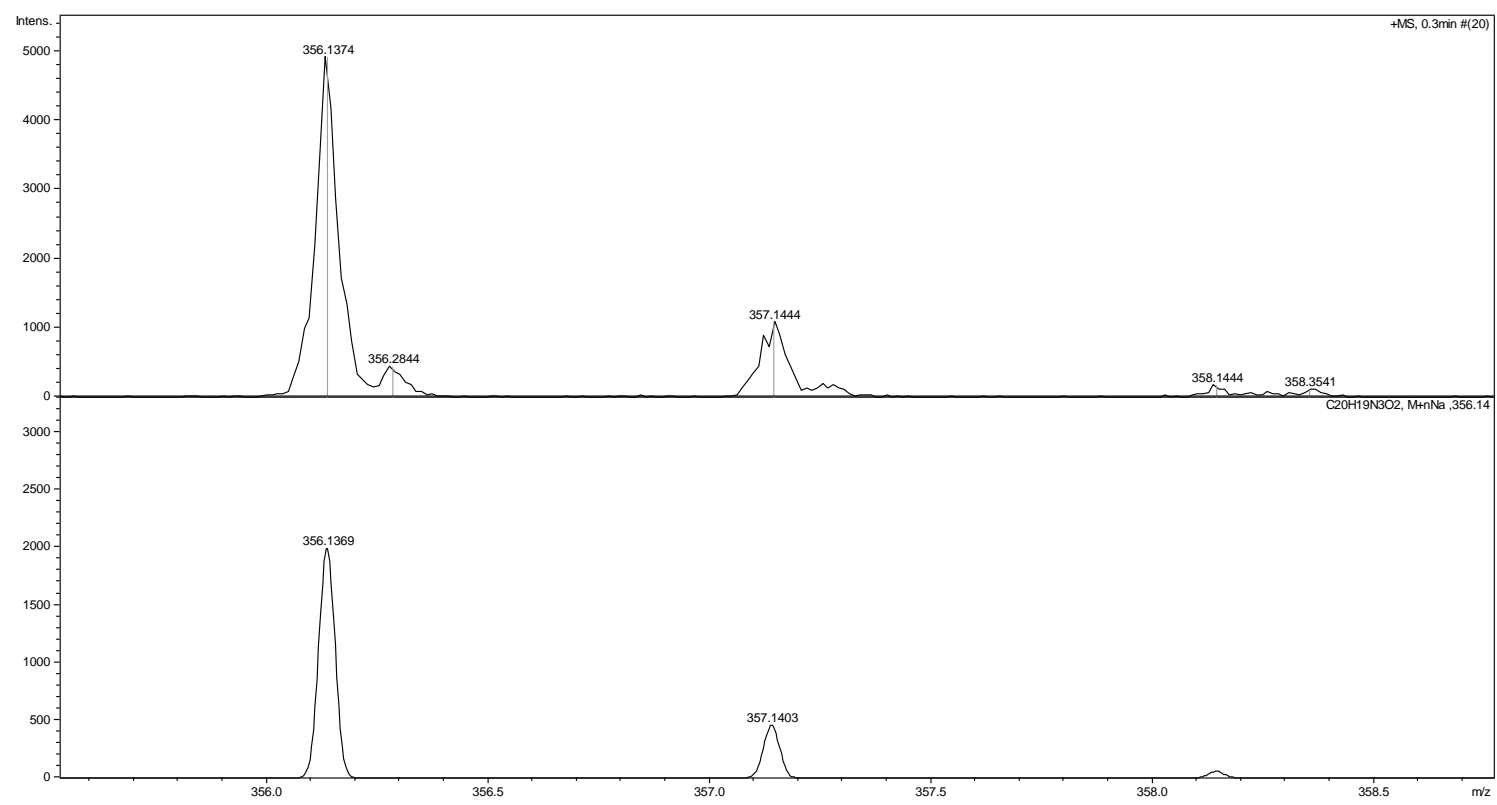

Figure S82. High resolution mass spectrum of $\mathbf{2}$ (HRMS, ESI-TOF, top: experimental, bottom: simulated). 


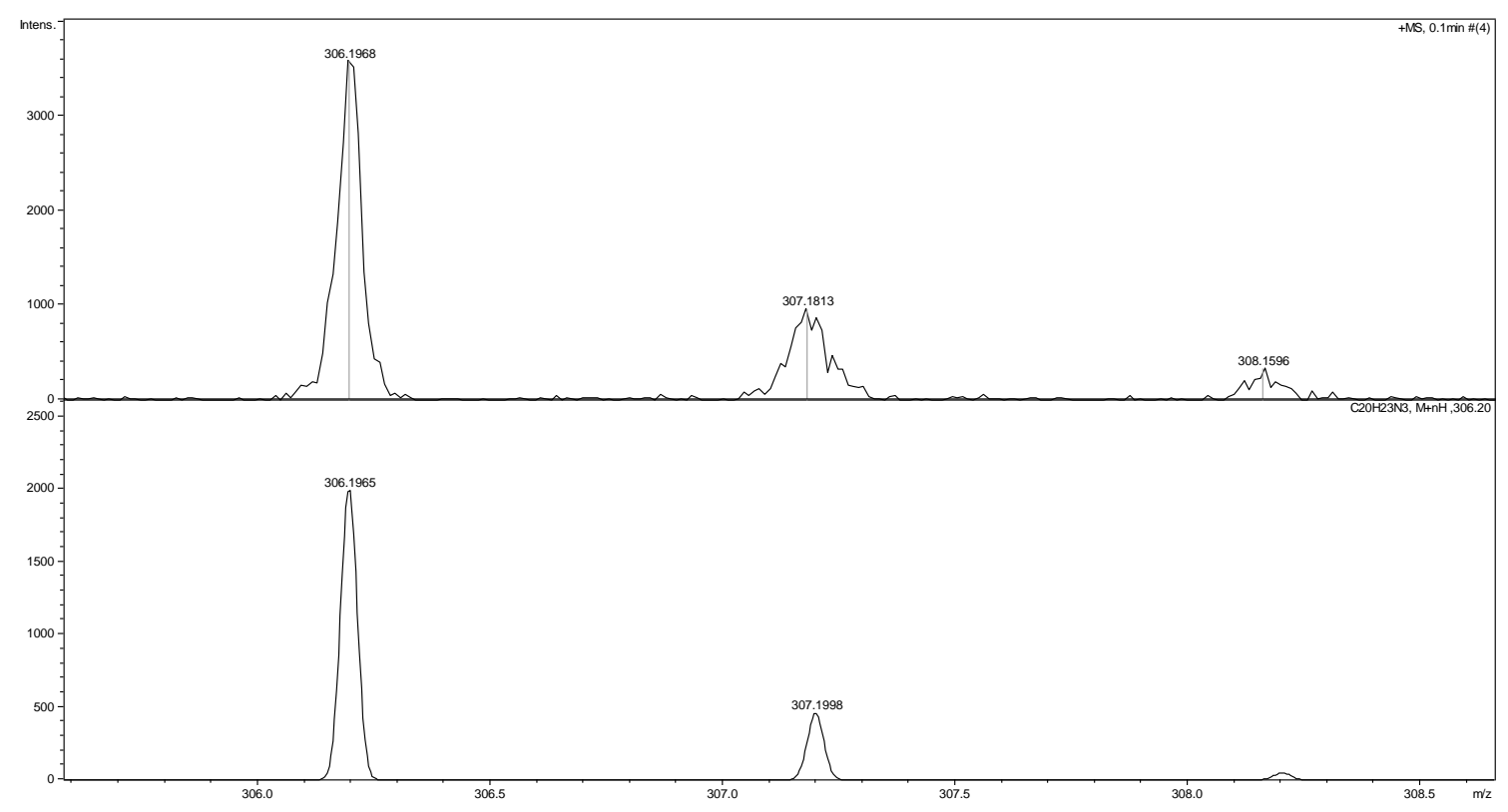

Figure S83. High resolution mass spectrum of 1 (HRMS, ESI-TOF, top: experimental, bottom: simulated).

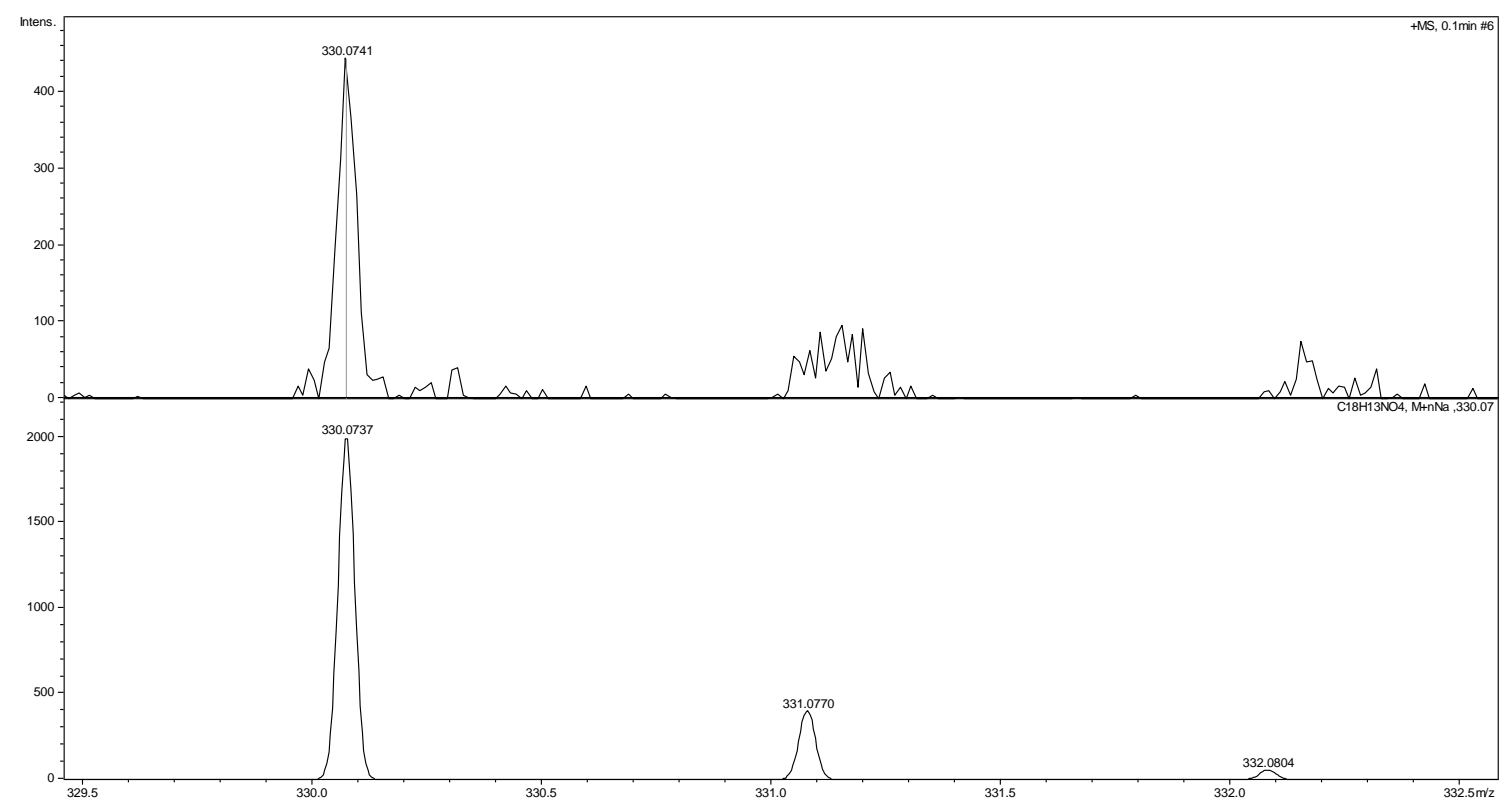

Figure S84. High resolution mass spectrum of $\mathbf{3}$ (HRMS, ESI-TOF, top: experimental, bottom: simulated). 


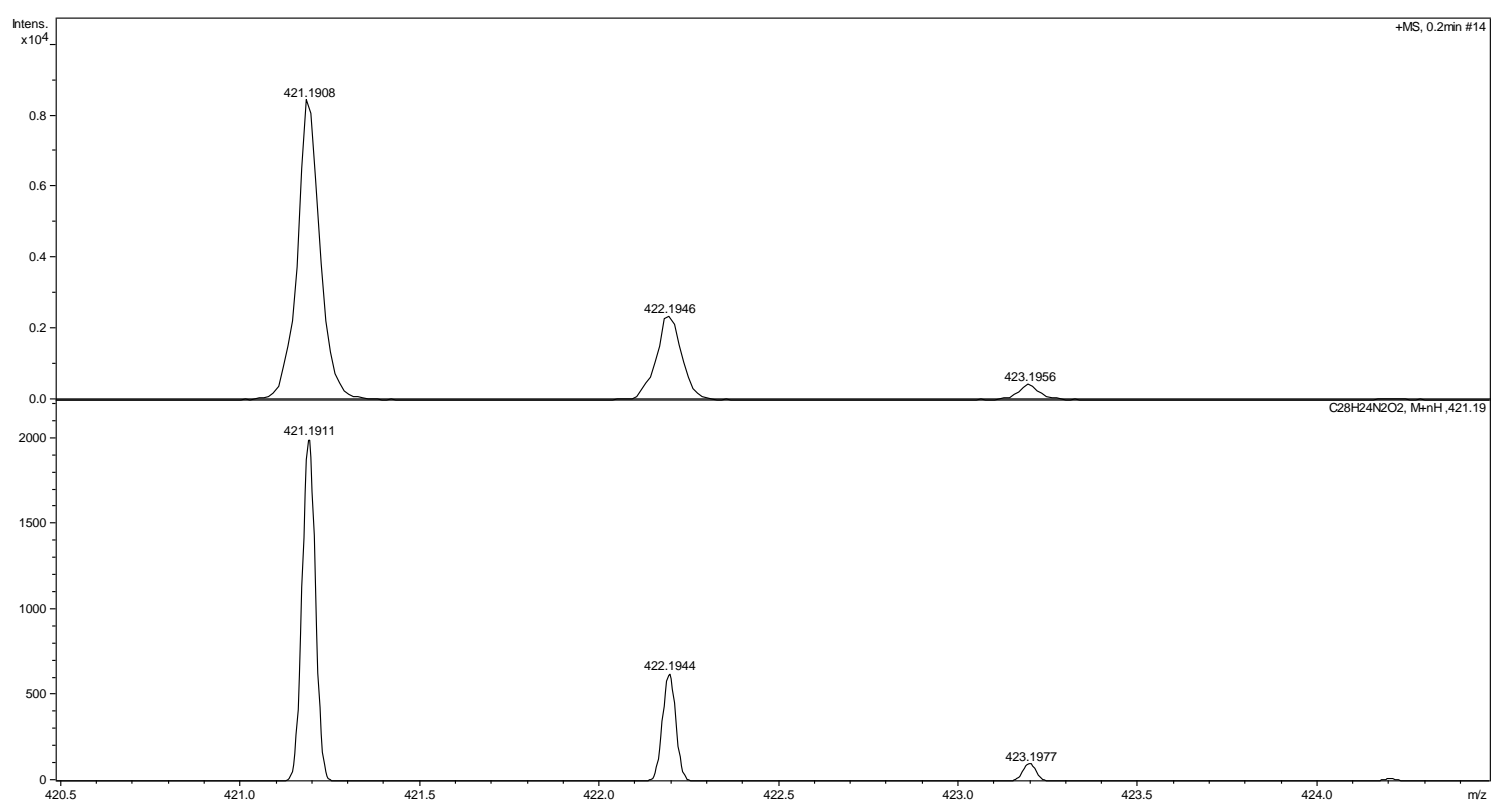

Figure S85. High resolution mass spectrum of 4 (HRMS, ESI-TOF, top: experimental, bottom: simulated).

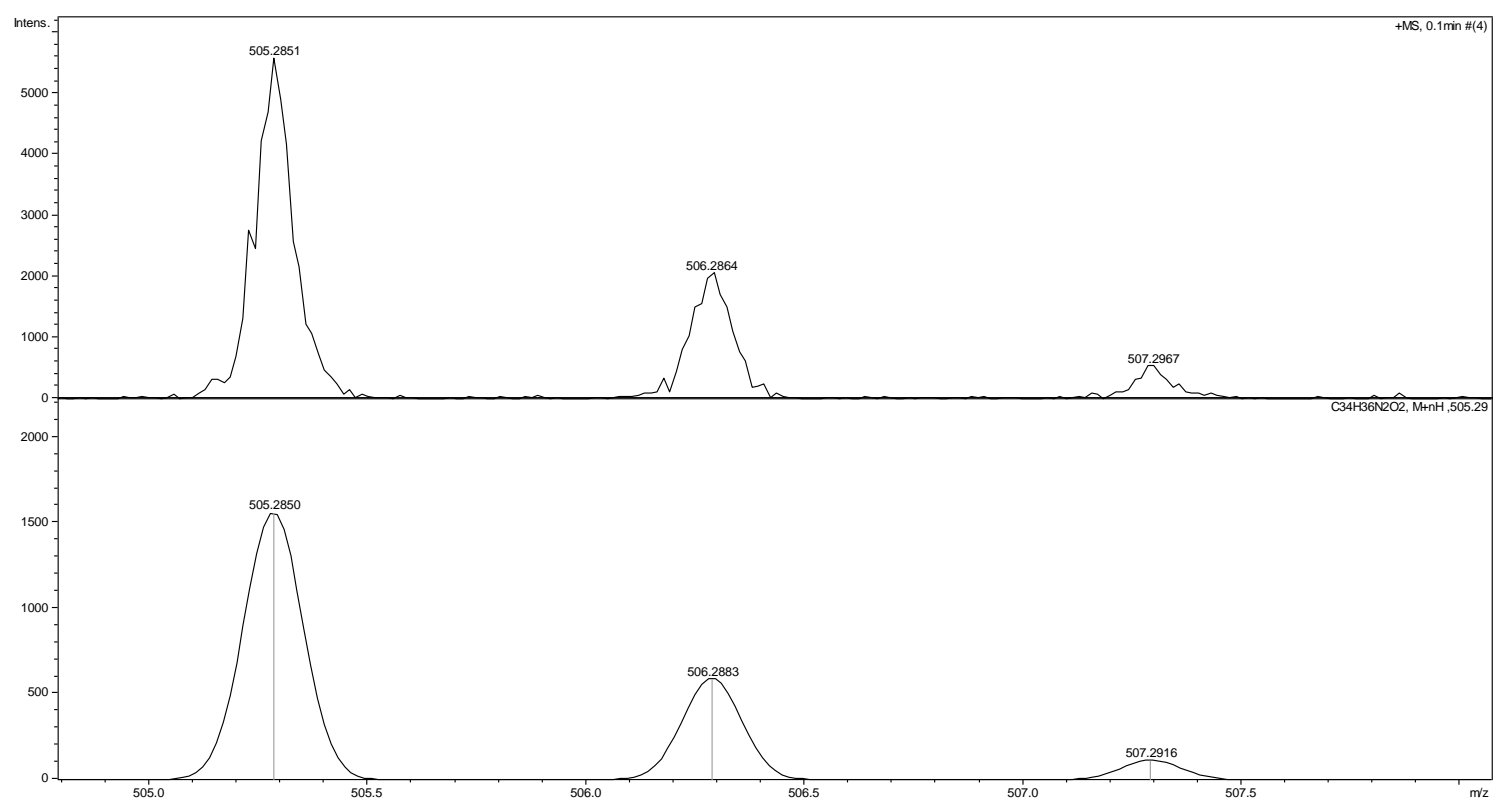

Figure S86. High resolution mass spectrum of 4' (HRMS, ESI-TOF, top: experimental, bottom: simulated). 


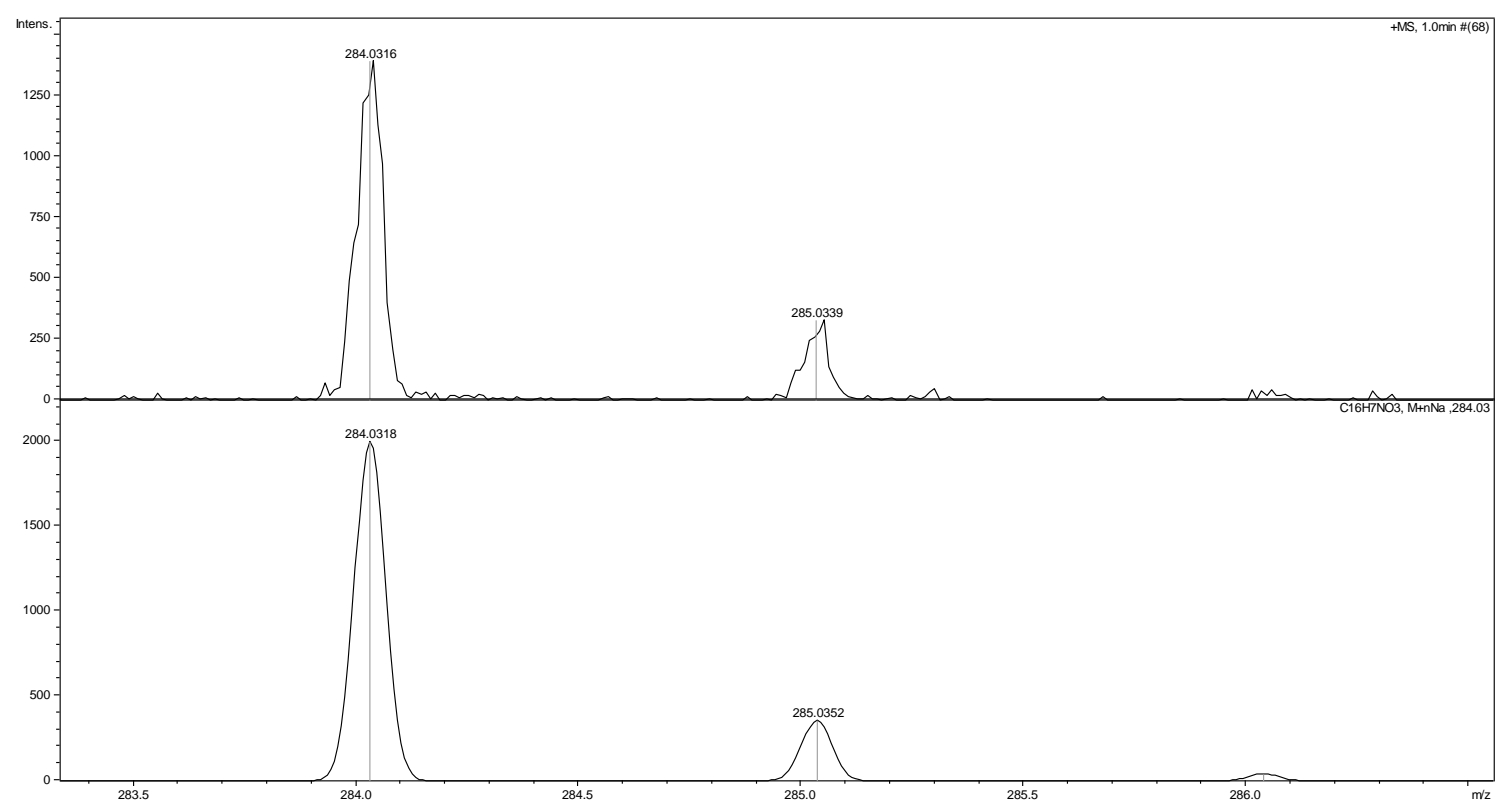

Figure S87. High resolution mass spectrum of 5 (HRMS, ESI-TOF, top: experimental, bottom: simulated).

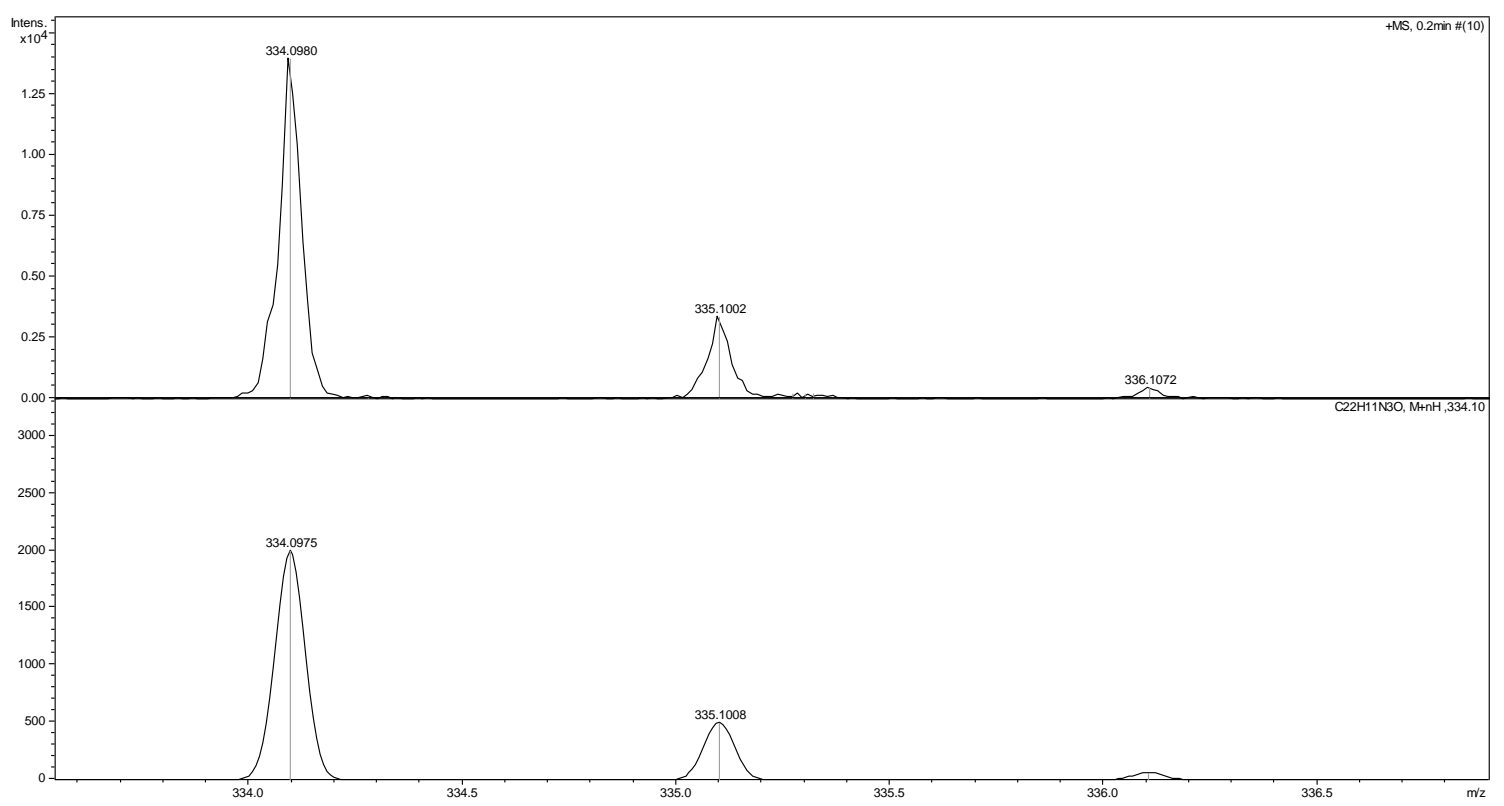

Figure S88. High resolution mass spectrum of 6 (HRMS, ESI-TOF, top: experimental, bottom: simulated). 


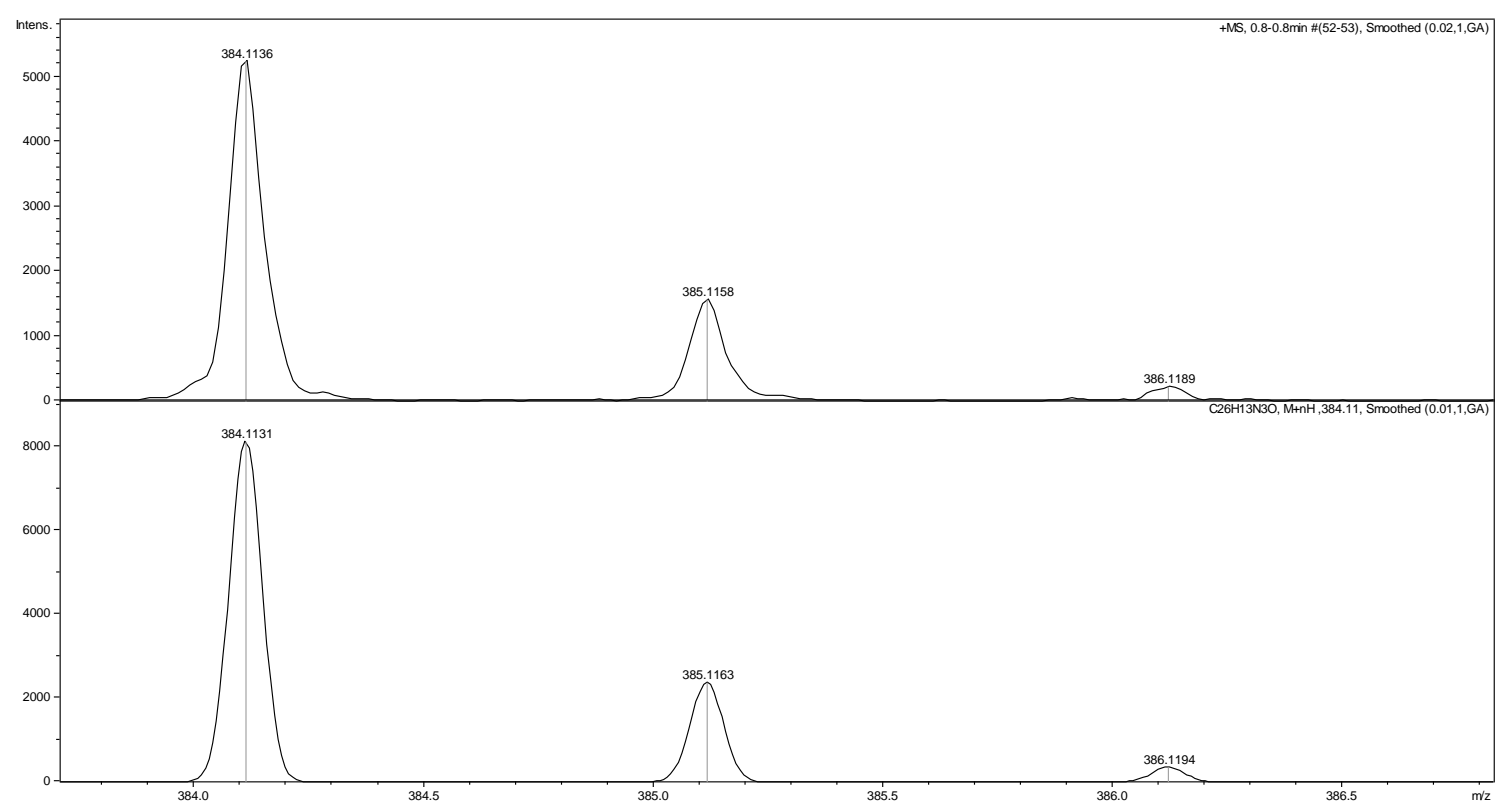

Figure S89. High resolution mass spectrum of 7 (HRMS, ESI-TOF, top: experimental, bottom: simulated).

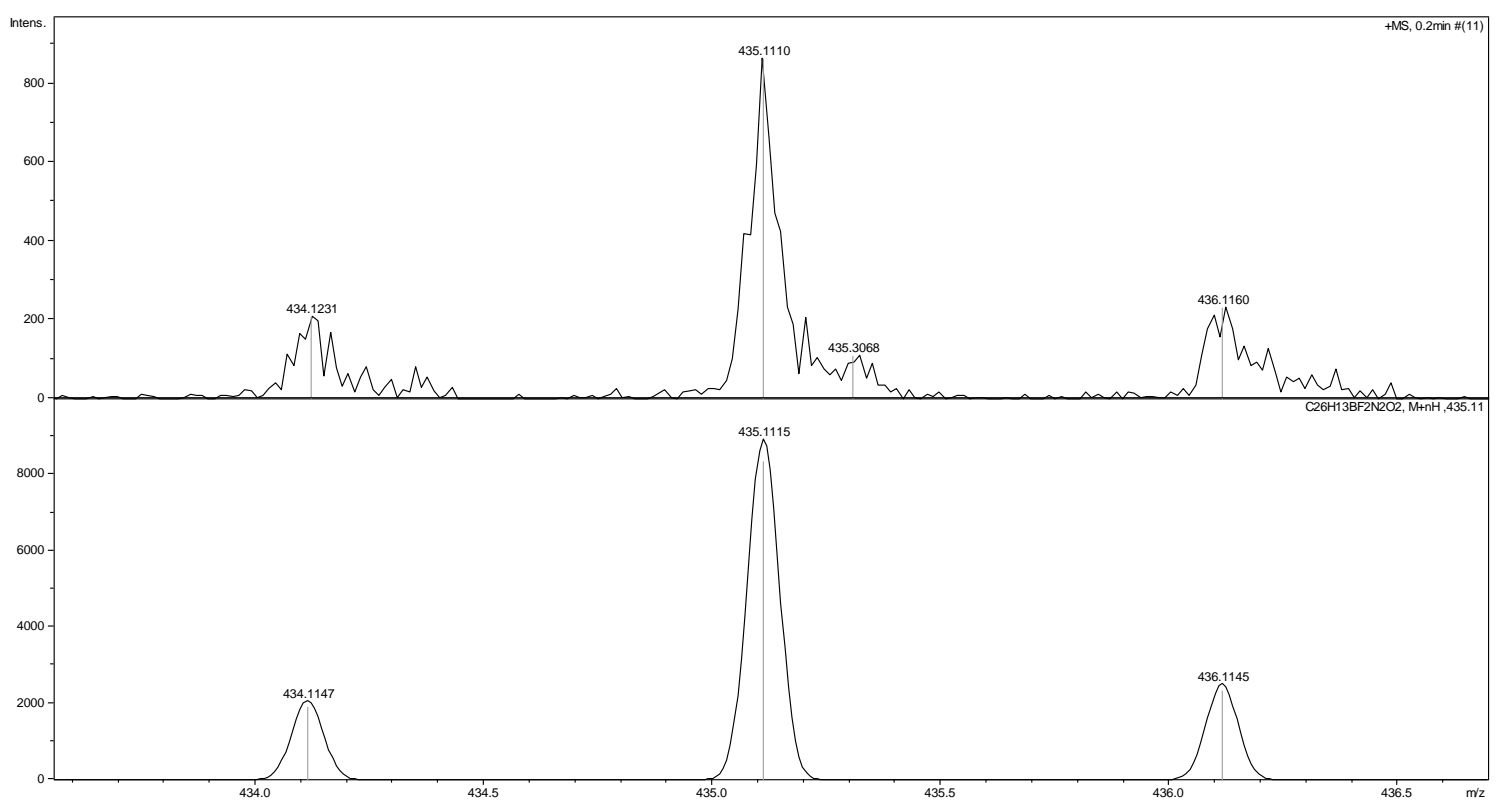

Figure S90. High resolution mass spectrum of 8 (HRMS, ESI-TOF, top: experimental, bottom: simulated). 


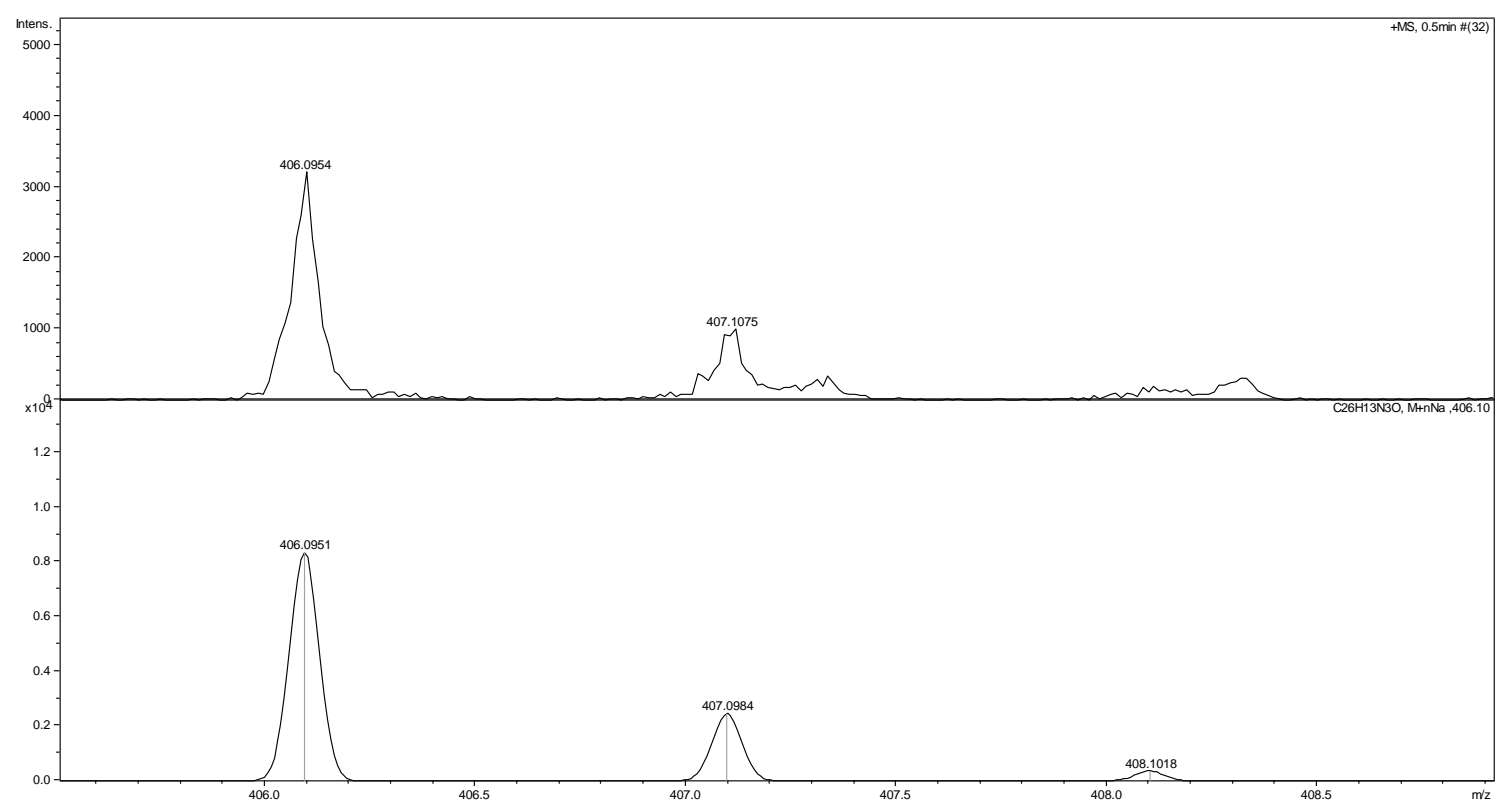

Figure S91. High resolution mass spectrum of 9 (HRMS, ESI-TOF, top: experimental, bottom: simulated).

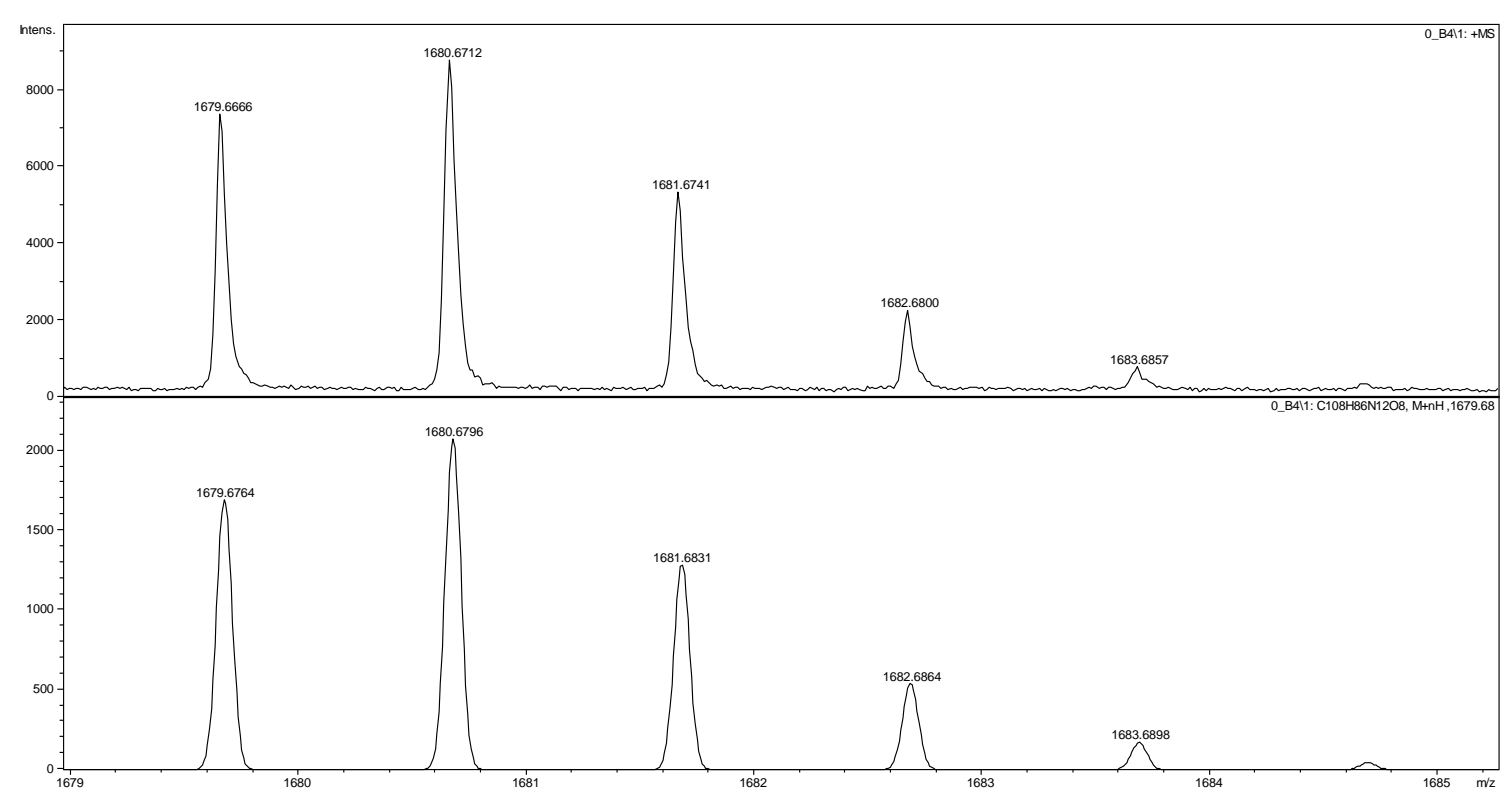

Figure S92. High resolution mass spectrum of $\mathbf{1 0}-\mathrm{H}_{\mathbf{2}}$ (HRMS, MALDI-TOF, top: experimental, bottom: simulated). 


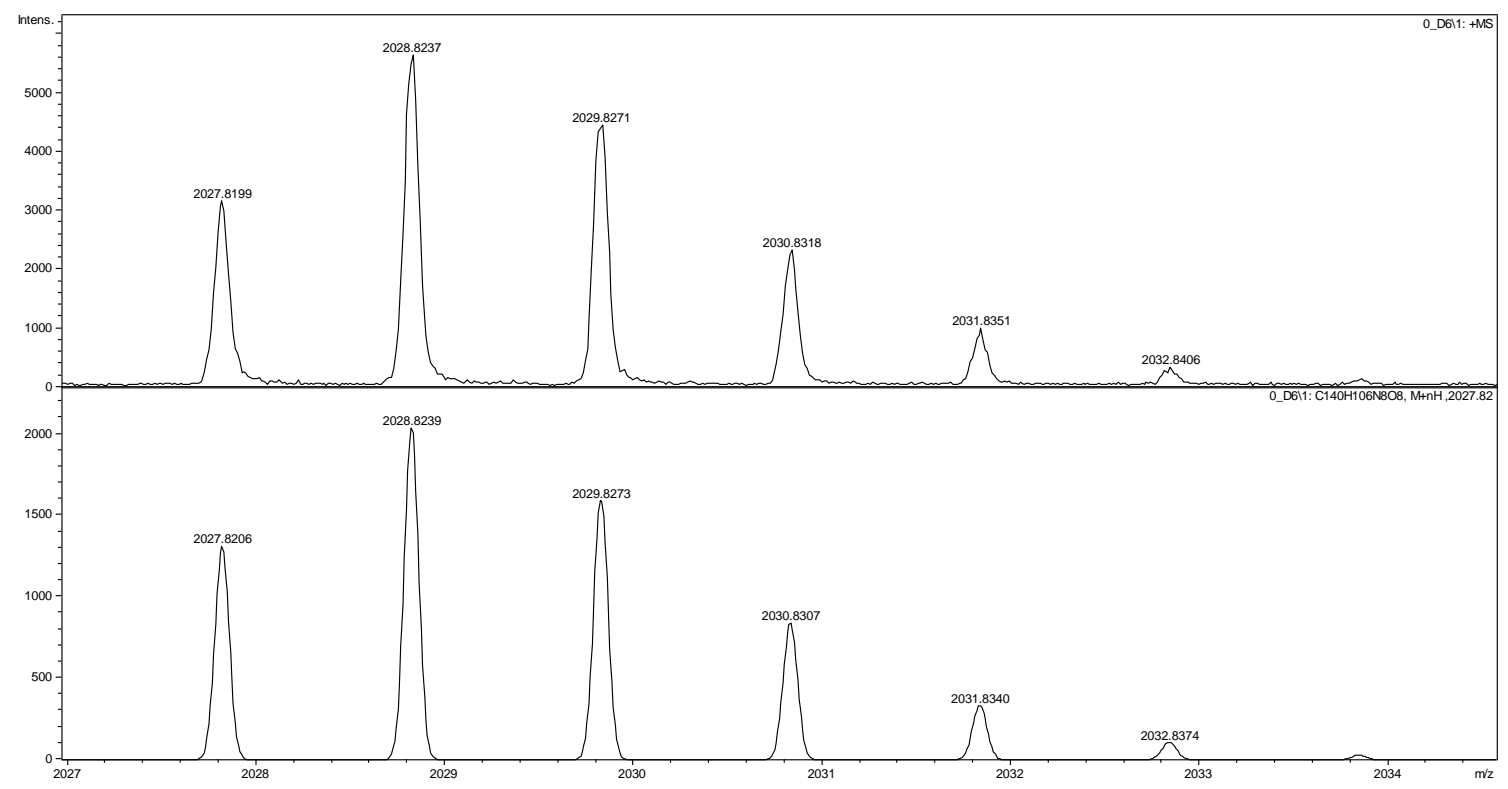

Figure S93. High resolution mass spectrum of $\mathbf{1 1 - H _ { 2 }}$ (HRMS, MALDI-TOF, top: experimental, bottom: simulated).

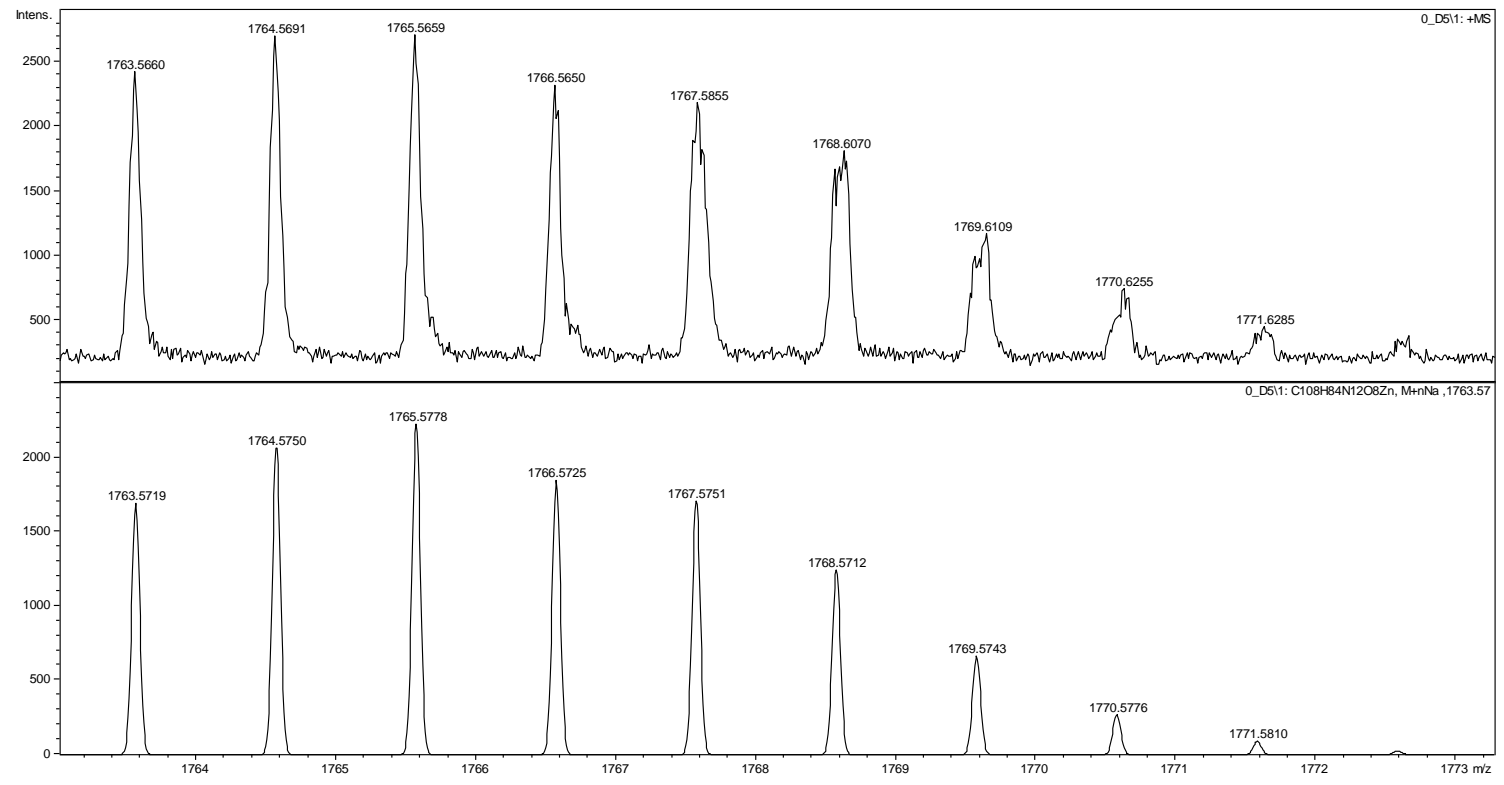

Figure S94. High resolution mass spectrum of 10-Zn (HRMS, MALDI-TOF, top: experimental, bottom: simulated). 


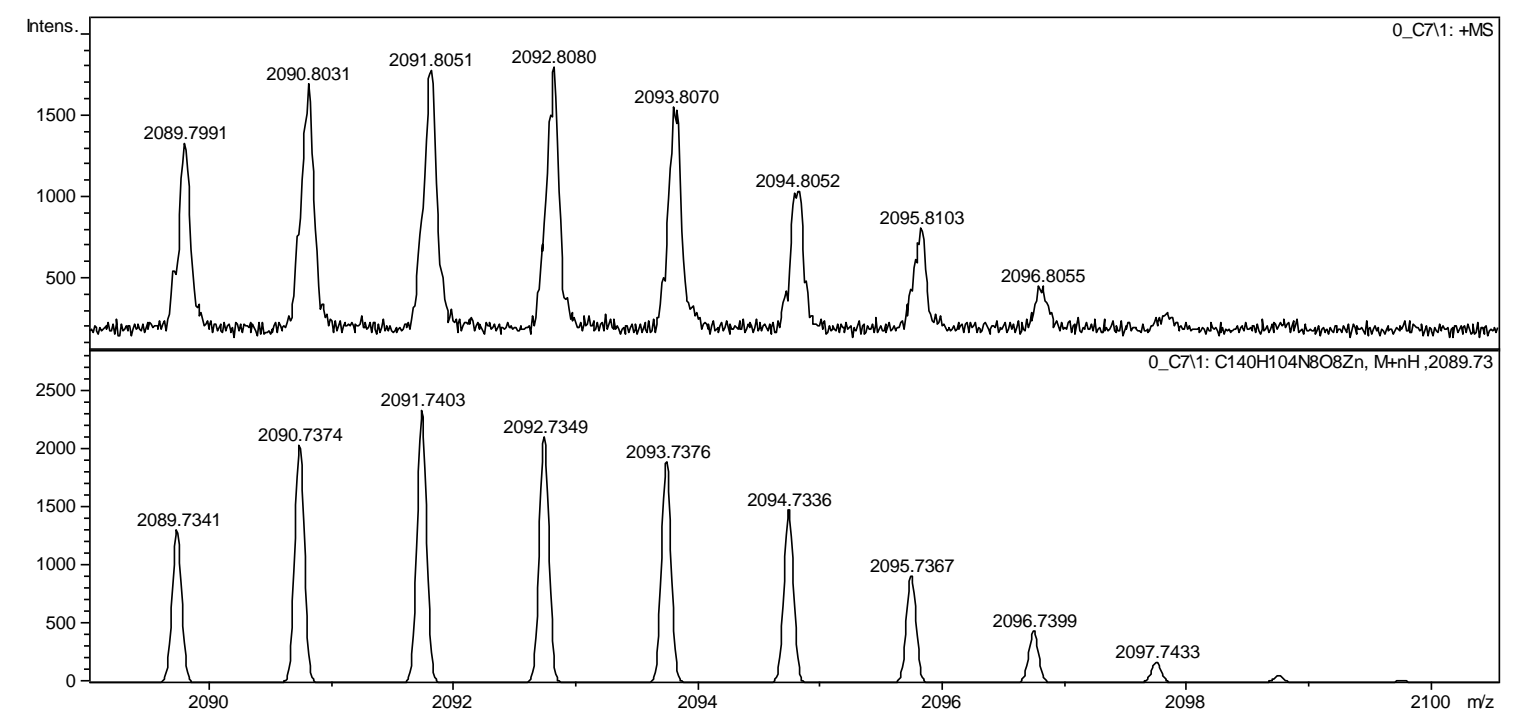

Figure S95. High resolution mass spectrum of 11-Zn (HRMS, MALDI-TOF, top: experimental, bottom: simulated).

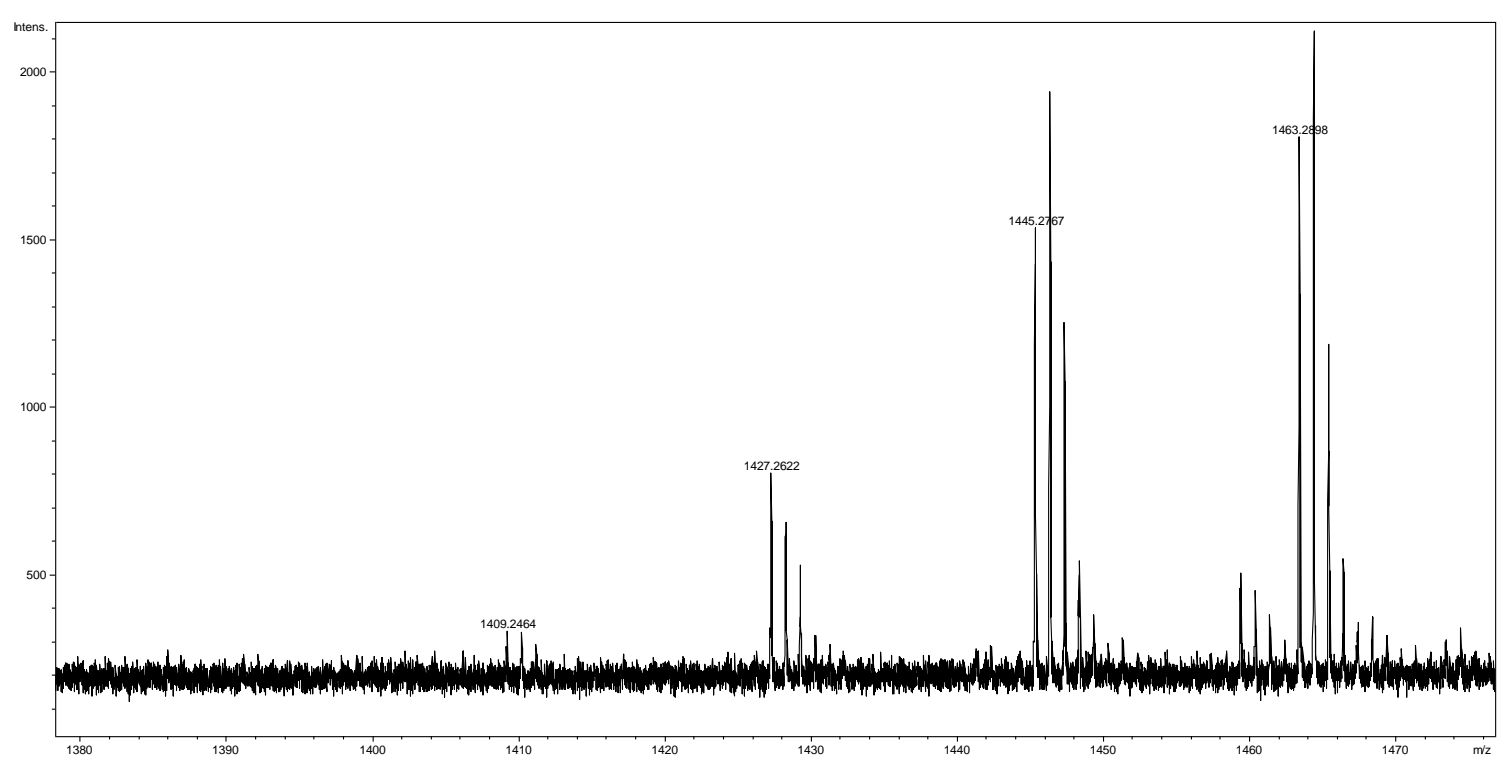

Figure S96. High resolution mass spectrum of S6 (HRMS, MALDI-TOF, complete region of interest). 


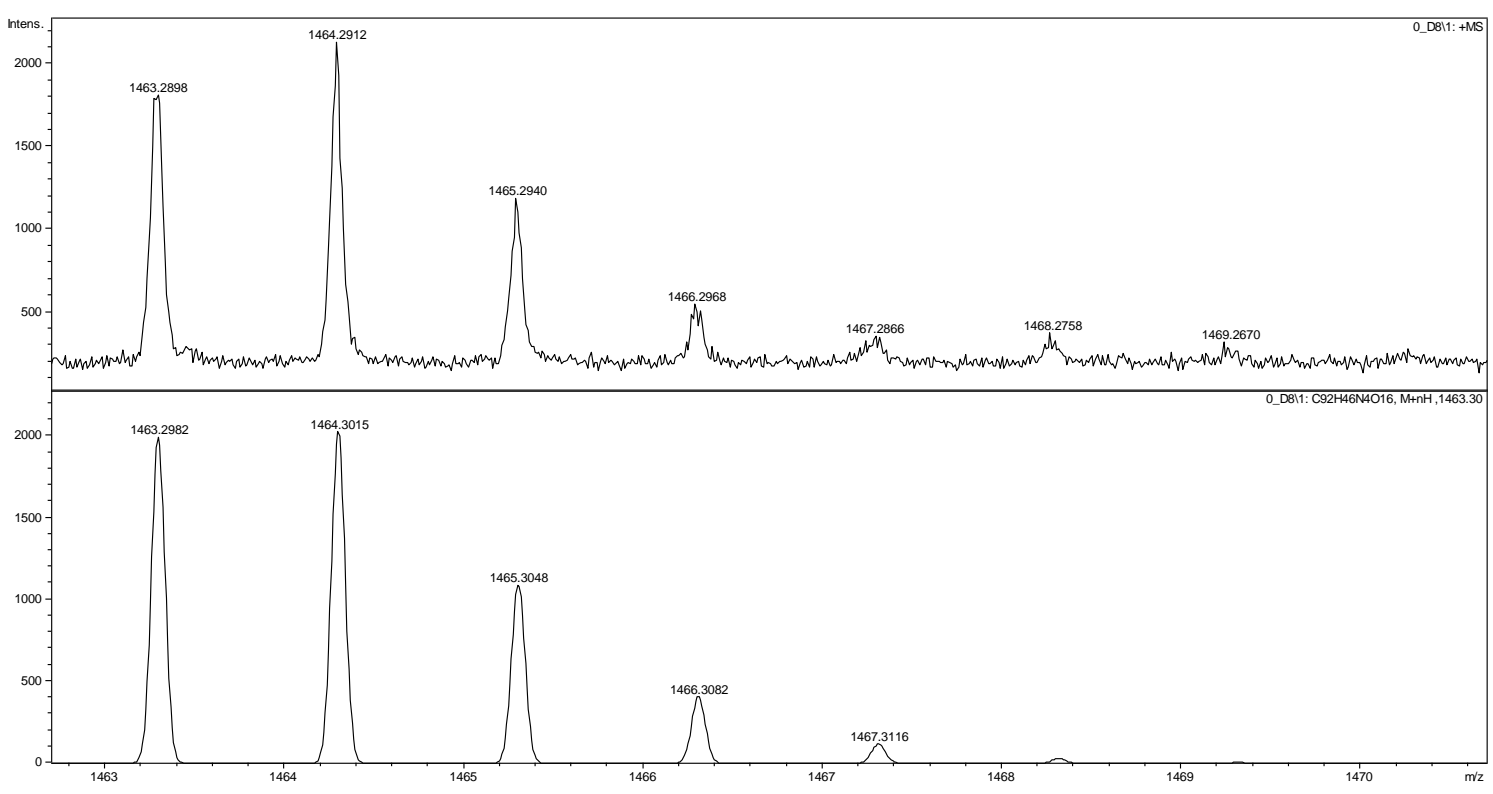

Figure S97. High resolution mass spectrum of S6 (HRMS, MALDI-TOF, top: experimental, bottom: simulated). 


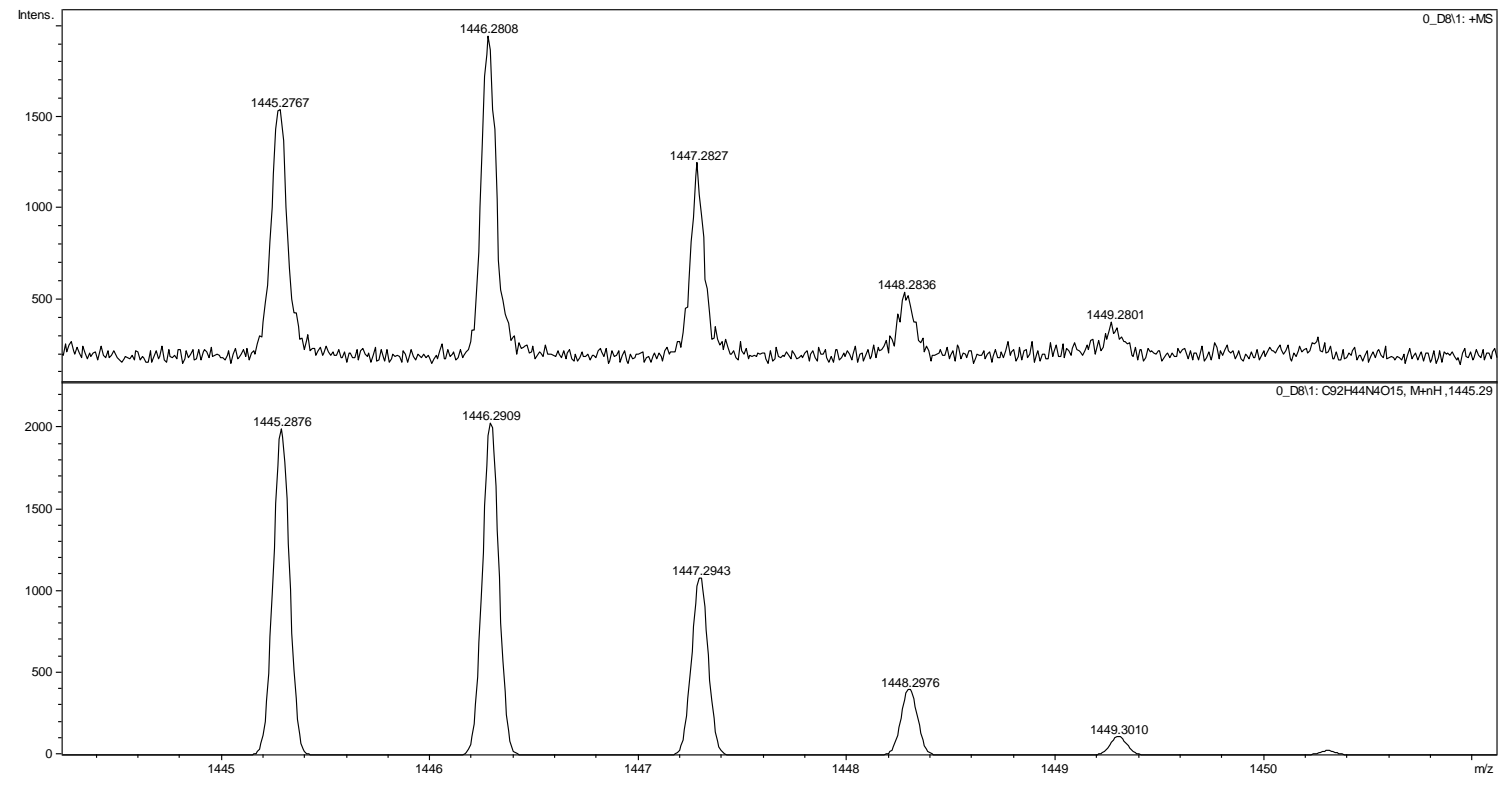

Figure S98. High resolution mass spectrum of S6- $\mathrm{H}_{2} \mathrm{O}$ (HRMS, MALDI-TOF, top: experimental, bottom: simulated).

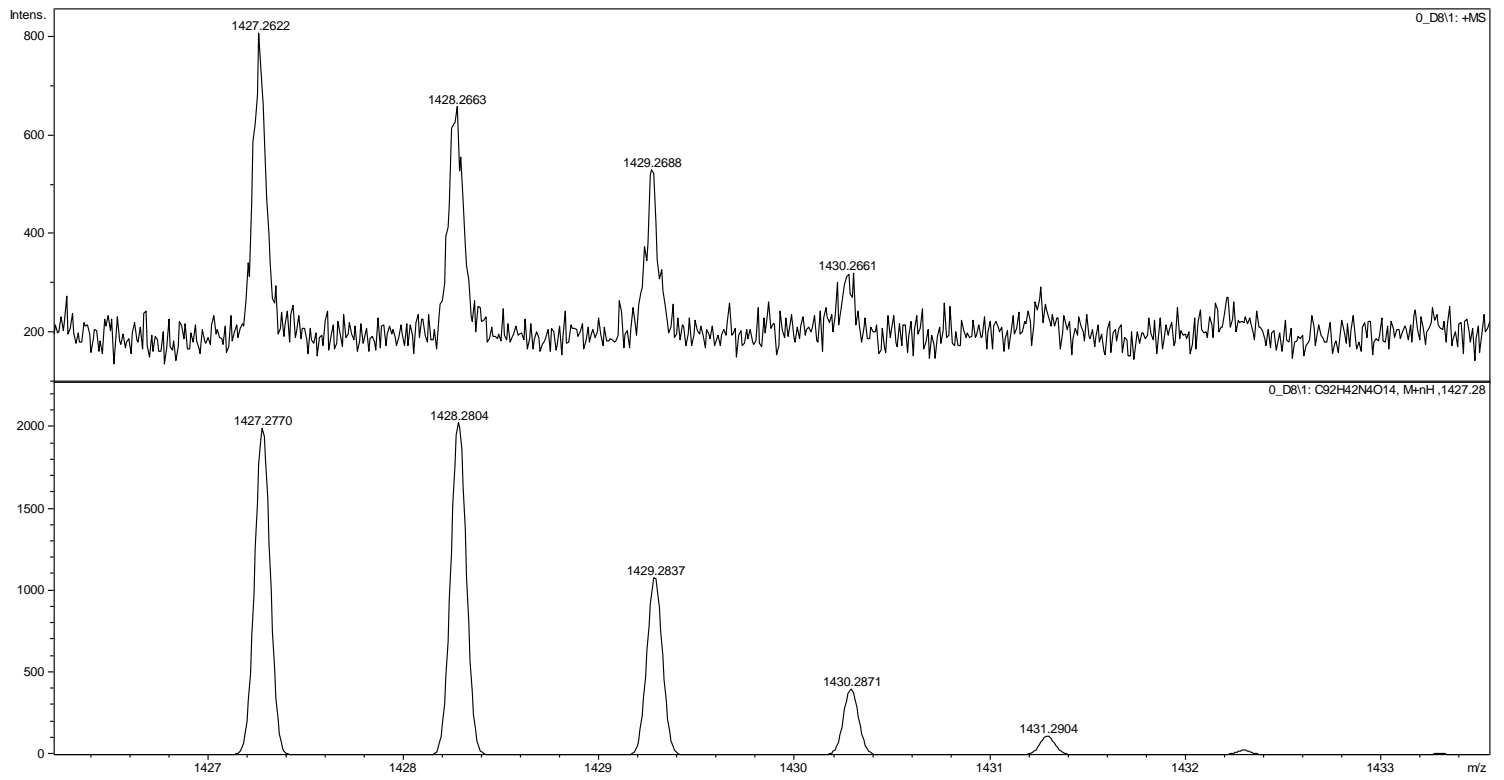

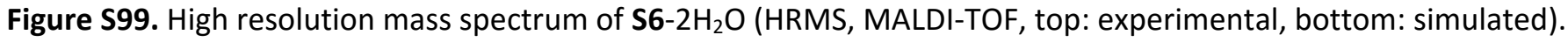




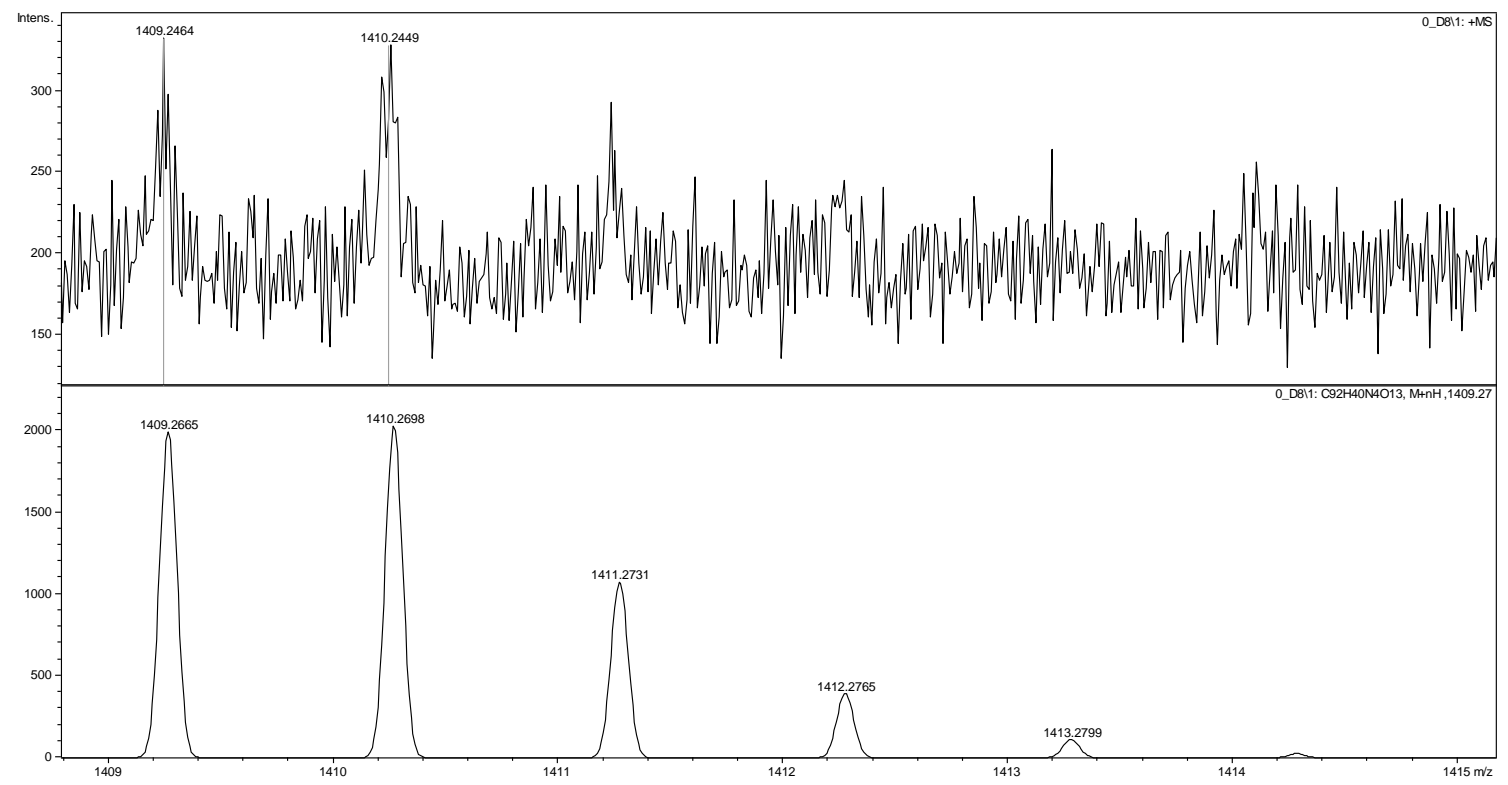

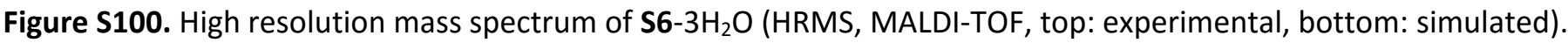


References 
(1) Frisch, M. J.; Trucks, G. W.; Schlegel, H. B.; Scuseria, G. E.; Robb, M. A.; Cheeseman, J. R.; Scalmani, G.; Barone, V.; Mennucci, B.; Petersson, G. A.; Nakatsuji, H.; Caricato, M.; Li, X.; Hratchian, H. P.; Izmaylov, A. F.; Bloino, J.; Zheng, G.; Sonnenberg, J. L.; Hada, M.; Ehara, M.; Toyota, K.; Fukuda, R.; Hasegawa, J.; Ishida, M.; Nakajima, T.; Honda, Y.; Kitao, O.; Nakai, H.; Vreven, T.; Montgomery, Jr., J. A.; Peralta, J. E.; Ogliaro, F.; Bearpark, M.; Heyd, J. J.; Brothers, E.; Kudin, K. N.; Staroverov, V. N.; Kobayashi, R.; Normand, J.; Raghavachari, K.; Rendell, A.; Burant, J. C.; Iyengar, S. S.; Tomasi, J.; Cossi, M.; Rega, N.; Millam, J. M.; Klene, M.; Knox, J. E.; Cross, J. B.; Bakken, V.; Adamo, C.; Jaramillo, J.; Gomperts, R.; Stratmann, R. E.; Yazyev, O.; Austin, A. J.; Cammi, R.; Pomelli, C.; Ochterski, J. W.; Martin, R. L.; Morokuma, K.; Zakrzewski, V. G.; Voth, G. A.; Salvador, P.; Dannenberg, J. J.; Dapprich, S.; Daniels, A. D.; Farkas, Ö.; Foresman, J. B.; Ortiz, J. V.; Cioslowski, J.; Fox, D. J. Gaussian 09 Revision E.01; Gaussian Inc.: Wallingford CT, 2009.

(2) Becke, A. D. Phys. Rev. A 1988, 38, 3098-3100.

(3) Becke, A. D. J. Chem. Phys. 1993, 98, 5648-5652.

(4) Lee, C.; Yang, W.; Parr, R. G. Phys. Rev. B 1988, 37, 785-789.

(5) Tomasi, J.; Mennucci, B.; Cammi, R. Chem. Rev. 2005, 105, 2999-3094.

(6) Hirata, S.; Head-Gordon, M. Chem. Phys. Lett. 1999, 314, 291-299.

(7) Chen, Z.; Wannere, C. S.; Corminboeuf, C.; Puchta, R.; Schleyer, P. von R. Chem. Rev. 2005, 105, 3842-3888.

(8) Stanger, A. J. Org. Chem. 2006, 71, 883-893.

(9) Zhao, Y.; Truhlar, D. G. Theor. Chem. Acc. 2007, 120, 215-241.

(10) Jr, T. H. D. J. Chem. Phys. 1989, 90, 1007-1023.

(11) Kendall, R. A.; Jr, T. H. D.; Harrison, R. J. J. Chem. Phys. 1992, 96, 6796-6806.

(12) Woon, D. E.; Jr, T. H. D. J. Chem. Phys. 1993, 98, 1358-1371.

(13) Marenich, A. V.; Cramer, C. J.; Truhlar, D. G. J. Phys. Chem. B 2009, 113, 6378-6396.

(14) Marenich, A. V.; Ho, J.; Coote, M. L.; Cramer, C. J.; Truhlar, D. G. Phys. Chem. Chem. Phys. 2014, 16, 15068-15106.

(15) Reed, A. E.; Weinstock, R. B.; Weinhold, F. J. Chem. Phys. 1985, 83, 735-746.

(16) Sheldrick, G. M. Acta Crystallogr. A 2008, 64, 112-122.

(17) Spackman, M. A.; Jayatilaka, D. CrystEngComm 2009, 11, 19-32.

(18) Turner, M. J.; McKinnon, J. J.; Jayatilaka, D.; Spackman, M. A. CrystEngComm 2011, 13, 1804-1813.

(19) Barattin, R.; Gourdon, A. Eur. J. Org. Chem. 2009, 2009, 1022-1026.

(20) Anderson, A. G.; Anderson, R. G. J. Am. Chem. Soc. 1955, 77, 6610-6611.

(21) Zhen, Y.; Tanaka, H.; Harano, K.; Okada, S.; Matsuo, Y.; Nakamura, E. J. Am. Chem. Soc. 2015, 137, 2247-2252.

(22) Feng, J.; Liang, B.; Wang, D.; Xue, L.; Li, X. Org. Lett. 2008, 10, 4437-4440.

(23) Newberry, R. W.; VanVeller, B.; Guzei, I. A.; Raines, R. T. J. Am. Chem. Soc. 2013, 135, 7843-7846. 